\author{
UNIVERSIDADE DE SÃO PAULO \\ FACULDADE DE FILOSOFIA, LETRAS E CIÊNCIAS HUMANAS \\ DEPARTAMENTO DE TEORIA LITERÁRIA E LITERATURA COMPARADA \\ PROGRAMA DE PÓS-GRADUAÇÃO EM \\ TEORIA LITERÁRIA E LITERATURA COMPARADA
}

\title{
Rubem Fonseca na França
}

MARIA CLÁUDIA RODRIGUES ALVES

São Paulo

2006 


\author{
UNIVERSIDADE DE SÃO PAULO \\ FACULDADE DE FILOSOFIA, LETRAS E CIÊNCIAS HUMANAS \\ DEPARTAMENTO DE TEORIA LITERÁRIA E LITERATURA COMPARADA \\ PROGRAMA DE PÓS-GRADUAÇÃO EM \\ TEORIA LITERÁRIA E LITERATURA COMPARADA
}

\title{
Rubem Fonseca na França
}

MARIA CLÁUDIA RODRIGUES ALVES

Tese apresentada ao programa de PósGraduação em Teoria Literária e Literatura Comparada da Faculdade de Filosofia, Letras e Ciências Humanas da Universidade de São Paulo, para obtenção do título de Doutor em Letras.

Orientadora: Profa. Dra. SANDRA MARGARIDA NITRINI

\section{São Paulo}

2006 
A minha mãe, sempre querida. A meu pai, com saudades. 


\section{Agradecimentos}

Agradeço a atenção, o tempo e o empenho de meus familiares, professores, amigos, colegas e novos conhecidos que aceitaram consagrar tempo e energia à coleta de dados, ao intercâmbio de informações e de idéias, contribuindo para a realização deste trabalho.

A Isabela, Lílian, Magda, Maria Teresa, Walderez, Hugo e Rosana, por seus conhecimentos em língua estrangeira comigo compartilhados. A Eli e Ana Lúcia, pelo apoio e carinho, sempre. A Márcia Aguiar, em especial.

A Beatriz Turquety, Diva Damato, Eduardo Coutinho, Elaine Cristina Prado dos Santos, Elisa Guimarães, Mário Laranjeira, Maria Helena Fioravante Peixoto, Maria Luiza Guarnieri Atik, Marisa Lajolo, Pierre Rivas, pelo entusiasmo face ao tema e pelo fluxo de idéias.

A Bruno Clément, Célia Guimarães Helene, Celso e Wilton Azevedo, Emiliana Bonalumi, Halumi Takahashi (CenDoTec), Raquel Botelho, Ricardo Lima, Sébastien Roy, Sérgio Jones Mendonça, pelo apoio na coleta de material de pesquisa.

A Daisy Elísio Deonísio da Silva, Daniel Pigeon, Daniel W. Graham, Estela dos Santos Abreu, Florent Kohler, Jean Jonassaint, Jean-Claude Vignol, Lyne Strouc, Marguerite Wünscher, Philippe Billé, Philippe Simon e Philippe Sohiez, pela simpática acolhida e pelos testemunhos.

A Helena Bonito Couto Pereira, Marilei Jorge, Nelson Luís Barbosa, pessoas especiais, profissionais cujos destinos estão inevitavelmente ligados ao meu, pelo amparo e pelas críticas, essenciais ao meu crescimento.

Aos funcionários do Departamento de Teoria Literária e Literatura Comparada da Faculdade de Fislosofia, Letras e Ciências Humanas, representados pelo competente Luiz, agradeço a constante amabilidade.

À Banca de Qualificação, Prof. Dr. Francis Henrik Aubert e Prof. Dr. Alain Mouzat, manifesto meu franco reconhecimento pela atenção e pelos oportunos conselhos.

Meus agradecimentos, ainda e sempre, especiais e sinceros, à Profa. Dra. Sandra Margarida Nitrini, por sua sabedoria, conhecimentos e orientação. 


\section{Resumo}

A tradução de uma obra literária a introduz em um novo contexto lingüístico e cultural, renovando os diálogos entre as sociedades. As opções dos tradutores na solução de problemas de ordem lingüístico e cultural, as opções dos editores quanto ao formato e à aparência do objeto livro oferecido ao grande público, o teor das críticas dos especialistas são indicadores da maneira pela qual uma cultura se apropria da obra traduzida e revelam a imagem que sociedade receptora tem ou mantém da cultura de origem do texto original. A presente tese de doutorado procura analisar a recepção da obra traduzida de Rubem Fonseca na França por meio da interpretação de material textual e paratextual, atentando para os diversos tipos de leitura realizados dessa obra até chegar ao leitor estrangeiro: leitura da crítica especializada, dos editores e dos tradutores, leitores privilegiados.

Palavras-chave: Rubem Fonseca, literatura comparada, tradução literária, recepção de literatura brasileira, relações Brasil-França. 


\begin{abstract}
The translation of a literary work introduces it into a new linguistic and cultural context, renewing the dialogues between the societies involved. Translators' choices for the solution of linguistic and cultural problems, publishers' options concerning the format and appearance of the book as an object offered to the general public, and the nature of specialists' critiques are indicators of the way the target-language culture appropriates the translated work and they reveal the image that the receiving society has or maintains of the source-language culture. The present Ph.D thesis aims at analyzing the reception of the translations of Rubem Fonsecas's work in France through the interpretation of textual and paratextual material, considering the different kinds of reading of the work before that of the foreign reader: readings by specialized critics, publishers and translators, these being considered privileged readers.
\end{abstract}

Keywords: Rubem Fonseca, comparative literature, literary translation, reception of Brazilian literature, Brazil-France relations. 


\section{Résumé}

La traduction d'une œuvre littéraire l'introduit dans un nouveau contexte, tout en renouvelant les dialogues entre les sociétés concernées. Les choix des traducteurs face aux problèmes d'ordre linguistique ou culturel, les choix des éditeurs quant au format et à l'apparence du livre comme objet, destiné au grand public, le contenu des critiques des spécialistes sont autant d'indicateurs de la manière dont une culture s'approprie l'œuvre traduite et révèlent quelle image la société réceptrice se fait ou perpétue de la culture d'origine du texte de l'auteur. La présente thèse de doctorat aborde la réception de l'œuvre traduite de Rubem Fonseca en France, en se fondant sur l'interprétation du matériel textuel et paratextuel et sur l'étude des différents types de lectures qui ont été faites de cette œuvre avant d'arriver entre les mains du lecteur étranger : lecture de la critique spécialisée, des éditeurs et des traducteurs, lecteurs privilégiés.

Mots-clés: Rubem Fonseca, littérature comparée, traduction littéraire, réception de la littérature brésilienne en France, relations Brésil-France. 


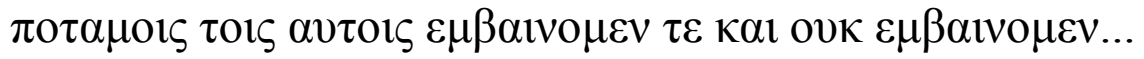
in idem flumen bis descendimus et non descendimus... On ne se baigne jamais deux fois
dans le meme fleuve... Ninguém se banha duas vezes nas águas do mesmo rio...

(Heráclito) 


\section{Sumário}

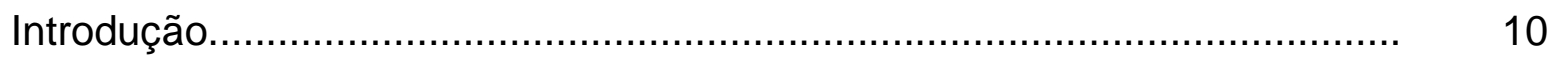

I. Da recepção à imagem da literatura brasileira na França................. 16

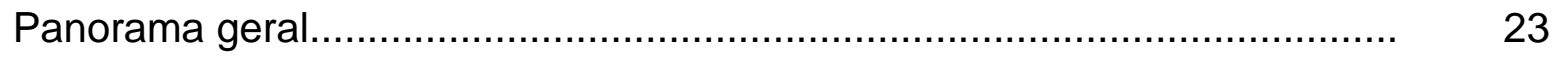

Em destaque: a fortuna crítica de Rubem Fonseca..................................... 31

Revue Europe: imagem do Brasil em três momentos.................................. 55

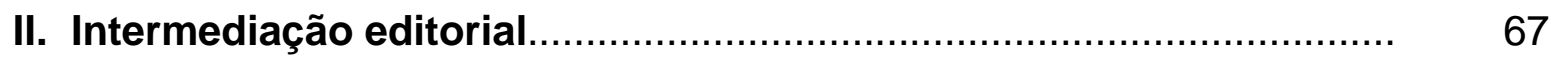

Capas, contracapas e entornos de antologias............................................. 68

Capas, contracapas e entornos de livros................................................... 79

III. Alguns livros por dentro............................................................ 107

As marcas sociais e culturais nas traduções da pioneira Marguerite

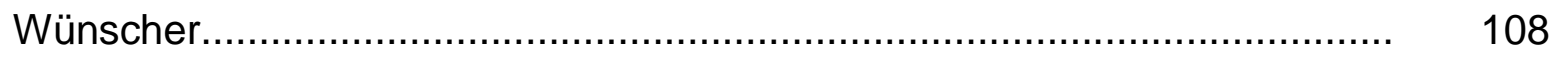

As marcas sociais e culturais nas traduções em antologias e coletâneas.... 132

Soluções apresentadas por Rubem Fonseca ao tradutor Philippe Billé (correspondência inédita) ................................................................. 140

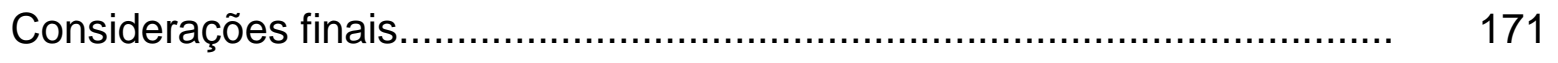

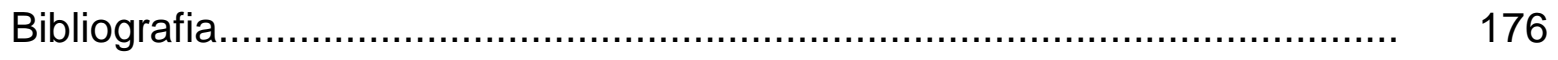

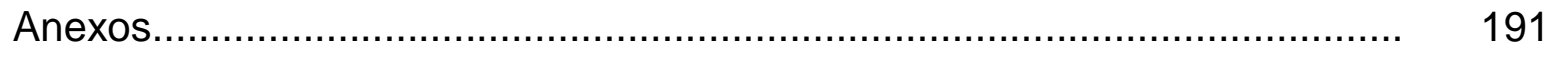




\section{Introdução}

A literatura brasileira, na busca de sua identidade, desde sempre encontrou suas fontes, seus modelos em literaturas centrais, notadamente na francesa. Muitos estudos comprovam o interesse dos pesquisadores em explicar as motivações dessa afinidade.

As relações entre o Brasil e a França vêm sendo objeto de estudo de pesquisadores há diversas gerações. No domínio da literatura comparada, vislumbram-se inúmeras formas de abordar o assunto: por meio da presença flagrante (por citação explícita ou referência) ou sutil (revelando uma afinidade, um diálogo) de um escritor francês na obra de um escritor brasileiro; pelas traduções de obras francesas para a língua portuguesa do Brasil; pelos escritos paraliterários, como ensaios e artigos publicados na mídia brasileira nos dois últimos séculos.

São excelentes estudos, todos imbuídos dos preceitos do professor Antonio Candido (1993, p.211), que já afirmava por volta dos anos 1950: "estudar literatura brasileira é estudar literatura comparada".

Esses trabalham privilegiam uma parte do todo: um período, um gênero, um autor; e trilham o caminho mais evidente das relações de influência (sobretudo do centro para a periferia) e o diálogo entre a França e o Brasil. São, entretanto, em sua maioria, estudos de "mão única", porque a maior parte deles olha para a presença francesa no Brasil.

Por uma questão quantitativa que muitas vezes nos remete à dialética centro/periferia, conseqüentemente à questão qualitativa, raramente se examina 0 impacto de um escritor brasileiro em relação à literatura francesa. Pode-se muito brevemente listar os resultados mais recentes desse tipo de pesquisa.

Estela dos Santos Abreu $(1990,2004)$ realiza há vários anos o levantamento das obras brasileiras traduzidas na França. As sucessivas edições 
demonstram que se trata de um instrumento de trabalho essencial aos estudiosos do diálogo franco-brasileiro.

Alguns estudos acadêmicos também contemplaram esse vértice, como a tese de doutorado L'oeuvre de Jorge Amado en France: enquête sur les traductions de ses oeuvres et les réactions de la critique, de Maria Thereza Indiani de Oliveira (1977), em Grenoble, que versa sobre a recepção de Jorge Amado na França.

Pesquisas desenvolvidas na Katholieke Universiteit van Leuven - Bélgica, sobretudo sob a orientação do professor José Lambert, sondam questões de tradução de obras brasileiras para a língua francesa. Por exemplo, em 1980, o mestrado do pesquisador Walter Costa: Un roman brésilien en français. Questions de traduction à propos de Grande Sertão: Veredas de J. Guimarães Rosa.

Mais recentemente, Marie-Hélène Catherine Torres (2004), também orientanda do professor José Lambert, brinda os leitores com a publicação de um profundo estudo de recepção de literatura brasileira na França, resultado de seu doutorado (defendido em 2001), que contempla um século, de 1890 a 1990, e em especial o autor José de Alencar: Variations sur l'étranger dans les lettres: cent ans de traductions françaises des lettres brésiliennes.

No Brasil, destacam-se a dissertação de mestrado, de 1982, Duas traduções francesas de Memórias póstumas de Brás Cubas: por uma estilística da tradução, sob a orientação de Nina Atuko Mabuchi Miyaki, e a tese de doutorado, de 1991, Recepção da obra machadiana na França: um estudo critico-estilístico das traduções de quatro romances, de Lea Mara Valezi Staut, sob orientação de Ítalo Caroni. Gaby Friess Kirsch, sob a orientação de Sandra M. Nitrini defendeu em 1998 sua tese de doutoramento sobre a recepção de Osman Lins tanto na França quanto na Alemanha: Poética da tradução e recepção estética Nove, novena na França e na Alemanha. A dissertação de mestrado de Teresa Dias Carneiro da Cunha (1999), sob a orientação do professor Eduardo Coutinho, versa sobre As obras de Mário de Andrade traduzidas na França: história, concepção e crítica. 
Este é, pois, um campo de pesquisa bastante recente, e embora muito pesquisadores já tenham se debruçado sobre ele, permanece pouco explorado.

Ao mesmo tempo que os estudos de tradução em geral vêm se tornando cada vez mais autônomos em suas diferentes perspectivas de trabalho e metodologia de pesquisa, tornam-se também mais interdisciplinares. Não se trata de discutir a traduzibilidade ou intraduzibilidade dos textos. O processo de pesquisa da recepção de um autor traduzido em língua estrangeira envolve sobretudo estudos relativos ao texto em si, no original e em sua tradução, mas também outros elementos que participam de sua vida como texto: "os ângulos de observação são múltiplos: examina-se a obra traduzida mas também a literatura a que pertence (a sua fonte) e a literatura que vai integrar. A ênfase recai não apenas no objeto recebido mas no sistema receptor" (Carvalhal, 1993, p.52).

Dessa forma, convém tratar o assunto sob diferentes ângulos, interrelacionando-os. Concebeu-se, desse modo, um estudo caracteristicamente descritivo, do qual emana uma série de apreciações e reflexões, oriundas da simpatia de diversas teorias, como a Teoria da recepção de Jauss e Iser, preceitos da teoria da tradução elaborados por Schleiermacher e desenvolvidos por Venuti, que contrapõem a tradução assimiladora/domesticadora à tradução estrangeirizante; porém, cabe salientar que esta empreitada não tem a pretensão de generalizar ou definir procedimentos estanques, chegando a conclusões estáticas, mas sim convidar ao debate sadio e ao posicionamento crítico.

Elegeu-se para a realização deste estudo um autor contemporâneo cuja obra vem sendo traduzida para a língua francesa nas últimas décadas com certa regularidade: Rubem Fonseca, considerado um dos mais consagrados autores brasileiros vivos. Outro elemento bastante instigante que influenciou essa escolha foi o fato de sua obra, no Brasil, ter sempre sido recepcionada de forma polêmica e controvertida. Rubem Fonseca é um autor cuja obra tem sido conhecida em diversos países pelas traduções não somente para línguas de grande e médio alcance, como o inglês, o francês, o espanhol, o alemão, como também para o sueco ou o checo, só para citar algumas. 
Parte do corpus deste estudo nasceu da leitura de Feliz ano novo de Rubem Fonseca, inicialmente em língua portuguesa e, em seguida, de Bonne et heureuse année, a primeira tradução de um livro do autor para a língua francesa. As primeiras reflexões sobre o assunto foram apresentadas em Colóquio organizado pelo DTLLC da FFLCH em outubro de 2001 e no Congresso da ABRALIC de 2002. A partir do cotejo dos textos e da constatação de certas particularidades do ato tradutório, surgiu o desejo de ampliar o corpus para discutir aspectos relevantes da tradução e recepção da obra fonsequiana no estrangeiro.

Procurou-se, num primeiro momento, abranger a totalidade da obra fonsequiana traduzida para a língua francesa. Inúmeros colaboradores, tanto na França quanto no Canadá, contribuíram nessa tarefa. Verificou-se recentemente, no entanto, a existência de alguns contos traduzidos que, por falta de acesso, não constam do corpus deste trabalho. O próprio Rubem Fonseca, consultado informalmente, declarou não ter conhecimento de muitas das traduções de seus textos publicadas no exterior. Dessa forma, procedeu-se ao primeiro recorte, a saber, a delimitação espacial: o corpus compreende parte dos contos e a totalidade dos romances traduzidos e publicados na França.

Questionou-se, a partir do estabelecimento do corpus, se as traduções dos textos para a língua francesa mantêm o impacto provocado pelas obras em língua portuguesa, se os aspectos lingüísticos e sociolingüísticos são adequadamente traduzidos ou mantidos e em que medida as opções dos tradutores de Rubem Fonseca revelam (ou não), comprometem (ou não) o contexto sociocultural, o momento histórico-político da cultura de partida e de chegada. O cotejo e a análise de parte da obra traduzida, assim como a análise de parte da correspondência entre Rubem Fonseca e um de seus tradutores, Philippe Billé, apontam para a forma pela qual os tradutores, leitores privilegiados, não somente leram e transmitiram a obra fonsequiana, mas revelam igualmente seu posicionamento enquanto mediadores de uma imagem do Brasil na França. Nesse sentido, sondou-se o universo do tradutor, sua relação com a literatura em geral, com o Brasil e com a literatura brasileira, conduzindo a pesquisa à apreciação de material extraliterário. 
O foco deste trabalho, voltado para a recepção de Rubem Fonseca na França, requer um primeiro breve momento de reflexão sobre a literatura como sistema e o mercado literário. Para tanto, lança-se mão do conceito de literatura estabelecido por Antonio Candido em diálogo com as concepções sociomercadológicas de Robert Escarpit, abrindo assim o Capítulo I deste trabalho. Um panorama analítico sobre as relações entre o Brasil e França, o interesse dos franceses pela literatura brasileira e o perfil do mercado editorial francês são elementos básicos indispensáveis para contextualizar a obra traduzida de Rubem Fonseca nesse país e adentrar sua fortuna crítica, também nesse capítulo.

No Capítulo II, a intenção é apreciar o material paratextual francês, no que Genette denominou o peritexto das obras traduzidas: capas, contracapas, orelhas e terceiras páginas e textos das publicações, e eventualmente, quando possível, instanciais prefaciais. Pode-se, conseqüentemente, refletir de que maneira elementos extraliterários colaboraram com as expectativas dos leitores potenciais da obra fonsequiana e em que medida esse material revela os projetos editoriais e uma certa forma de apresentar o Brasil, o autor brasileiro e sua obra, na França.

O Capítulo III aborda o material textual de três formas distintas: a) procedendo ao cotejo entre parte da obra original e as traduções francesas, a saber, o volume compreendendo Feliz ano novo e O caso Morel, traduzidos por Marguerite Wüscher em 1982; b) análise temática dos contos publicados em revistas especializadas e/ou antologias de contos; c) apresentação e análise da correspondência entre Rubem Fonseca e o tradutor dos romances para a língua francesa, Philippe Billé. Os três enfoques visam apreciar tanto algumas opções dos tradutores quanto os projetos editorias nos quais se inserem os textos.

As considerações finais não têm a pretensão de ser definitivas e conclusivas. Buscam, ao contrário, abrir a discussão para a dificuldade em se compreender o papel da literatura brasileira no exterior, quando se pretende sair do exotismo regional ou pseudo-ideológico e adentrar a espinhosa questão dos elementos que participam do atual mercado editorial. 
Dessa forma, este trabalho pretende contribuir para os estudos de Literatura relativos às relações Brasil-França, refletindo sobre as condições de recepção de Rubem Fonseca no contexto francês e verificando a hipótese de que perscrutar a recepção de Rubem Fonseca na França, por meio da análise de material textual e extratextual de literatura traduzida, pode possibilitar uma melhor compreensão de seu lugar não somente no sistema literário francês e/ou brasileiro, mas em um sistema mais universalizante, que é, consciente ou inconscientemente, o objetivo de toda literatura. 


\section{Da recepção à imagem da literatura brasileira na França}

Au début, c'était comme ça: aimer imaginer (rêver, inventer des idées, fabuler) m'a amené à aimer lire. Aimer lire m'a amené, encore adolescent, à aimer écrire, c'est-à-dire, m'a donné envie de créer ce que j'admirais.

Très vite, j'ai découvert qu'écrire est parfois ennuyeux, parfois exaspérant, et presque toujours fatigant.

Qu'est-ce qui m'a fait persévérer? D'une certaine façon la même chose qui fait que le charpentier continue à être charpentier. II est difficile d'arrêter de faire un travail dont l'apprentissage a exigé tant de temps et d'effort.

(Fonseca, 1985, p.25)

Este é um depoimento bastante sucinto que Rubem Fonseca concedeu à publicação francesa Libération, respondendo à questão de uma sondagem, em 1985: "Pourquoi écrivez-vous?". Quatrocentos escritores responderam à mesma questão de forma mais prolixa ou, mais raramente, de modo mais conciso que Fonseca. Depoimento sucinto e raro, pois o leitor de Rubem Fonseca está mais habituado a ler a opinião das personagens fonsequianas a respeito do ofício de escrever e da função do escritor, do que a do próprio autor, discreto, avesso a entrevistas.

É o que ocorre, por exemplo, no conto "Intestino grosso":

Telefonei para o Autor, marcando uma entrevista. Ele disse que sim, desde que fosse pago - "por palavra". Eu respondi que não estava em condições de decidir, teria primeiro de falar com o Editor da revista. (Fonseca: 1999a, p.163)

\footnotetext{
1 "No começo era assim: gostar de imaginar (sonhar, inventar idéias, fabular) me levou a gostar de ler. Gostar de ler me levou, ainda adolescente, a gostar de escrever, ou seja, me deu vontade de criar o que eu admirava.

Muito rapidamente, descobri que escrever é às vezes entediante, às vezes exasperador, e quase sempre cansativo.

O que me fez perseverar? De certa maneira, o mesmo que faz com que o carpinteiro continue a ser carpinteiro. É difícil parar de fazer um trabalho cuja aprendizagem exigiu tanto tempo e esforço." Todas as traduções apresentadas são minhas.
} 
A entrevista concedida pelo personagem "Autor" ao narrador do conto oscila entre declarações absurdas e hilárias e considerações extremamente sérias sobre a literatura.

Em O caso Morel (Fonseca, 2003a), a reflexão acerca da criação ficcional é paralela à investigação policial contemplada no enredo, e aparece no diálogo interno do narrador personagem em diversas ocasiões:

Nada temos a temer. Exceto as palavras. (ibidem, p.11)

$\mathrm{O}$ verdadeiro escritor nada tem a dizer. Tem uma maneira de dizer nada. (ibidem, p.12)

A trama e a seqüência tradicionais não têm mais significação... o escritor tende a uma consciência mais aguda de si mesmo no ato de criar. $O$ exterior torna-se menor e o escritor afasta-se da realidade objetiva, afasta-se da história, da trama, do caráter definido, até que a percepção subjetiva do narrador é o único fato garantido na ficção. (ibidem, p.92)

Outros personagens de Fonseca estão inevitavelmente ligados ao ato de escrever, como o escritor Gustavo Flávio, pseudônimo de Ivan Canabrava em Bufo \& Spallanzani.

De certa forma, o escritor brasileiro que menos concede entrevistas é o que mais se desvenda em seus livros por meio de seus personagens. Se o ato de escrever é constantemente contemplado nas narrativas de Fonseca, o ato de ler, mesmo implicitamente, também o é. Quem escreve, escreve para ser lido. O escritor é essencialmente um leitor, intérprete do mundo, e traduz esse mundo no que escreve. Uma vez escrita, a obra se presta a diversas leituras por parte de seus leitores potenciais, mas o escritor, consciente ou inconscientemente, escreve para "um certo leitor", presente em sua imaginação. Dentre os leitores de uma obra em língua original, um se destaca, seja ele o futuro editor, o tradutor, ou simplesmente alguém que decida que a obra seja traduzida. Vale aqui salientar que, muitas vezes, esse leitor, sobre o qual recai a decisão da tradução e da edição em língua estrangeira, não está obrigatoriamente entre os leitores da obra original, mas pode ser informado por um leitor intermediário. 
As afirmações feitas pressupõem diversas teorias que têm como objeto a literatura, o escritor, o leitor e a tradução de literatura. Essas interfaces vão desde teorias presentes no campo da Lingüística, da Teoria Literária, da Literatura Comparada, da Estética da Recepção, da Teoria da Tradução, até preceitos das áreas de História, Sociologia etc. Cumpre aqui citar algumas das teorias que contemplam a literatura, o escritor e o leitor como objeto de estudo, e suas possíveis vertentes, para, em suas intersecções, situar as reflexões emergentes deste estudo.

Segundo Antonio Candido (1959), a literatura preacinde de um sistema que considere a tríade autor/obra/leitor. Para ele, literatura é:

um sistema de obras ligadas por denominadores comuns, que permitem reconhecer as notas dominantes duma fase. Estes denominadores são, além das características internas, (língua, temas, imagens), certos elementos de natureza social e psíquica, embora literariamente organizados, que se manifestam historicamente e fazem da literatura aspecto orgânico da civilização. Entre eles se distinguem: a existência de um conjunto de produtores literários, mais ou menos conscientes do seu papel; um conjunto de receptores, formando os diferentes tipos de público, sem os quais a obra não vive; um mecanismo transmissor, (de modo geral, uma linguagem, traduzida em estilos), que liga uns a outros. O conjunto dos três elementos dá lugar a um tipo de comunicação inter-humana, a literatura, que aparece, sob este ângulo, como sistema simbólico, por meio do qual as veleidades mais profundas do indivíduo se transformam em elementos de conato entre os homens, e de interpretação das diferentes esferas da realidade. (Candido, 1959, v.1, p.17)

Antonio Candido estabelece as condições básicas da existência da literatura social e culturalmente como prática comunicativa, sem no entanto entrar na questão do mercado cultural.

Em convergência com os preceitos de Antonio Candido, sob a óptica do conceituado grupo de estudos de Bordeaux da sociologia da literatura, Robert Escarpit (1970, p.32-3) considera a literatura como "aparelho" e, como tal, ela "compreende uma produção, um mercado e um consumo" (grifo meu).

Escarpit considera que o escritor, consciente ou inconscientemente, tem um projeto que se realiza em forma de livro, e que o leitor tem uma predisposição à leitura desse produto. 
A respeito do produtor, intermediário entre o escritor, sua obra e o leitor potencial, afirma Escarpit (1970, p.32-2):

Le producteur est ce que nous appellerons globalement l'éditeur, c'està-dire l'entrepreneur qui prend la décision, responsable de fabriquer et de mettre en vente le livre. En fait la spécialisation de l'éditeur (qui est auparavant imprimeur ou libraire) date de la fin du XVIII ${ }^{e}$ siècle et de nos jours sa fonction tend à se diviser entre l'éditeur proprement dit qui traite avec l'écrivain et le distributeur oligopolistique qui commercialise le produit.

Le produit littéraire est le résultat d'une série de sélections opérées par divers filtres sociaux, économiques et culturels dans les projets que les écrivains ont menés jusqu'au stade de l'écriture. Le projet avorte si, avant toute mise en œuvre, il n'est pas accepté par un éditeur. L'éditorial et le littéraire débordent d'ailleurs largement l'un et l'autre. Parmi les livres publiés dans le monde, 20 à $25 \%$ des titres, 15 à $20 \%$ des exemplaires seulement sont réputés littéraires, ce qui ne veut pas dire que les autres ne participent pas à la littérature en tant que processus. ${ }^{2}$

Quanto à estatística mencionada, Escarpit assinala que uma mesma obra pode obter a classificação de "Literatura" em um país e de "Ciências Naturais" em outro, ou ainda de "História ou Filosofia" em um terceiro, de acordo com o Index Translatorum, o que revela variações no estabelecimento do critério de "literário" de país para país.

Ainda sobre o papel do editor, continua Escarpit (1970, p.33-4):

Dans tous les pays à économie de marché, l'éditeur applique à tous les livres un critère général de sélection économique. Il achète à l'écrivain celles de ses réalisations dont il pense avoir le placement sur le marché. II peut aller d'un achat pur et simple dans le cas du paiement forfaitaire jusqu'à un salariat déguisé quand l'écrivain possède une image de marque suffisamment sûre pour permettre un investissement régulier. De ce fait l'éditeur exerce une contrainte sur l'écrivain qui se trouve en position fausse puisque précisément son projet est le résultat d'une dialectique dans laquelle il manifeste sa liberté

\footnotetext{
2 "O produtor é o que chamaremos de modo geral de editor, ou seja, o empresário que toma a decisão, responsável por produzir e colocar o livro à venda. A especialização do editor (que era antigamente o impressor ou o livreiro) data, de fato, do final do século XVIII e, atualmente, sua função tende a se dividir entre o editor propriamente dito que negocia com o escritor e 0 distribuidor oligopolista que comercializa o produto.

O produto literário é o resultado de uma série de seleções operadas por diversos filtros sociais, econômicos e culturais nos projetos empreendidos pelo escritor até o estágio da escrita. $\mathrm{O}$ projeto aborta se, antes de ser começado, não for aceito por um editor. O editorial e o literário, aliás, interferem bastante um no outro. Dentre os livros publicados no mundo, 20 a $25 \%$ dos títulos, 15 a $20 \%$ dos exemplares são classificados como literários, o que não significa que os outros não participem da literatura enquanto processo."
} 
individuelle. La contradiction est en général masquée par des artifices de langage qui traduisent la relation économique en relation culturelle.

En outre, en ce qui concerne les livres littéraires, la sélection économique est complétée par une sélection-hiérarchisation émanant de la communauté élitaire des intellectuels, qui délègue ses représentants auprès de l'éditeur sous forme de directeurs littéraires, de conseillers, de lecteurs ou de simples relations personnelles [...] Est réputé littéraire ce qui est perçu comme tel par ces censeurs préalables qui, objectivement opposés à elle ou non, reproduisent les goûts divers, parfois antinomiques, mais toujours fermés en un système, de la classe dirigeante [...]

Ce jury diffus, mais très cohérent, ne se contente pas de sélectionner le produit, il le suscite, l'améliore par des conseils, le domestique dans des collections. Il va même jusqu'à tolérer la recherche génétique dans ces laboratoires semi-officiels ou clandestins qu'on appelle les «avant-gardes », quitte à laisser mourir les produits monstrueux, inviables ou dangereux pour l'ordre de la littérature et à intégrer les autres au cheptel commercialisable. ${ }^{3}$

Tratado como um produto oferecido a um consumidor, o texto literário, original ou traduzido, passa por uma série de intermediações, que consistem em variadas leituras e, por vezes, decorrentes transformações. Compõe-se finalmente um livro que contém o texto propriamente dito, material resultante do trabalho do escritor, e outros textos complementares, como prefácios, posfácios, notas, comentários.

Da concepção do texto original às prateleiras, vários podem ser os destinatários do texto e os tipos de leitura realizados. Enquanto o texto ainda não começou a sofrer o processo de edição, ou mesmo no início desse processo,

\footnotetext{
3 "Em todos os países de economia de mercado, o editor aplica a todos os livros um critério geral de seleção econômica. Ele compra do escritor as realizações que ele pensa poder colocar no mercado. Ele pode desde pura e simplesmente comprar por um preço estabelecido até dar um tipo de salário quando o escritor possui uma imagem de marca suficientemente firme para permitir um investimento regular. Dessa forma o editor exerce uma pressão sobre o escritor que se encontra em posição falseada já que seu projeto é justamente o resultado de uma dialética na qual ele manifesta sua liberdade individual. A contradição é em geral dissimulada por artifícios de linguagem que traduzem a relação econômica em relação cultural.

Por outro lado, no que diz respeito aos livros literários, a seleção econômica é completada por uma seleção-hierarquização que se origina da comunidade elitista dos intelectuais que indica seus representantes junto ao editor sob forma de diretores literários, conselheiros, leitores ou simples relações pessoais [...] É considerado literário o que é percebido como tal por esses censores prévios que, objetivamente opostos a ela ou não, reproduzem os diferentes gostos, por vezes antinômicos, mas sempre fechados em um sistema, da classe dirigente [...]

Esse júri difuso, porém muito coerente, não se contenta em selecionar o produto, ele o suscita, melhora-o com conselhos, domestica-o em coleções. Chega até mesmo a tolerar a pesquisa genética nesses laboratórios semi-oficiais ou clandestinos chamados de 'vanguardas', pronto a
} 
pode-se pensar como destinatário o próprio autor, seus amigos ou destinatários eleitos por ele para apreciarem o texto, os editores potenciais ou pessoas delegadas por um editor para avaliar o texto (pareceristas). Uma vez decidida a publicação da obra, evidencia-se a necessidade de leituras de caráter técnico: seleção, revisão, copidesque etc. Uma vez colocado à venda, o texto vai ao encontro do público leitor. Nessa etapa, podem-se destacar dois grandes tipos de destinatários: por um lado, o leitor potencial, dentre a massa que consome literatura, e, por outro, a crítica especializada.

Esse processo é duplicado quando se trata de literatura traduzida. Robert Escarpit (1970, p.31), na década de 1970, dizia sobre a leitura de literatura traduzida:

Dans la lecture en tant que processus le feedback est assuré par la traduction, l'adaptation, l'illustration, en somme part tout ce qui est œuvre surajoutée. Le médiateur est d'abord le lecteur, puis il dégage de son expérience de lecture une image du projet qu'il assume comme son propre projet et qu'il réalise comme l'écrivain avait réalisé le projet initial. II peut s'insérer dans le processus au stade de la conception ou au stade du " jeu des quatre coins » et, en ce cas, il lui est possible d'éliminer deux des " coins » en acceptant comme un donné objectif le contenu de l'œuvre tel qu'il le perçoit. Cela explique qu'il y ait, comme écrit Georges Mounin, des traductions «à verres transparents » et des traductions «à verres colorés ». Mais quel que soit le type de la traduction, de l'adaptation, de l'illustration, elle constitue bien un feedback, c'est-à-dire une réinjection de l'expérience de lecture, au niveau de l'écriture. ${ }^{4}$

Operacionalmente, neste estudo tratar-se-á dos leitores analisados intermediários no processo de tradução, edição e recepção - como leitores especiais. Os tradutores são leitores privilegiados que trasladam o texto original

deixar perecer os produtos monstruosos, inviáveis ou perigosos à ordem da literatura e a integrar os outros na categoria comercializável."

4 "Na leitura considerada como processo o 'feedback' é garantido pela tradução, a adaptação, a ilustração, em resumo por tudo o que é trabalho posterior. O mediador é, primeiramente, o leitor, depois ele resgata de sua experiência de leitura uma imagem do projeto que ele assume como seu próprio projeto e que ele realiza como o escritor havia realizado seu projeto inicial. Pode se inserir no processo, na fase da concepção, ou na fase do 'jogo de quilhas' e, nesse caso, ele consegue eliminar duas quilhas, ao aceitar como um dado objetivo o conteúdo da obra tal qual ele a percebe.. Isso explica que haja, como escreve Georges Mounin, traduções «como vidros transparentes » e traduções « como vidros coloridos ». Mas qualquer que seja o tipo da tradução, da adequação, da ilustração, ela constitui de fato um 'feedback', isto é, uma reinjeção da experiência de leitura, no nível da escrita." 
para a língua estrangeira. Os editores têm um papel preponderante na escolha de elementos para o lançamento do produto livro. E a crítica especializada receptora, como leitora especializada na área, é normalmente paga para avaliar o produto ao ser lançado no mercado, constituindo assim sua fortuna crítica.

Quanto à obra em si, dentre os cinco tipos de relações transtextuais relacionados por Gérard Genette em Palimpsestes (1982), e desenvolvidos posteriormente em Seuils (1987), lança-se aqui mão do conceito de paratexto: ${ }^{5}$

L'oeuvre littéraire consiste, exhaustivement ou essentiellement, en un texte, c'est-à-dire (définition très minimale) en une suite plus ou moins longue d'énoncés verbaux plus ou moins pourvus de signification. Mais ce texte se présente rarement à l'état nu, sans le renfort et l'accompagnement d'un certain nombre de productions, elles-mêmes verbales ou non, comme un nom d'auteur, un titre, une préface, des illustrations, dont on ne sait pas toujours si l'on doit ou non considérer qu'elles lui appartiennent, mais qui en tout cas l'entourent et le prolongent, précisément pour le présenter, au sens habituel de ce verbe, mais aussi en son sens le plus fort: pour le rendre présent, pour assurer sa présence au monde, sa « réception » et sa consommation, sous la forme, aujourd'hui du moins, d'un livre. Cet accompagnement d'ampleur et d'allure variables, constitue ce que j'ai baptisé ailleurs, conformément au sens parfois ambigu de ce préfixe en français - voyez, disais-je, des adjectifs comme «parafiscal » ou "paramilitaire »-, le paratexte de l'œuvre. Le paratexte est donc pour nous ce par quoi un texte se fait livre e se propose comme tel à ses lecteurs, et plus généralement au public. (Genette, 1987, p.7) ${ }^{6}$

\footnotetext{
${ }^{5} \mathrm{O}$ conceito de paratexto será utilizado neste estudo de forma genérica, sem a especificação dos subconceitos epitexto, peritexto e outros. Eventualmente, esses conceitos serão citados e esclarecidos.

6 "A obra literária consiste, exaustiva ou essencialmente, em um texto, ou seja (definição minimalista) em uma seqüência mais ou menos longa de enunciados providos de significação. Mas esse texto raramente se apresenta desnudo, sem o reforço e o acompanhamento de um certo número de produções, verbais ou não-verbais, como um nome de autor, um título, um prefácio, ilustrações, as quais nem sempre se sabe se devem ou não ser consideradas como pertencentes a ele, mas que, em todo caso o cercam e o prolongam, justamente para apresentá-lo, no sentido habitual desse verbo, mas também em seu sentido mais vigoroso, para torná-lo presente, para garantir sua presença no mundo, sua 'recepção' e seu consumo, sob a forma, ao menos hoje, de um livro. Esse acompanhamento de extensão e configuração variáveis, constitui o que nomeie em outra obra, seguindo o sentido por vezes ambíguo desse prefixo em francês - observe-se, como dizia eu, adjetivos como 'parafiscal' ou 'paramilitar' -, o paratexto da obra. O paratexto é, assim, para nós o elemento pelo qual um texto se faz livro e se propõe como tal a seus leitores, e mais geralmente ao público."
} 


\section{Panorama geral}

Desde quando a França começou a observar o Brasil e a ter interesse por suas produções literárias? O contato se estabeleceu via traduções, porém caberia perguntar quais seriam os critérios de escolha do que deveria ser traduzido e como esse produto da periferia poderia ser consumido pelo centro. Em tempos de globalização e integração de mercados, qual a posição atual do Brasil na política de tradução da ficção brasileira na França?

O interesse da França pelo Brasil existe desde antes da descoberta pelos portugueses. A partir do século XVI, com o início da colonização, a literatura considerada de viagem e os textos de teor etnográfico atestam a curiosidade dos franceses e testificam a construção de uma imagem exótica do Brasil e dos brasileiros ao longo desses cinco séculos. De Jean de Léry a Paulo Coelho, o Brasil tem marcado presença no gosto dos franceses e instigado o seu imaginário.

O interesse da França - e dos países francófonos, também consumidores das editoras francesas - pelo Brasil literário, em razão da própria história da literatura brasileira, é, no entanto, mais recente. O empenho dos franceses em conhecer a literatura brasileira data do século XIX. Algumas raras traduções e publicações de obras literárias brasileiras testemunham essa simpatia pelos autores tropicais, ${ }^{7}$ como Tomás Antonio Gonzaga e o Visconde de Taunay (cf. Abreu, 2004).

Em se tratando de antologias e coletâneas, vale aqui citar algumas publicações, como Le Brésil littéraire, organizado por Ferdinand Josef Wolf, em 1863, que apresenta um panorama da história literária brasileira com trechos de alguns autores nacionais, e La poésie au Brésil, de 1885, com tradução de Émile

\footnotetext{
${ }^{7}$ Fontes: Banco de dados do Nupebraf (IEA-USP); site $<$ http://www.librairie-compagnie.fr $>$. E http://www.ehess.fr/centres/crbc/cbc-thes/litte.html (Centre des recherches sur le Brésil Contemporain)
} 
Alain, que é publicado em coleção "Le Monde poétique", sob a organização de Melo Morais Filho.

José de Alencar, Graça Aranha, Machado de Assis, Graciliano Ramos, Vinícius de Morais e Érico Veríssimo são apenas alguns autores de literatura brasileira que marcam tímida presença na França até as décadas de 1950 e 1960, por meio de traduções e publicações. Jorge Amado é um caso à parte.

Com respeito às coletâneas, nas primeiras décadas do século $X X$, destacase a Anthologie des poètes brésiliens, com organização e traduções de Hippolyte Pujol, apresentando um panorama da poesia brasileira com textos de Alvarenga Peixoto a Amadeo Amaral.

Ainda no início do século XX, das duas publicações organizadas pelo belga Victor Orban, apenas uma antologia foi consagrada à prosa, e mesmo assim juntamente com alguns poetas: a Anthologie française des écrivains brésiliens, cuja primeira edição data de 1911, foi reeditada em 1914 sob o título de Littérature brésilienne, e apresenta junto a textos poéticos trechos de romances e textos críticos, e até mesmo de caráter jurídico ou histórico. Paralelamente, Victor Orban traduz poemas e organiza a coletânea Poésie brésilienne, na qual insere trechos de Iracema, e que terá publicação em 1922 (cf. Pereira, 2005, p.86-97).

Em comunicação intitulada "Poesia brasileira na belle époque francesa", texto que se tornou capítulo da obra Intermediações literárias: Brasil-França, em co-autoria com Maria Luiza G. Atik, Helena B. C. Pereira relaciona e analisa essas duas obras atentando para dois aspectos: a seleção do repertório e o tratamento dado a cada um dos textos ao serem transpostos para a língua francesa. Pereira (2005, p.90) reconhece a validade da tentativa de Orban, mesmo que o processo de seleção de textos tenha pecado por uma visão sem perspectiva panorâmica e o resultado revele "uma concepção equivocada do processo de tradução poética", comprometendo a iniciativa.

Quanto à seleção, revela-se na Poésie brésilienne um critério de afinidade ou gosto pessoal do organizador, sobressaindo "uma valorização da contemporaneidade que se evidencia na quantidade de textos de poetas da virada do século XIX para o XX" (ibidem) Quase um século depois, teriam as leis de 
mercado transformado completamente esse critério de seleção de obras a serem traduzidas?

Ainda segundo análise de Pereira, essas obras se destacam por apresentar a literatura brasileira "não por seus componentes exóticos ou pitorescos, mas porque se constituía em legítima herdeira da cultura latina, imbuída do pensamento francês e encaminhando-se para um futuro promissor" (ibidem, p.96).

Nota-se, pois, ao se apreciar o conjunto de publicações traduzidas, a supremacia do gênero poético sobre a prosa, mas, sobretudo, pode-se observar a pouca valorização de gêneros de prosa curta, mesmo que a França se interesse, vez ou outra, por esse tipo de literatura, como comprova, por exemplo, o sucesso de seus contistas Nodier, Gauthier, Mérimée e Maupassant no século XIX. Em 1939, a Anthologie de quelques conteurs brésiliens vem quebrar o monopólio da poesia, mas não por muito tempo, pois somente em 1958 mais uma antologia de contos aparecerá em meio às antologias de poesia (La poésie brésilienne - 1941; Introduction à la poésie Ibero-américaine - 1947; Anthologie de la poésie brésilienne contemporaine - 1954; Anthologie de la poésie ibero-américaine 1956). Mais uma vez, Les vingts meilleurs nouvelles de l'Amérique latine, trazendo textos de Mário de Andrade e Guimarães Rosa, em 1958, quebra a supremacia da poesia sobre a prosa curta nas antologias e coletâneas.

É somente a partir das décadas de 1960-1970 que os gêneros tendem a se equilibrar mais harmoniosamente, no que se refere ao interesse dos franceses pela literatura brasileira.

Segundo alguns levantamentos recentes, de aproximadamente 1.500 obras brasileiras recenseadas em língua francesa (Abreu, 2004), cerca de novecentos títulos correspondem a traduções de obra brasileira traduzida e publicada na França. De onde se conclui que os demais títulos, em torno de seiscentos, foram escritos diretamente em francês e/ou publicados em outros países. São 406 os autores repertoriados, e quase a metade (139 homens e 52 mulheres) é composta por poetas, romancistas, contistas, biógrafos e dramaturgos. A outra parte dos 406 autores consagrou-se à realização de obras de teor social, político, religioso, econômico etc. Esses números são reveladores do interesse da França pelo 
Brasil, no que se refere à antropologia ou aos direitos humanos, por exemplo. A prosa narrativa brasileira passou a constituir o gênero mais traduzido de literatura brasileira em francês. Vale salientar que a tradução e a publicação dessa prosa não respeita, no entanto, uma regularidade crescente. Alguns períodos, conforme se pode observar no estudo de Marie-Hélène Catherine Torres (2004), foram menos propícios à tradução de obras brasileiras, sobretudo nas décadas de 1930 e 1960, em decorrência, entre outros motivos, da conjuntura sociopolítica. Justificam-se, pois, estudos que examinem minuciosamente a recepção de literatura brasileira traduzida na França.

Vale aqui salientar alguns nomes da literatura brasileira traduzidos na França, mesclando os gêneros, a partir da década de 1960.

A partir dessa década, enquanto alguns autores como Machado de Assis e, sempre, Jorge Amado são reeditados com certa freqüência, autores de literatura brasileira mais antigos, como Aluísio Azevedo e outros mais contemporâneos, começam, pouco a pouco, a ser traduzidos e publicados. Muitos não passarão dos anos 1960, como Rubem Braga. Outros autores conhecerão tímida tradução e publicação nesses anos e despontarão nos anos 1970, 1980 e 1990. Dentre esses citam-se Autran Dourado, Lygia Fagundes Telles, Guimarães Rosa

Outros autores só terão tradução e publicação de certas obras na íntegra a partir das décadas de 1970 e 1980, como Osman Lins, Antonio Callado, Carlos Drummond de Andrade, Zélia Gattai, Josué Montello, Raduan Nassar, Nélida Piñon, Rachel de Queiroz, João Ubaldo Ribeiro, José Mauro de Vasconcelos e, mais recentemente, Moacyr Scliar, Márcio Souza, Antonio Torres e Clarice Lispector. Essa última obtém, a partir da década de 1990, um grande sucesso, e sua obra é recepcionada como literatura feminina. ${ }^{8}$

\footnotetext{
${ }^{8}$ A tese de doutorado de Lúcia Peixoto Cherem "Um olhar estrangeiro sobre a obra de Clarice Lispector: leitura e recepção da autora na França e no Canadá (Quebec)", defendida em 2003 na Universidade de São Paulo versa justamente sobre esse tema.
} 
Na década de 1990, o leitor francês pode melhor conhecer a obra de Caio Fernando Abreu, Bernardo Carvalho, Roberto Drummond, Milton Hatoum, Hilda Hilst, Dalton Trevisan e, finalmente, Patrícia Melo e Paulo Coelho.

O novo milênio apresenta a publicação na França de Ferreira Gullar, Paulo Lins e Luis Fernando Veríssimo.

Embora o Brasil sempre tenha sido alvo da curiosidade dos franceses, a literatura brasileira tem tido maior destaque nesses últimos trinta anos na França. A mídia especializada ressaltou nesse período algumas ocasiões em que o Brasil se destacou no cenário francês.

Em 1985, uma publicação especial de Libération convidou, como mencionado no início deste capítulo, 400 escritores do mundo inteiro a responderem à pergunta "Pourquoi écrivez-vous?". Aproximadamente duas páginas são consagradas ao Brasil. Antonio Callado, Autran Dourado, Carlos Drummond de Andrade, Jorge Amado, Rubem Fonseca, Fernando Gabeira, Raduan Nassar, Darcy Ribeiro, João Ubaldo Ribeiro, Napoleão Sabóia, Moacyr Scliar, Márcio Souza, e Antonio Torres são os escritores brasileiros que deram seu depoimento. Cada testemunho é precedido de uma foto $(3 \mathrm{~cm} \times 4 \mathrm{~cm})$ do autor e de uma pequena biografia. Evidentemente é dado maior espaço a Jorge Amado, cuja foto $(15 \mathrm{~cm} \times 21,5 \mathrm{~cm})$ atrai de imediato a atenção do leitor. Alguns autores já haviam sido publicados na França, como Autran Dourado, nos anos 1960 e Callado, Drummond, Darcy Ribeiro João Ubaldo Ribeiro, na década seguinte. No final dos anos 1970 e início de 1980, Rubem Fonseca, Márcio Souza e Antonio Torres acabavam de ser publicados pela primeira vez. Quanto a Raduan Nassar e Moacyr Scliar, 1985 é justamente o ano de sua primeira publicação. Pode-se avaliar que Libération buscou mesclar autores mais e menos conhecidos do público francês.

Em 1987, o Brasil inaugura, a convite do Ministério da Cultura, o projeto "Les belles étrangères": 9

\footnotetext{
${ }^{9}$ Cf. <http://www.diplomatie.gouv.fr/label_France/FRANCE/LETTRES/etrangeres/page.html> $<$ <ttp://www.centrenationaldulivre.fr/Les-Belles-Etrangeres>.
} 
"Les belles étrangères..." Sous ce titre - ô combien séduisant! - le Centre National de Lettres et la Direction du Livre lancent une opération de longue haleine afin de permettre au public français de se familiariser avec les littératures venues d'ailleurs. "Les » belles étrangères » que nous voulons vous faire découvrir, ce sont ces littératures qu'il est inadmissible de dire " mineures », alors que, tout simplement, tous ceux qui les aiment n'ont pas encore réussi à nous les faire connaître », a expliqué M. Jean Gattegno. ${ }^{10}$ (Zand, 1987, p.14)

Previa-se naquele mesmo ano a participação da Alemanha, da China, da Dinamarca, da Espanha e da Rússia. Por meio desse projeto, a França acreditava abrir-se ao "outro", embora seja bastante curioso e significativo que o organizador, em seu depoimento, inclua algumas dessas literaturas no que chama de literaturas consideradas "menores".

O evento, inicialmente no mês de março, e em 1987 na ocasião do Salão do Livro de Paris, contou com a presença de mais de quinze escritores brasileiros, entre eles Jorge Amado, Zélia Gattai, Antonio Callado, José Candido de Carvalho, Raduan Nassar, Rubem Fonseca, Lygia Fagundes Telles, Antonio Olynto e João Cabral de Melo Neto.

Com o Projeto "Les belles étrangères", vinte anos após sua primeira edição, a França busca abrir-se ao "outro", estabelecendo uma contraface literária e cultural num contexto mais amplo, que envolve relações diplomáticas, acordos comerciais etc. O sucesso junto ao público é flagrante e "Les belles étrangères" é sempre uma ocasião muito festejada no mercado editorial e no comércio especializado.

Uma década depois, em 1998, o Brasil é convidado de honra do Salão do Livro de Paris. Trinta e cinco autores dentre os quais Antonio Torres, Autran Dourado, Bernardo Carvalho, Carlos Heiitor Cony, Chico Buarque, Dias Gomes, Fernando Gabeira, João Ubaldo Ribeiro, Jorge Amado, Luis Fernando Veríssimo, Lygia Fagundes TellesMárcio Souza, Milton Hatoum, Moacyr Scliar, Nélida Piñon, Plínio Marcos, Raduan Nassar e Zuenir Ventura, entre outros, integram a comitiva.

10 “'Les belles étrangères...' Com esse título - tão sedutor! - o Centre National de Lettres e a Direction du Livre lançam uma operação de grande fôlego a fim de permitir ao público francês que se familiarizasse com as literaturas vindas de outros lugares. "Les » belles étrangères » que nós queremos fazer os franceses descobrirem são essas literaturas que é inadmissível chamar de 
Dessa vez, Rubem Fonseca não estava entre os escritores representantes do Brasil em Paris, mas Patrícia Melo, aos trinta e quatro anos, considerada sua discípula, já participava do grupo, apenas dois anos após o lançamento de $O$ matador em língua francesa.

Um artigo publicado no Le Monde des Livres na ocasião, assinado pela jornalista Estelle Nouel em colaboração com o jornalista e escritor Jean Christophe Rampal, intitulado "Polar sous les tropiques" - Romance policial sob os trópicos merece especial atenção (Nouel, 1998, p.3).

O artigo traz o seguinte lead, que serve de resumo do conteúdo do artigo: "Constitué en genre à part entière à la fin de la dictature, le roman policier est le témoin par son essence même des désordres sociaux". ${ }^{11}$ Após uma introdução que explica rapidamente os então quinze anos de ditadura e a anistia concedida pelo general Figueiredo em 1979 em um contexto de reconciliação política forçada, o artigo apresenta o romance policial como uma tendência latinoamericana de valorização do roman "dur". O depoimento do escritor argentino Mempo Giardinelli, retirado de uma obra clássica consagrada ao romance policial na América Latina, Anthologie de la nouvelle noire et policière latino-américaine, (Fonseca, 1995) reforça as premissas do artigo:

au sortir de la dictature « on ne pouvait faire de la littérature sans passer par le policier. Je veux dire par là qu'il y avait besoin de parler de certaines choses, d'une certaine façon : la réalité sociale, les échecs politiques, les désillusions, tout cela dans un style noir, violent, direct ». (Nouel, 1998, p.3)

A fim de introduzir comentários sobre a obra O matador de Patrícia Melo, os autores afirmam, no artigo, que na sociedade brasileira democracia rima com neoliberalismo e que a miséria e as desigualdades sociais alimentam a violência urbana incapaz de combater uma polícia corrupta (ibidem). Segue-se um resumo de $O$ matador que culmina com o comentário sobre Rubem Fonseca:

« menores », simplesmente porque, todos os que as apreciam ainda não conseguiram torná-las conhecidas», explicou o Sr. Jean Gattegno."

11 "Constituindo-se assumidamente como gênero no final da ditadura, o romance policial é a testemunha por sua própria essência das desordens sociais." 
Mais Patricia Melo, ancienne réalisatrice à TV Globo et scénariste, évoque plus volontiers ses références cinématographiques et notamment, Lacombe Lucien, le film de Louis Malle. Lacombe Lucien devenait collaborateur; Maïquel, le héros de O Matador, bascule dans le crime. «A chacun sa part d'ombre », nous dit Patricia Melo, comme un réquisitoire contre ceux qui accusent de compromission avec le régime militaire son père spirituel, Rubem Fonseca. (ibidem) ${ }^{13}$

Dessa maneira, Rubem Fonseca e sua obra passam a ser o centro das atenções do artigo. São inicialmente fornecidos dados sobre sua biografia: data e local de nascimento, percurso profissional de advogado a crítico cinematográfico, e o detalhe de ele ter sido diretor do Instituto de Pesquisa e Estudos Sociais (IPES) antes do golpe de 1964. Apesar de relatarem que o IPES teve o apoio dos generais golpistas, os articulistas também reforçam o fato de os mesmos generais terem censurado parte da obra de Rubem Fonseca, posteriormente. Uma vez encerrada a menção à eventual participação política do escritor nos acontecimentos dos anos 1960, passa-se à apreciação de sua obra propriamente dita. Nessa parte, o artigo proporciona ao leitor um panorama incompleto da produção fonsequiana traduzida na França. Apesar de reconhecerem que Fonseca possui um estilo flamboyant pelo qual retrata as ambigüidades de sua época e personalidade, por meio de personagens multifacetados, apenas as traduções dos livros Agosto e Vastas emoções e pensamentos imperfeitos serão citadas. Um derradeiro comentário nessa parte do artigo aponta as intrigas cariocas presentes na obra de Fonseca como contraponto ao regionalismo tanto de Guimarães Rosa como de Jorge Amado, esse último considerado símbolo de exotismo brasileiro:

On y découvre un Brésil libéré de son carcan exotique. Derrière une apparente joie de vivre, le peuple rumine sa haine contre le pouvoir et l'armée. Les

\footnotetext{
12 "no final da ditadura, « não se podia fazer literatura sem passar pelo policial. Quero dizer com isso que havia a necessidade de se falar de certas coisas, de uma certa forma: a realidade social, os fracassos políticos, as desilusões, tudo isso num estilo negro, violento, direto »."

13 "Mas Patrícia Melo, ex-diretora na TV Globo e autora de cenarista, evoca facilmente suas referências cinematográficas e sobretudo, Lacombe Lucien, o filme de Louis Malle. Lacombe Lucien se tornara colaborador; Maiquel, o herói de $O$ matador, cai no crime. 'Cada um com sua sombra', nos diz Patrícia Melo, como que incriminando os que acusam de compromisso com o regime militar seu pai espiritual, Rubem Fonseca."
} 
mafiosi infiltrent le carnaval, et les Noir subissent quotidiennement le racisme. ${\text { (ibidem })^{14}}^{14}$

A seqüência do artigo contrapõe Rubem Fonseca a Chico Buarque e Bernardo Carvalho, autores que viveram no exílio. Uma breve menção é feita a Jô Soares, como um autor que está mais para a telenovela do que para a literatura.

Para encerrar o artigo, tece-se um comentário muito relevante a respeito da inexistência de uma coleção dedicada à "série noire":

Malgré la popularité croissante du polar, et contrairement au Mexique ou à l'Argentine, il n'existe au Brésil aucune collection de série noire. Une frilosité que ne partagent pas les éditeurs de bandes dessinées, qui ont créé une collection entièrement consacrée au policier. (ibidem) ${ }^{15}$

Em 2005, o Brasil foi mais uma vez o país homenageado no Salão do Livro de Paris, por ter sido instituído o "Ano do Brasil na França". Vale salientar que o referido Salão do Livro, que tem como foco o leitor, muitas vezes é influenciado pela Feira do Livro de Frankfurt, maior evento editorial do mundo. Nessa feira, cuja prioridade são as editoras, a participação brasileira vem aumentando nos últimos anos. Em 2003, o Brasil ficou em 29 lugar em número de expositores, e no ano seguinte, subiu para a 13a posição (cf. FolhaOnline, 15.10.2005, 09h02).

\section{Em destaque: a fortuna crítica de Rubem Fonseca}

Pode-se considerar que o leitor francês teve acesso à obra de Rubem Fonseca apenas nos anos 1980, pois a primeira tradução de que se tem notícia foi realizada e publicada em 1979.

\footnotetext{
14 "Descobre-se aí um Brasil liberado de sua canga exótica. Por trás de uma aparente alegria de viver, o povo rumina seu ódio contra o poder e o exército. Os mafiosos infiltram-se no carnaval e os negros agüentam diariamente o racismo."

15 "Apesar da popularidade crescente do romance policial e, contrariamente ao México ou à Argentina, não existe no Brasil nenhuma coleção de série noire. Uma timidez que os editores de histórias em quadrinhos não compartilham, pois criaram uma coleção inteiramente consagrada ao gênero policial."
} 
Com base no conjunto do material pesquisado, pode-se deduzir que Marguerite Wünscher foi a primeira tradutora de Rubem Fonseca para a língua francesa, ao traduzir o único livro de contos publicado integralmente, Bonne et heureuse année, e o primeiro romance de Rubem Fonseca, Le cas Morel. Ambos foram publicados em 1979 numa mesma edição. Segundo a própria tradutora, tratou-se de uma estratégia editorial: Lise Lebel, diretora literária da Flammarion desejava publicar, nos anos 1970, autores contemporâneos brasileiros.

Professora de literatura francesa de 1974 a 1977 na Aliança Francesa de São Paulo, então sob a direção de Jacques Thiériot, Marguerite Wünscher, ao retornar à França, quis mostrar o verdadeiro Brasil aos franceses:

En rentrant en France, je souhaitais faire connaître ici le "vrai" Brésil, pas seulement celui des plages et du carnaval, mais celui de tous les jours, celui des brésiliens. Pour sortir des clichés, rien ne vaut la littérature. Nous connaissions surtout à l'époque les romans de George Amado (sic). Une amie brésilienne, Estela DOS SANTOS ABREU, qui connaissait très bien la France et travaillait dans l'édition, m'a mise en contact avec Lise LEBEL, directrice littéraire chez Flammarion, décédée aujourd'hui. Cette personne voulait prendre le risque de publier des livres brésiliens actuels. $(4.9 .2005)^{16}$

Seu testemunho esclarece sobre o processo de seleção de autores contemporâneos brasileiros e a escolha dos autores Rubem Fonseca e, posteriormente, Ivan Ângelo, revelando-nos a elaboração de um estudo literário de mercado.

Sur proposition d'Estela, j'ai donc commencé à lire beaucoup d'ouvrages en rédigeant des fiches de lecture. Nous avons sélectionné Rubem Fonseca qui nous offrait un miroir de certains côtés de la société urbaine, sans trop de traces d'exotisme. Je pensais que le lecteur français n'aurait pas de peine à s'y retrouver. Le cas Morel était facile à lire à cause de sa structure en roman policier qui évitait le didactisme quand il évoquait la désintégration d'une société proche de la nôtre.

Les nouvelles qui composaient Bonne et heureuse année étaient aussi très abordables et leur ton satirique et noir ne pouvait que séduire les lecteurs.

\footnotetext{
16 "Voltando à França, eu quis mostrar aqui o 'verdadeiro' Brasil, não somente aquele das praias e do carnaval, mas o de todos os dias, o dos brasileiros. Para sair dos clichês, nada como a literatura. Conhecíamos na época, sobretudo os romances de Jorge Amado. Uma amiga brasileira, ESTELA DOS SANTOS ABREU, que conhecia muito bem a França e trabalhava no ramo da edição, me colocou em contato com Lise LEBEL, atualmente falecida, diretora literária na Flammarion. Essa pessoa queria correr o risco de publicar livros brasileiros atuais."
} 
Pour vous montrer la cohérence de nos choix, j'ai également traduit la même année La Festa d'Ivan Angelo, qui recoupait nos premiers choix par son regard journalistique sur le Brésil des années 70. (4.9.2005) ${ }^{17}$

A festa (La fête), de Ivan Ângelo, foi igualmente publicado em 1979, pela Flammarion.

O depoimento de Marguerite Wünscher revela-nos ainda o provável motivo da interrupção do projeto de Lise Lebel:

Je ne crois pas que ces livres aient eu beaucoup de succès, mais ils ont eu le mérite d'ouvrir une brèche, et les éditeurs se sont très vite ensuite emparé du créneau brésilien. Aujourd'hui, contrairement à l'époque, le Brésil est bien présent dans les catalogues. $(4.9 .2005)^{18}$

Questionada sobre a não-publicação de outros livros de conto de Rubem Fonseca, Wünscher considerou:

L'une de vos questions portent sur le seul livre de nouvelles traduit. La raison en est simple. Jusqu'à très récemment, les français ne s'intéressaient pas aux nouvelles. Ils ne lisaient que celles des grands auteurs anglo-saxons. Aujourd'hui la situation a changé. Beaucoup de jeunes auteurs français en publient. L'émulation vient aussi de concours de nouvelles ouverts à n'importe qui. De ce fait, les lecteurs sont plus nombreux et on commence à ne plus les considérer comme un genre mineur.

C'est d'ailleurs pour cette raison que l'éditeur a choisi de publier ENSEMBLE le roman avec les nouvelles. Les nouvelles seules ne se seraient pas vendues. $(4.9 .2005)^{19}$

17 "Por sugestão de Estela, comecei, então, a ler muitas obras, redigindo fichas de leitura. Selecionamos Rubem Fonseca que nos oferecia um espelho de certas facetas da sociedade urbana, sem excesso de traços de exotismo. Eu acreditava que o leitor francês não teria dificuldades em se identificar com ele. O caso Morel era fácil de ler por ter uma estrutura de romance policial que evitava o didatismo quando ele evocava a desintegração de uma sociedade próxima da nossa.

Os contos que compunham Feliz ano novo eram também muito acessíveis e seu tom satírico e 'noir' só podia seduzir os leitores.

Para mostrar a coerência de nossas escolhas, traduzi também, no mesmo ano, A Festa, de Ivan Ângelo, que confirmava nossa primeira escolha por seu olhar jornalístico sobre o Brasil dos anos 70."

18 "Não creio que estes livros tenham tido muito sucesso, mas tiveram o mérito de abrir um espaço e os editores rapidamente se apossaram do segmento brasileiro. Hoje em dia, ao contrário daquela época, o Brasil está bastante presente nos catálogos."

19 "Uma de suas questões trata do único livro de contos traduzido. A razão disso é simples. Até muito recentemente os franceses não se interessavam pelos contos. Só liam os dos grandes 
Outro questionamento dizia respeito ao eventual contato entre o autor e a tradutora, ao que respondeu: "J'ai rencontré Rubem Fonseca une fois au Brésil rapidement" (4.9.2005). Embora não tenha estabelecido contato pessoal mais próximo com Rubem Fonseca, Wünscher contou com a intermediação constante de Estela dos Santos Abreu, que contribuiu para o esclarecimento de inúmeras dúvidas.

Cabe a Marguerite Wünscher o mérito de ter enfrentado o desafio de traduzir Rubem Fonseca para o francês, apostando na sua modernidade, evitando a folclorização ou apelo fácil ao exotismo. Outra façanha foi a publicação dos contos de Feliz ano novo junto com o romance.

A publicação de Le cas Morel suivi de Bonne et heureuse année em 1979 coincide com os quinze anos de ditadura militar no Brasil. Pode-se notar, pelo conteúdo dos artigos, que essa informação foi bem veiculada para a imprensa, provavelmente pela própria editora, que enviou material de divulgação, e, como se poderá constatar, foi devidamente explorada pelos articulistas. Dois artigos, relativamente longos, são consagrados ao lançamento do escritor brasileiro. O primeiro, em abril de 1979, no Magazine Littéraire (rubrica "Romans"), e o segundo, em junho, em La Quinzaine Littéraire (rubrica "Romans", "récits"...). As duas publicações atingem um público leitor que vai do simples interessado em literatura ao especialista. Ambos os artigos trataram tanto de Le cas Morel suivi de Bonne et heureuse année, de Rubem Fonseca, quanto de La fête inachevée, de Ivan Angelo, publicados pela Flammarion, com tradução de Marguerite Wünscher. Esses dois artigos, longos e detalhistas, merecem aqui análise e considerações pormenorizadas.

Gérard Cortanze, no primeiro artigo, apresenta a situação política e econômica brasileira nos três primeiros parágrafos, para então introduzir os romances dos dois escritores. O título, "Le brésil sans folklore" (sic), promete uma

autores anglo-saxões. Hoje a situação mudou. Muitos jovens autores franceses publicam contos. 0 estímulo vem também dos concursos abertos a qualquer pessoa. Por isso, os leitores são mais numerosos e começa-se a não mais considerá-lo um gênero menor. 
nova visada na literatura brasileira por meio de uma análise histórica, sem o exotismo que ocorre habitualmente. Quatro linhas de lead antecedem o artigo propriamente dito, resumindo-o:

Pays étonnat peut-être bientôt l'un des troisième ou quatrième du monde. Empire en 1888, il passe par le positivisme d'Auguste Comte, républicain, pour subir aujourd'hui dans le régime des maréchaux. Entre temps, il y eut le caoutchouc, puis la faillite des plantations. Aujourd'hui l'inflation délirante. C'est de ce Brésil là dont nous parlent avec férocité et amertume Ivan Angelo et Rubem Fonseca. (Cortanze, 1979, p.26) ${ }^{20}$

Nessa pequena apresentação, bastante apelativa ao exortar a situação econômica do Brasil, vislumbram-se, sobretudo, os aspectos históricos. Atente-se para a menção ao republicano positivista Auguste Comte que, de certa forma, relaciona o Brasil à França: mais uma maneira de interpelar a atenção do leitor. Esse recurso será amplamente utilizado, como se verá a seguir.

O primeiro parágrafo evoca o imperador Dom Pedro II, relacionando-o a amizades francesas: "Le 13 mai 1888, l'Empereur Dom Pedro II, ami de Renan, de Maspero, de Pasteur, de Victor Hugo, abolissait l'esclavage" (ibidem). ${ }^{21}$

Cortanze prossegue a narração histórica evidenciando os vínculos com a história da França: cita o suíço Benjamin Constant e suas idéias revolucionárias, o positivismo de Auguste Comte, e até afrancesa nomes próprios como Alberto Torres, que se tornou Albert Torres. ${ }^{22}$ Ele traça, assim, um panorama bastante sucinto da história do Brasil até 1964. Esse recurso sensibiliza o leitor, conhecedor ou não do Brasil e de sua história, aproximando-o da realidade brasileira. A seqüência do artigo sugere que o leitor francês, se não conhece a história mais

Aliás, é por esta razão que o editor escolheu publicar JUNTOS o romance e os contos. Os contos sozinhos não venderiam."

20 "País surpreendente, logo será o terceiro ou quarto do mundo. Império em 1888, passa pelo positivismo de Auguste Comte, republicano, para sofrer hoje no regime dos marechais. Nesse ínterim, houve a borracha, depois a falência da lavoura. Hoje, a inflação delirante. É desse Brasil que nos falam com ferocidade e amargura Ivan Angelo e Rubem Fonseca."

21 "Em 13 de maio de 1888, o Imperador Dom Pedro II, amigo de Renan, de Maspero, de Pasteur, de Victor Hugo, abolia a escravidão."

${ }_{22}$ Questionou-se aqui se seria um afrancesamento eventual desse autor, um afrancesamento corrente na França, ou simplesmente um erro tipográfico. Segundo pesquisa, não há afrancesamento corrente do nome Alberto Torres. Subsiste a primeira ou a terceira hipótese. 
antiga do Brasil, está (ou não pode mais deixar de estar), porém, familiarizado com sua história recente:

On connaît la suite: Actes Institutionnels supprimant les partis politiques traditionnels, augmentation des pouvoirs de'exception du Président, réforme judiciaire déniant aux prisionniers politiques le droit d'habeas corpus, suspension sie die du Parlement créations d'organismes militaires et policiers de lutte contre la «subversion» (CODI, DOI, DOPS, PIC, GOE, DPF,...) pratiquant très systèmatiquement les tortures les plus odieuses (« churrasquinho », « geladeira », « palmatoria », « pau de arara »,...), - la rue étant laissé aux groupes fascistes. (ibidem) ${ }^{23}$

Salienta-se que o nome dado às diferentes modalidades de tortura está em português no texto francês.

Os exilados políticos são o assunto inicial do segundo parágrafo. A França foi um dos países que mais acolheram refugiados políticos na década de 1970. Portanto, se o leitor desconhece a maior parte das informações históricas do início do artigo, a evolução da política brasileira, as práticas de tortura, possivelmente, com a leitura desse trecho passa a ter elementos para se envolver mais no texto.

Um terceiro momento é consagrado à economia, indicando o PIB de 10\% entre 1964 e 1974, a crise e a inflação de 50\% em 1976.

Uma vez preparado, então, o leitor é convidado a descobrir dois escritores brasileiros inseridos no contexto apresentado:

C'est de ce Brésil-là dont nous parlent avec férocité et amertume La fête inachevée et Le cas Morel, mais comme dans une vision inversée et en excluant tout misérabilisme. En dénonçant la décrépitude d'une oligarchie brésilienne composée "d'arrivistes endimanchés [...], élegants, propes et en bonne santé, souriants, aimables, cérimonieux, satisfaits », lentement corrompus par l'ennui, l'angoisse, la peur, Rubem Fonseca et Ivan Angelo dressent un implacable réquisitoire, défini ainsi par ce dernier : "Ce livre n'est pas seulement un livre d'histoires [...], mais il est surtout une discussion, un

\footnotetext{
23 "Sabe-se o que ocorreu em seguida: Atos Institucionais suprimindo os partidos políticos tradicionais, aumento do poder especial do Presidente, reforma judiciária negando aos presos políticos o direito ao habeas corpus, suspensão sine die do Parlamento, criação de organismos militares e policiais de luta contra a « subversão » (CODI, DOI, DOPS, PIC, GOE, DPF,...) que praticaram muito sistematicamente as torturas mais execráveis (« churrasquinho », " geladeira », « palmatória », « pau de arara »,..), - enquanto a rua era deixada aos grupos fascistas."
} 
étonnement, un témoignage, une investigation, une déposition, une enquête sur l'homme brésilien ». (ibidem) ${ }^{24}$

A atualidade e o teor de testemunho histórico, de denúncia de ambos os textos, serão reforçados ao longo do artigo, como assinala Ivan Angelo: "J'ai senti la nécessité de témoigner, de proposer une vision dramatique du Brésil d'aujourd'hui, à travers un traitement littéraire soigné" (ibidem). ${ }^{25}$

O artigo conta com o depoimento de Ivan Angelo, mas não com o de Rubem Fonseca. Talvez, por isso, seja dado maior espaço ao primeiro, e somente após o testemunho de Ivan Angelo surgem algumas linhas introdutórias ao conteúdo do romance de Rubem Fonseca:

Dans Le cas Morel, Rubem Fonseca, utilisant la structure du roman policier, tente de mener une enquête pour savoir si Morais-Morel qui voulait faire une expérience en vivant avec plusieurs femmes (Ismène, Carmen et Joana), a vraiment tué l'une d'entre elles, trois matériaux étant à la disposition du romancier-policier: ce que dit le narrateur, ce que dit le roman de MoraisMorel, ce que retracent les pages du journal retrouvé de Joana-Heloïsa. (ibidem, p.26-7) ${ }^{26}$

O artigo destaca primeiramente os dois romances para, em seguida, consagrar espaço à coletânea de contos de Rubem Fonseca.

A partir da apresentação do romance de Fonseca, o autor do artigo mescla as narrativas, citando os traços, ora comuns ora díspares, entre elas num aparente exercício literário. Ao evocar o subtítulo do romance de Ivan Ângelo, Roman-contes, e a evidente referência a Graciliano Ramos,".tanto na forma

\footnotetext{
24 "É deste Brasil que nos falam com ferocidade e amargura A festa e O caso Morel, porém, com uma visão invertida, excluindo qualquer miserabilismo. Denunciando a decrepitude de uma oligarquia brasileira composta por «janotas arrivistas [...] elegantes, limpinhos, com boa saúde, sorridentes, amáveis, cerimoniosos, satisfeitos», lentamente corroídos pelo tédio, a angústia, o medo, Rubem Fonseca e Ivan Angelo constróem um implacável tribunal, definido por este último da seguinte maneira: «Este livro não é somente um livro de histórias [...] é sobretudo uma discussão, uma surpresa, um testemunho, uma investigação, um depoimento, uma sondagem sobre o homem brasileiro»."

25 "Senti a necessidade de dar meu testemunho, de propor uma visão dramática do Brasil de hoje por meio de um cuidadoso tratamento literário."

26 "Em O caso Morel, Rubem Fonseca, utilizando a estrutura do romance policial, tenta conduzir uma investigação para saber se Morais/Morel, que queria fazer uma experiência vivendo com diversas mulheres (Ismenia, Carmen e Joana) realmente matou uma delas, sendo que três tipos de
} 
quanto na apropriação cruel da angústia que aumenta e anima o subtítulo no que ele tem de caleidocóspico" (ibidem), reaproxima novamente os romances em sua estrutura narrativa, fragmentária, reflexo de dramas psicológicos, até finalmente categorizá-los como textos políticos, nos quais há a crítica dos costumes de uma "geração sem saída" que vê surgir por volta dos anos 1970 "a falência do racionalismo comtiano e a tomada militar de 1891 e em seguida de 1964" (ibidem), retomando assim o fio das informações contidas nos parágrafos introdutórios.

A crítica avança entrecruzando obras e autores, fragmentos dos textos, metalinguagem dos próprios textos em sua estrutura fragmentária, que parece finalmente concluir parte do artigo para introduzir comentários referentes aos contos de Fonseca:

Livres du malaise, de la tristesse, d'une certaine nostalgie [...] le lien entre ces différentes séquences est donné par le montage, par une macaronique imbrication toute cinématographique d'un univers romanesque et de ses éléments où chaque récit - dispersé par l'éclatement des points de vue dans ce qu'ils perdent et s'opèrent - apparaît comme une scène close par un fondu au noir, fil conducteur court-circuiteur réunissant, lors d'une ultime séquence nidifiante et dissipatrice, les clefs d'idéogrammes passionnels. Ainsi, cette bonne et heureuse année, recueil de quinze nouvelles, pourrait très bien se clore sur un après la fête, réunissant les éléments disparates d'un texte complet disséminé par le fragment, l'inachèvement, l'échec... (ibidem) ${ }^{27}$

E é do aspecto fragmentário dos textos que surge o ponto mais instigante da análise de Cortanze: mais do que a angústia de uma "geração sem saída", esses escritores tratam de "situações". Sua ficção denuncia as máscaras sociais, a censura e a hipocrisia. Se, por um lado, os romances apresentam em sua estrutura "uma imbricação macarrônica cinematográfica de um universo romanesco e de seus elementos“ (ibidem), os contos aparecem como estilhaços do real compilados pelo contista. Apoiando-se em dois escritores, o uruguaio Roa

material estão à disposição do romancista-policial: o que diz o narrador, o que diz o romance de Morais-Morel,o que está presente nas páginas do diário de Joana-Heloísa."

27 "Livros do mal estar, da tristeza, de uma certa nostalgia [...] o elo entre essas diferentes seqüências é criado pela montagem, por uma macarrônica sobreposição, bem cinematográfica, de um universo romanesco e de seus elementos, onde cada narrativa - dispersada pela explosão das pontos de vista no que eles perdem e se produzem - aparece como uma cena fechada por um fade out, fio condutor que provoca um curto-circuito reunindo, em uma última seqüência que aninha e dissipa, as chaves de ideogramas passionais. Assim, este feliz ano novo, compilação de quinze contos, poderia muito bem terminar em um fim de festa que reúne elementos díspares de um texto completo, disseminado pelo fragmento, a não conclusão, o fracasso..." 
Bastos e o francês Maurice Roche, Cortanze legitima, ao exortar os contos de Bonne et heureuse année, a originalidade fragmentária e dilacerante dos romances.

$\mathrm{O}$ articulista encerra o artigo referindo-se nostalgicamente a uma certa ingenuidade presente em Grande sertão: veredas e Macunaíma. Ingenuidade essa que teria desaparecido nesses "romances vigorosos e duros que surgem como uma insuportável e necessária descida aos infernos da podridão" (ibidem). Possivelmente em busca de um "fecho de ouro", o autor encerra seu artigo com uma grandiosidade digna das pseudo-epopéias nele descrito, ou seja, com as mesmas marcas de exagero que permearam sua prosa crítica: "Cruel, surpreendente, amarga, tensa, naturalista, esta floresta amazônica sombria avança, como a de Macbeth, no coração de uma cidade de madeira" (ibidem).

"Le Brésil des années 70", escrito pela renomada tradutora e ensaísta Alice Raillard para La Quinzaine Littéraire, traz a indicação das publicações e de imediato introduz a informação sobre o aniversário do golpe militar: "No último dia 31 de março, o regime militar brasileiro estava há quinze anos no poder. Alguns dias antes, o general Figueiredo, quinto chefe do governo desde o golpe de Estado, tomava posse, iniciando uma era de expectativa para não dizer de esperança" (Raillard, 1979).

Raillard considera que seu leitor está a par da realidade política brasileira, pois o trata como um conhecedor. Além de se dirigir a um público que não é completamente leigo, a articulista utiliza um recurso legítimo para valorizar seu repertório cultural. Na seqüência, faz referências ao "milagre" brasileiro, à desigualdade social e à crise econômica, tudo no parágrafo introdutório. A apresentação do romance vem em seguida:

Deux ouvrages apportent, chacun à leur manière, un éclairage sur ce Brésil des années 70. Ou, du moins, sur certains aspects d'un Brésil parmi tant de Brésils, dont on parle ou ne parle pas. 
Le leur a des tons doucement pourrissants à la chaleur des tropiques, dans l'amertume des idéaux déçus et le ronron de la télé. Ventres trop pleins ou ventres vides... (ibidem) ${ }^{28}$

Como no artigo anterior, evidencia-se primeiramente a obra de Ivan Angelo, como "flashes sucessivos", uma "montagem de textos", que sobrepõe habilmente "a uma sátira de costumes de estilo burguês, uma narrativa socialmente engajada" (ibidem). É um trecho que traz o enredo do romance, sempre contextualizando aspectos ligados à história do Brasil, sem, no entanto, chegar ao didatismo.

Para realizar a passagem à obra de Rubem Fonseca, Raillard traça um paralelo entre o estilo dos dois autores:

Alors que le roman d'Ivan Ângelo avec tous ces artifices formels, est marqué d'un humanisme psychologique, chez Rubem Fonseca, toute psychologie balayée, il s'agit plutôt d'une phénoménologie moraliste. Fragmentation journalistique chez Ivan Angelo, " hyperréalisme », images de publicité chez Fonseca. Le ton est sec. Sur un " monde vieux, qu'il voit ceint de fils de fer barbelés, sur une société qui « n'a pas besoin d'être protégée mais bien détruite », il jette une lumière crue de mirador. (ibidem) ${ }^{29}$

Após essa transição, a autora apresenta O caso Morel como "um falso romance policial", passando então à síntese e breve análise do enredo: "um quadro muito negro de uma sociedade que se arruína" (ibidem). Para Raillard, esse "quadro atinge o mais perfeito estágio" nos contos de Feliz ano novo. Para os contos, os adjetivos são superlativos: superbes, glaçantes. A autora usa nouvelles e não contes, por isso o feminino: "Elas foram proibidas no Brasil. Elas contam a violência latente, o horror e a degradação sórdida. Fonseca corta a carne viva, obtendo fatias de morte..". (ibidem). Esse comentário inicia uma seqüência sucinta

\footnotetext{
28 "Duas obras trazem, cada uma a sua maneira, uma luz sobre o Brasil dos anos 70. Ou, ao menos, sobre certos aspectos de um Brasil dentre tantos Brasis, do qual se fala ou não. O Brasil destes autores tem tons levemente apodrecidos no calor dos trópicos, na amargura dos ideais perdidos e no zumbir da televisão. Barrigas cheias demais ou barrigas vazias..."

29 "Enquanto o romance de Ivan Ângelo, com todos seus artifícios formais, é marcado por um humanismo psicológico, em Rubem Fonseca, é apagada toda psicologia, trata-se mais de uma fenomenologia moralista. Fragmentação jornalística em Ivan Ângelo, 'hiper-realismo', imagens de publicidade, em Fonseca. O tom é seco. Sobre um 'mundo velho' que ele vê cercado por arame farpado, sobre uma sociedade que 'não precisa ser defendida, mas sim destruída', ele joga uma luz crua e fria."
} 
de temas abordados nos contos, como "Feliz ano novo", "Passeio noturno" e "Abril, no Rio, em 1970": "de marginais que dão um golpe, violentam e matam, até o honrado pai de família, maníaco do crime gratuito. Num ritmo de partida de futebol retransmitido pelo rádio, são as esperanças de um jogadorzinho de futebol de bairro, etc." (ibidem).

$\mathrm{Na}$ conclusão, mais elogios são tecidos ao contista Rubem Fonseca, comparando-o a Dalton Trevisan. O vampiro de Curitiba seria traduzido por Geneviève Leibrich e Nicole Biros e publicado pela Editora Métaillé somente em 1998:

Sa concision, sa précision, apparentent Fonseca à cet autre virtuose de la nouvelle qu'est, au Brésil, Dalton Trevisan - que l'on attend toujours de voir publié en France. Comme lui, il se rattache à une tradition de "conteurs" (c'est-à-dire d'auteurs de nouvelles), très forte au Brésil, à laquelle appartiennent aussi des écrivains connus comme romanciers tels que Machado de Assis ou Guimarães Rosa. (ibidem) ${ }^{30}$

A autora esclarece o emprego de "conteur", pois o termo se presta a um jogo de palavras interessante em francês, significando tanto contista como contador de histórias.

Para encerrar seu artigo e citar novamente Ivan Ângelo, a autora emprega novamente o termo "conteur", sem, no entanto, fazer maiores observações: "Contista', também, com certeza, é Ivan Ângelo cuja Festa traz o subtítulo de romance-conto" (ibidem).

Conclui, finalmente, declarando que, "se ambos os autores são testemunhas dos anos 70 e das falhas do desenvolvimento 'à americana', não podem ignorar a ‘tradição' brasileira: uma realidade obstinada, múltipla, violenta e dificilmente reduzível a esquemas de simples teorias" (ibidem).

Deve-se considerar que os leitores dessas publicações, especializadas em literatura, não são completamente leigos. As informações históricas evidenciadas nos dois primeiros artigos, a utilização das mesmas fotos dos escritores sugerem

\footnotetext{
30 "Sua concisão, sua precisão, vinculam Fonseca a este outro grande virtuose da novela que é, no Brasil, Dalton Trevisan - que ainda esperamos ver publicado na França. Como ele, Fonseca está ligado a uma tradição de 'contistas' muito forte no Brasil e à qual pertencem também escritores conhecidos como romancistas tais como Machado de Assis ou Guimarães Rosa."
} 
a realização de um trabalho de informação e lançamento da parte da editora à mídia especializada. Os artigos refletem a política editorial na ocasião do lançamento de Rubem Fonseca na França.

Gérard de Cortanze, além de crítico literário e tradutor, iniciava, na ocasião da publicação de seu artigo, sua carreira de escritor. Após diversos ensaios, livro de poesias e vários romances, recebeu o Prix Renaudot em 2002 por seu romance Assam.

Pode-se claramente notar o imenso arcabouço intelectual de Gérard de Cortanze, tanto no que se refere à complementação das informações, históricas e literárias, fornecidas habitualmente em um dossiê da editora Flammarion, quanto à maestria em sua escrita, atiçando a curiosidade de seu leitor. Gérard de Cortanze tem total familiaridade com o conteúdo do material analisado, pois se refere constantemente ao enredo dos romances e dos contos com detalhes.

As constantes referências a escritores das mais diversas épocas e origens e a conclusão, evocando Dante e Shakespeare, além de reforçar a competência literária do autor, buscam construir vínculos literários que indiquem, ao mesmo tempo que mantêm 0 respeito às identidades culturais específicas, a universalização dos textos literários. O autor defende a leitura crítica das obras.

Quanto a Alice Raillard, não se trata apenas da tradutora de Jorge Amado, José Mauro de Vasconcelos, João Ubaldo Ribeiro e Darcy Ribeiro, e muitos outros. Raillard é uma conceituada crítica literária e ensaísta consagrada, sobretudo, à literatura brasileira.

Por meio desses dois artigos, pode-se constatar que as primeiras traduções de Rubem Fonseca na França foram bem vistas pelos críticos franceses.

Uma vez abortado o projeto editorial da Flammarion, o destino da obra de Rubem Fonseca segue duas vertentes nas décadas de 1980 e 1990: uma diz respeito à publicação de contos em antologias e coletâneas consagradas à prosa curta brasileira ou sul-americana; a outra concerne à publicação de seus romances, de 1986 a 1998.

A edição de 1982 da Revue Europe traz a tradução do conto "O outro" ("L'autre"), realizada por Daisy da Conceição Elísio e Mariangela dos Santos 
Paulo. O referido conto, que originalmente faz parte de Feliz ano novo, já havia sido traduzido por Marguerite Wünscher, tendo sido publicado em francês em 1979 no volume intitulado Le cas Morel suivi de Bonne et heureuse année, pela Flammarion. A Revue Europe, em diversas edições, foi peça importante na intermediação cultural Brasil-França e será foco de análise mais conseqüente no final deste capítulo.

De 1979, data da publicação de seu primeiro romance traduzido, a 1986, quando da publicação do segundo romance em francês, contando com raras publicações em coletâneas, Fonseca já gozava de prestígio internacional, pois figurou na publicação especial de Libération, como comentado anteriormente.

Em 1986, a editora Grasset inicia a publicação dos romances de Rubem Fonseca, todos na tradução de Philippe Billé. O primeiro, de uma série de cinco, é A grade arte (Du grand art). Sucedem-se Bufo \& Spallanzani, em 1989; Vastas emoções e pensamentos imperfeitos (Vastes émotions et pensées imparfaites), em 1990; Agosto (Un été brésilien), em 1993; e O selvagem da ópera (Le sauvage de l'opéra), em 1998.

O tradutor conhecia igualmente o Brasil, porém passou aqui muito menos tempo que Marguerite Wünscher. ${ }^{31}$

Uma pequena publicação de umas 35 páginas, Rio même - souvenirs d'un voyage au Brésil (2002), editada por Pierre Mainard - Bordeaux, nos dá essa informação:

Je séjournai au Brésil un mois et demi, en 1984, de la mi-août au début octobre. Mis à part quelques jours passés à São Paulo peu avant mon retour, je suis resté à Rio de Janeiro, à Rio même, au centre-ville. (Billé, 2002, p.7) ${ }^{32}$

Questionado sobre seu livro, que termina da seguinte maneira:

\footnotetext{
${ }^{31}$ Billé, assim como Marguerite Wünscher, encontrou-se uma vez pessoalmente com Rubem Fonseca. O encontro ocorreu em março de 1987, em Paris.

32 "Estive no Brasil um mês e meio, em 1984, da metade de agosto ao início de outubro. Fora alguns dias passados em São Paulo, pouco antes de meu retorno, fiquei no Rio mesmo, no centro da cidade."
} 
Du jour où j'ai pris la décision de quitter le pays, la mélancolie, qui jusqu'alors avait dominé mon esprit, se dissipa peu à peu. Comme si le simple fait de savoir que j'allais bientôt abandonner ces lieux était la meilleure façon, ou la seule, dans ces circonstances, de me les rendre supportables, tout ce qui m'entourait me sembla plus aimable. (ibidem, p.38) ${ }^{33}$

\section{Philippe Billé declarou "mon voyage de 1984 au Brésil était un peu triste. J'étais}

tout seul, je m'ennuyais. Mais je n'en garde pas un si mauvais souvenir". ${ }^{44} \mathrm{E}$ continua:

Lorsque j'ai traduit quatre contes de RF au début des années 80 (1982? 3?) je ne connaissais pas A grande arte ni d'autre roman de lui. Je voulais faire publier ses nouvelles, qui me plaisaient. En août 84 , en voyage à Rio, un ami me fit découvrir le roman A grande arte et me suggéra de le faire publier en français. J'ai traduit un échantillon et j'ai fait part de mon projet à l'agent littéraire Carmen Balcells, à Barcelona, qui l'a transmis aux éditions Grasset. A l'époque j'ignorais que Grasset projetait de publier ce livre. Ma proposition leur est parvenue au moment où ils avaient déjà acheté les droits du livre mais pas encore engagé un traducteur. J'ai donc eu la chance d'être engagé par les éditions Grasset (à l'époque, c'était François Bourrin qui s'occupait de la publication de Fonseca). Ensuite les éditions Grasset m'ont fait traduire plusieurs romans de RF, que je trouvais moins intéressants que ses nouvelles. J'ai proposé la traduction de nouvelles de RF mais Grasset n'en a jamais voulu. J'ai traduit Vastas emoçoes... sans interroger l'auteur, il en fut de même peut-être pour O selvagem da ópera, je ne me souviens plus, en tout cas je n'ai pas de courrier à ce sujet. (sic) ${ }^{35}$

$\mathrm{Na}$ ocasião do lançamento da tradução francesa de $A$ grande arte, em 1986, sete anos após o lançamento da tradução do primeiro romance de Rubem

\footnotetext{
33 "No dia em que tomei a decisão de deixar o país, a melancolia que até então havia dominado meu espírito se dissipou pouco a pouco. Como se o simples fato de saber que eu ia em breve abandonar esse lugar fosse a melhor forma, ou a única, nessas circunstâncias, de torná-lo suportável, tudo ao meu redor me parecia mais simpático."

34 "minha viagem de 1984 ao Brasil foi um pouco triste. Eu estava só, me aborrecia. Mas não guardo uma lembrança tão ruim dela. "Informação obtida via e-mail, em 19.4.2006.

35 "Quando traduzi quatro contos de RF no início dos anos 80 (1982? 3?) eu não conhecia nem A grande arte, nem nenhum outro romance dele. Eu queria publicar seus contos, que me agradavam. Em agosto de 1984, em viagem ao Rio de Janeiro, um amigo me fez descobrir o romance A grande arte e me sugeriu publicá-lo em francês. Traduzi uma amostra e comuniquei meu projeto à sua agente literária Carmen Balcells, em Barcelona, que o transmitiu às edições Grasset. Na época eu ignorava que Grasset tinha o projeto de publicar esse livro. Minha proposta chegou a eles no momento em que eles já haviam comprado os direitos do livro, porém ainda não haviam contratado um tradutor. Tive então a sorte de ser contratado pelas edições Grasset (na época, era François Bourrin que cuidava da publicação de Fonseca. Em seguida, as edições Grasset me fizeram traduzir diversos romances de RF, que considerei menos interessantes que seus contos. Propus a tradução dos contos mas Grasset nunca quis. Traduzi Vastas emoções sem consultar o autor, talvez tenha acontecido o mesmo com O selvagem da ópera, não me lembro mais, em todo caso, não tenho correspondência a esse respeito." Informação obtida via e-mail 4.10.2005.
} 
Fonseca para a língua francesa, pouco se fala sobre o autor brasileiro. Três pequenos artigos, no entanto, parecem resumir o romance de Fonseca e seu estilo como romancista. Todos evidenciam os ingredientes próprios ao romance policial: assassinatos em série, prostitutas, tráfico de drogas, pistas em vídeo...

O primeiro, "Mandrake à Rio", aparece no Figaro Littéraire em 16 de junho, assinado por B. Charpentier (1986). São apenas dois parágrafos que inicialmente resumem o enredo de $A$ grande arte salientando a figura de Mandrake, o personagem advogado-detetive, sua descontração e seu lado engraçado, e, evidentemente, os ingredientes de todo romance policial já citados como elementos que "rapidamente lançam a intriga." Um defeito é então salientado: "a insistência de Fonseca em rechear sua narração com referências culturais exibicionistas por demais que, em vez de servirem à ação, frequentemente apenas a tornam mais pesada". Charpentier ainda sugere que Rubem Fonseca, "um dos mais célebres escritores brasileiros contemporâneos, parece querer travestir, camuflar, seu romance policial em fantasia de intelectual". O autor acrescenta que, apesar de se tratar de um livro agradável, o gênero não é explorado por completo. Sugere, finalmente, como leitura de passatempo "A lire dans le train" (ibidem). Os dados catalográficos do romance são dados no final do artigo.

O segundo pequeno artigo "Fonseca: les bas-fond de Rio" aparece no Le Point, rubrica "Suspense", em 23 de junho, e é assinado por Philippe Nourry (1986), jornalista e escritor. Após o título, aparecem as indicações da publicação do romance. Já nas primeiras linhas, o teor desse artigo de dois parágrafos é bem diferente do precedente: "Voilà du polar chic qui ne manque pas de ton" (ibidem) Após o enaltecimento do livro como um romance policial chique e bem enquadrado nesse gênero, surgem os comentários sobre os indispensáveis ingredientes do romance policial enriquecidos pelo "movimento de alegria e vivacidade extremas". Segue uma saudação a Hammet e a Chandler. Nourry declara que Fonseca se diverte e o leitor também. $\mathrm{O}$ articulista atenta para a série de referências e pastiches que servem para despertar a curiosidade dos leitores. Faz também menção ao aspecto cinematográfico da obra. Conclui citando o escritor mexicano Carlos Fuentes e sua obra $A$ cabeça da Hidra, declarando que 
um thriller pode servir a ambições maiores que o simples divertimento, pois há nele uma ruse littéraire, e que certamente Rubem Fonseca segue, com sucesso, o mesmo caminho de Fuentes e de outros escritores latino-americanos.

O terceiro artigo faz parte de uma rubrica intitulada "Sélection - Sous le parasol les pages" do L'Express; é da autoria da crítica, editora e escritora de romances policiais Noëlle Loriot (1986) e consta do exemplar da primeira semana de agosto. As indicações bibliográficas figuram no início e não há título. Trata-se de um único parágrafo que de certa forma confirma os comentários do artigo precedente:

Ce brésilien considère le polar comme um exercice littéraire tout à fait sérieux, sans, pour autant, négliger les règles du genre. Rio de Janeiro, comme toile de fond, un assassin de prostituées, une avalanche de suspects, du milliardaire au clochard, et un avoc travesti en privé. Mais l'enquête n'est ici qu'un fil conducteur fragile, puisque le «cher maître » lui-même serait incapable de parier sur sa propre innocence. Un jeu au second niveau de l'art. ${ }^{36}$

No lançamento da tradução de Bufo \& Spallanzani, em 1989, outros três artigos se destacam na mídia especializada. O primeiro "Meurtre à deux visages" de Jean-François Fogel (1989) (jornalista e escritor), aparece em janeiro, no Le Point, rubrica "Livres - roman". Entre o título e o corpo do artigo há um lead: "O homicídio progrediu desde Chandler... Rubem Fonseca escreveu um romance policial no qual se mata por convenção, para em seguida rir das convenções" (ibidem).

Fogel viu na francofilia de Rubem Fonseca, no pseudônimo da personagem Gustavo Flávio, referência explícita a Gustave Flaubert, um excelente "gancho" para realizar seu ofício. E é justamente citando o escritor Mario Vargas Llosa e sua obra sobre Madame Bovary, A orgia perpétua, que inicia seu artigo. Diz ele:

\footnotetext{
36 "Este brasileiro considera o romance policial como um exercício literário bem sério, sem, no entanto, negligenciar as regras do gênero. Rio de Janeiro como pano de fundo, um assassino de prostitutas, uma avalanche de suspeitos, do bilionário ao mendigo, e um advogado travestido em detetive. Mas a investigação é aqui apenas um fio condutor frágil, já que até mesmo o 'caro mestre' seria incapaz de apostar em sua própria inocência. Um jogo em segundo grau no qual o autor eleva o ridículo ao nível da arte."
} 
Il n'y a que les Latino-Américains pour lire Flaubert au pied de la lettre. Le Péruvien Mario Vargas Llosa a signé le meilleur essai sur " Madame Bovary » pour s'être justement plié à la discipline recommandée par son créateur: " une orgie de lecture ». Voici maintenant un Brésilien, Rubem Fonseca, qui n'ouvre pas en vain «Le dictionnaire des idées reçues». Flaubert y note: "Il y a des romans écrits avec la pointe d'un scalpel. Ex. : « Madame Bovary ». » Fonseca, 60 ans, francophile, francophone, flaubertien, n'hésite pas: dans une scène finale affolante, et après avoir écrit de la pointe d'une plume de vif-argent, il émascule le héros de « Bufo \& Sapallanzani ».

Le malheureux, qui est écrivain, a pris pour pseudonyme le nom Gustavo Flavio, en hommage à qui nous savons. Séducteur forcené, il avouait au tout début du livre n'avoir jamais compris Flaubert quand il disait: «Réserve ton priapisme pour le style, foutre ton encrier... » C'est dire avec quelle sévérité Rubem Fonseca sanctionne une leçon flaubertienne mal assimilée. (ibidem) ${ }^{37}$

O autor compreende que Fonseca o faz "à sua maneira, com um assassinato num assassinato, uma história de homicídio que esconde uma estória bem negra". Para ele, essas são características de um romance policial pósmoderno no qual se mata por convenção para depois rir das convenções. Daí a explicação da "justaposição de duas maneiras nesse livro singular". Uma face oferece uma história profundamente violenta, outra face está cheia de "referências, astúcias, mudanças de pontos de vista, zombando da visão onisciente do criador de ficção". O resultado é uma salada inesperada que contempla todo tipo de gênero. No entanto, Fogel ressalta que Fonseca vacila quando a história sai da cidade, declarando que "assim que um livro traduz preocupações em fatos minúsculos, deseja-se que suas personagens sejam esquecidas e isto significaria esquecer a evolução do assassinato em algumas décadas" (ibidem).

\footnotetext{
37 "Só mesmo os latino-americanos para ler Flaubert ao pé da letra.O peruano Mario Vargas Llosa assinou o melhor ensaio sobre 'Madame Bovary' por ter-se justamente dobrado à disciplina recomendada por seu criador: 'uma orgia de leitura'. Eis agora um brasileiro, Rubem Fonseca, que não abre em vão 'O dicionário das idéias feitas'. Flaubert nele diz: 'Há romances escritos com a ponta de um escalpelo. Ex: 'Madame Bovary'.' Fonseca, 60 anos, francófilo, francófono e flaubertiano, não hesita: numa cena final estupenda e após te escrito com a ponta impetuosa de sua pena, ele emascula o herói de 'Bufo \& Spallanzani'.

O infeliz, que é escritor, assumiu como pseudônimo o nome de Gustavo Flávio, em homenagem a quem nós sabemos. Sedutor desenfreado, ele confessava bem no início do livro jamais ter compreendido Flaubert quando este dizia: 'Reserve teu priapismo para o estilo, foda teu tinteiro...' Para se ver com que severidade Rubem Fonseca sancionava uma lição flaubertiana mal assimilada."
} 
Pour Chandler, auteur moderne, le meurtre était, selon son expression si juste, le repos gommant toutes les lassitudes des vivants. Chez Rubem Fonseca, auteur post-moderne, il est devenu leur unique porte de sortie. (ibidem) $^{38}$

"Le chaos de Rubem Fonseca", também de janeiro, está nas "Lettres étrangères" do Le Monde, e é assinado pelo jornalista e escritor Patrick Kechichian (1989). O autor emprega, ao iniciar seu artigo, um ritmo tão estonteante quanto o livro que descreve como "histoire endiablée". Combinando os tão famosos ingredientes do romance policial, Kechichian, em paralelo ao Gustavo Flávio de Fonseca, definirá o policial Guedes como "um tipo de Javert com rosto magro e olhos amarelos". Uma vez elogiado o romance ao ser comparado aos grandes modelos do romance negro americano, embora de forma bastante irônica quando compara Nova York ao Rio de Janeiro, o ritmo e a energia característicos logo são, segundo o autor, comprometidos por culpa das influências francesa e européia de Fonseca, tornando-se densamente didáticas, apesar do humor e da ironia:

Dans ses meilleurs moments, Bufo \& Spallanzani peut faire songer aux grands modèles du roman noir américain, Rio valant bien New-York pour ce qui est de la criminalité. Mais l'auteur, nourri de littérature française (les initiales de Gustavo Flavio sont aussi celles de Flaubert) et européenne, s'égare trop souvent dans les méandres de son récit, qui perd alors de son rythme et de sa vivacité. L'ironie et l'humour des digressions ne les empêchent pas d'être lourdement didactiques. (ibidem) ${ }^{39}$

E apesar de concordar com a afirmação do autor brasileiro de que "O escritor deve ser essencialmente um subversivo", Kechichian atenta para o risco

\footnotetext{
38 "Para Chandler, autor moderno, o assassinato era, segundo sua expressão tão justa, o repouso apagando todos os desgostos dos vivos. Em Rubem Fonseca, autor pós-moderno, ele tornou-se sua única porta de saída."

39 " $E \mathrm{Em}$ seus melhores momentos, Bufo \& Spallanzani pode fazer pensar nos grandes modelos do romance noir americano, Rio equiparando-se a New York, em termos de criminalidade. Mas o autor alimentado pela literatura francesa (as iniciais de Gustavo Flávio são também as de Flaubert) e européia, se perde com freqüência nos meandros de sua narrativa, que perde então seu ritmo e sua vivacidade. A ironia e o humor das digressões não as impedem de ser enfadonhamente didáticas."
} 
do exagero da subversão da forma romanesca: o tédio sem formas. E declara que o romance muitas vezes não consegue escapar dessa situação.

O conteúdo do artigo "Glouglous baroques à Rio", publicado em abril do mesmo ano, de autoria de Dominique Durand (1989) para a rubrica "Lettres ou pas Lettres" em Le Canard Enchaîné, faz jus à irreverência do título e à reputação do periódico: Journal satirique paraissant le mercredi. Um desenho ilustra o artigo: um sapo ao lado de um tinteiro diz: "J'aime les récits quelque peu crapuleux". Assim, além da onomatopéia do título referente aos anfíbios anuros, "glouglou", estabelece-se pela declaração do batráquio (sapo = crapaud em francês) um jogo de palavras fonético com o termo crapuleux, que significa imoral, baixo, desonesto. Dessa forma, título, ilustração, ou seja, todo o aparato visual inicial conduz o leitor ao título do romance (e por que não dizer, ao teor de seu conteúdo também): o sapo Bufo marinus e o biólogo Spallanzani, embora Durant comente que houve uma licença poética de Fonseca, pois as experiências do cientista italiano se referiam a salamandras e não a sapos: "com efeito, eram salamandras, mas o autor de ficção tem todos os direitos, como não pára de nos lembrar Fonseca" (ibidem).

Entre o título e o texto aparece apenas o título do livro, o autor e a editora. Apesar do tom satírico, esse parece ser, no que diz respeito à crítica francesa de Fonseca, um dos artigos mais elogiosos e comprometidos com o ato da escrita literária e dialoga com o artigo de Florent Kohler:

Deux citations, pour résumer l'atmosphère de cet étonnant bouquin d'un avocat écrivain brésilien, aussi irracontable que les petits polars métaphysiques que concoctaient en Argentine les compères Borges et Bioy Casares :

«Écrire est une expérience pénible, épuisante, c'est pourquoi, parmi les écrivains, il y a tant d'alcooliques, de drogués, de suicidaires, de misanthropes, de fugitifs, de fous, de malheureux, de morts jeunes et de vieux gagas. " (La traduction du portugais est de Philippe Billé).

L'écriture, primo. Elle obsède au plus haut point le narrateur de ce gymkhana initiatique à travers les faubourgs de Rio de Janeiro, l'écrivain Gustavo Flávio, ainsi pseudo-nommé en hommage à Gustave Flaubert, celui 
qui disait à l'écrivain de toujours qu'il faut «foutre ton encrier». (Durand, $1989)^{40}$

No trecho citado, Durand introduz a obra por meio da apresentação do escritor. Se, por um lado, o paratexto editorial normalmente enfatiza a biografia de Fonseca, os artigos nem sempre evidenciam seu percurso. Aqui, surge en passant a informação da profissão do autor brasileiro e não será gratuita, pois o crítico retoma a informação em sua conclusão como se verá mais à frente. O conteúdo principal, no entanto, já tem como alvo o ato de escrever. Essa será a tônica ao longo do artigo, que continua utilizando as referências presentes no próprio texto de Rubem Fonseca:

D'ailleurs, au début du livre, alors que le cadavre de Delfina apparemment suicidée - se trouve dans sa berline, rue Diamantina, Gustavo, qui a promis à son éditeur un «Bufo \& Spallanzani » a un horrible cauchemar où Tolstoï, faisant mine de tremper une plume dans un encrier, lui dit : "Pour écrire « Guerre et Paix », j'ai fait ce geste deux cent mille fois ». (ibidem) ${ }^{41}$

Outro aspecto a ser comentado é o estilo especular de Dominique Durand, que faz uso do vocabulário gírio e cotidiano, assim como Rubem Fonseca em sua narrativa:

Gustavo avait une liaison très glu avec Delfina, grande bourgeoise dans l'ennui le plus total. II est donc normal que le flic Guedes, crade sur lui mais très clean dans sa tête, le soupçonne. Et puis, ça ferait très bien dans le roman.

Ah! j'allais oublier la seconde citation clé : « A quoi bon continuer à vivre si on ne peut plus avoir la queue dure ? " La métaphysique du macho brésilien a besoin d'une assise souève, haletante, et si possible féminine. Comme Minolta, une hippie rêveuse, en compagnie de qui il fera l'expérience de se zombifier après avoir avalé un zeste de venin du célèbre crapaud tueur Bufo marinus, celui-là même qui intéressait tant le biologiste de Pavie,

\footnotetext{
40 "Duas citações para resumir a atmosfera deste livro surpreendente de um advogado escritor brasileiro, tão pouco contável quanto os pequenos romances policiais metafísicos arquitetados na Argentina pelos companheiros Borges et Bioy Casares:

«Escrever é uma experiência penosa, é por isso que entre os escritores há tantos alcoólatras, drogados, suicidas, misantropos, fugitivos, loucos, infelizes, mortos prematuros e velhos gagas » L'écriture, primo. A escrita em primeiro lugar.É a obsessão ao mais alto nível do narrador dessa gincana iniciática através das ruas do Rio de Janeiro, o escritor Gustavo Flávio, pseudônimo em homenagem a Gustave Flaubert, aquele que dizia ao escritor que era preciso sempre 'foder seu tinteiro'."

41 "Aliás, no começo do livro, enquanto o cadáver de Delfina - que aparentemente cometeu suicídio - está dentro de seu carro, na Rua Diamantina, Gustavo que prometeu a seu editor um «Bufo \& Spallanzani » tem um horrível pesadelo no qual Tolstoi, fingindo mergulhar uma pluma num tinteiro, Ihe diz: 'Para escrever 'Guerra e Paz', fiz este gesto duzentas mil vezes."
} 
Sapallanzani (en fait, il s'agissait de salamandres, mais l'auteur de fiction a tous les droits, ne cesse de nous rappeler Fonseca), qui grillait les pattes du mâle pendant qu'il râlait de jouissance durant son interminable coït avec sa gente crapaudine. (Durand, 1989) ${ }^{42}$

Com muito bom humor, ironia, o crítico vai mesclando o enredo do romance, sempre se referindo a passagens que se relacionam com a literatura e o processo de criação literária:

Il sera question de ce Bufo et d'autres choses affreuses lors d'une retraite mouvementée au refuge du Pic de l'Epervier, où Gustavo se rend, en compagnie d'une bande de cinglés dépareillés mais assez lubriques, pour écrire son, justement, roman, dont le titre est indiqué ci-dessus. Dans un chapitre de qualité, où Fonseca pastiche élégamment Agatha Christie (un groupe de gentlemen et women, dans un lieu clos, s'épient, font des jeux autour du feu, se haïssent, veulent tous se sauter, et il y a un meurtre poue le dessert), il a une grande discussion avec un odieux chef d'orchestre imbu, sur "De l'utilité des livres ». Pour les punir, il leur donne à tous un devoir à faire ; où l'on retrouve l'utilité métaphysique et tout simplement psychologique de la bave du crapaud sur les blanches et stupides colombes. Bravo, maestro ! (je ne pratique pas le brésilien dans l'enthousiasme littéraire). (Durand, 1989) ${ }^{43}$

O articulista conclui o artigo, afinal, dizendo que a literatura é o verdadeiro assunto do livro. Retoma então a informação sobre a profissão de Fonseca para justificar seu enciclopedismo. Justifica igualmente o final do romance, "frouxo", como todo final de romance:

\footnotetext{
42 "Gustavo tinha uma relação muito obscura com Delfina, grã-fina mergulhada no maior tédio. É normal que o tira Guedes, meio porcalhão mas muito clean de cabeça, suspeite dele. E, além disso, cairia muito bem no romance.

Ah! Eu ia esquecendo a segunda citação-chave: 'Do que vale a vida se não se pode ficar de pau duro?' A metafísica do machão brasileiro precisa de uma base suave, ofegante, e se possível feminina. Como Minolta, uma hippie sonhadora, na companhia de quem ele fará a experiência de se zumbificar após ter engolido uma raspa de veneno do famoso e nocivo sapo Bufo marinus, aquele mesmo que tanto interessava ao biólogo de Pávia, Spallanzani (com efeito, eram salamandras, mas o autor de ficção tem todos os direitos, como não pára de nos lembrar Fonseca), que grelhava as patas do macho enquanto gemia de gozo durante seu interminável coito com sua gentil sapinha.

43 "Trata-se desse Bufo e de outras coisas horríveis durante um movimentado retiro no Pico do Gavião, onde Gustavo vai, em companhia de um bando heterogêneo de doidões, mas bastante lúbricos, para escrever, justamente, seu romance, cujo título está indicado acima. Em um capítulo de qualidade no qual Fonseca também faz um pastiche de Agatha Christie (um grupo de homens e mulheres, em um lugar fechado, espiam-se, jogam em torno da lareira, odeiam-se, querem todos transar, e há um assassinato como sobremesa) ele tem uma grande discussão com um odioso maestro sobre 'Da utilidade dos livros'. Para puni-los, ele lhes dá, a todos, uma lição a ser feita: qual seria a utilidade metafísica e simplesmente psicológica da baba do sapo sobre as brancas e estúpidas pombas. Bravo, Maestro! (Não pratico o português no entusiasmo literário)."
} 
L'amour de la littérature est en fait le vrai sujet de ce livre, enchâssé dans le grotesque et le stupre et le baroque comme de purs cristaux dans une gangue granitique servant de bordure pour un trottoir de l'avenue Copacabana. Par surcroît, en bon avocat, Fonseca nous met dans sa poche en faisant impromptu des citations en français, dont il dit drôlement que "c'est peut-être une langue morte mais elle est belle et elle fonctionne très bien avec les bourgeoises ». Puis il finit son roman, "mollement», parce qu'ainsi se termine tout roman, cette chose difficile écrite pour un lecteur qui « ne sait pas ce qu'il veut », sauf, bien sûr, des "choses toutes nouvelles, différentes de ce qu'il est habitué à consommer ». Voilà pourquoi sans doute il y a tant de romans français en tête des classements hebdomadaires par étapes. (ibidem) $^{44}$

Surpreendentemente, o último parágrafo tem ares de publicidade, convidando o leitor a consumir Bufo \& Spallanzani:

Pour une narration dévergondée, une sexualité effrénée mais sans risques, une réflexion ardemment désabusée sur l'utilité des livres, et pour un texte épatant, physique et même pataphysique, faites comme le Bufo marinus : plongez-vous dans « Bufo \& Spallanzani »! (ibidem) ${ }^{45}$

Vastes émotions et pensées imparfaites (Vastas emoções e pensamentos imperfeitos) parece ocupar menos a crítica especializada. ${ }^{46}$

Paralelamente à publicação dos romances, registra-se, em 1989, a publicação de "Constat", em tradução de Luiz Carlos de Brito Rezende, na Lettre Internationale n.20. ${ }^{47}$ Outros contos de Rubem Fonseca figuram em antologias publicadas na França nos anos 1990. É o caso de "Gazela", publicado como "Gazelle" em tradução de Lyne Strouc na Anthologie de la nouvelle latinoaméricaine, em 1991. Em Menaces - Anthologie de la nouvelle noire et policière

\footnotetext{
44 "O amor pela literatura é efetivamente o tema desse livro, engastado no grotesco, na luxúria e no barroco como puros cristais numa ganga de granito, servindo de debrum para a calçada de Copacabana. Ainda por cima, como bom advogado, Fonseca nos conquista fazendo, quando menos se espera, citações em francês, das quais diz gracejando que 'talvez seja uma língua morta, mas é bela e funciona muito bem com as burguesas'. Depois, ele termina seu romance, 'languidamente', porque assim se termina todo romance, esta coisa difícil escrita para um leitor que 'não sabe o que quer', salvo, evidentemente, 'coisas totalmente novas, diferentes do que ele está habituado a consumir'. Eis porque, sem dúvida, há tantos romances franceses no topo das listas semainais dos livros mais lidos."

45 "Para se apreciar uma narração desavergonhada, uma sexualidade desenfreada, mas sem riscos, uma reflexão ardentemente desabusada sobre a utilidade dos livros, e um texto estupendo, físico e mesmo patafísico, faça como o Bufo marinus : mergulhe em " Bufo \& Spallanzani »!"

${ }^{46}$ Não se teve acesso a nenhum artigo referente ao lançamento desse romance na França.
} 
latino-américaine, foi publicado em 1995 "Relatório de ocorrência em que qualquer semelhança não é mera coincidência", traduzido como "Compte rendu de circonstances où toute ressemblance n'est pas pure coïncidence", por JeanClaude Vignol. Curiosamente, o conto "O outro" foi alvo de nova tradução, por parte de Jacques Thiériot, em 1997, publicado na antologia Contes de Noël brésiliens.

Em 1998, na ocasião do lançamento de Le sauvage de l'Opéra, dois artigos merecem destaque, pois desenham bem os dois comportamentos característicos da crítica fonsequiana. Ambos datam de março do mesmo ano.

Em "Rubem Fonseca, amour et douleur", Aliette Armel (1998) comenta para o Magazine Littéraire a publicação do último romance de Rubem Fonseca traduzido para o francês, $O$ selvagem da ópera. A crítica dá ao leitor um panorama da obra traduzida de Fonseca:

Les cinq romans de Rubem Fonseca, déjà publiés en France et traduits par Philippe Billé, donnaient une vision décapante de la société brésilienne contemporaine (en particulier Un été brésilien, éd. Grasset, 1993), à travers des ouvrages à la limite du roman noir, parfois conçus comme des thrillers (Du Grand Art, éd. Grasset, 1986), avec des intrigues ravageuses mêlant le sexe, la violence, la folie autour d'un curieux personnage d'écrivain (Bufo \& Spallanzani, éd. Grasset, 1989). Vastes émotions et pensées imparfaites (éd. Grasset, 1986) montrait un personnage de scénariste poursuivi par des voleurs de pierres précieuses alors qu'il faisait de fréquents allers et retours entre Rio et Berlin pour récupérer un manuscrit d'Isaac Babel. (Armel, 1998, p.97) $)^{48}$

Vale observar o destaque que a articulista dá a Un été brésilien. Após esse breve resumo, Armel passa a explorar a figura do advogado Fonseca como escritor, exaltando seu estilo brilhante que mescla arte e suspense, o estudo da

\footnotetext{
${ }^{47}$ Esse foi um dos raros textos a que não se teve acesso neste estudo.

48 "Os cinco romances de Rubem Fonseca, já publicados na França e traduzidos por Philippe Billé, davam uma visão despojada da sociedade brasileira (em especial Agosto, Grasset, 1993), através das obras no limiar do romance noir, às vezes concebidas como um triller ( $A$ grande arte, Grasset, 1986), com intrigas devastadoras que misturam sexo, violência e loucura em torno de uma curiosa personagem de escritor (Bufo \& Spallanzani, éd. Grasset, 1989). Vastas emoções e pensamentos imperfeitos (Grasset, 1986) mostrava um personagem de roteirista perseguido por ladrões de pedras preciosas, enquanto ele fazia freqüentes idas e vindas entre Rio e Berlim para recuperar o manuscrito de Isaac Babel."
} 
sociedade e da história brasileira e suas referências culturais. Os elogios continuam quando a autora do artigo passa ao enredo do romance:

Le sauvage de l'opéra occupe dans ses œuvres une place à part. II ne s'agit plus ici de mettre en scène un écrivain ou un scénariste mais de présenter le texte de base d'un film "qui raconte la vie d'un homme qui a réellement existé » et qui "doit être écrit avec beaucoup d'informations, et selon une structure flexible » où sont rappelés sans cesse les mouvements de la caméra ou les raisons de l'insistance sur tel ou tel geste (comme le cigare qu'allume sans cesse le héros, Carlos Gomes, qui finira par mourir comme Puccini, son ami et rival, d'un cancer à la gorge). (ibidem, p.98) ${ }^{49}$

$\mathrm{O}$ artigo continua e termina ainda louvando tanto o romance quanto a vida de Carlos Gomes.

No segundo artigo, assinado por Raphaëlle Rérolle (1998) para o Le Monde, "Un livret sans musique", o lead já dá o tom à crítica: "Dans cette histoire d'un compositeur d'opéra oublié, Rubem Fonseca mêle différents genres pour former un édifice à la fois intéressant et décevant". ${ }^{50}$

Rérolle construirá seu artigo seguindo sempre o binômio interessante/decepcionante. Dessa forma, os adjetivos se intercalarão entre, por exemplo, surpreendente/entediante, até o desfecho em forma de tropeço: "Fonseca s'était pris lui-même les pieds dans le tapis".

É curioso mencionar que após as indicações catalográficas da obra, um pequeno parágrafo resume a biografia de Rubem Fonseca de forma bastante instigante:

Dans son pays, on l'a surnomé «la Greta Garbo des lettres brésiliennes » pour son obstination à fuir les journalistes. Né le 11mai 1925 à Juiz de Fora (Minas Gerais), Rubem Fonseca a fait des études de droit, puis a exercé divers métiers avant de se consacrer à la littérature. Auteur de

\footnotetext{
49 “O selvagem da Ópera ocupa em suas obras um lugar à parte. Não se trata mais aqui de colocar em cena um escritor ou um roteirista, mas de apresentar o texto de base de um filme 'que conta a vida de um homem que realmente existiu' e que 'deve ser escrito com muitas informações e segundo uma estrutura flexível' onde são lembrados, constantemente, os movimentos da câmera ou as razões da insistência sobre este ou aquele gesto (como o charuto que acende sem parar o herói, Carlos Gomes, que acabará morrendo de um câncer de garganta, como Puccini, seu amigo e rival)"

50 "Nessa estória sobre um compositor de ópera esquecido, Rubem Fonseca mescla diferentes gêneros para construir um edifício, ao mesmo tempo, interessante e decepcionante."
} 
plusieurs romans policiers à grand succès, il est l'un des écrivains brésiliens les plus traduits à l'étranger. (ibidem) ${ }^{51}$

Em Des nouvelles du Brésil publicou-se "O balão fantasma", em 1998, como "Le balon fantôme", na tradução de Philippe Billé.

Em 2004, uma pequena publicação que reúne textos sobre cidades, intitulada Le goût de Rio de Janeiro, da coleção "Le goût des villes", traz um trecho extraído do romance Un été brésilien (Agosto). O trecho contém a descrição da Confeitaria Colombo.

Na edição de 2005 da Revue Europe, publica-se o conto "Almoço na serra no domingo de carnaval" na tradução de Florent Kohler, com o título de "Déjeuner à la montagne un dimanche de carnaval".

\section{Revue Europe: a imagem do Brasil em três momentos}

Como foi citado anteriormente, a Revue Europe foi, em diversos momentos no século $X X$, intermediária entre Brasil e França. Destaca-se a presença do Brasil em três edições da Revue Europe, conceituada publicação mensal existente desde 1923. Rubem Fonseca figura em duas dessas edições. Essas publicações merecem, no presente estudo, comentário mais aprofundado.

Três números (599, em 1979; 640/641, em 1982 e 919-920, em 2005) foram especialmente dedicados à literatura brasileira. A edição 599, de 1979, Le Modernisme brésilien, como o nome indica, trata especificamente do modernismo na literatura brasileira, enfatizando a poesia e os manifestos, a prosa de Mário de Andrade, as artes plásticas e a música. As outras duas publicações buscam dar um panorama da literatura brasileira contemporânea, referindo-se constantemente à sua história literária e à busca da identidade literária nacional. A publicação é direcionada a um público misto, tanto de conhecedores quanto de curiosos de

\footnotetext{
51 'Em seu país, apelidaram-no de 'a Greta Garbo das letras brasileiras' por sua obstinação em fugir dos jornalistas. Nascido em 11 de maio de 1925, em Juiz de Fora (Minas Gerais). Rubem Fonseca estudou direito, depois exerceu diversas profissões, antes de se dedicar à literatura. Autor
} 
literatura ou do Brasil. O teor dos textos vai, portanto, da apresentação da literatura em questão e de seus autores a ensaios, embora curtos, mais profundos. Se a primeira edição dedicada ao Modernismo traz especialistas de renome, há diversidade igualmente na seleção de colaboradores nas duas últimas edições, revelando articulistas e tradutores oriundos dos mais distintos universos, mas que têm no Brasil e na literatura um foco de interesse especial.

A Revue é sempre composta por duas grandes partes: a primeira traz um dossiê específico que tem quatro a cinco módulos, e a segunda parte dá conta da atualidade literária em geral. Nessa segunda parte encontram-se rubricas que pouco variam nas três edições aqui comentadas: "Dires et débats" (1979) / "Cahier de création" (1982-2005) / "Chroniques" (1979-1982-2005) / "Notes de lecture" (2005), não havendo, em princípio, vínculo temático entre o dossiê especial e a segunda parte.

O conteúdo da primeira parte da Revue respeita a seguinte organização: um primeiro módulo apresenta uma pequena introdução do organizador do dossiê principal e um texto representativo da literatura em questão; em seguida, textos literários traduzidos se mesclam com ensaios em três ou quatro módulos. $\mathrm{Na}$ edição de 1982 não há subtítulos nos módulos; podemos, entretanto, destacar aspectos de sua homogeneidade. Já na edição de 2005, os quatro módulos apresentam subtítulos ao dossiê "Littérature du Brésil". Observemos melhor cada uma das publicações.

Em 1982, Serge Bourjea, na época professor no Rio de Janeiro, é encarregado da organização da publicação. Após uma breve introdução do organizador "Une littérature sous les tropiques", um trecho da autobiografia de Jorge Amado, que acabara de completar cinqüenta anos de atividade literária, abre o volume. No primeiro grande módulo há quatro ensaios sobre literatura brasileira. O segundo módulo trata da poesia brasileira. O terceiro módulo trata da prosa contemporânea curta e evidencia autores a partir da terceira geração modernista. É nesse quarto e último módulo do dossiê, entre cinco ensaios e seis

de diversos romances policiais de grande sucesso, ele é um dos escritores brasileiros mais traduzidos no estrangeiro." 
outros textos traduzidos que se encontra a tradução do conto "O outro", de Rubem Fonseca. Não há ensaio específico consagrado ao autor, apenas uma pequena apresentação que antecede o conto em si:

Romancier et auteur de contes. A publié de 1963 à 1981, avec un succès croissant: Os Prisioneiros, A Coleira do Cão, Lucia McCartney, $\mathrm{O}$ Homem de Fevereiro ou Março (Anthologie), O Caso Morel e Feliz Ano Novo. Nous donnons ici la taduction d'un conte très représentatif d'une écriture de la "désintégration sociale" et de la vie des grandes villes brésiliennes. (Europe, 1982, p.118) ${ }^{52}$

Não consta dessa pequena introdução O cobrador, de 1979, tampouco a informação de que $O$ caso Morel, seu único romance até aquele momento, e Feliz ano novo já tinham sido traduzidos para a língua francesa. Os outros autores traduzidos são Clarice Lispector, Murilo Rubião, Dalton Trevisan, Guilherme de Figueiredo, Marina Colasanti e Carlos Eduardo Novaes. O tom desse último bloco é de novidade e contemporaneidade, em contraponto à abertura em que figura o canônico Jorge Amado.

Em 2005, encerrando as festividades do "Ano do Brasil na França", um novo número, organizado pelos professores Michel Riaudel e Pierre Rivas, reconhecidos pesquisadores das relações literárias franco-brasileiras. Como de hábito, há uma introdução assinada por ambos. A tradução inédita de "Instinto de nacionalidade", de Machado de Assis, é o texto escolhido para abrir o volume.

Segue-se um módulo intitulado "État des lieux" com nove ensaios que buscam estabelecer um panorama da literatura brasileira, sempre atentando para o contexto contemporâneo.

Nos três primeiros artigos dessa parte, consagrados à prosa brasileira, Rubem Fonseca terá destaque. O primeiro artigo a mencionar Rubem Fonseca na mais recente edição da Revue Europe é "Panorama de la prose brésilienne". O autor, Manuel da Costa Pinto, ressalta a complexidade e heterogeneidade da

52 "Romancista e autor de contos. Publicou de1963 a 1981, com crescente sucesso: Os Prisioneiros, A Coleira do Cão, Lucia McCartney, O Homem de Fevereiro ou Março (Antologia), O 
prosa brasileira nas últimas décadas, situando-a a partir dos anos 1950/1960 pelo seguinte critério:

L'idée d'émancipation culturelle qui fait que le Brésil, premièrement cesse d'être un simple récepteur des tendances européennes et norsaméricaines, et, deuxièmement, entend rompre avec les déterminismes du discours sur l'identité nationale. (Pinto, 2005, p.30) ${ }^{53}$

Segundo Costa Pinto (2005, p.31), o debate sobre a nacionalidade como elemento marcante da cultura brasileira transforma-se com o processo de modernização e urbanização, "sem o qual é impossível de se compreender a literatura contemporânea".

Rubem Fonseca é citado quando o panorama atinge a década de 1960:

Alors que le discours de la nationalité survit dans la réthorique dês mouvements populaires, et après le coup d'État de 1964, dans les campagnes civiques militaires, la décennie 1960 voit surgir d'une part une littérature d'introspection psychologique, d'exploration de l'individu atomisé et encapsulé dans une intériorité discontinue (les romans de Lúcio Cardoso et Clarice Lispector), et d'uatre part une prose dominée par le thème de la marginalité et de la violence urbaines (dans les nouvelles de João Antonio et Rubem Fonseca ou dans l'univers en miniature de Dalton Trevisan). (ibidem, p.33) ${ }^{54}$

Fenômeno recente e irreversível, a urbanização do imaginário da literatura brasileira convive com um regionalismo que aparece "sob o signo de um exotismo de exportação" nos últimos romances de Jorge Amado ou como regionalismo antinaturalista na obra de João Ubaldo Ribeiro. Para Costa Pinto, a diversidade das correntes narrativas corresponde à idéia que cada autor faz do homem de hoje, mas, sobretudo, de sua experiência nas cidades:

Caso Morel e Feliz Ano Novo. Apresentamos aqui a tradução de um conto muito representativo de uma escrita da 'desintegração social' e da vida nas grandes cidades brasileiras."

53 "A idéia de emancipação cultural que faz com que o Brasil, em primeiro lugar, pare de ser um simples receptor de tendências européias e norte-americanas e, em segundo, pretenda romper com os determinismos do discurso sobre a identidade nacional."

54 "Enquanto o discurso da nacionalidade sobrevive na retórica dos movimentos populares e, após o Golpe de Estado de 1964, nas campanhas cívicas militares, a década de 1960 vê surgir, por um lado, uma literatura de introspecção psicológica, de exploração do indivíduo atomizado e encapsulado em uma interioridade descontinua (os romances de Lúcio Cardoso e Clarice 
En fin de compte, l'idée d'une pluralité de destins et d'une liberté individulelle, incarnée par des personnages différents à travers différents modes d'expression, est une construction culturelle qui naît avec la ville et se matérialise en formes littéraires qui transitent entre le registre de l'essai, le réalisme, le métaphysique, l'eschatologiuqe, le fantastique et le satirique.

Gardant à l'esprit cette idée que la prose brésilienne des dernières décennies se développe comme une prolifération de microcosmes urbains, il est possible de distinguer, à des fins purement didactiques, deux grandes tendances: 1. une fiction de type subjectif, centrée sur le paysage intérieur des personnages et sur les jeux d'identité ; 2. une prose d'origine néoréaliste où les sujets en action sont toujours confrontés à des forces objectives qui les submergent. (ibidem, p.35) ${ }^{55}$

Costa Pinto relaciona os representantes da primeira corrente, mais interior, e seus desdobramentos e intersecções com narrativas de teor político e de DECHIRURE social, citando de Lúcio Cardoso e Clarice Lispector a Zulmira Ribeiro Tavares, Modesto Carone e Rubens Figueiredo, passando por Lygia Fagundes Telles, Hilda Hilst, Bernardo Carvalho e Chico Buarque. Em seguida, repertoria a corrente do grupo de escritores que, recuperando o senso crítico do realismo regionalista, opta por uma perspectiva antiutópica num ambiente urbano:

Le caractère fragmentaire des récits traduit l'impossibilité de l'émancipation politique et une sorte de dilacération du sujet imposée par la nouvelle réalité. Ces traits s'esquissaient déjà dans l'oeuvre de conteurs comme Joâo Antonio e Rubem Fonseca qui ont introduit dans la littérature brésilienne une nouvelle faune de personnages : voyous, prostituées, trafiquants, bandits édentés, flics, enquêteurs, riches pervertis, mendiants, enfin, pauvres diables de toute sorte, "petites créatures », pour reprendre le titre d'un des derniers livres de Fonseca, vagabonds à la périphérie du capitalisme. (ibidem, p.39) ${ }^{56}$

Lispector) e, de outro, uma prosa dominada pelo tema da marginalidade e da violência urbanas (nos contos de João Antônio e Rubem Fonseca ou no universo em miniatura de Dalton Trevisan)."

55 "No final das contas, a idéia de uma pluralidade de destinos e de uma liberdade individual, encarnada por personagens diferentes através de diferentes modos de expressão, é uma construção cultural que nasce com a cidade e se materializa em formas literárias que transitam entre o registro de ensaio, o realismo, a metafísica, a escatologia, o fantástico e o satírico.

Mantendo em mente esta idéia de que a prosa brasileira das últimas décadas se desenvolve como uma proliferação de microcosmos urbanos, é possível distinguir, para fins puramente didáticos, duas grandes tendências: 1. uma ficção do tipo subjetivo, centrada na paisagem interior das personagens e nos jogos de identidade; 2 . uma prosa de origem neo-realista em que os temas em ação são sempre confrontados a forças objetivas que os submergem."

${ }_{56}$ "O caráter fragmentário das narrativas traduz a impossibilidade da emancipação política e uma espécie de dilaceração do tema imposto pela nova realidade. Esses traços se esboçam já na obra de contistas como João Antônio e Rubem Fonseca, que introduziram na literatura brasileira uma nova fauna de personagens: ladrões, prostitutas, traficantes, bandidos desdentados, tiras, investigadores, ricos pervertidos, mendigos, enfim, pobres diabos de toda espécie, 'criaturinhas', para retomar o título de um dos últimos livros de Fonseca, errantes na periferia do capitalismo." 
Costa Pinto afirma que a semente plantada por João Antonio e Rubem Fonseca nos anos 1960 deu origem, no auge da ditadura, ao "boom" do conto brasileiro dos anos 1970 e estão presentes na obra de Sérgio Sant'Anna, Ignácio de Loyola Brandão e Ivan Ângelo:

La dénonciation sociale, cependant, ne prend pás la forme d'une littérature engagée ou liée à des messages idéologiques. En partie à cause de la censure, qui exigeait des recours stylistiques antinaturalistes pour tromper la vigilance officielle, en partie pour démonter les mécanismes aliénants dissiminés par la culture de masse, ces récits recourent à des jeux métalinguistiques et s'approprient des instruments de l'industrie culturelle dans des fictions allégoriques. (ibidem, p.39-40) ${ }^{57}$

Como conseqüência dessa literatura da violência, surge após a abertura política, segundo Costa Pinto, a "Geração 90" de escritores, representados por Marçal Aquino e Ronaldo Bressane, entre outros, que em sua heterogeneidade representam as vozes do realismo urbano, ao qual se contrapõe uma outra corrente, a do "realismo suburbano", na pluma de Luiz Ruffato, Fernando Bonassi e Bruno Zeni.

Costa Pinto cita, igualmente, outras vertentes e tendências do caleidoscópio literário contemporâneo brasileiro, dos romances "étnicos" aos históricos, documentais, até chegar a um fenômeno recente: os romances de entretenimento de qualidade, freqüentemente do gênero policial, como os de Patrícia Melo e Luiz Alfredo Garcia-Roza; humorísticos ou tramas lúdicas com enigmas filosóficos no estilo de Umberto Eco.

Antes de encerrar exaltando Paulo Lins e Ferréz, como o mais novo fenômeno literário brasileiro, pois são originários das favelas, Costa Pinto cita dois autores considerados best-sellers no exterior: Paulo Coelho e Luís Fernando Veríssimo.

\footnotetext{
57 "A denúncia social, entretanto, não toma a forma de uma literatura engajada ou ligada a mensagens ideológicas. Em parte, por causa da censura, que exigia recursos estilísticos antinaturalistas para enganar a vigilância oficial, em parte para desmontar os mecanismos alienantes disseminados pela cultura de massa, essas narrativas recorrem a jogos metalingüísticos e se apropriam dos instrumentos da indústria cultural em ficções alegóricas."
} 
Vale aqui ressaltar o sucesso obtido por Patrícia Melo e Luiz Alfredo GarciaRoza, citados, em solo francês. Ambos publicados pela Actes Sud, uma editora que tem orgulho em proclamar que edita apenas o que the agrada no cenário conflituoso da atual edição francesa, não só mantêm-se conhecidos e lidos, como abrem caminho para outros autores do gênero, como Tony Bellotto, que verá em breve seu livro Bellini e o demônio traduzido para a língua francesa pela Actes Sud. Desses três autores, Patrícia Melo é reconhecidamente discípula de Fonseca. A editora Actes Sud conta lançar uma coleção específica do gênero romance policial, na qual figuraram apenas Roza e Bellotto. A obra de Patrícia Melo é considerada de forma especial pela editora e será publicada à parte. ${ }^{58}$

Nova ênfase será dada ao gênero em questão no artigo de Marcelo Coelho (2005) "Les bons et les méchants" que sucede o artigo de Manuel da Costa Pinto.

O artigo de Coelho começa com uma interrogação de José Paulo Paes sobre a quase inexistência de uma literatura brasileira de entretenimento de qualidade. Coelho ressalta que, paralelamente ao questionamento de José Paulo Paes em 1989, "le roman du type policier cessait d'être une littérature de second plan pour occuper un rôle central dans la production littéraire brésilienne" (ibidem). ${ }^{59}$ Coelho (2005, p.45-7) afirma que essa moda começou com a abertura do regime militar por volta de 1985, mas passa então a fazer um histórico do gênero a partir dos anos 1960 citando João Antonio e Rubem Fonseca, escritores que produziram em pleno regime militar.

Coelho passa rapidamente por João Antonio para dedicar a maior parte de seu artigo ao percurso de Rubem Fonseca a partir de Feliz ano novo. Passa então a elencar a nova geração de escritores, destacando Patrícia Melo dentre as discípulas de Fonseca, assim como Marcelino Freire, Edyr Augusto, Ademir Assunção, Fernando Bonassi e Marçal Aquino. Dá especial atenção também a Paulo Lins, Ferréz, Luiz Alfredo Garcia-Roza, entre outros, mantendo sempre Rubem Fonseca como fio condutor de seu artigo.

\footnotetext{
${ }^{58}$ Depoimento fornecido por Alzira Martins, Secretária Geral responsável pela América do Sul e Diretora de Coleção na Editora Actes Sud, em 9 de março de 2006, na ocasião da Bienal do Livro de São Paulo.
} 
O terceiro artigo "La dialectique de la 'marginalité' et la violence dans la culture brésilienne contemporaine", de João Cezar de Castro Rocha (2005), enfoca mais precisamente, de um ponto de vista sociológico, o cinema nacional a partir da versão cinematográfica do livro de Paulo Lins Cidade de Deus, para dissertar sobre a dialética da malandragem. Menção será feita a Rubem Fonseca quando Rocha compara a violência da personagem Zé Pequeno à raiva da personagem de "O cobrador". Segundo Rocha (2005, p.69), trata-se da autêntica prefiguração da atual dialética da marginalidade".

Já o artigo de Eliane Robert Moraes (2005, p.112), "Topographie du risque", consagrado ao erotismo na literatura brasileira, mencionará Fonseca apenas no final como um dos escritores brasileiros "institucionalizados", que começam a descobrir a veia do erotismo.

O módulo seguinte, "Portraits", traz ensaios dedicados a autores específicos, juntamente com traduções de seus textos. São sete autores: Ferreira Gullar (apresentado por Alcides Villaça), Hilda Hilst (apresentada por Alcir Pécora), Francisco Alvim (por Viviane Bosi), Rubem Fonseca (por Florent Kohler), Dalton Trevisan (por Manuel da Costa Pinto), João Ubaldo Ribeiro (por Rita Olivieri-Godet) e Haroldo de Campos (por Leyla Perrone-Moisés). O tradutor de "Déjeuner à la montagne un dimanche de carnaval", Florent Kohler (2005, p.1848), assina igualmente o ensaio "Littérature et bricolage", consagrado a Rubem Fonseca. Esse é o único caso nesse bloco em que o autor do ensaio assina igualmente a tradução.

Esse antropólogo inicia seu artigo indo diretamente a um ponto que muitas vezes incomodou a crítica brasileira, dividindo-a. Kohler afirma que há nos escritos de Rubem Fonseca material para satisfazer diversos tipos de leitores.

Quiconque apprécie les clins d'oeil à l'amateur éclairé, trouvera dans ses subtiles constructions romanesques, ses jeux de narration, lavariété de ses contes et nouvelles, la preuve qu'il existe au Brésil des écrivains capables de s'approprier et de renouveler, en l'acclimatant, un genre littéraire, en l'espèce le roman noir. Mais le lecteur du dimanche, le citoyen lambda « qui ne lit qu'un livre par mois (ou moins), aura également lieu d'être satisfait. Difficile en effet

\footnotetext{
59 "o romance do tipo policial parava de ser relegado à literatura de segundo plano para ocupar um papel central na produção literária brasileira."
} 
d'entamer un roman de Rubem Fonseca sans être pris du désir irrépressible de le terminer. (Kohler, 2005, p.184) ${ }^{60}$

As quase quatro páginas de Kohler, vestíbulo de sua tradução, apresentam Rubem Fonseca e sua obra. São citados inicialmente O cobrador, Os prisioneiros, Feliz ano novo, Bufo \& Spallanzani. Nenhuma menção é feita a Agosto, que parece ter sido um dos os romances mais lidos pelo público francês. Há referência a Vastas emoções e pensamentos imperfeitos e $O$ selvagem da ópera para realçar o comentário que "os imbróglios romanescos de Fonseca [...] remetem mais à ficção cinematográfica que propriamente literária", podendo decepcionar os leitores (ibidem, p.187). O romance $A$ grande arte é citado para concluir o artigo.

É preciso salientar que a consagração de Rubem Fonseca nessas três edições é, na sua maioria, de responsabilidade de articulistas brasileiros, ainda que com o aval de organizadores franceses. Portanto, a maior parte dos artigos veiculam uma visão da literatura brasileira dos próprios brasileiros.

Vinte e três anos separam as duas publicações mais recentes da Revue Europe. É possível verificar, por meio da análise comparativa, as diferentes intenções dos organizadores. Vale primeiramente salientar que ambas trazem um panorama adequado da literatura brasileira. Alguns detalhes nos fornecem, porém, elementos de análise contrastiva. Compreende-se a homenagem a Jorge Amado no cinqüentenário de sua vida literária. O conjunto da introdução "Une littérature sous les tropiques" e o texto do autor baiano, abrindo a edição, são característicos de uma visão exótica da literatura brasileira que, todavia, não se concebe como tal:

Sans doute quelques classiques brésiliens de la modernité ne sont-ils pas entièrement inconnus en France, mais ils servent fréquemment d'alibi à notre ignorance. Carlos Drummond de Andrade pour la poésie, plus récemment Clarice Lispector pour le récit au féminin, ou quelques rares auteurs aperçus au hasard des exils et des traductions impromptues, ne semblent être admis dans nos bibliothèques qu'en tant qu'exceptions venant

\footnotetext{
60 "Quem quer que aprecie as piscadelas ao amador esclarecido, encontrará em suas sutis construções romanescas, seus jogos de narração, a variedade de seus contos e novelas, a prova de que existe no Brasil escritores capazes de se apropriar e de renovar, aclimatando-o, um gênero literário, no caso, o romance noir. Mas o leitor de domingo, o cidadão comum, "que lê apenas um livro por mês (no máximo), terá também a oportunidade de ser satisfeito. Difícil, de fato, iniciar um romance de Rubem Fonseca sem ser tomado pelo desejo irreprimível de terminá-lo."
} 
peupler un désert et nous confirmer dans l'illusion que, s'il existe du moins quelques tentatives louables de création au Brésil, celles-ci ne sauraient passer pour constitutives d'une littérature digne de ce nom. Après tout, ainsi qu'laffirmait tout récemment encore un philosophe français - dont les opinions ne sont pas connues pour être particulièrement de droite - : "S'ils avaient un Dostoïevski, cela se saurait ! »; le « ils », global et méprisant, désignant sans appel l'ensemble des écrivains du Tiers Monde!

II nous paraît justement très urgent de savoir enfin qu'existe, en dehors de nous et quelques fois malgré nous, une véritable littérature "sous les tropiques » parfois et toujours quelque peu parfumée de cannelle, n'en possède pas moins une force généralisante l'égalant aux littératures de l'Europe ou de l'Amérique du Nord. (Bourjea, 1982. p.4) ${ }^{61}$

Jorge Amado foi o autor brasileiro mais traduzido para a língua francesa antes dos recentes fenômenos Paulo Coelho e Patrícia Melo. Um número especial da Revue Europe foi consagrado a Jorge Amado, em 1989 (724-725, agostosetembro 1989). Vale também salientar que uma antologia poética de literatura brasileira apareceu no número 827, de março de 1998 dessa mesma publicação.

61 “Certamente alguns clássicos brasileiros da modernidade não são inteiramente desconhecidos na França, mas servem com freqüência de álibi para nossa ignorância. Carlos Drummond de Andrade em relação à poesia, mais recentemente Clarice Lispector em relação à narrativa no feminino, ou alguns raros autores vislumbrados ao acaso dos exílios e das traduções circunstanciais, só parecem ser admitidos nas bibliotecas francesas como exceções, que vêm povoar um deserto e nos confirmar na ilusão de que, se existem pelo menos algumas tentativas louváveis de criação no Brasil, elas não poderiam passar por constitutivas de uma literatura digna desse nome. No final das contas, assim como bem recentemente afirmava ainda um filósofo francês - cujas opiniões não são conhecidas por ser especialmente de direita -: "Se eles tivessem um Dostoiévski, todos saberiam"; o "eles", geral e de desprezo, designando irremediavelmente o total dos escritores do Terceiro Mundo!"

Parece-nos exatamente muito urgente saber finalmente que existe, além de nós e, algumas vezes, apesar de nós, uma verdadeira literatura 'abaixo do Equador', às vezes e sempre um pouco perfumada de canela, que não deixa de possuir uma força generalizante igualando-a às literaturas da Europa ou da América do Norte." 


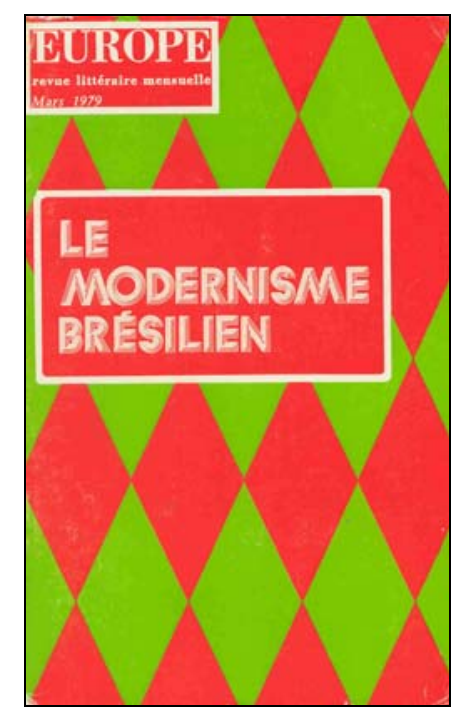

1979

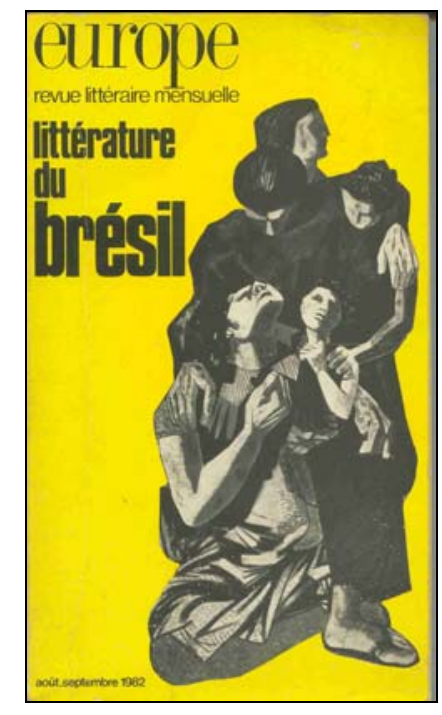

1982

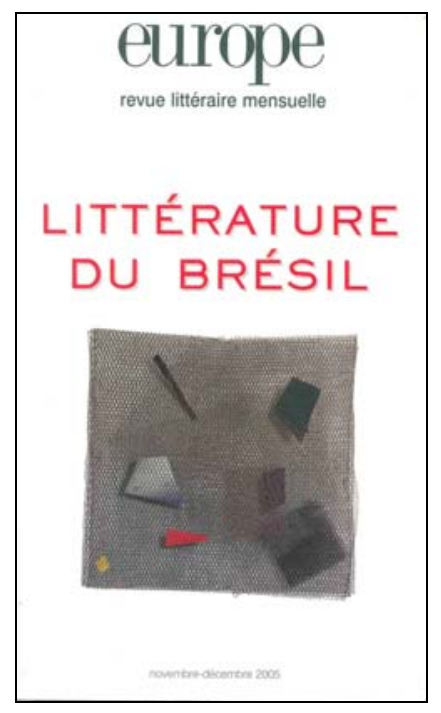

2005

A análise das capas e contracapas dessas três publicações fornece uma idéia da progressão da imagem do Brasil na França por meio de sua literatura. A evolução das opções gráficas parece corresponder a um processo que caminha para a harmonia de capa e contracapa da publicação. A capa arlequinal da edição de 1979 corresponde ao espírito das vanguardas modernistas brasileiras. A contracapa dessa edição (abaixo) não tem nenhuma ligação com o Brasil. Tratase de uma publicidade do livro Proust: le temps du désir. Na edição de 1982, o recorte da obra de Portinari "Sacrifício de Tiradentes" parece fazer a ponte entre as vanguardas do início do século XX e o escritor Jorge Amado, na contracapa, representante máximo da literatura brasileira no exterior. Nessa edição já surge consonância, pelo menos no que se refere à temática de literatura brasileira, entre capa e contracapa. A edição mais recente traz na capa obra do artista plástico brasileiro Arthur Luiz Piza, e a contracapa apresenta resumo do dossiê sobre a literatura brasileira contemporânea com a lista dos autores que participaram da publicação. 


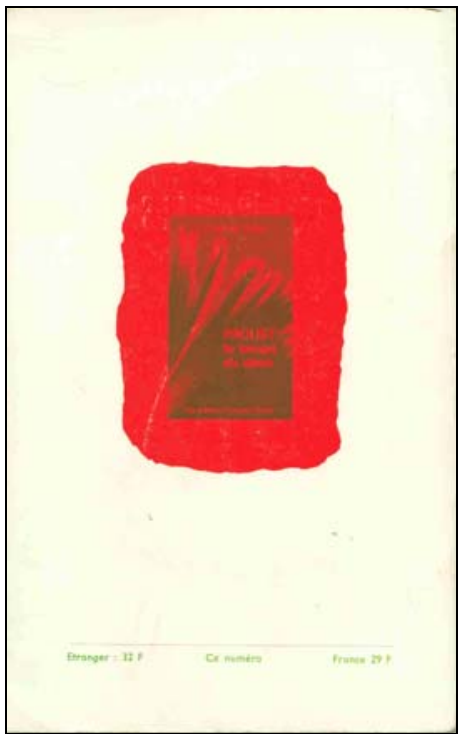

1979

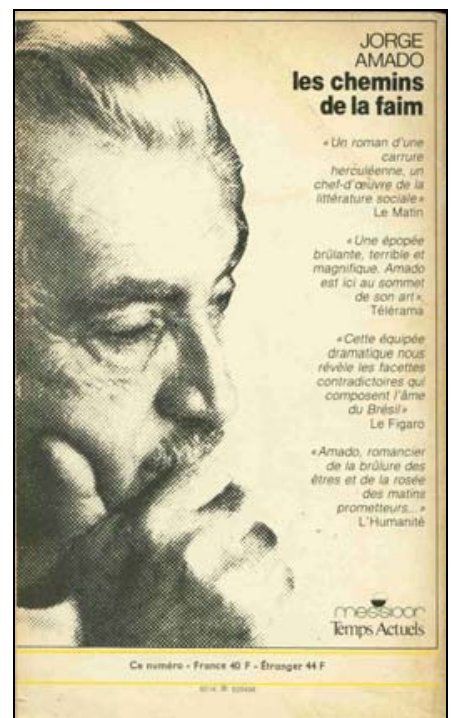

1982

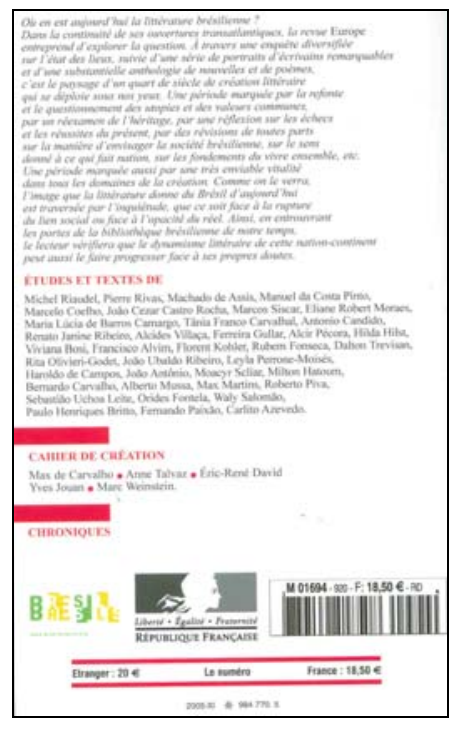

2005

O exame do material visual paratextual e dos textos que o acompanham são reveladores da imagem que os organizadores e editores pretendem passar da cultura brasileira. O próximo capítulo apresenta reflexões acerca desse material em algumas antologias, nas quais figuram contos de Rubem Fonseca, e no conjunto de seus romances traduzidos na França. 


\section{II \\ Intermediação editorial}

Todo texto que se agrega a um texto base é, para Gérard Genette (1987), paratexto. Nesse sentido, o objeto livro, na prateleira de uma livraria, oferece ao leitor potencial uma série de informações que o conduzirão, ou não, ao cerne do objeto, o texto do autor. Essas informações paratextuais são o "vestíbulo" do texto autoral e são dirigidos especificamente a uma comunidade com interesses comuns, o público-alvo. Dentre as inúmeras categorias paratextuais listadas por Genette (epígrafes, instâncias prefaciais e posfaciais, notas internas ao texto autoral, epitextos variados, fortuna crítica etc.), interessa neste capítulo, em princípio descritivo, a categoria que contempla o que visualmente se apresenta ao leitor: a apresentação externa do livro, sua capa, como nela figuram o nome do autor e outros elementos a ele relacionados, o título da obra, a indicação de 
gênero, a indicação da origem da obra e menção ao tradutor, eventualmente a indicação catalográfica, o crédito de capa, o tipo de edição, o preço. Todas as informações contidas na capa, contracapa, orelha ou terceira página, material sob responsabilidade direta do editor (mas não exclusiva), ou da comissão editorial em geral são denominadas por Genette como peritexto editorial. ${ }^{62}$

Cabe aqui avaliar a recepção da obra de Rubem Fonseca com base no peritexto editorial a fim de se examinar a proposta editorial que deu surgimento ao objeto livro, apresentado ao público leitor francês. A análise inicia-se pelo exame do material paratextual e busca verificar de que forma as edições francesas lançaram esse produto, e em que medida esse material enfatiza ou não uma imagem clichê do Brasil, construída a partir de um exotismo inicialmente caricatural de elementos nacionais como a música, o futebol, o biótipo e a mentalidade brasileiras e, mais recentemente, social, por meio da pobreza e da violência urbana; ou ainda, valoriza ou despreza certos aspectos biográficos, críticos ou literários do autor brasileiro. Dessa forma, poder-se-á verificar de que maneira os paratextos são reveladores da intencionalidade do editor e podem ilustrar um projeto editorial ao se eleger traduzir e publicar determinado autor estrangeiro.

\section{Capas, contracapas e entornos de antologias}

A título de amostragem e complementando as descrições e análises iniciais consagradas à Revue Europe no I Capítulo, inicia-se aqui a apreciação do material a que se teve acesso no que se refere ao paratexto das antologias.

\footnotetext{
${ }^{62}$ Embora não tenha sido a intenção primeira, quando possível, foram examinadas igualmente algumas instâncias prefaciais a que se teve acesso.
} 


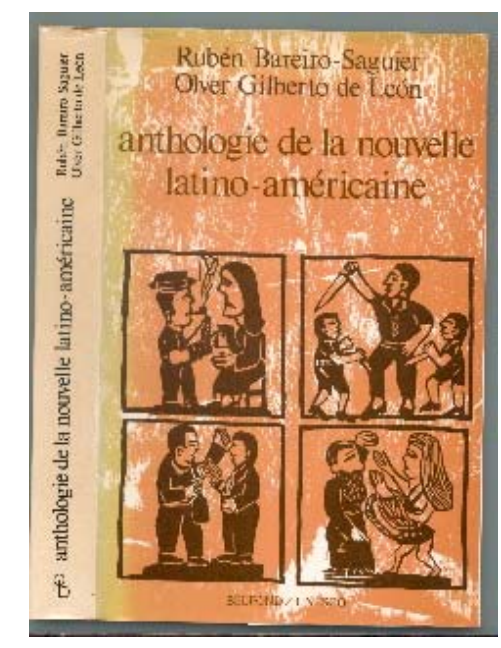

A primeira capa concerne a Anthologie de la nouvelle latino-américaine, ${ }^{63}$ na qual figura o conto "Gazelle" ("Gazela"), de 1991. Sobre um fundo ocrealaranjado, figuram os nomes dos organizadores Rubén Bareiro Saguier e Olver Gilberto de Leon; em seguida, o título da antologia e quatro ilustrações em cordel, aparentemente independentes umas das outras. Na primeira (parte superior à esquerda), um homem e uma mulher conversam, ele fuma cachimbo e ambos parecem beber algo. Na segunda (parte superior à direita), três indivíduos, cada um com uma faca, parecem brigar entre si. Na terceira gravura (parte inferior à esquerda), dois homens parecem confraternizar-se bebendo. E na última (parte inferior à direita), uma mulher tenta pegar um objeto da mão de uma outra mulher ou um padre.... não se sabe ao certo. Independentes ou não, pois podem estar contando uma história. Por fim, figura o nome da editora/instituição patrocinadora: Belfond/Unesco. Essa publicação encontra-se esgotada.

A capa da antologia Ménaces: Anthologie de la nouvelle noire et policière latino-américaine, de 1993, apresenta o nome do organizador, Olver Gilberto de Leon, o título em grandes letras vermelhas, seguido do subtítulo, uma ilustração e o nome da editora: L'Atalante. A ilustração de Xavier De Sierra, jovem artista uruguaio residente na França (indicação na orelha da contracapa), é bastante sugestiva: um homem sentado perto de uma janela, olha por essa janela, sem

\footnotetext{
${ }^{63}$ Não se teve acesso direto à publicação Anthologie de la nouvelle latino-américaine, de 1991. Também não se teve acesso ao texto de apresentação da contracapa.
} 
talvez perceber elementos inquietadores no interior da peça na qual se encontra: ao fundo, uma janela de treliça deixa entrar parcialmente a luz do exterior, no chão, um vulto de mulher em vermelho sugere a sombra de mais alguém presente no cômodo, e a parede atrás do homem apresenta um ameaçador efeito de redemoinho. Eventuais tons pastéis contrastam com o negro e o vermelho preponderantes.

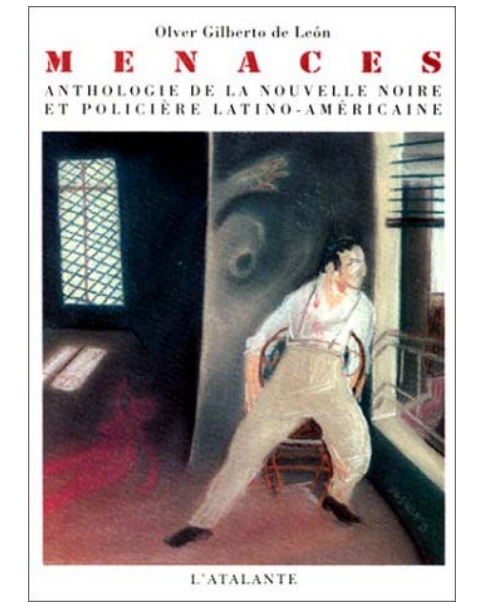

A ilustração corresponde ao conteúdo do texto da contracapa:

"Quand il est sorti du Paris et que la nuit lui a cinglé les joues d'un coup de fouet glacial, il a su que le type l'attendrait près de la bouche du métro... » Sujet même de la nouvelle ou présence diffuse entre les lignes, la menace est là, émanation d'un pouvoir dénaturé, d'organisations occultes, ou expression $d u$ «double destructeur » tapi en chacun de nous. Cette présence insistante n'est bien sûr pas étrangère à l'histoire de l'Amérique latine. Une histoire à l'image de la violence qui traverse ces nouvelles: explosive, baroque ou contenue, elle se manifeste sous des jours aussi variés que les auteurs réunis dans ce recueil. De Borges à Juan Martini et Taibo II en passant par Rubem Fonseca, tous démontrent, au-delà des classifications et des genres, la vivacité de la littérature latino-américaine où la noirceur prend des accents profondément originaux et insolites. Par la diversité de ses choix, par le nombre de textes inédits, par son ouverture dans l'espace et dans le temps, cette anthologie ouvre à l'amateur de textes noirs comme au curieux un panorama des plus passionnants. ${ }^{64}$

\footnotetext{
64 "'Quando ele saiu de Paris, e que a noite açoitou suas faces com uma chicotada glacial, ele soube que o cara o esperaria próximo à entrada do metrô...' Tema de fato do conto ou presença difusa entre as linhas, a ameaça está ali, emanação de um poder desnaturado, de organizações ocultas, ou expressão do 'duplo destruidor' escondido em cada um de nós. Esta presença insistente, certamente não é estranha à história da América Latina. Uma história espelhando a violência que atravessa estes contos: explosiva, barroca ou contida, ela se manifesta sob aparências tão variadas quanto os autores reunidos nesta coletânea. De Borges a Juan Martini e Taibo II, passando por Rubem Fonseca, todos demonstram, para além das classificações e dos gêneros, a vivacidade da literatura latino-americana, onde a perfídia toma aspectos profundamente originais e insólitos. Pela diversidade de suas escolhas, pelo número de textos inéditos, por sua
} 
Segundo o texto, a "ameaça" é protagonista das 35 histórias reunidas no volume, que pode contemplar tanto os amadores de literatura "noire" como os curiosos de literatura latino-americana. Os autores citados no texto correspondem a três nacionalidades: os argentinos Borges e Juan Martini, o mexicano de origem espanhola Paco Ignacio Taibo II, e o brasileiro Rubem Fonseca. Vale salientar que, dentre os autores selecionados, cinco são brasileiros: Rubem Fonseca, Caio Fernando Abreu, Dalton Trevisan, Carlos Drummond de Andrade e Josué Guimarães. É interessante observar que, dentre os cinco brasileiros, o nome de Rubem Fonseca tenha sido escolhido para figurar no texto da contracapa, em evidência.

Consta em comentário pesquisado no site da Amazon.fr haver no final da publicação uma breve biografia e sugestões de bibliografia complementar. Essa publicação teve diversas reedições $(1995,1998)$ e está atualmente esgotada.

A antologia Contes de Noël brésiliens (Contos para um natal brasileiro) retoma dezesseis contos publicados na antologia brasileira em 1996 pela editora Relume-Dumará. Dos contos selecionados, todos se referem diretamente às festas natalinas ou sugerem, como o de Antonio Torres, "Segundo Nego Roseno", um período de festas com missas. O conto de Rubem Fonseca é o único a não se relacionar diretamente com o tema.

Considerou-se apropriado adiantar aqui algumas reflexões a respeito do conto em questão com base no material textual, a fim de elucidar elemento tão obscuro, pois após a descoberta da edição brasileira a questão tornou-se premente: Por que os brasileiros selecionaram exatamente esse conto para uma coletânea de contos de natal, se seu tema é tão mais universal que a festa natalina?

Em "O outro", o narrador, um executivo, é freqüentemente interpelado por um pedinte na rua. Torna-se uma obsessão para o protagonista fugir ao assédio da pessoa que mendiga. Por um certo tempo, obtém sucesso em sua empreitada,

abertura no espaço e no tempo, esta antologia desvela ao amador de textos noirs, como aos curiosos, um panorama dos mais apaixonantes." 
mas em um derradeiro encontro em que o mendigo o segue até sua casa, o narrador pede que espere por ele na entrada e, ao regressar, atira no menino. $O$ conto encerra-se da seguinte forma:

Fechei a porta, fui ao meu quarto. Voltei, abri a porta e ele ao me ver disse "não faça isso, doutor, só tenho o senhor no mundo". Não acabou de falar ou se falou eu não ouvi, com o barulho do tiro. Ele caiu no chão, então vi que era um menino franzino, de espinhas no rosto e de uma palidez tão grande que nem mesmo o sangue, que foi cobrindo a sua face, conseguia esconder.

Ao se comparar as capas das edições brasileira e francesa, à primeira vista observam-se a simplicidade da primeira e o refinamento da segunda. Essa apresenta uma sobrecapa azul-esverdeado-escura, com ilustração colorida que envolve a capa dura branca, sem ilustração, com letras nos tons azul, claro e escuro. Nota-se na capa da edição brasileira, de autoria de Victor Burton, uma maior generalização do tema: um sol, um anjo, flores. Consta igualmente o nome de todos os autores, por ordem alfabética (Antonio Callado, Antônio Torres, Carlos Drummond de Andrade, Carlos Nascimento e Silva, Carlos Süssekind, Dalton Trevisan, Eric Nepomucemo, João Ubaldo Ribeiro, Luis Fernando Veríssimo, Lygia Fagundes Telles, Machado de Assis, Moacyr Scliar, Naum Alves de Souza, Nélida Piñon, Paulo Coelho e Rubem Fonseca), assim como o nome das editoras Relume-Dumarállbase. Além do título, somente a presença da iconografia do anjo remete o leitor ao período natalino. A colorida ilustração de Luiz Carlos Figueredo na parte superior da sobrecapa da edição francesa traz o Menino Jesus dentro de um mapa do Brasil descendo do céu e sendo recebido por Maria e José, os reis magos e alguns animais, pássaros brancos aos pares e cabeças de equinos, que estão sorrindo. Figura igualmente o nome da editora "Albin Michel", em rosa-claro, abaixo da ilustração e do título que está centralizado, escrito com as cores dourada, vermelha e branca, em alusão ao Natal.

O texto da contracapa francesa reforça esse descompasso, no que se refere ao conto fonsequiano. De imediato, após a retomada do título, é afirmado em um texto de apresentação do livro que "Les plus grands auteurs brésiliens contemporains se sont donné rendez-vous pour célébrer Noël". No segundo 
período do texto, o natal brasileiro é inevitavelmente relacionado ao "rythme des airs exotiques". Para completar o quadro, três autores merecem destaque: o primeiro é Paulo Coelho, cujo texto recebe o adjetivo de "merveilleusement simple". Há ainda a menção a um dos best-sellers do autor, L'alchimiste (O alquimista). O segundo autor citado é Carlos Drummond de Andrade, atentandose para o teor sarcástico de seu conto. Finalmente, menciona-se o conto sensível e inquietante de Machado de Assis. O final do texto convida o leitor, amante de literatura, a ler os contos e a "rêver d'un Noël sous d'autres cieux", festejando a data de uma maneira diferente, "entre samba et messe de minuit". Eis o texto da contracapa em sua íntegra:

Les plus grands auteurs brésiliens contemporains se sont donné rendez-vous pour célébrer Noël. Chacun à sa manière nous offre un tableau saisissant de cette fête universelle sous le soleil de l'autre hémisphère où, comme ailleurs, se retrouvent la ferveur, la prière, l'espoir, mais aussi la fête et la joie exprimées au rythme des airs exotiques.

Merveilleusement simple et sublime comme le texte de Paulo Coelho, l'auteur de L'Alchimiste, - la prière inattendue qu'un gamin adresse à Dieu- ; sarcastique comme la nouvelle de Carlos Drummond de Andrade avec son voleur déguisé en Père Noël; sensible comme le troublant dialogue qu'échangent une femme et un adolescent mis en scène par Machado de Assis : les contes singuliers de ce recueil réservent quelques belles surprises aux amateurs de littérature ainsi qu'à ceux qui veulent rêver d'un Noël sous d'autres cieux, et le fêter autrement, entre samba et messe de minuit. ${ }^{65}$

65 "Os maiores autores brasileiros contemporâneos se reuniram para festejar o Natal. Cada um à sua maneira nos oferece um quadro impressionante desta festa universal onde, como em outros lugares, encontra-se o fervor, a prece, a esperança, mas também a festa e a alegria expressas no ritmo das melodias exóticas.

Maravilhosamente simples e sublime como o texto de Paulo Coelho, o autor de O Alquimista - a prece inesperada que um garoto dirige a Deus; sarcástica como o conto de Carlos Drummond de Andrade, com seu ladrão disfarçado de Papai Noël; sensível como o perturbador diálogo entre uma mulher e um adolescente criado por Machado de Assis: os contos singulares desta coletânea reservam belas surpresas aos amantes de literatura, assim como àqueles que querem sonhar com um Natal sob outros céus, e festejar de outra forma, entre samba e missa da meia noite." 

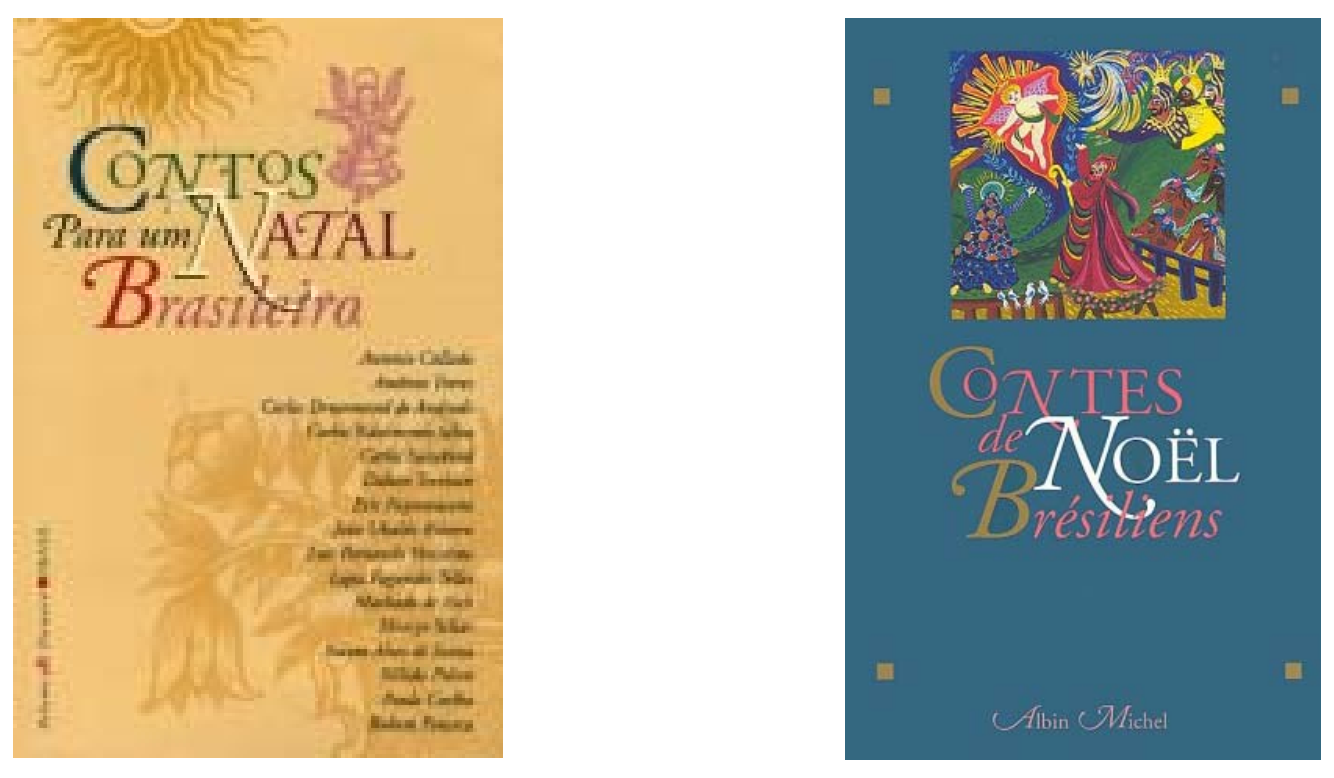

Embora a grafia do título na edição francesa siga o modelo da edição brasileira (diferentes tipos gráficos para cada letra), há um flagrante descompasso na sua tradução para a língua francesa pela mudança da preposição para/de e a atribuição do adjetivo "brasileiro". Em português, trata-se de contos PARA um natal brasileiro, enquanto em francês são contos $D E$ natal brasileiros. Na edição brasileira, sugere-se que os contos, tenham eles ou não o tema natalino, podem ser lidos na época do Natal, ou servirão de alguma forma ao Natal dos brasileiros. Já o título da edição francesa promete ao leitor contos brasileiros de Natal. O descompasso é maior quando se leva em consideração que o conto "O outro" de Rubem Fonseca não tem relação direta com o Natal, a não ser pela falta de solidariedade do narrador que, ao final, mata o pedinte que o incomoda.

O exame da contracapa brasileira esclarece quanto ao projeto editorial da publicação:

Há três anos, Betinho vem lutando por um Natal sem Fome. Agora, um elenco expressivo de autores nacionais se junta a ele na luta contra a fome e a miséria, no sonho de um Natal mais solidário.

Este livro apresenta, em diferentes estilos, em contos já conhecidos e outros inéditos, a solidariedade e a esperança, o Natal e os sentimentos que desperta. Desde o Natal singelo do casal Maria e José até o Natal de strippers de São Paulo.

É muito o que a cultura pode fazer pelo país e Contos Para um Natal Brasileiro é apenas uma pequena amostra do que pode resultar o encontro arte e solidariedade. 
Na versão francesa, a explicação consta da página 9:

Titre original:

CONTOS PARA UM NATAL BRASILEIRO

Les auteurs, publié par Relume Dumará, Rio de Janeiro

Voir sources page 175

Traduction française :

Editions Albin Michel S. A., 1997

22, rue Huyghens, 75014 Paris

ISBN 2-226-09512-8

As fontes, listadas à página 175, também não revelam o projeto social por trás da edição brasileira. Não há na edição francesa nenhuma instância prefacial ou posfacial que indique o objetivo da edição original. A edição brasileira apresenta, quanto a ela, mais dois paratextos. O primeiro consiste em uma apresentação do próprio Betinho:

Desde 93, a sociedade civil, mobilizada, vem lutando contra a indigência. Neste processo, já aglutinou cerca de 3 milhões de pessoas em comitês de Ação da Cidadania, em todo país. O brasileiro se indignou com a miséria disseminada em sua terra. Descobriu que a pobreza pode ter rosto muitas vezes, o de seu vizinho. E que bastava uma cesta de democracia para matar toda a fome de comida, justiça, trabalho, solidariedade.

Esta mobilização ganha força especial próximo ao 25 de dezembro. Quem consegue pensar em uma noite de Natal indigente, sem casa, sem comida? Assim nasceu, ou melhor, veio à tona, o sonho de um Natal sem Fome. Que, pelo menos uma vez ao ano, ninguém fique sem comida na noite de Natal. Com este projeto, mobilizam-se comitês em todo país, a fim de garantir mais justiça social. Que as crianças possam ter com o que brincar. Afinal, criança também tem fome de brinquedo.

Contos para um Natal brasileiro é contribuição dos autores para saciar a fome de nosso imaginário. O Brasil precisa construir o seu Natal. Em todos os sentidos. Precisa criar uma sociedade mais justa, fraterna, com igualdade de participação. Para isso, é preciso que ela exista antes dentro de cada cidadão e cidadã. O livro é uma possibilidade de mudança na cultura de cada leitor. Um país não muda pela sua economia, sua política e nem mesmo sua ciência; muda sim pela sua cultura.

Betinho 
O segundo paratexto encontra-se nas orelhas da edição brasileira:

Contos para um Natal brasileiro torna explícita uma comunhão praticada sempre, e que aqui, neste livro e neste momento, manifesta-se na sua expressão mais aguda. Arte e solidariedade, mesmo quando praticadas isoladamente, são a mesma coisa: um gesto fecundo de amor à vida. Esta seleção de craques da literatura brasileira, convocada pelo Betinho, entra em campo para participar, com sua arte, da campanha Natal sem Fome.

Tendo sido esta a primeira razão para a existência do livro, fica agora o leitor contemplado com um encontro que, do ponto de vista literário, traz algumas surpresas e muitos efeitos. Quem diria que existe entre nós uma produção de contos ancorados no ambiente natalino e nos sentimentos e expectativas - mesmo sendo os mais diversos e até mesmo contraditórios que este momento desperta? Na tradição contemporânea da nossa literatura, tudo parece ter começado com o conto Missa do Galo, do mestre Machado de Assis. Nada de celebração explícita ao Natal, mas o ritual da festa e os sentimentos que ela evoca como pano de fundo. É na espera da hora da missa que alguma coisa, tão permanente e também tão fulgaz, se insinua.

De passo com a celebração com o nascimento do Menino Jesus, Conceição celebra a seu modo aquilo que seria apenas uma possibilidade, deixando para sempre impressionado o jovem Nogueira de 17 anos.

Propositadamente, incluiu-se nessa coletânea alguns contos em que não há nenhuma referência ao Natal, como O outro, de Rubem Fonseca, ou Segundo Nego de Roseno, de Antônio Torres, mas mesmo assim a evocação da solidariedade e da esperança surgem como temática principal. No caso do conto de Rubem Fonseca, aquele empresário moderno, acuado e solitário bem atualiza - sinal da globalização? - o avarento Scrooge, do Christimas Carol, de Charles Dickens.

Reunindo contos já conhecidos e outros inéditos ou até então somente publicados em jornais e revistas, estes textos assumem aqui uma nova vida e adquirem um significado muito especial: demonstram o vigor do conto brasileiro, mesmo quando reunidos em torno da temática do Natal.

Assim, a presença do conto justifica-se plenamente na edição brasileira, porém permanece o estranhamento na edição francesa que não apresenta nenhuma explicação. A edição francesa é facilmente encontrada nas livrarias e custa aproximadamente 20 euros.

Considerado "Livro de bolso" (1×13×19), Des nouvelles du Brésil é uma coletânea de vinte contos apresentada por Clélia Pisa. 


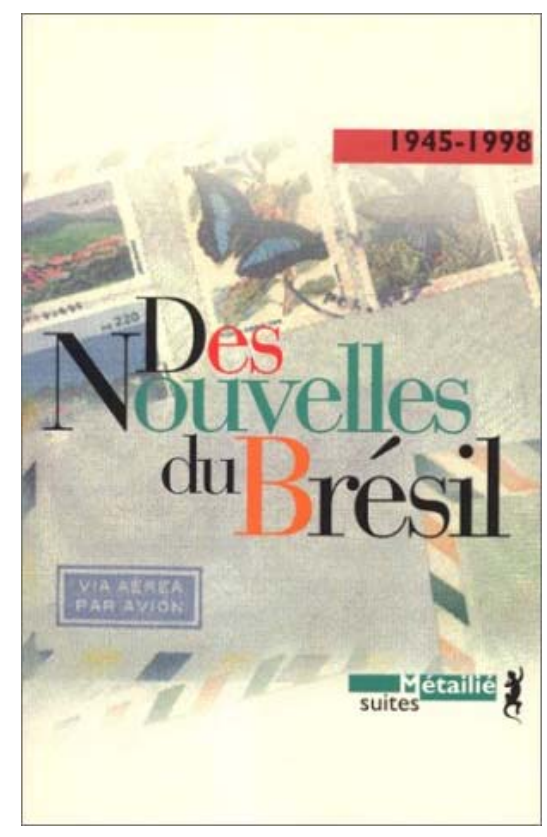

A capa - uma composição gráfica cujo crédito figura na contracapa "couverture Aparício \& Hoch" - representa envelopes de cartas sobrepostas com moldura nas cores brasileiras (esta apresenta a inscrição "via aérea-par avion") e francesas, sugerindo o diálogo entre os países e, conseqüentemente, entre as culturas em questão. Observam-se igualmente alguns selos com timbre, nos quais se vislumbram muito sutilmente, em um, uma borboleta e, em outro, uma paisagem florida. Figura na parte superior à direita o período cronológico "19451998". O título aparece numa composição gráfica, central. Na parte inferior à direita há o nome da editora "Métailié", a coleção "suites" e um lagarto, símbolo da editora.

A contracapa traz o nome da coleção, acrescido da origem dos contos na parte superior à direita "suite brésilienne", em seguida o período cronológico à esquerda "1945-1998", seguido do título corrido "Des nouvelles brésiliennes" e da indicação "présentées par Clélia Pisa". Numa disposição mais centralizada surgem os nomes dos autores:

João GUIMARÃES ROSA -

Clarice LISPECTOR - Osman LINS -

Lygia FAGUNDES TELLES -

Dalton TREVISAN - Rubem FONSECA - 


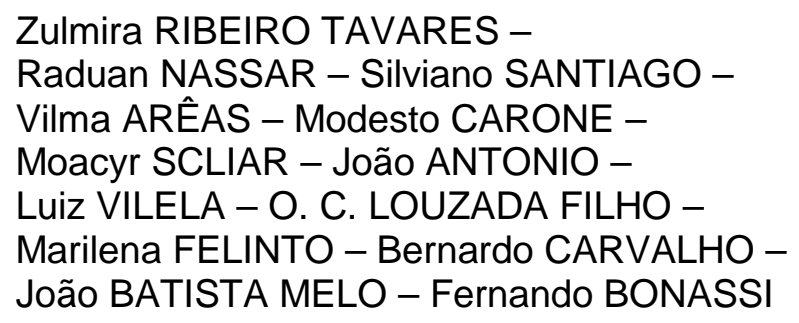

$\mathrm{Na}$ parte inferior, observa-se o código de barras, o nome e endereço da editora, o crédito da ilustração da capa, número ISBN, indicação "Diffusion Seuil" e o preço.

A família Métailié é bastante cuidadosa em seus projetos editoriais. A qualidade do prefácio de Clélia Pisa é uma prova do esmero dessa publicação. Assessorada por renomados intelectuais brasileiros, muitos do meio acadêmico paulistano como o crítico literário Davi Arrigucci Jr., Pisa traça um bem elaborado panorama da história do conto no Brasil a partir de 1945.

Como curiosidade, inclui-se aqui a publicação Le goût de Rio de Janeiro, que, como citado anteriormente contém uma passagem de Un été brésilien (Agosto) que descreve a Confeitaria Colombo. Antes do trecho, porém, um pequeno texto apresenta Rubem Fonseca como "o primo carioca de James Ellroy".

Essa pequena publicação faz parte de uma coleção das Editions Mercure de France, "Le Petit Mercure. Le goût des villes", consagrada a cidades. Embora pequena nas dimensões (Poche: $11 \times 1 \times 16$ ) e nada requintada na encadernação (brochura simples), o conteúdo dessa publicação é bastante apurado. Trata-se de um pequeno guia da cidade do Rio de Janeiro, constituído por três partes ( $A$ baía do Rio, A cidade do Rio e $\mathrm{O}$ homem do Rio) em forma de antologia literária com trechos de 27 textos (com breve comentário sobre sua origem) dos mais diversos escritores: André Thévet, Paul Claudel, Stefan Zweig, John dos Passos, John Updike e Georges Bernanos. 

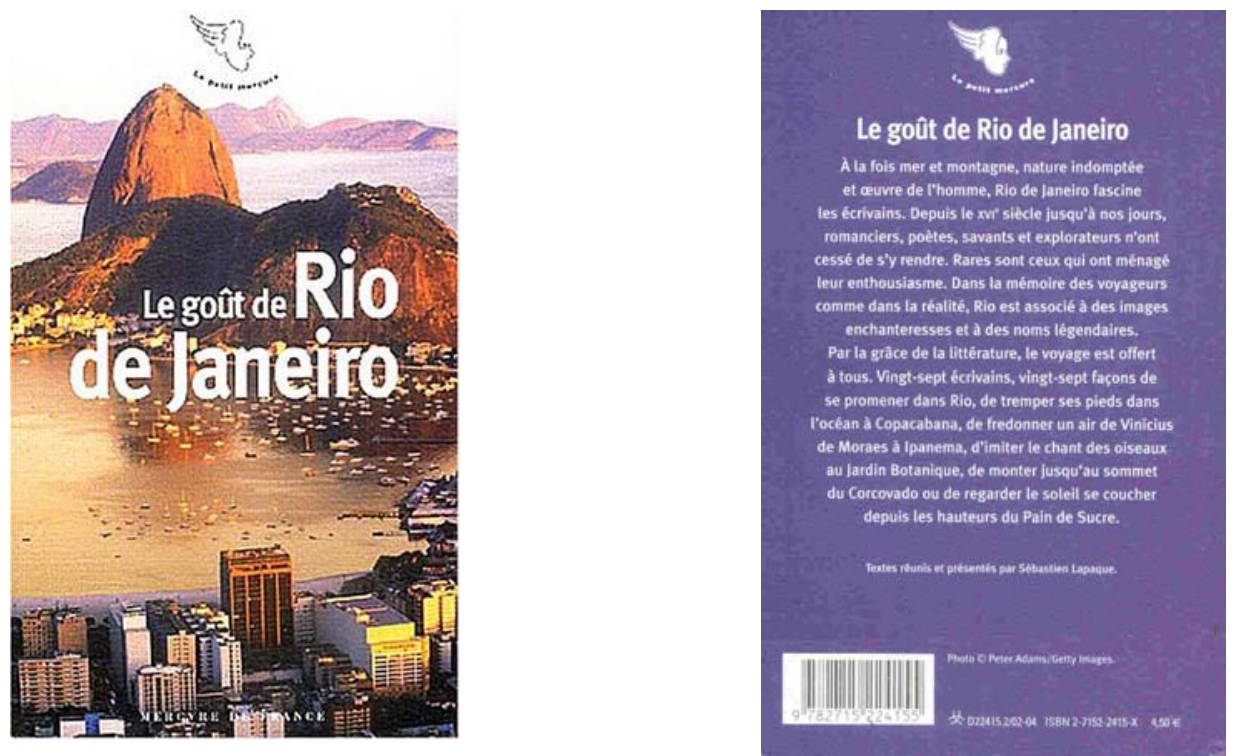

A capa apresenta uma foto do crepúsculo carioca, com o Pão de Açúcar ao fundo. Na parte superior figura o emblema da editora, um rosto alado com o nome da coleção "Le Petit Mercure". O título está centralizado. Na parte inferior há o nome da editora "Mercure de France". Na contracapa, figura novamente o símbolo da editora com o nome da coleção e, em seguida, um pequeno texto apresenta o conteúdo da publicação:

À la fois mer et montagne, nature indomptée et œuvre de l'homme, Rio de Janeiro fascine les écrivains. Depuis le $X V l^{e}$ siècle jusqu'à nos jours, romanciers, poètes, savants et explorateurs n'ont cessé de s'y rendre. Rares sont ceux qui ont ménagé leur enthousiasme. Dans la mémoire des voyageurs comme dans la réalité, Rio est associé à des images enchanteresses et à des noms légendaires. Par la grâce de la littérature, le voyage est offert à tous. Vingt-sept écrivains, vingt-sept façons de se promener dans Rio, de tremper ses pieds dans l'océan à Copacabana, de fredonner un air de Vinícius de Moraes à Ipanema, d'imiter le chant des oiseaux au Jardin Botanique, de monter jusqu'au sommet du Corcovado ou de regarder le soleil se coucher depuis les hauteurs du pain de Sucre. ${ }^{66}$

\footnotetext{
66 "Ao mesmo tempo mar e montanha, natureza indômita e obra humana, o Rio de Janeiro fascina os escritores. Desde o século XVI até hoje, romancistas, poetas, cientistas e exploradores não pararam de visitá-lo. Raros são aqueles que controlaram seu entusiasmo. Na memória dos viajantes, como na realidade, o Rio está associado a imagens sedutoras e nomes lendários. Por mercê da literatura, a viagem está à disposição de todos. Vinte e sete escritores, vinte e sete maneiras de passear pelo Rio, de molhar os pés no oceano em Copacabana, de cantarolar uma
} 
Abaixo do texto, a precisão "Textes réunis et présentés par Sébastien Lapaque". Na parte inferior, o código de barras, crédito da foto da capa, indicações ISBN e o preço: 4,5 euros.

O livro traz ainda uma introdução de cinco páginas do organizador, escrita em 19 de julho de 2003, na llha de Paquetá.

\section{Capas, contracapas e entornos de livros}

Materialmente, no que se refere à capa e contracapa das edições franceses, a edição da Flammarion é em "broché" $15 \mathrm{~cm} \times 21 \mathrm{~cm}$, e todas as edições da Grasset são em "broché" $14 \mathrm{~cm} \times 22,5 \mathrm{~cm}$, ou seja, trata-se de uma edição mais refinada que as edições de bolso, por exemplo ${ }^{67}$ Os preços variavam, na época do lançamento, entre FF79 e FF129 - atualmente entre 10 e 25 euros. A grande arte/Du grand art e Agosto/Un été brésilien receberam posteriormente nova edição em "livre de poche broché" $18 \mathrm{~cm} \times 11 \mathrm{~cm}$, mais popular, valendo aproximadamente entre 5 e 10 euros atualmente. ${ }^{68}$

\section{Le cas morel suivi de Bonne et heureuse année}

melodia de Vinícius de Moraes em Ipanema, de imitar o canto dos pássaros no Jardim Botânico, de subir ao pico do Corcovado ou olhar o sol se pôr das alturas do Pão de Açúcar."

67 A edição simples, chamada "broché" na França, corresponde ao acabamento "brochura" no Brasil, e assim será doravante denominada. Essa técnica de encadernação se contrapõe à da edição de bolso, mais popular, e à de capa dura, mais requintada.

${ }^{68} \mathrm{O}$ popular "livre de poche" francês será doravante denominado "livro de bolso". 

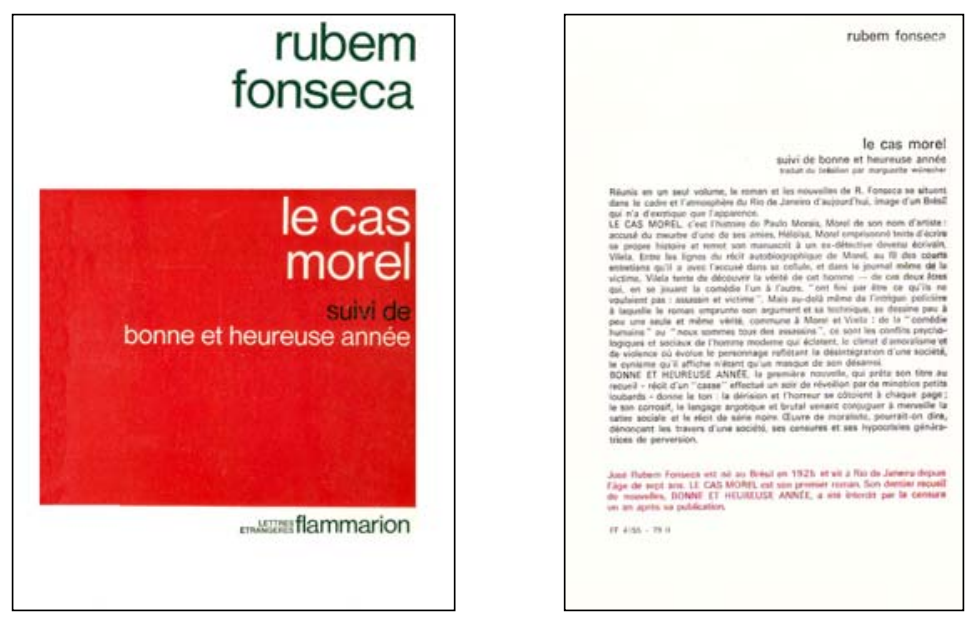

A capa da edição da Flammarion, de 1979, é bastante simples, sem ilustração. O papel é fosco. O texto da capa compreende: autor, título e editora em branco ou em preto, e a única cor presente é o destaque, em quadro vermelho, dos títulos do romance, Le cas morel, mais destacado, e da coletânea de contos Bonne et heureuse année, com menor destaque. Optou-se por utilizar apenas letras minúsculas, fato que reforça a simplicidade visual. Por fim, figura abaixo do quadro vermelho a indicação da coleção "Lettres étrangères" junto à editora "Flammarion". Não há indicação da tradutora Margueritte Wünscher nem menção à origem ou natureza da obra na capa.

Eis o texto integral da contracapa: 
Réunis en un seul volume, le roman et les nouvelles de $R$. Fonseca se situent dans le cadre et l'atmosphère du Rio e Janeiro d'aujourd'hui, image d'un Brésil qui n'a d'exotique que l'apparence.

LE CAS MOREL, c'est l'histoire de Paulo Morais, Morel de son nom d'artiste: accusé du meurtre d'une de ses amies, Héloïsa, Morel emprisonné tente d'écrire sa propre histoire et remet son manuscrit à un ex-detective devenu écrivain, Vilela. Entre les lignes du récit autobiographique de Morel, au fil des courts entretiens qu'il a avec l'accusé dans sa cellule, et dans le journal même de la victime, Vilela tente de découvrir la vérité de cet homme - et de ces deux êtres qui, en se jouant la comédie l'un à l'autre, "ont fini par être ce qu'ils ne voulaient pas: assassins et victime". Mais au-delà même de l'intrigue policière à laquelle le roman emprunte son argument et sa technique, se dessine peu à peu une seule et même vérité, commune à Morel et Vilela: de la "comédie humaine" où "nous sommes tous des assassins", ce sont les conflits psychologiques et sociaux de l'homme moderne qui éclatent, le climat d'amoralisme et de violence où évolue le personnage reflétant la désintégration d'une société, le cynisme qu'il affiche n'étant qu'un masque de son désarroi.

BONNE ET HEUREUSE ANNÉE, la première nouvelle, qui prête son titre au reccueil - récit d'un "casse" effectué un soir de réveillon par de minables petits loubards - donne le ton: la dérision et l'horreur se côtoient à chaque page; le ton corrosif, le langage argotique et brutal venant conjuguer à merveille la satire sociale et le récit de série noire. Oeuvre de moraliste, pourrait-on dire, dénonçant les travers d'une société, ses censures et ses hypocrisies génératrices de perversion.

José Rubem Fonseca est né au Brésil en 1925 et vit à Rio de Janeiro depuis l'âge de sept ans. LE CAS MOREL est son premier roman. Son dernier recueil de nouvelles, BONNE ET HEUREUSE ANNÉE, a été interdit par la censure un an après sa publication. ${ }^{69}$

\footnotetext{
69 "O CASO MOREL

Seguido de Feliz ano novo

Traduzido do português do Brasil por Marguerite Wünscher
}

Reunidos em um único volume, o romance e os contos de R. Fonseca situam-se no cenário e na atmosfera do Rio de Janeiro atual, imagem de um Brasil que só é exótico em aparência.

O CASO MOREL, é a historia de Paulo Morais - Morel é seu nome artístico. Acusado da morte de uma de suas amigas, Heloisa, Morel preso, tenta escrever sua própria história e envia o manuscrito a um ex-detetive que se tornara escritor, Vilela. Entre as linhas da narrativa autobiográfica de Morel, no curso das breves conversas que ele tem com o acusado em sua cela e no próprio diário da vítima, Vilela tenta descobrir a verdade deste homem - e desses dois seres que, representando um para o outro, 'acabaram por ser o que não queriam: assassino e vítima'. Mas para além mesmo da intriga policial, da qual o romance empresta o argumento e a técnica, esboça-se, pouco a pouco, uma única e mesma verdade, comum a Morel e Vilela: a 'comédia humana' onde 'somos todos assassinos', são os conflitos psicológicos e sociais do homem moderno que explodem, o clima amoral e de violência no qual se move a personagem, refletindo a desintegração de uma sociedade, e o cinismo que ele demonstra, sendo apenas uma máscara de sua angústia.

"Feliz ano novo", o primeiro conto, que serve de título à coletânea - narrativa de um assalto realizado em uma noite de Ano Novo por miseráveis ladrõezinhos - dá o tom: o escárnio e o horror, rivalizam a cada página; o tom corrosivo, a linguagem gíria e brutal que vem combinar 
$\mathrm{Na}$ contracapa encontra-se novamente o título do romance em destaque, seguido do título da coletânea de contos e do crédito à tradutora, Marguerite Wünscher. O texto explica que estão reunidos em um só volume a tradução de duas obras de publicação independente no original. Apesar de enfatizar o cenário como sendo o Rio de Janeiro, busca-se já no primeiro parágrafo convidar o leitor a uma empreitada menos exótica que de costume, segundo o que pode ser observado, por exemplo, quanto às publicações de Jorge Amado na França. Sugere, dessa forma, um outro horizonte de expectativa ao leitor. Segue o resumo do romance policial (c'est l'histoire de Paulo Morais, Morel de son nom d'artiste: accusé du meurtre d'une de ses amies [...] en se jouant la comédie l'un à l'autre, "ont fini par être ce qu'ils ne voulaient pas: assassins et victime"), evidenciando aspectos estéticos e existenciais mais profundos (Mais au-delà même de l'intrigue [...] le cynisme qu'il affiche n'étant qu'un masque de son désarroi).

$\mathrm{Na}$ apresentação de Bonne et heureuse année, uma tentativa de metatexto emprega timidamente algumas poucas gírias: casse, que significa "roubo" e minables petits loubards, correspondente a "uns ladrõezinhos de merda". Nota-se que a editora apresenta um autor e um texto comprometidos com uma ideologia de denúncia social. Destacam-se, pois, as características mais prementes de Fonseca: a derrisão e o horror, o tom corrosivo, a linguagem gíria e brutal muito bem aliada à sátira social e à narrativa policial. Enfim, apresenta-se uma obra moralista que denuncia pelo viés da sociedade suas censuras e suas hipocrisias geradoras de perversão.

Um parágrafo final apresenta o autor e contém data e local de seu nascimento, assim como sua residência desde os sete anos de idade no Rio de Janeiro, e contextualiza as duas obras, o primeiro romance e a última coletânea de contos. Pode-se observar que é enfatizado o fato de Bonne et heureuse année

maravilhosamente a sátira social e a narrativa de série noir. Obra de moralista, poderíamos dizer, denunciando as falhas de uma sociedade, suas censuras e suas hipocrisias que geram a perversão.

José Rubem Fonseca nasceu no Brasil em 1925 e vive no Rio de Janeiro desde os sete anos de idade. O CASO MOREL é seu primeiro romance. Sua primeira coletânea de contos, FELIZ ANO NOVO, foi proibida pela censura um ano após sua publicação." 
ter sido censurado um ano após sua publicação. Trata-se da introdução do autor brasileiro na França, em 1979, por intermédio da tradução de seu primeiro romance (publicado em 1973, no Brasil) e da então mais recente coletânea de contos (publicada em 1975, no Brasil), respectivamente seis e quatro anos após a publicação do original no Brasil. Esse último parágrafo justifica a escolha editorial a partir da seleção de gênero romance, mais privilegiado entre os leitores franceses, porém acrescenta igualmente a razão pela qual optou-se por publicar conjuntamente a última coletânea de seus contos pelo veio ideológico ao citar a censura da obra no Brasil.

\section{Du grand art}

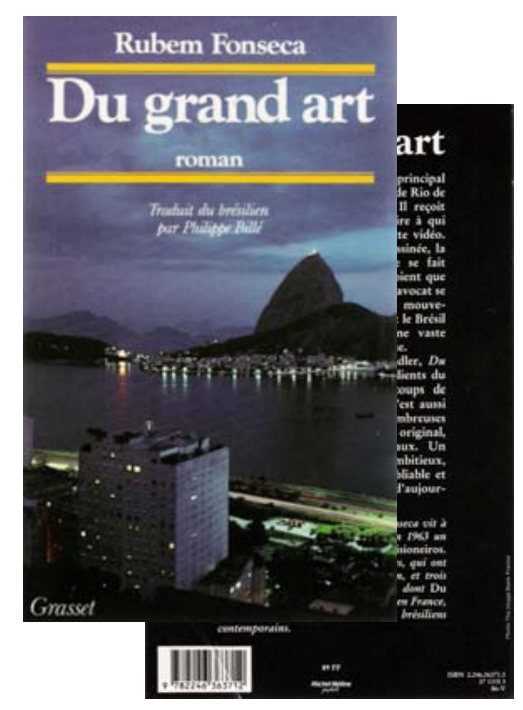

A edição de Du grand art de 1986 mostra uma foto (informação fornecida na contracapa vertical sobre o ISBN, sem autoria: The Image Bank-France) de paisagem carioca ao anoitecer. Trata-se da Baía de Guanabara com o Pão de Açúcar ao fundo. Em destaque, na parte superior da capa, em letras brancas, aparecem o nome do autor, o título do romance com a especificação roman, entre dois traços amarelos e o crédito ao tradutor: Traduit du brésilien par Philippe Billé. Esse será o único romance a apresentar essa especificação na capa. Na parte inferior, à esquerda, observa-se o nome da editora Grasset. 
Compreende-se a utilização da imagem do Pão de Açúcar por ser símbolo do Rio de Janeiro, onde se inicia e se passa parte da trama. No entanto, pode-se igualmente considerar bastante exótico o estilo "cartão postal" da capa e intencional da parte da editora, pois esse é o tipo de capa que pode induzir o leitor à compra do livro, sugerindo um conteúdo mais exótico.

A contracapa traz a sinopse do romance e a breve biografia do autor, evidenciando o lugar onde vive, sua profissão e os prêmios que o destacaram.

\section{Du grand art}

Le narrateur - et personnage principal de Du grand art - est un avocat de Rio de Janeiro, surnomé Mandrake. Il reçoit un jour la visite d'un miliardaire à qui une prositituée a volé une cassette vidéo. Peu après, la prostituée est assassinée, la cassette disparaît, et Mandrake se fait agresser par des hommes qui croient que la cassette est en sa possession. L'avocat se lance alors dans une enquête mouvementée qui lui fait traverser tout le Brésil et lui permet de découvrir une vaste organisation de trafic de cocaïne.

Thriller à la Raymond Chandler, Du grand art possède tous les ingrédients du genre: poursuites, suspense, coups de théâtre, sexe et violence. Mais c'est aussi un vrai roman littéraire aux nombreuses références artistiques, au style original, aux dialogues drôles et brutaux. Un roman à la fois divertissant et ambitieux, qui nous offre la peinture inoubliable et cruelle de la société brésilienne d'aujourd'hui.

Né en 1925 au Brésil, Rubem Fonseca vit à Rio de Janeiro. Avocat, il publie en 1963 un reccueil de nouvelles intitulé Os Prisioneiros. Depuis, il a écrit six autres ouvrages, qui ont tous reçu un prix littéraire brésilien, et trois scénarios de films. Rubem Fonseca, dont Du grand art est le premier livre publié en France, est un de plus célèbres auteurs brésiliens contemporains. ${ }^{70}$

\footnotetext{
70 "A grande arte

O narrador - e personagem principal de $A$ grande arte - é um advogado do Rio de Janeiro, apelidado Mandrake. Ele recebe um dia a visita de um bilionário a quem uma prostituta roubou uma fita de vídeo. Pouco depois a prostituta é assassinada, a fita desaparece e Mandrake é agredido por homens que acreditam que ele está com a fita. O advogado se lança, então, em uma investigação movimentada que o faz atravessar todo o Brasil e lhe permite descobrir uma vasta organização de tráfico de cocaína.

Triller à moda de Raymond Chandler, $A$ grande arte possui todos os ingredientes do gênero: perseguições, suspense, peripécias, sexo e violência. Mas é também um verdadeiro romance literário com inúmeras referências artísticas, de estilo original, com diálogos engraçados e brutais. Um romance ao mesmo tempo divertido e ambicioso, que nos oferece o quadro inesquecível e cruel da sociedade brasileira atual.

Nascido em 1925 no Brasil, Rubem Fonseca vive no Rio de Janeiro. Advogado, publica em 1963 uma coletânea de contos intitulada Os prisioneiros. Desde então, escreveu seis outras obras, que receberam todas um prêmio literário brasileiro e três roteiros de filmes. Du grand Art é o primeiro
} 
Impossível não atentar para o paralelismo das informações iniciais quanto à cidade e ao personagem do romance e seu autor: ambos vivem no Rio de Janeiro e são advogados. O texto sugere que o autor é grande conhecedor do assunto sobre o qual discorrerá. O primeiro parágrafo fornece de imediato todos os ingredientes da intriga de um romance policial: um advogado, um milionário, uma prostituta, uma fita de vídeo, um assassinato, o desaparecimento da fita cassete, a agressão ao advogado, uma busca desenfreada pelo Brasil afora e o tráfico de cocaína. Essa informação é retomada no parágrafo seguinte, que se inicia comparando Rubem Fonseca ao conceituado escritor americano de romances policiais Raymond Chandler. Uma vez lançada a informação sobre o gênero literário em questão: thriller - romance policial, ressalta-se que se trata igualmente de um romance literário de valor: "Mais c'est aussi un vrai roman littéraire aux nombreuses références artistiques, au style original, aux dialogues drôles et brutaux ". A conclusão visa seduzir o leitor potencial indicando três pontos de seu provável interesse, qualificando o romance como prazeroso ou divertido (divertissant), escrito tanto com erudição estilística (ambitieux) quanto com erudição sociológica (qui nous offre la peinture inoubliable et cruelle de la société brésilienne d'aujourd'hui).

No que concerne à apresentação do autor, as datas e a menção aos prêmios revelam um escritor maduro, experiente e reconhecido no Brasil, porém recente na França. Reforça ainda o teor de "novidade" a informação, aliás incorreta, que se trata da primeira tradução de um romance de Rubem Fonseca para a língua francesa. Como se verá adiante, repetidamente, a Grasset irá ignorar a publicação da Flammarion, O caso Morel, traduzido e publicado em 1979 na França. O final da apresentação mesclará mais uma vez o caráter inovador e moderno do autor, assim como a relevância em sua publicação em francês pelo fato de ser um dos mais célebres escritores brasileiros contemporâneos.

livro de Rubem Fonseca, um dos mais famosos autores brasileiros contemporâneos publicados na 


\section{Bufo \& Spallanzani}

Tanto Bufo \& Spallanzani quanto Vastes émotions et pensées imparfaites receberam tratamento especial.

Bufo \& Spallanzani, lançado em janeiro de 1989 na França, é a primeira das edições da Grasset a apresentar uma capa diferenciada das edições precedentes. Uma primeira capa, em papel couché brilhante 120gr, pode ser descartada e cobre o livro, protegendo-o. Essa capa traz uma ilustração de Ken Woodard (informação figurando na contracapa couché - apenas, deitada em vertical - à direita da inscrição ISBN: Illustration Ken Woodard) representando o Pão de Açúcar, durante o dia. Em primeiro plano, a parte dianteira de um carro luxuoso cujo estandarte dianteiro sobre o painel frontal é um sapo. Mais uma vez, pode-se observar o Pão de Açúcar como cartão postal da cidade do Rio de Janeiro, onde se passa a trama. O carro de luxo, em primeiro plano, sugere uma relação de poder monetário na intriga. O sapo no capô do carro é uma alusão ao cientista Spallanzani, descobridor do veneno que será um elemento utilizado no romance. Dessa forma, o Pão de Açúcar anuncia o espaço, porém somente após a leitura do livro é que se compreende o restante dos elementos da ilustração. No mínimo, as informações visuais dessas duas primeiras capas da Grasset conduzem o leitor/comprador a deduzir que autor e obra estão vinculados à cidade do Rio de Janeiro.

Esta sobrecapa apresenta uma orelha com a foto do autor e o seguinte texto:

Rubem Fonseca est né en 1925 au Brésil. Avocat depuis 1948, il s'est également illustré dans le journalisme, l'enseignement et la critique cinématographique. Depuis 1963, il a publié trois scénarios, et sept romans dont Du grand art, paru chez Grasset en $1986 .{ }^{71}$

França."

71 "Rubem Fonseca nasceu em 1925 no Brasil. Advogado desde 1948, ele também se destacou no jornalismo, no magistério e na crítica cinematográfica. De 1963 até hoje, publicou três roteiros e sete romances entre os quais A grande arte, publicado pela Editora Grasset em 1986." 
Nota-se que a apresentação do autor é mais sucinta que na edição de $D u$ Fonseca grand art. Mantém-se a informação sobre sua origem e sua profissão, sem a menção à sua residência no Rio de Janeiro. Também há indicação de suas publicações, sem maiores detalhes. Informa-se igualmente que Du grand art foi publicado anteriormente pela Grasset. Omite-se, dessa vez, a informação, errônea, como já mencionamos, de que se tratava de uma primeira publicação de Rubem Fonseca em francês, mas não se revela a publicação de estréia de Fonseca pela Flammarion.

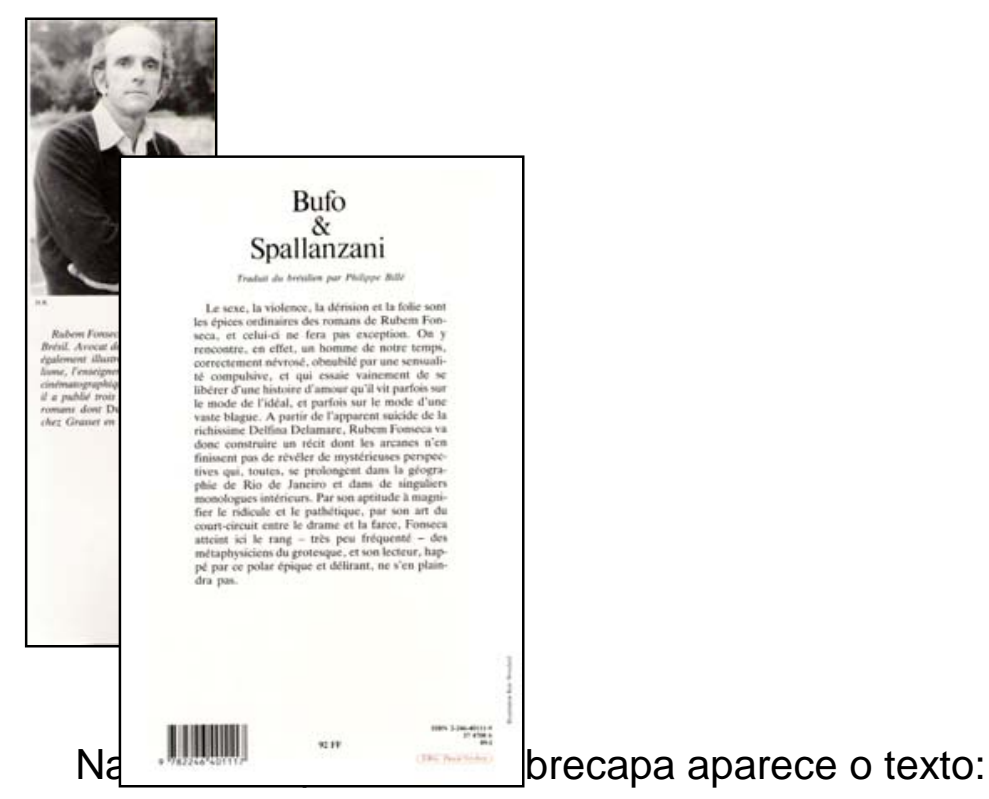

Bufo
$\&$
Spallanzani

Traduit du brésilien par Philippe Billé

Le sexe, la violence, la dérision et la folie sont les épices ordinaires des romans de Rubem Fonseca, et celui-ci ne fera pas exception. On y rencontre, en effet, un homme de notre temps, correctement névrosé, obnubilé par une sensualité compulsive, et qui essaie vainement de se libérer d'une histoire d'amour qu'il vit parfois sur le mode de l'idéal, et parfois sur le mode d'une vaste blague. A partir de l'apparent suicide de la richissime Delfina Delamare, Rubem Fonseca va donc construire un récit dont les arcanes n'en finissent pas de révéler de mystérieuses perspectives qui, toutes, se prolongent dans la 
géographie de Rio de Janeiro et dans des singuliers monologues intérieurs. Par son aptitude à magnifier le ridicule et le pathétique, par son art du coutcircuit entre le drame et la farce, Fonseca atteint ici le rang - très peu fréquenté - des métaphysiciens du grotesque, et son lecteur, happé par ce polar épiqué et délirant, ne s'en plaindra pas. ${ }^{72}$

Mais uma vez, a apresentação do romance, assim como em Du grand art, enfocará os principais ingredientes de um bom romance policial que se passa no Rio de Janeiro: sexo, violência, derrisão, loucura são listados como o tempero característico de Rubem Fonseca. Além desses ingredientes, o protagonista será descrito como um homem contemporâneo, neurótico, obcecado sexual. Anunciamse, quanto à narrativa, o cenário carioca e a característica dos monólogos internos. As qualidades do escritor como "metafísico do grotesco" são exaltadas. Ressalta-se sua habilidade em lidar com o ridículo e o patético, na combinação eletrizante do drama e da farsa, garantindo ao leitor plena satisfação. O texto combina elementos sedutores tanto para o leitor de romances policiais quanto para um leitor que busca uma literatura mais elaborada.

Quando retirada a cobertura em papel couché brilhante, pode-se notar o livro com capa bastante sóbria em papel plissê 180gr amarelo-claro. Nela figuram, justificados à direita, inicialmente o nome do autor brasileiro (em verde), o título em duas cores (marrom e verde) com a especificação roman e a inscrição "Traduit du brésilien par Philippe Billé". Mais abaixo, figura o nome da editora Grasset, tudo em verde. Na contracapa, há o título do romance em marrom e, em verde, o texto da orelha em couché (itálico) e o da contracapa couché (normal), em verde.

\footnotetext{
72 "Bufo \& Spallanzani

Traduzido do português do Brasil por Philippe Billé

O sexo, a violência, a angústia e a loucura são os temperos comuns dos romances de Rubem Fonseca e este não será exceção. Encontra-se nele, de fato, um homem de nosso tempo, absolutamente neurótico, obnubilado por uma sensualidade compulsiva e que tenta em vão se liberar de uma história de amor que ele vive às vezes idealmente e às vezes como uma enorme pilhéria. A partir do aparente suicídio da riquíssima Delfina Delamare, Rubem Fonseca vai construir uma narrativa, cujos arcanos não param de revelar misteriosas perspectivas que, sem exceção, se prolongam na geografia do Rio de Janeiro e em singulares monólogos interiores. Por sua aptidão em tornar grandiosos o ridículo e o patético, por sua arte do curto-circuito entre o drama e a farsa, Fonseca atinge aqui a posição - alcançada por poucos - dos metafísicos do grotesco e, seu leitor, tragado por esse polar épico e delirante, não terá do que se queixar."
} 


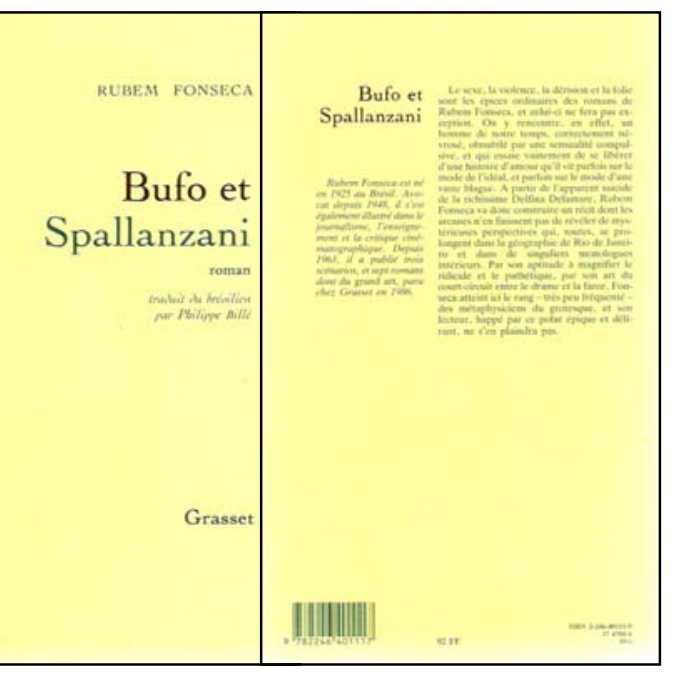

Vastes émotions et pensées imparfaites

No que concerne à capa em couché de Vastes émotions et pensées imparfaites, há o nome do autor bem evidenciado, em seguida a foto, da agência européia Zefa, de um destaque no carnaval (informação fornecida sucintamente na contracapa couché, somente, em vertical sobre o ISBN: Photo Zefa), a especificação roman, o título da obra e o nome da editora Grasset. Pode-se ver na fotografia da capa um duplo efeito. Primeiramente, o aspecto iminentemente exótico em se utilizar essa imagem. Somente após a leitura do romance pode-se compreender a função das fantasias de carnaval na intriga, justificando então a 
escolha da foto. O leitor desavisado poderá, no entanto, pensar que a foto é representativa do tema do romance, e não apenas um elemento da trama. $O$ resumo da contracapa não esclarece a relação da foto com o romance; ao contrário, ao ler o resumo, pode-se perguntar o que um destaque de escola de samba estaria fazendo na capa do livro. Há efetivamente na trama um personagem, Negromente, que nunca consegue o primeiro prêmio no concurso de fantasias do carnaval carioca, e que terá participação na resolução da intriga. Porém, sem se ter acesso ao enredo e a essa figura, pode-se, mais uma vez, assim como se verificou no que se refere às capas com a foto e ilustração do Pão de Açúcar, pensar inicialmente em uma mera estratégia editorial. É fato que, a cada publicação, Rubem Fonseca será identificado como um autor vinculado ao Rio de Janeiro. Dessa forma, apesar do componente exótico e apelativo, mais uma vez a opção gráfica contempla tanto o enredo quanto o apelo comercial.

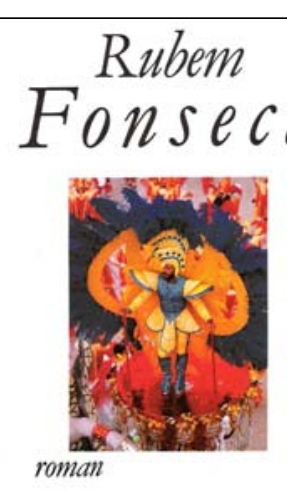

Vastes émotions et pensées imparfaites

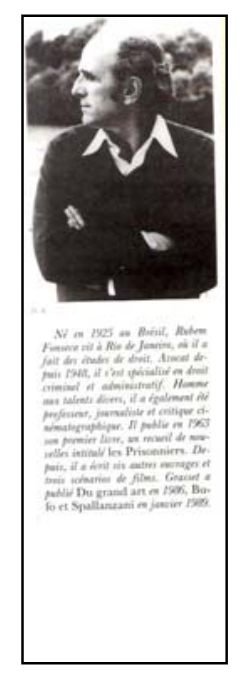


A capa apresenta uma orelha contendo uma foto do autor e o seguinte texto:

Né em 1925 au Brésil, Rubem Fonseca vit à Rio de Janeiro, ou il a fait des études de droit. Avocat depuis 1948, il s'est spécialisé en droit criminel et administratif. Homme aux talents divers, il a également été professeur, journaliste et critique cinématographique. II publie en 1963 son premier livre, un recueil de nouvelles intitulé Les prisionniers. Depuis, il a écrit six autres ouvrages et trois scénarios de films. Grasset a publié Du grand art en 1986, Bufo et Spallanzani en janvier $1989 .{ }^{73}$

Essa apresentação do autor conjuga informações presentes tanto na edição de Du grand art quanto em Bufo \& Spallanzani. Nascimento e residência, estudos e profissão, sucintamente sua produção e as duas edições da Grasset.

A contracapa em couché traz o seguinte texto:

\section{Vastes émotions et pensées imparfaites}

Traduit du portugais (brésilien) par Philippe Billé

"Quelle sensation ambigüe de peur et d'euphorie, que de se sentir poursuivi par un tueur! Comme il est bon d'avoir une base réelle pour sa propre paranoïa!" A ce point de mon raisonnement, je me mis à élaborer un script. Un type obtient par hasard des bijoux qui sont le produit d'un crime et il est poursuivi par une bande de dangereux malfaiteurs. L'homme ne veut pas garder les bijoux, il n'a rien à en faire (ce qui n'est pas exactement mon cas), mais tant qu'il les garde en sa possession, les bandits le pourchassent. Et comme il ne veut pas que la poursuite s'arrête, il provoque ses poursuivants, etc., etc.

73 "Nascido em 1925 no Brasil, Rubem Fonseca vive no Rio de Janeiro, onde estuda direito. Advogado desde 1948, ele estudou direito criminal e administrativo. Homem de talentos diversos, foi também professor, jornalista e crítico cinematográfico. Publicou em 1963 seu primeiro livro, uma coletânea de contos intitulada Os Prisioneiros. Desde então, escreve outras obras e roteiros de filmes. Grasset publicou A grande arte em 1986, Bufo et Spallanzani em janeiro de1989.“ 
Au fil des pages, le lecteur se mue en poursuivant, constamment provoqué, aiguillonné par Rubem Fonseca. De Rio à Berlin, des voleurs, des femmes, des diamants, des manuscrits forment sous la plume de ce grand écrivain brésilien un ballet frénétique et envoûtant, duquel il n'est pas aisé de sortir. ${ }^{74}$

Essa é a primeira contracapa francesa a apresentar o romance de Rubem Fonseca a partir de um trecho dele extraído, como se pode notar no primeiro parágrafo. Já no segundo parágrafo, o texto, explicativo, retoma os elementos característicos de um romance policial, buscando seduzir o leitor.

Quando retirada a cobertura em papel couché brilhante, observa-se que esse livro tem a mesma apresentação que Bufo et Spallanzani: capa bastante sóbria em papel plissê 180gr amarelo claro. Nela figuram, igualmente justificados à direita, inicialmente o nome do autor brasileiro (em verde), o título em duas cores (marrom e verde) com a especificação roman e a inscrição "Traduit du brésilien par Philippe Billé". Mais abaixo, consta o nome da editora Grasset, tudo em verde. Na contracapa, têm-se o título do romance, em marrom, e, em verde, o texto da orelha em couché (itálico) e o da contracapa couché (normal), em verde.

\footnotetext{
74 "Vastas emoções e pensamentos imperfeitos

Traduzido do português (do Brasil) por Philippe Billé

'Que sensação ambígua de medo e de euforia, sentir-se perseguido por um assassino! Como é bom ter uma base real para sua própria paranóia!' Nesse ponto de meu pensamento, comecei a elaborar um script. Um sujeito obtém, por acaso, jóias que são produto de um crime e é perseguido por um perigoso bando de bandidos. O homem não quer ficar com as jóias, não tem o que fazer com elas (o que não é exatamente meu caso), mas enquanto as conserva com ele, os bandidos o perseguem. E como ele não quer que a perseguição pare, ele provoca seus perseguidores, etc., etc.

No decorrer das páginas, o leitor se transforma em perseguidor, constantemente provocado, alfinetado por Rubem Fonseca. Do Rio a Berlim, ladrões, mulheres, diamantes, manuscritos formam, sob a pena desse grande escritor brasileiro, um balé frenético e fascinante, do qual não é fácil escapar."
} 


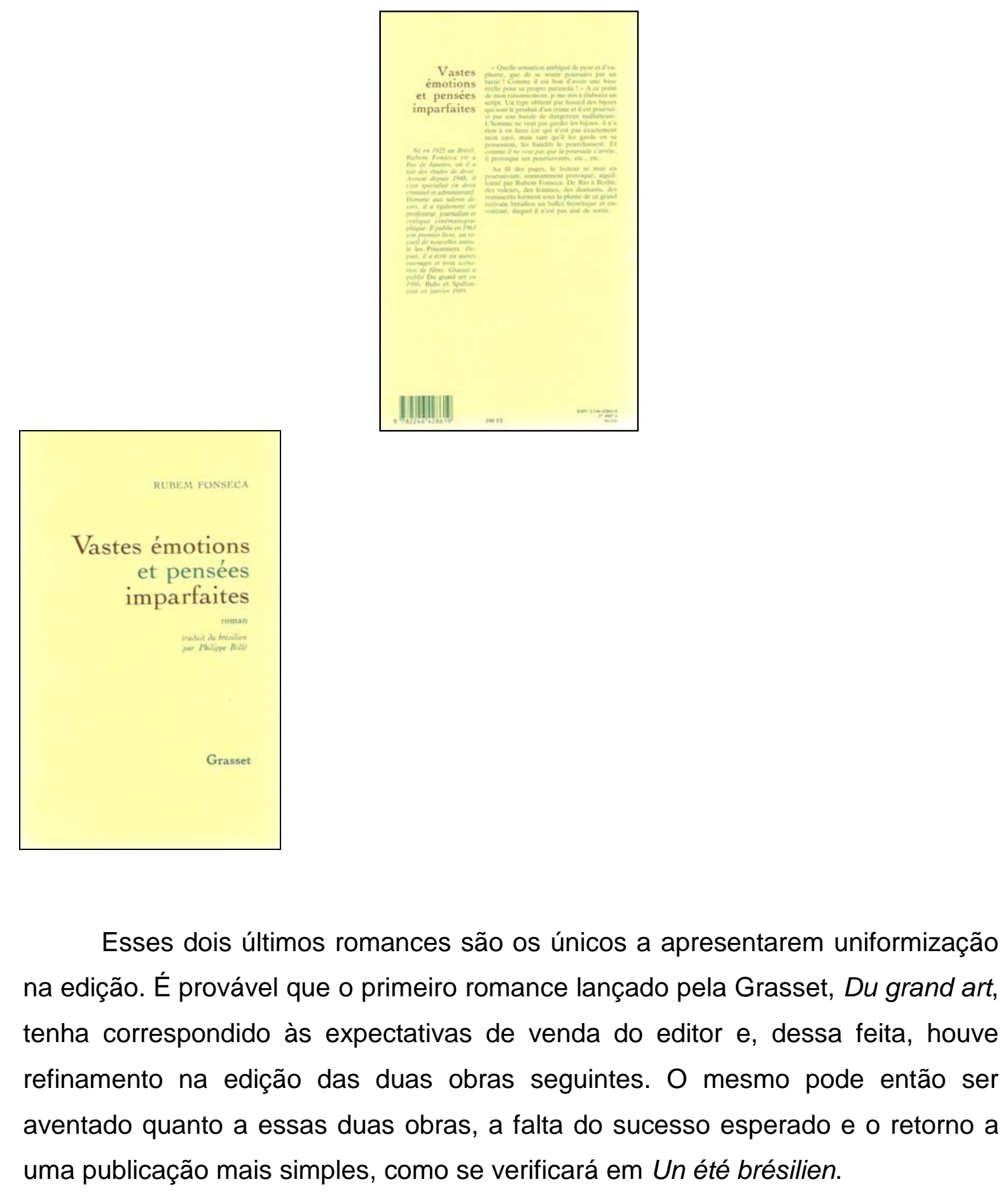

\section{Un été brésilien}


Un été brésilien, de 1993, retoma o formato mais simples de Du grand art. A capa traz destacado o nome do autor (em branco), em seguida, justificados à direita, o título da obra, com a especificação roman e abaixo a editora Grasset, tudo em amarelo sobre um fundo vermelho, negro e branco de uma foto solarizada de autoria do fotógrafo e artista plástico Philippe Sohiez (informação fornecida sucintamente na contracapa em vertical sobre o ISBN: Photo Philippe Sohiez), A foto representa em primeiro plano um homem com chapéu e bigode fumando provavelmente um charuto, em segundo plano uma mulher em pose sedutora, e ao fundo de cada figura uma palmeira ou coqueiro.

Pode-se vislumbrar aqui a intenção do artista em representar elementos do submundo (o malandro e a prostituta) em uma atmosfera tropical (charuto, palmeiras, chapéu panamá). A cor vermelha também é sugestiva: tanto do clima tropical como de uma intriga criminal. Embora se reconheça aqui a qualidade do trabalho de Philippe Sohiez, a capa não é completamente reveladora do conteúdo do romance - uma ficção histórica, mas trata-se de uma ilustração bastante sugestiva, contendo os clichês de uma capa de romance policial.

Ao se pesquisar sobre o fotógrafo e artista plástico Philippe Sohiez, verificase a preocupação na elaboração dessa capa. Segundo informações fornecidas por ele, em geral há dois procedimentos para a escolha de uma capa de livro, por parte dos editores e maquetistas, que contenha foto ou ilustração: uma encomenda ou a utilização de material já existente nos bancos de imagens ou agências de fotos, como a Getty, a Corbis e a Photonica, que acaba de ser comprada pela Getty.

Pour vous parler très brièvement de notre rôle d'illustrateur. II se limite très souvent à la lecture de l'argumentaire de la $4^{\text {ème }}$ de couverture pour se faire une idée. De nous jours les créations se font de plus en plus rares. Les éditeurs et les maquettistes puisent leurs illustrations dans des banques d'images en recherchant l'image qui convienne le mieux au roman. C'est ce que je fais actuellement avec mon site que je vous ai envoyé.

Pour en revenir à la couverture $d$ ' "Un été brésilien". C'était encore une époque où l'on réalisait encore des couvertures sur commande et comme il s'agit d'un temps déjà lointain tout était réalisé en gros sans moyens informatiques, peu répandus à l'époque. Donc globalement s'il s'agit d'un photomontage de photographies tirées de ma photothèque.

-un fond avec des palmiers 
-un personnage style mafieux d'Amérique du sud

-et une jeune femme style prostituée

Le photomontage est réalisé en découpant et en collant les images. Le tout photocopié dans un premier temps en Noir et Blanc. Par la suite J'ai utilisée une photocopieuse CANON couleur pour des virages de différentes couleurs. $^{75}$

O artista em questão também é muito conhecido por explorar elementos

insólitos do cotidiano dos bairros parisienses. Normalmente, por contemplar o

urbano em suas obras, esse seria um excelente artista para ilustrar qualquer um dos romances de Rubem Fonseca. Como interpretar a escolha dessa ilustração? Descompasso ou pista? É possível que a análise de outras opções editoriais, como o título da obra, venham elucidar essas questões.

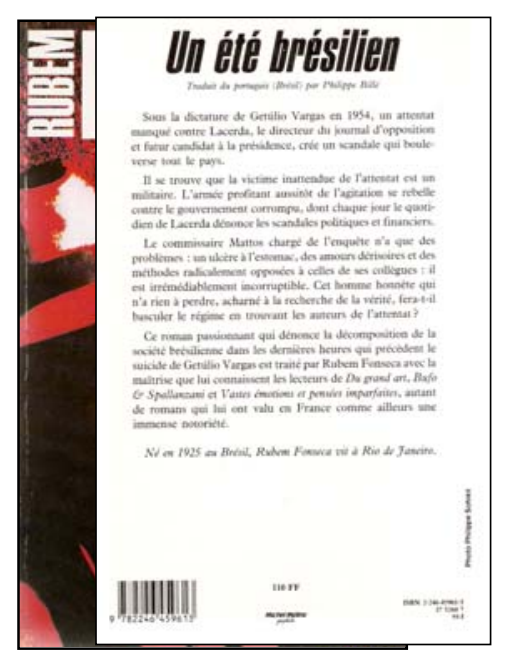

Na contracapa, encontra-se o seguinte texto:

${ }^{75}$ Depoimento obtido por e-mail, em 21.07.2005.

"Para falar bem rapidamente de nosso papel de ilustrador. Ele se limita, em geral, à leitura do comentário da $4^{a}$ capa, para ter uma idéia da história. Nos dias de hoje, as criações tornam-se cada vez mais raras. Os editores e os projetistas buscam suas ilustrações em bancos de imagens e escolhem a que convém melhor ao romance. É o que faço, atualmente, em minha página Internet que the enviei.

Para voltar à capa de "Un été brésilien", estávamos ainda na época em que se realizavam capas sob encomenda e como se trata de um tempo já longínqüo, tudo era feito em geral, sem meios informáticos, pouco difundidos na época. Portanto trata-se grosso modo de uma fotomontagem, com fotografias tiradas de meu arquivo.

- um fundo de palmeiras

- uma personagem tipo mafioso da América do Sul

- uma jovem, tipo prostituta

A fotomontagem é realizada recortando-se e colando-se as imagens. O conjunto é fotocopiado, primeiro em preto-e-branco. Em seguida eu utilizei uma copiadora CANON em cores para banhos de diferentes cores." 


\section{Un été brésilien}

\section{Traduit du portugais (Brésil) par Philippe Billé}

Sous la dictature de Getúlio Vargas en 1954, un attentat manqué contre Lacerda, le directeur du journal d'opposition et futur candidat à la présidence, crée un scandale qui bouleverse tout le pays.

II se trouve que la victime inattendue de l'attentat est un militaire. L'armée profitant aussitôt de l'agitation se rebelle contre le gouvernement corrompu, dont chaque jour le quotidien de Lacerda dénonce les scandales politiques et financiers.

Le commissaire Mattos chargé de l'enquête n'a que des problèmes: un ulcère à l'estomac, des amours dérisoires et des méthodes radicalement opposées à celles de ses collègues: il est irrémédiablement incorruptible. Cet homme honnête qui n'a rien à perdre, acharné à la recherche de la vérité, fera-t-il basculer le régime en trouvant les auteurs de l'attentat?

Ce roman passionnant qui dénonce la décomposition de la société brésilienne dans les dernières heures qui précèdent le suicide de Getúlio Vargas est traité par Rubem Fonseca avec la maîtrise que lui connaissent les lecteurs de Du grand art, Buffo \& Spallanzani et Vastes émotions et pensées imparfaites, autant de romans qui lui ont valu en France comme ailleurs une immmense notoriété.

Né en 1925 au Brésil, Rubem Fonseca vit à Rio de Janeiro. ${ }^{76}$

Há no texto, inicialmente, a parte histórica (primeiro parágrafo), e, em seguida, a inserção da ficção (segundo parágrafo). O terceiro parágrafo situa o autor, interpelando o leitor com a intimidade de quem já conhece Rubem Fonseca

\footnotetext{
76 "Agosto

Traduzido do português (do Brasil) por Philippe Billé

Sob a ditadura de Getúlio Vargas em 1954, um atentado frustrado contra Lacerda, o diretor do jornal da oposição e futuro candidato à presidência, cria um escândalo que transtorna todo o país. Acontece que a vítima inesperada do atentado é um militar. O exército, aproveitando imediatamente a agitação, rebela-se contra o governo corrupto, cujos escândalos políticos e financeiros o diário de Lacerda denuncia todos os dias.

O comissário Mattos, encarregado da investigação está cheio de problemas: uma úlcera no estômago, amores insignificantes e métodos radicalmente opostos aos de seus colegas: ele é irremediavelmente incorruptível. Este homem honesto que não tem nada a perder, obstinado na busca da verdade, derrubará o regime ao encontrar os autores do atentado?

Esse romance apaixonante que denuncia a decomposição da sociedade brasileira nas últimas horas que precedem o suicídio de Getúlio Vargas é tratado por Rubem Fonseca com a maestria que the conhecem os leitores de $A$ grande arte,, Bufo \& Spallanzani e Vastas emoões e pensamentos imperfeitos, romances que Ihe valeram na França e em toda parte uma imensa notoriedade.

Nascido em 1925 no Brasil, Rubem Fonseca vive no Rio de Janeiro."
} 
e sua obra, já que essa se trata, para a Grasset, da quarta publicação de Rubem Fonseca (e efetivamente da quinta, se o leitor conhecer também a publicação da Flammarion). Sugere, assim, que o leitor que se preza já conhece Rubem Fonseca e sua obra: "Ce roman passionnant qui dénonce la décomposition de la société brésilienne dans les dernières heures qui précèdent le suicide de Getúlio Vargas est traité par Rubem Fonseca avec la maîtrise que lui connaissent les lecteurs de Du grand art, Buffo \& Spallanzani et Vastes émotions et pensées imparfaites, autant de romans qui lui ont valu en France comme ailleurs une immmense notoriété". Dessa forma, nada mais normal do que reduzir a biografia de Rubem Fonseca a uma única linha final: "Né en 1925 au Brésil, Rubem Fonseca vit à Rio de Janeiro".

Há, no entanto, um mal-entendido histórico na apresentação: "Sous la dictature de Getúlio Vargas en 1954". Em 1954, o Brasil não vive a ditadura Vargas (1937-1945). Esse é o ano do suicídio de Vargas, e está inserido no período em que ele foi eleito pelo voto popular, em 1951.

\section{Le sauvage de l'opéra}

Cinco anos após a publicação de Agosto, Le sauvage de l'opéra (1998) se torna o romance mais recente de Rubem Fonseca lançado na França em edição brochura. A capa é em glacé, simples, e apresenta o nome do autor em itálico, em seguida a foto de uma pintura medindo $9 \mathrm{~cm} \times 7 \mathrm{~cm}$, intitulada Théâtre de la Scala, (essa informação figura na contracapa, deitada em vertical - à direita da inscrição ISBN: Didier Thimonier Photo c - AKG Photo, Mailand Théâtre de la Scala). Abaixo da gravura, há o título da obra com a especificação roman (justificada à direita) e, por fim, o nome da editora Grasset centralizado.

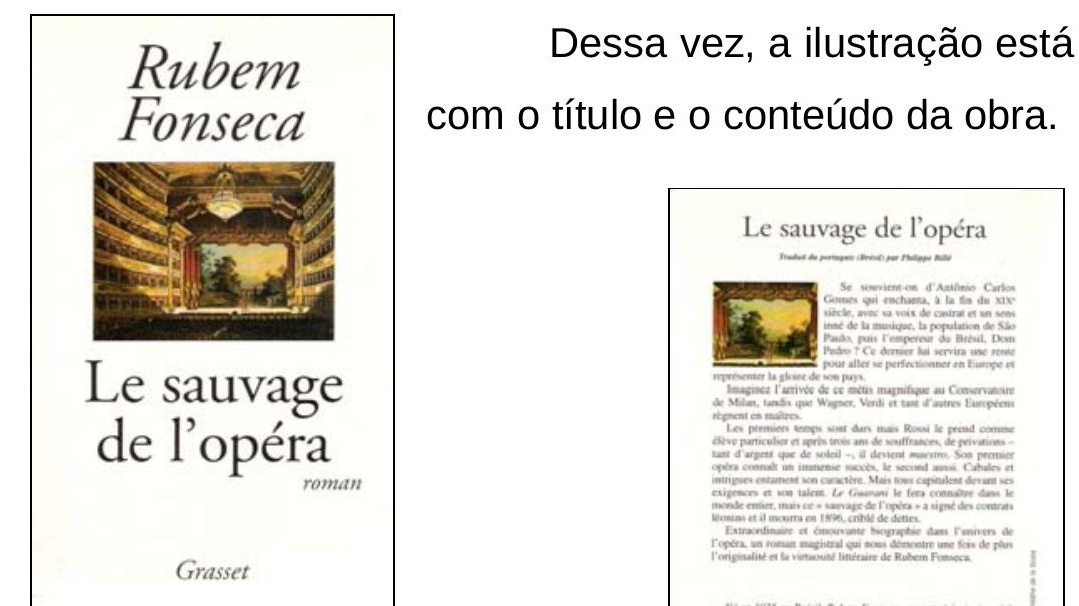


Na contracapa, há o título da obra e a especificação "Traduit du portugais (Brésil) par Philippe Billé" seguida de texto em quatro parágrafos que expõe o assunto do livro, o romance biográfico sobre Carlos Gomes, ao lado da reprodução de parte da gravura da capa (recorte apenas do palco do teatro). Em seguida, um pequeno parágrafo sobre Rubem Fonseca contém ano e local de seu nascimento, profissões (avocat et auteur), local de residência (Rio de Janeiro). No texto há ainda a menção às obras Du grand art, Bufo \& Spallanzani e Vastes émotions et pensées imparfaits. É curioso observar que, nessa apresentação, não há referência à última publicação Un été brésilien:

\section{Le sauvage de l'opéra}

Traduit du portugais(Brésil) par Philippe Billé

Se souvient-on d'Antonio Carlos Gomes qui enchanta, à la fin du XIX siècle, avec sa voix de castrat et un sens inné de la musique, la population de São Paulo, puis l'empereur du Brésil, Dom Pedro? Ce dernier lui servira une rente pour aller se perfectionner en Europe et représenter la gloire de son pays.

Imaginez l'arrivée de ce métis magnifique au Conservatoire de Milan, tandis que Wagner, Verdi et tant d'autres Européens règnent en maîtres.

Les premiers temps sont durs mais Rossi le prend comme élève particulier et après trois ans de souffrances, de privations - tant d'argent que de soleil -, il devient maestro. Son premier opéra connaît un immense succès, le second aussi. Cabales et intrigues entament son caractère. Mais tous captulent devant ses exigences et son talent. Le Guarani le fera connaître dans le monde entier, mais ce "sauvage de l'opéra" a signé des contrats léonins et il mourra en 1896, criblé de dettes. ${ }^{77}$

77 "O selvagem da ópera

Traduzido do português (do Brasil) por Philippe Billé

Lembram-se de Antonio Carlos Gomes que encantava, no fim do século XIX, com sua voz de castrato e um senso inato da música, a população de São Paulo e depois o imperador do Brasil, Don Pedro? O imperador Ihe dará um rendimento para ir se aperfeiçoar na Europa e representar a glória de seu país.

Imaginem a chegada desse mestiço magnífico no Conservatório de Milão, na época em que Wagner, Verdi e tantos outros europeus reinavam absolutos. 
Extraordinaire et émouvante biographie dans l'univers de l'opéra, un roman magistral qui nous démontre une fois de plus l'originalité et la virtuosité littéraire de Rubem Fonseca.

Né en 1925 au Brésil, Rubem Fonseca, avocat et écrivain, vit à Rio de Janeiro. Il a publié entre autres Du grand art (1986), Buffo \& Spallanzani (1989), et Vastes émotions et pensées imparfaites (1990), chez Grasset.

\section{Edições em livro de bolso}

Como já foi citado anteriormente, Du grand art e Un été brésilien receberam reedições integrais em livro de bolso (13694 e 13969, respectivamente), formato mais acessível ao grande público, sobretudo pelo preço. A respeito do livro de bolso, Genette (1987, p.20-6) considera que a "culture de poche", hoje universal, pode tanto significar a reedição a baixo custo para maior divulgação como a difusão de obras que ascederam ao "panteão dos clássicos".

\section{Du grand art}

A capa de Du grand art apresenta o nome do autor em destaque (branco sobre vermelho em fundo preto), o nome da obra (branco sobre fundo preto) e uma ilustração da artista alemã Elvira Bach (informação constando da contracapa, deitada em vertical - à direita da inscrição ISBN: Couv. Elvira Bach: Amore -c ADAGP, Paris 1995).

Os primeiros tempos foram duros, mas Rossi o toma como aluno particular e depois de três anos de sofrimentos, de privações - tanto de dinheiro como de sol - ele se torna maestro. Sua primeira ópera obtém um enorme sucesso, a segunda também. Cabalas e intrigas atingem seu caráter. Mas todos capitulam diante de suas exigências e de seu talento. O Guarani o tornará conhecido no mundo inteiro, mas esse 'selvagem da ópera' assinou contratos leoninos e morreu em 1896 crivado de dívidas.

Extraordinária e comovente biografia no universo da ópera, um romance magistral que nos demonstra, uma vez mais, a originalidade e a virtuosidade literária de Rubem Fonseca. 


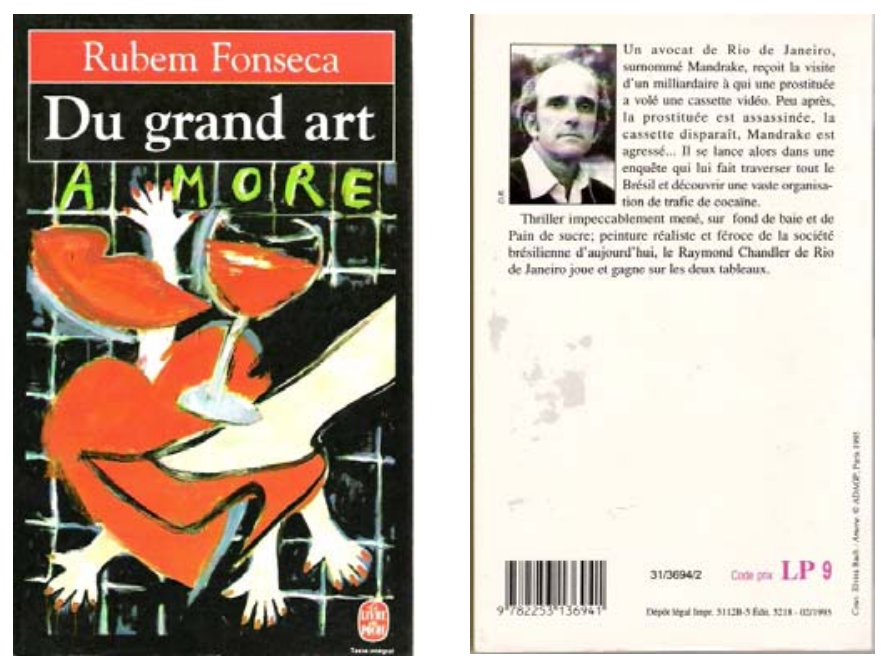

A contracapa traz a foto de Rubem Fonseca e um texto curto, resumo da edição brochura sobre o enredo da obra:

Un avocat de Rio de Janeiro, surnommé Mandrake, reçoit la visite d'un milliardaire à qui une prostituée a volé une cassatte vidéo. Peu après, la prostituée est assassinée, la cassette disparaît. Mandrake est agressé...II se lance alors dans une enquête qui lui fait traverser tout le Brésil et découvrir une vaste organisation de trafic de cocaïne.

Thriller impecablement mené, sur fond de baie et de Pain de sucre; peinture realiste et féroce de la société brésilienne d'aujourd'hui, le Raymond Chandler de Rio de Janeiro joue et gagne sur les deux tableaux. ${ }^{78}$

Na página 3 do livro, há a biografia de Rubem Fonseca, resultado da combinação de textos que figuram na contracapa da edição brochura das obras Du grand art (para a biografia e o enredo) e Bufo et Spallanzani (para a biografia)

Nascido em 1925 no Brasil, Rubem Fonseca, advogado e escritor, vive no Rio de Janeiro. Publicou, entre outros, A grande arte (1986), Bufo et Spallanzani (1989) e Vastas emoções e pensamentos imperfeitos (1990), pela editora Grasset."

78 "Um advogado do Rio de Janeiro, apelidado Mandrake, recebe a visita de um bilionário a quem uma prostituta roubou uma fita de vídeo. Pouco depois a prostituta é assassinada, a fita desaparece e Mandrake é agredido... Ele se lança, então, em uma investigação que o faz atravessar todo o Brasil e descobrir uma vasta organização de tráfico de cocaína.

Triller impecavelmente realizado, tendo como fundo a baía e o Pão de Açúcar; pintura realista e feroz da sociedade brasileira de hoje, o Raymond Chandler do Rio de janeiro representa e ganha nos dois quadros." 
e um pequeno resumo do enredo do livro, sendo este o texto integral contracapa da mesma edição brochura:

\section{Du grand art}

Rubem Fonseca est né en 1925 au Brésil. Avocat depuis 1948, il s'est également illustré dans le journalisme, l'enseignement et la critique cinématographique. Depuis 1963, il a publié trois scénario et plusieurs ouvrages qui ont tous reçu un prix littéraire brésilien. Rubem Fonseca, dont Du grand art paru chez Grasset en 1986, est le premier livre publié en France, suibi toujours chez Grasset, de Bufo et Spallanzani (1989), Vastes émotions et pensées imparfaites (1991), Un été brésilien (1993), est un de plus célèbres auteurs brésiliens contemporains

Le narrateur - et personnage principal de Du grand art - est un avocat de Rio de Janeiro, surnomé Mandrake. Il reçoit un jour la visite d'un miliardaire à qui une prositituée a volé une cassette vidéo. Peu après, la prostituée est assassinée, la cassette disparaît, et Mandrake se fait agresser pas des hommes qui croient que la cassette est en as possession. L'avocat se lance alors dans une enquête mouvementée qui lui fait traverser tout le Brésil et lui permet de découvrir une vaste organisation de trafic de cocaïne.

Thriller à la Raymond Chandler, Du grand art possède tous les ingrédients du genre: poursuites, suspense, coups de théâtre, sexe et violence. Mais c'est aussi un vrai roman littéraire aux nombreuses références artistiques, au style original, aux dialogues drôles et brutaux. Un roman à la fois divertissant et ambitieux, qui nous offre la peinture inoubliable et cruelle de la société brésilienne d'aujourd'hui. ${ }^{79}$

\footnotetext{
79 "A grande arte
}

Rubem Fonseca nasceu em 1925 no Brasil. Advogado desde 1948, também destacou-se no jornalismo, no magistério e na crítica cinematográfica. De 1963 até hoje publica três roteiros e várias obras que receberam, todas um prêmio literário brasileiro. $O$ primeiro livro publicado na França de Rubem Fonseca, um dos mais famosos autores brasileiros contemporâneos, foi $A$ grande arte, pela Grasset em 1986, seguido, sempre pela mesma editora, por Bufo et Spallanzani (1989), Vastas emoções e pensamentos imperfeitos (1991), Agosto (1993).

O narrador - e personagem principal de $A$ grande arte - é um advogado do Rio de Janeiro, apelidado de Mandrake. Ele recebe um dia a visita de um bilionário de quem uma prostituta roubou uma fita de vídeo. Pouco depois a prostituta é assassinada, a fita desaparece e Mandrake é agredido por homens que acreditam que ele está com a fita. $\mathrm{O}$ advogado se lança, então, em uma investigação movimentada que o faz atravessar todo o Brasil e lhe permite descobrir uma vasta organização de tráfico de cocaína.

Triller à moda de Raymond Chandler, $A$ grande arte possui todos os ingredientes do gênero: perseguições, suspense, peripécias, sexo e violência. Mas é também um verdadeiro romance literário com inúmeras referências artísticas, de estilo original, com diálogos engraçados e brutais. Um romance ao mesmo tempo divertido e ambicioso, que nos oferece o quadro inesquecível e cruel da sociedade brasileira atual." 


\section{Un été brésilien}

Quanto à capa da edição em livro de bolso de Un été brésilien, o nome do autor e o título da obra aparecem em destaque (branco e preto sobre fundo verde de dois tons diferentes) sobre uma foto de autoria de Thierry Campion (informação figurando na contracapa, deitada em vertical - à direita da inscrição ISBN: Photo Thierry Campion / Gamma - Bernard Flageul), na qual um policial militar brasileiro revista um jovem negro. Ao fundo, entrevêem-se um adulto agachado e metade do corpo de um homem em pé. A cena parece se passar numa ponte ou passarela. Trata-se de uma alusão à ditadura brasileira. Não se afirma, como anteriormente na contracapa da edição brochura, que a história se passa "sob a ditadura Vargas em 1954". Pairam a dúvida e a sugestão na utilização do adjetivo "ditador" no trecho "Brasil, 1954. Pouco a pouco abandonado pelo exército... o regime do ditador Getulio Vargas vacila". Além de reforçar o mal-entendido histórico ocorrido na apresentação da edição brochura (como comentado acerca do equívoco da ditadura de Vargas), salienta-se de imediato o anacronismo da ilustração, pois as roupas das pessoas na foto remetem o leitor ao período ditatorial da concepção da obra (repressão dos anos 1960-1970), e não ao período getulista, seja ele da ditadura ou não. 

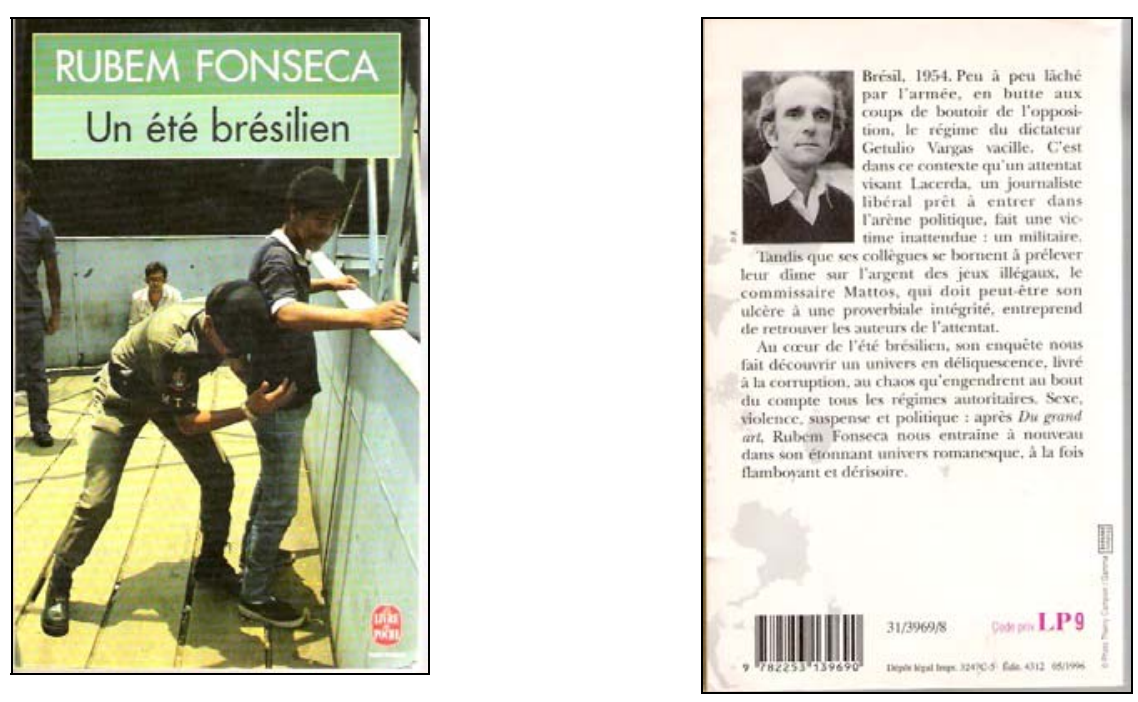

A contracapa traz a mesma foto do autor da edição precedente e o resumo da obra:

Brésil, 1954. Peu à peu lâché par l'armée, en butte aux coups de boutoir de l'opposition, le régime du dictateur Getulio Vargas vacille. C'est dans ce contexte qu'un attentat visant Lacerda, un journaliste libéral prêt à entrer dans l'arène politique, fait une victime innatendu: un militaire.

Tandis que ses collègues se bornent à prélever leur dîme sur l'argent des jeux illégaux, le commissaire Mattos, qui doit peut-être son ulcère à une proverbiale intégrité, entreprend de retrouver les auteurs de l'attentat.

Au coeur de l'été brésilien, son enquête nous fait découvrir um univers en déliquescence, livré à la corruption, au chãos qu'engendrent au bout du compte tous les regimes autoritaires. Sexe, violence, suspense et politique: après Du grand art, Rubem Fonseca nous entraîne à nouveau dans son étonnant univers romanesque, à la fois flamboyant et dérisoire. ${ }^{80}$

Assim como na edição de livro de bolso de Du grand art, notam-se na página 3 dois parágrafos contendo a biografia de Rubem Fonseca. Essas informações não figuravam na edição brochura de Un été brésilien, que

\footnotetext{
80 "Brasil, 1954. Pouco a pouco abandonado pelo Exército, exposto aos golpes violentos da oposição, o regime do ditador Getúlio Vargas vacila. É nesse contexto que um atentado visando Lacerda, um jornalista liberal pronto a entrar na arena política, faz uma vítima inesperada: um militar.

Enquanto seus colegas se limitam a retirar seu dízimo do dinheiro dos jogos ilegais, o comissário Mattos, que deve talvez sua úlcera a uma proverbial integridade, decide encontrar os autores do atentado.

Em pleno verão brasileiro, sua investigação nos faz descobrir um universo de degradação, entregue à corrupção, ao caos que, no fim das contas, todos os regimes autoritários engendram.
} 
apresentava sucintamente a frase "Né en 1925 au Brésil, Rubem Fonseca vit à Rio de Janeiro" no final do texto da contracapa.

O segundo parágrafo do texto lista a produção fonsequiana traduzida pela Grasset e omite a publicação Le cas Morel suivi de Bonne et heureuse année, da editora Flammarion, de 1979, primeira obra publicada na França, mais uma vez informando erroneamente o leitor.

\section{UN ÉTÉ BRÉSILIEN}

Rubem Fonseca est né en 1925 au Brésil. Avocat depuis 1948, il s'est en outre illustré dans le journalisme, l'enseignement et la critique cinématographique.

Depuis 1963, il a publié trois scénarios et plusieurs ouvrages qui ont tous reçu un prix littéraire brésilien. Du grand art, paru chez Grasset en 1986, est le premier livre publié en France, suivi, toujours chez Grasset, de Bufo et Spallanzani (1989), Vastes émotions et pensées imparfaites (1991), et Un été brésilien (1993). Rubem Fonseca est un des plus célèbres auteurs brésiliens contemporains. ${ }^{81}$

Em ambas as edições de bolso, na capa, em baixo à direita, constam o selo "Le livre de poche" e a especificação "texte intégral". Tais particularidades visam fornecer o máximo de informação possível ao leitor/comprador de uma só vez.

A análise do material paratextual selecionado e descrito neste capítulo permite a elaboração de algumas reflexões iniciais e parciais a respeito de projetos editoriais tanto da Flammarion quanto da Grasset. Ao se observar a primeira publicação, considera-se que não há aparente apelo visual aos clichês brasileiros. A capa e a contracapa são bem sóbrias. Explicita-se na contracapa a intenção da editora Flammarion de lançar um autor marcado pela censura,

Sexo, violência, suspense e política: depois de $A$ grande arte, Rubem Fonseca nos arrasta novamente em seu espantoso universo romanesco, ao mesmo tempo brilhante e insignificante.

81 "AGOSTO

Rubem Fonseca nasceu em 1925 no Brasil. Advogado desde 1948, destacou-se também no jornalismo, no magistério e na crítica cinematográfica.

De 1963 até hoje publicou três roteiros e diversas obras que receberam todas, sem exceção um prêmio literário brasileiro. A grande arte, publicado por Grasset en 1986, é o primeiro livro publicado na França, seguido, ainda na Editora Grasset, por Bufo et Spallanzani (1989), Vastas emoções e pensamentos imperfeitos (1991) e Agosto (1933). Rubem Fonseca é um dos mais famosos autores brasileiros contemporâneos." 
portador de uma ideologia, de uma tendência estética social. Selecionaram-se o seu primeiro romance e a então mais recente coletânea de contos. Pode-se vislumbrar a intenção da editora de lançar, em 1979, um autor estrangeiro dentro de um projeto editorial que contemple tanto a questão do gênero (romance policial) quanto a questão política e social.

Em 1986, sete anos após a publicação do primeiro romance de Rubem Fonseca em língua francesa, em nova editora (Grasset Et Fasquelle) e com novo tradutor (Philippe Billé), surge a publicação de $A$ grande arte/Du grand art, segundo romance de Rubem Fonseca, três anos após sua publicação no Brasil. Ao se examinar o conjunto dos lançamentos dessa segunda editora, nota-se que, se projeto editorial há, ele contempla apenas a publicação dos romances de Rubem Fonseca: lançamento de Buffo \& Spallanzani, em 1989 (quatro anos após o lançamento no Brasil), Vastes émotions et pensées imparfaites, em 1990 (dois anos após o lançamento do original no Brasil), Un été brésilien, em 1973 (três anos após sua publicação no Brasil) e Le sauvage de l'opéra, em 1998 (quatro anos após o lançamento no Brasil). Todas as edições da Grasset especificam o gênero "roman" na capa. O projeto editorial não contemplará a produção de contos do autor.

Avalia-se que a publicação de Du grand art alcançou um provável sucesso esperado, pois os dois romances seguintes obtiveram atenção especial em sua edição com dupla capa. Esse fato é reforçado pela publicação posterior de $D u$ grand art em livro de bolso. O mesmo talvez não possa ser dito a respeito de Bufo \& Spallanzani e Vastas emoções e pensamentos imperfeitos. Nenhum dos dois romances recebeu edição em livro de bolso. Já Un été brésilien deve ter repetido o sucesso de público de Du grand art, pois também recebeu edição em livro de bolso posteriormente.

Inscrições como "roman", definindo o gênero do produto, e "Traduit du brésilien", "traduit du portugais (brésilien)" ou "traduit du portugais (Brésil)", determinando sua origem, são elementos importantes na comunicação visual imediata de um leitor potencial. 
Não menos chamativas e reveladoras são as opções gráficas da editora Grasset, que vão desde a utilização de grafismo de Elvira Bach e Philippe Soyez, nos quais sobressai a insinuante, tórrida e sensual cor vermelha, à mescla de elementos do enredo com clichês do exotismo brasileiro, como o Pão de Açúcar ao fundo, o destaque do carnaval, a foto retratando a repressão militar. Extremamente sugestivas, as capas pendem tanto a um apelo exótico quanto a um esforço de associação entre a ilustração e o enredo da obra.

Essas poucas considerações, aliadas às primeiras, resultantes do exame do epitexto, configurado na fortuna crítica do autor na França, buscam, juntamente com as reflexões do próximo capítulo, esclarecer, em conjunto, a imagem, sobretudo literária, que a França veicula do Brasil contemporâneo.

Os quadros que seguem recapitulam e resumem as informações aqui fornecidas.

\section{CAPAS}

\begin{tabular}{|c|c|c|c|c|c|c|c|}
\hline $\begin{array}{l}\text { Título do } \\
\text { livro }\end{array}$ & Autor & $\begin{array}{c}\text { Menção à } \\
\text { língua de } \\
\text { origem }\end{array}$ & $\begin{array}{c}\text { Menção } \\
\text { ao } \\
\text { tradutor }\end{array}$ & $\begin{array}{l}\text { Menção } \\
\text { ao } \\
\text { gênero }\end{array}$ & Editora & Coleção & $\begin{array}{c}\text { Ilustração } \\
\text { ou } \\
\text { foto }\end{array}$ \\
\hline $\begin{array}{l}\text { Le cas } \\
\text { Morel suivi } \\
\text { de Bonne et } \\
\text { heureuse } \\
\text { année }\end{array}$ & $\begin{array}{l}\text { Rubem } \\
\text { Fonseca }\end{array}$ & 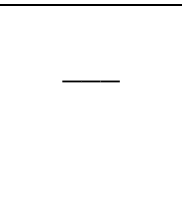 & 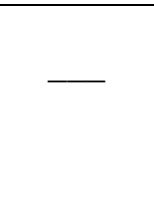 & & Flammarion & $\begin{array}{l}\text { Lettres } \\
\text { étrangères }\end{array}$ & 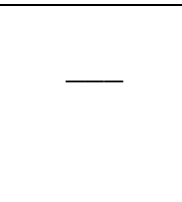 \\
\hline Du grand art & $\begin{array}{l}\text { Rubem } \\
\text { Fonseca }\end{array}$ & $\begin{array}{l}\text { Traduit du } \\
\text { par Phili }\end{array}$ & $\begin{array}{l}\text { brésilien } \\
\text { pe Billé }\end{array}$ & roman & Grasset & & SIM \\
\hline $\begin{array}{l}\text { Buffo \& } \\
\text { Spallanzan } \\
\text { Capa } \\
\text { removível }\end{array}$ & $\begin{array}{l}\text { Rubem } \\
\text { Fonseca }\end{array}$ & 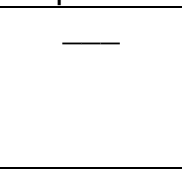 & - & roman & Grasset & & SIM \\
\hline $\begin{array}{l}\text { Buffo \& } \\
\text { Spallanzani } \\
\text { Capa } \\
\text { brochura }\end{array}$ & $\begin{array}{l}\text { Rubem } \\
\text { Fonseca }\end{array}$ & $\begin{array}{l}\text { Traduit di } \\
\text { par Phili }\end{array}$ & $\begin{array}{l}\text { brésilien } \\
\text { pe Billé }\end{array}$ & roman & Grasset & & 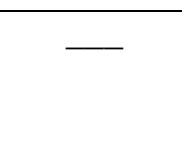 \\
\hline $\begin{array}{l}\text { Vastes } \\
\text { émotions et } \\
\text { pensées } \\
\text { imparfaites } \\
\text { Capa }\end{array}$ & $\begin{array}{l}\text { Rubem } \\
\text { Fonseca }\end{array}$ & $\bar{L}$ & 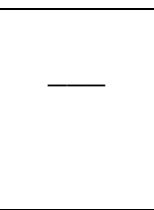 & roman & Grasset & & SIM \\
\hline
\end{tabular}




\begin{tabular}{|c|c|c|c|c|c|c|c|}
\hline removível & & & & & & & \\
\hline $\begin{array}{l}\text { Vastes } \\
\text { émotions et } \\
\text { pensées } \\
\text { imparfaites } \\
\text { Capa } \\
\text { brochura }\end{array}$ & \begin{tabular}{|l|} 
Rubem \\
Fonseca
\end{tabular} & $\begin{array}{r}\text { Tradui } \\
\text { par } P\end{array}$ & $\begin{array}{l}\text { ésilien } \\
\text { Billé }\end{array}$ & roman & Grasset & & 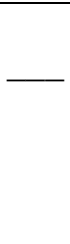 \\
\hline $\begin{array}{l}\text { Un été } \\
\text { brésilien }\end{array}$ & $\begin{array}{l}\text { Rubem } \\
\text { Fonseca }\end{array}$ & 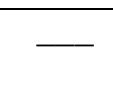 & 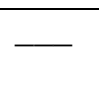 & roman & Grasset & & SIM \\
\hline $\begin{array}{l}\text { Le sauvage } \\
\text { de l'opéra }\end{array}$ & $\begin{array}{l}\text { Rubem } \\
\text { Fonseca }\end{array}$ & 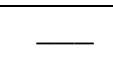 & 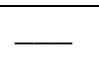 & roman & Grasset & & SIM \\
\hline Du grand art & $\begin{array}{l}\text { Rubem } \\
\text { Fonseca }\end{array}$ & 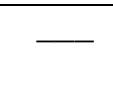 & 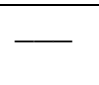 & & & $\begin{array}{l}\text { Livre de } \\
\text { poche }\end{array}$ & SIM \\
\hline $\begin{array}{l}\text { Un été } \\
\text { brésilien }\end{array}$ & $\begin{array}{l}\text { Rubem } \\
\text { Fonseca }\end{array}$ & - & 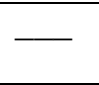 & & & $\begin{array}{l}\text { Livre de } \\
\text { poche }\end{array}$ & SIM \\
\hline
\end{tabular}

CONTRACAPAS

\begin{tabular}{|c|c|c|c|c|c|c|}
\hline Título do livro & Autor & $\begin{array}{c}\text { Menção } \\
\text { à língua } \\
\text { de } \\
\text { origem }\end{array}$ & $\begin{array}{l}\text { Menção } \\
\text { ao } \\
\text { tradutor }\end{array}$ & TEXTO & $\begin{array}{c}\text { Ilustração } \\
\text { ou } \\
\text { foto }\end{array}$ & $\begin{array}{l}\text { Créditos } \\
\text { Ilustrador } \\
\text { Agência }\end{array}$ \\
\hline $\begin{array}{l}\text { Le cas Morel suivi de } \\
\text { Bonne et heureuse } \\
\text { année }\end{array}$ & $\begin{array}{l}\text { Rubem } \\
\text { Fonseca }\end{array}$ & \multicolumn{2}{|c|}{$\begin{array}{l}\text { Traduit du brésilien } \\
\text { par Marguerite } \\
\text { Wünscher }\end{array}$} & SIM & & - \\
\hline Du grand art & & & & SIM & 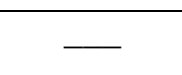 & - \\
\hline $\begin{array}{l}\text { Buffo \& Spallanzan } \\
\text { Capa removível }\end{array}$ & & $\begin{array}{l}\text { Traduit d } \\
\text { par Phil }\end{array}$ & $\begin{array}{l}\text { brésilien } \\
\text { pe Billé }\end{array}$ & SIM & 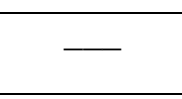 & \\
\hline $\begin{array}{l}\text { Buffo \& Spallanzani } \\
\text { Capa brochura }\end{array}$ & & & & SIM & 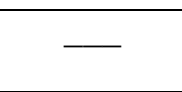 & \\
\hline $\begin{array}{l}\text { Vastes émotions et } \\
\text { pensées imparfaites } \\
\text { Capa removível }\end{array}$ & & $\begin{array}{l}\text { Traduit d } \\
\text { (brésil } \\
\text { Philip }\end{array}$ & $\begin{array}{l}\text { portugais } \\
\text { en) par } \\
\text { e Billé }\end{array}$ & SIM & & SIM \\
\hline $\begin{array}{l}\text { Vastes émotions et } \\
\text { pensées imparfaites } \\
\text { Capa brochura }\end{array}$ & & & & SIM & - & - \\
\hline Un été brésilien & & $\begin{array}{r}\text { Traduit d } \\
\text { (Brésil) p } \\
\text { B }\end{array}$ & $\begin{array}{l}\text { portugais } \\
\text { r Philippe } \\
\text { lé }\end{array}$ & SIM & & - \\
\hline Le sauvage de l'opéra & & $\begin{array}{r}\text { Traduit d } \\
\text { (Brésil) p } \\
B\end{array}$ & $\begin{array}{l}\text { portugais } \\
\text { r Philippe } \\
\text { lé }\end{array}$ & SIM & & \\
\hline Du grand art & $\begin{array}{l}\text { Rubem } \\
\text { Fonseca }\end{array}$ & $\bar{L}$ & ב & SIM & $\begin{array}{l}\text { Livre de } \\
\text { poche }\end{array}$ & \\
\hline Un été brésilien & Rubem & & & SIM & Livre de & \\
\hline
\end{tabular}




\section{III \\ Alguns livros por dentro}

O presente capítulo é consagrado à análise de textos de Rubem Fonseca mediante cotejo do texto original em português e sua tradução para a língua francesa. A evolução do estudo e o progressivo acesso ao material tanto textual quanto paratextual definiram sua configuração: três corpus homogêneos são objeto de três distintas abordagens que permitem a verificação de marcas culturais e sociais reveladoras de tendências domesticadoras (assimiladoras) ou estrangeirizadoras nas traduções. Observam-se inicialmente os primeiros textos publicados em livro com tradução de Marguerite Wünscher. O exame dos contos orientou as primeiras análises para as marcas culturais presentes na oralidade literária e, sobretudo, no vocabulário gírio e chulo. Quatro contos são destacados em Feliz ano novo por apresentarem esse tipo de vocabulário com maior freqüência, representando assim um recorte específico. A análise de $O$ caso Morel complementa esse primeiro bloco. 
O segundo bloco traz os contos traduzidos constantes em coletâneas e antologias. Em razão da temática mais universalizante desses contos, um segundo enfoque é dado à observação desse material. Amplia-se a questão das marcas culturais para privilegiar uma sondagem de teor mais geral. Não se desprezam, entretanto, o cotejo e a análise quando convenientes.

Os romances traduzidos por Philippe Billé constituem o corpus do terceiro bloco, à luz da correspondência trocada entre Rubem Fonseca e seu tradutor francês. Optou-se pela descrição do material em questão e pela análise parcial de dois documentos de relevância que trazem à baila soluções apresentadas por Rubem Fonseca a partir dos questionamentos de Philippe Billé.

Além do destaque dado às marcas culturais verificado em algumas opções dos tradutores, as três abordagens permitem a reflexão acerca dos projetos editorias da publicação dos textos.

\section{As marcas sociais e culturais nas traduções da pioneira Marguerite Wünscher}

\section{Feliz ano novo I Bonne et heureuse année}

O levantamento e a análise de alguns elementos de natureza lingüística presentes na fala-narrativa em quatro contos de Feliz ano novo fornecem elementos para a verificação de algumas soluções adotadas por Marguerite Wünscher, a primeira tradutora do autor brasileiro, em sua tradução Bonne et heureuse année. Decidiu-se efetuar um recorte nos contos, à guisa de amostragem, e o critério de seleção recaiu sobre a fala e expressão de personagens das classes mais desfavorecidas, a ralé. ${ }^{82}$ Dessa forma, dentre os contos que apresentam essas características, foram selecionados "Feliz ano novo", "Abril, no Rio, em 1970", "Botando pra quebrar" e "Dia dos namorados". Para melhor se apreciar alguns aspectos da tradução dos textos, a proposta inicial 
é abordar alguns elementos de ordem teórica, enfatizando os componentes do discurso e o vocabulário gírio. Em seguida, serão selecionados elementos de ordem cultural e social, buscando verificar igualmente as opções e soluções da tradutora francesa, sem, no entanto, se esgotarem as possibilidades de análise desse corpus.

Vale salientar que a aparente "displicência" do fluxo narrativo, em Rubem Fonseca, acentua a linguagem popular; o uso de gíria e palavrões auxilia na construção da identidade de suas personagens. Para o tradutor, compreender esse mecanismo no texto-fonte é compreender parte da essência do material a ser traduzido, pois essas são igualmente marcas sociais.

Nos quatro contos inicialmente selecionados, os personagens-narradores apresentam, além dessas características, outros pontos em comum a partir da oralidade. São relatos na primeira pessoa, pequenas histórias retiradas da vida dos narradores e contadas detalhadamente. O leitor é interpelado como um ouvinte cúmplice, testemunha das agruras dos narradores (sabem-se os nomes dos narradores de "Abril, no Rio, em 1970", Zé, e de "Dia dos namorados", Paulo/Mandrake. Dos outros dois contos, ignoram-se os nomes dos narradores). O leitor é, então, convidado, de forma sutil e nunca declarada, a compartilhar um fato que se destaca na vida do contador da história. É possível imaginar os narradores-personagens, contando uma história, tanto num bar, batendo um papo, como numa delegacia, dando um depoimento. São histórias narradas no passado, com certo toque de testemunho pessoal. Todas as histórias envolvem o narrador e um acontecimento. Em "Feliz ano novo", um assalto; em "Abril, no Rio, em 1970", uma partida de futebol; em "Botando pra quebrar", uma pancadaria numa boate; e em "Dia dos namorados", um caso de chantagem de um travesti. No decorrer do relato, o leitor é colocado a par do contexto geral da vida miserável dos narradores sem, no entanto, desviar-se do acontecimento narrado. Nos quatro contos prima o mesmo tipo de narração, combinando-se os diversos tipos de discurso.

${ }^{82}$ Embora seja importante ressaltar que o palavreado chulo não é privilégio das classes mais baixas, em Rubem Fonseca. Trata-se aqui apenas de um recorte prático para efeitos de amostragem. 
Outro aspecto a ser destacado é que os contos caracterizam-se pelo emprego da linguagem coloquial, falada, recheada de gírias e palavrões. A linguagem, por vezes, é tão chocante quanto os atos relatados pelos personagens-narradores. O emprego de vocábulos de baixo calão sempre esteve ligado às camadas mais baixas da população, ou seja, as mais pobres. Válvula de escape, desabafo, compensação, o "palavrão" serve, por um lado, para chocar, exagerar, exteriorizar sentimentos extremos do falante, por outro, constitui-se em linguagem própria a um universo coloquial, podendo ter até mesmo conotação afetiva, atestando que o signo é "uma arena de conflitos" (Bakhtin, 1981).

Hoje vivemos no Brasil uma época desmistificadora do "palavrão" que, tendo "virado moda" a partir dos anos 1960, encontrou barreira na censura do regime militar, o que apenas serviu para atiçar os ânimos dos jovens e escritores, pois, segundo Preti (1995, p.14), "foi na década de 60 que os palavrões começaram a pulular nas peças de teatro, causando grande escândalo".

O "vocabulário gírio, com seu humor, sua ironia, seu poder agressivo (quando não injurioso), cumpre também um papel de um verdadeiro processo de catarse, de purgação para o homem moderno, que nele encontra uma das formas de defender-se das injustiças sociais, atacando-as, para compensar sua revolta e frustração" (Preti, 1996, p.143). Não é difícil imaginar a reação do público quando da publicação do conto. Se os primeiros personagens de Rubem Fonseca primavam pela solidão e introspecção, em 1975 eles chocam pelo que fazem e pelo modo como se expressam, revelando o grau de revolta e insatisfação popular do personagem-narrador, do autor e do leitor.

Nesse sentido, vale relembrar a epígrafe francesa de Feliz no novo, um trecho do poema de François Villon (2000), a qual interage com os contos em dois níveis.

XVIII

O imperador condescendeu:

L'empereur si l'araisonna:

"Pour quoi es tu larron de mer?"

"Por que és um ladrão do mar?"

Eis a resposta que the deu:

"E por que ladrão me chamar? 
L'autre responce luy donna:

"Pour quoi larron me faiz nommer?

Pour ce qu'on me voit escumer

En une petiote fuste?

Se comme toy me peusse armer, Comme toy empereur je feusse.

Mais que veulx-tu? De ma fortune, Contre qui ne puis bonnement, Qui si faulcement me fortune, Me vient tout ce gouvernement. Excuse moy aucunement. Et saiche qu'en grant povreté, (Ce mot se dit communement) Ne gist pas grande loyauté."
Porque se me vê a escumar

Nesse barco de ninharia?

Se também pudesse me armar

Eu mesmo imperador seria.

XIX

"Mas que queres, minha fortuna, Sobre a qual nem sequer comento, E que pérfida me infortuna, Causou-me tal desregramento. Perdoa: tens discernimento, $E$ vês que na necessidade - Tal se diz a todo momento Não há como ter lealdade."

Em um primeiro nível, pelo seu conteúdo, no qual um imperador dialoga com um indivíduo tratando-o como um marginal (e, em seguida, mudando seu destino, o que não acontece em Rubem Fonseca). Em um segundo nível, pelo fato de ter sido François Villon (1431-1463?) um dos primeiros a empregar a gíria, o argot, na literatura, no século XV, na França, em seus poemas populares, remetendo à linguagem de marginais e mascates, caracterizando a gíria como uma linguagem de grupos restritos. Conforme Preti (1996, p.143):

Algumas das características mais típicas da gíria se identificam plenamente com o pensamento popular, constituindo a representação lingüística do desprezo pelas tradições, pela moral vigente, pelas desigualdades sociais, pelo poder. A gíria pode ser considerada um reflexo, um certo "mecanismo de defesa social" das classes marginalizadas ou menos favorecidas. A ousadia de suas metáforas e metonímias; a intensidade de suas hipérboles; os processos morfológicos de deformação de significantes, pela eliminação de sílabas ou acréscimo de sufixos pouco comuns constituem a marca de um vocabulário que, agredindo a tradição lingüística, agride também a sociedade que ela representa.

A gíria, ainda segundo Preti (1996, p.139-40), como fenômeno tipicamente sociolingüístico, pode ser estudada de duas perspectivas: a gíria de grupo, pertencente a grupos sociais restritos, como se fosse um código apenas para iniciados, e a gíria comum, que é a primeira popularizada, que perde sua identificação inicial. Daí a grande efemeridade da gíria. Portanto, se alguns vocábulos empregados no texto pertenciam, nos anos 1970, a uma gíria de grupo, 
hoje são considerados gíria comum, de "domínio público". Certas palavras que não tinham na época prestígio social, e eram classificadas como obscenas, passam pouco a pouco a freqüentar as conversações como vocábulos comuns, por vezes até com carga afetiva. Outras perderam sua força nos anos 1980-1990, como bacana, que volta hoje a ser utilizada pelos jovens.

\section{"Feliz ano novo"I "Bonne et heureuse année"}

Em "Feliz ano novo", o narrador, do qual não se conhece o nome, como já salientado, é um dos três indivíduos, marginais (os outros são Pereba e Zequinha), que invadem uma casa situada em um bairro refinado do Rio de Janeiro durante a festa de réveillon de ano novo. Eles roubam, matam e vão embora. O narrador contará em detalhes o que ocorreu antes, durante e depois do roubo. Estrutura-se o conto, pois, em três partes narradas/contadas de forma cronológica: antes, durante e depois do assalto.

Ao dar voz ao personagem/marginal, ao não utilizar as marcas gráficas tradicionais empregadas no discurso direto e ao introduzir o discurso indireto livre, o autor provoca uma série de efeitos ambíguos que revelam a fatura dos textos literários na construção do ambiente e de seus personagens. Convém apontar aqui algumas dessas passagens.

O primeiro parágrafo situa a história e o leitor temporalmente: é o final do ano. De imediato, situa igualmente o personagem-narrador como uma "testemunha" pela utilização do verbo VER e da primeira pessoa. Trata-se de um observador e não participante do consumo de final de ano. Até então, pode-se deduzir a não-participação do personagem quanto ao fato observado, porém não demora muito para se verificar a sua total exclusão. Como o segundo parágrafo mostra o emprego do discurso direto sem marcas, poderíamos nos questionar quanto à categorização do primeiro parágrafo. O questionamento poderia ser

relevante: com quem está falando o personagem-narrador quando começa a narração: com o leitor ou com Pereba desde o início? Desse ponto de vista, 
indícios de que se trata de uma narração no primeiro parágrafo são os verbos; outro indício seria a própria mudança de parágrafo, indicando a passagem de uma narração simples para o discurso direto, do segundo parágrafo. A paragrafação deve ser considerada, conseqüentemente, como uma marcação importante no rodízio das falas e dos tipos de discurso.

Outro elemento a ser levado em conta é que se trata de um texto literário. Apesar de apresentar a manifesta vontade do autor em reproduzir a fala na escrita literária por meio de um registro popular de língua, os trechos narrativizados diferenciam-se dos discursos diretos por um sutil refinamento: estavam vendendo em vez de tavam vendendo, por exemplo, que seria mais condizente com o discurso direto, como se pode observar em "Ela tava nua, disse Pereba" (§24).

Ao cotejar o texto em português de Rubem Fonseca e a tradução francesa de Marguerite Wünscher, constata-se de imediato a manutenção do tipo de discurso característico ao conto. Há, no entanto, certa "subversão" na paragrafação. O parágrafo 11 do texto em francês engloba os parágrafos 11 e 12 do original, enquanto os parágrafos 13 e 14 da tradução constituem um único parágrafo no texto original: o 14. O parágrafo 104 em português foi igualmente desmembrado na tradução francesa.

Por que teria ocorrido a união dos trechos 11 e 12 em um só parágrafo e o desmembramento do parágrafo 14 brasileiro em dois parágrafos na versão francesa? ${ }^{83}$ Pode ter sido falta de atenção ou uma opção da tradutora, e nesse caso convém observar sua adequação ou inadequação. No primeiro caso, podese observar que a mudança de parágrafo implica a mudança de assunto, em consonância com as opções do escritor. Não há motivo aparente para que esses parágrafos sejam reunidos.

\section{Português}

\footnotetext{
${ }^{83}$ Foram consultadas duas edições no original brasileiro. É possível ainda que o original da tradutora apresentasse outra paragrafação.
} 
Pereba sempre foi supersticioso. Eu não. Pereba a toujours été superstitieux. Moi, Tenho ginásio, sei ler, escrever e fazer raiz non. J'ai mon brevet, je sais lire, écrire et quadrada. Chuto a macumba que quiser. extraire les racines carrées J'en ai rien à foutre de la macumba. On a allumé un joint et regardé le feuilleton. De la merde, on a changé de chaîne, pour tomber sur un western. Encore une cochonnerie.

Ascendemos uns baseados e ficamos vendo a novela. Merda. Mudamos de canal, prum bangue-bangue. Outra bosta.

\section{Quanto ao segundo caso,}

\section{Português}

Pena que não tão dando pra gente, disse Pereba. Ele falava devagar, gozador, cansado, doente.

\section{Francês}

Dommage que ce ne soit pas avec nous, a dit Pereba.

Il parlait lentement, d'un ton ironique, fatigue, malade.

Com freqüência o narrador se manifesta na ocasião de um discurso direto, fornecendo detalhes que se referem a essa fala. É o que ocorre nesse parágrafo, no qual o desmembramento afasta o comentário do narrador da fala específica. Também aqui, não há motivo aparente para essa modificação. O mesmo ocorre com o terceiro caso de desmembramento:

\section{Português}

Inocêncio, você já acabou de comer? Me traz uma perna de peru dessas aí. Em cima da mesa tinha comida que dava para alimentar o presídio inteiro. Comi a perna de peru. Apanhei a carabina doze e carreguei os dois canos

\section{Francês}

Inocencio, tu as fini de manger ? Amènemoi une de ces cuisses de dinde, lá.

Sur la table, il y avait assez de victuailles pour rassasier une prison entière. J'ai mangé la cuisse de dinde. J'ai pris la carabine douze et j'ai chargé les deux canons. 
Outro momento a ser destacado reside na coordenação do segundo parágrafo. Em:

Pereba, vou ter que esperar o dia raiar e apanhar cachaça, galinha morta e farofa dos macumbeiros.

Trata-se de uma coordenação sintática, porém não semântica, ou seja, o que parece um período coordenado revela-se semanticamente uma subordinação final. A conjunção "e" nessa ocorrência tem valor de "para": "vou ter que esperar o dia raiar para apanhar cachaça, galinha morta e farofa dos macumbeiros".

A tradução francesa apresenta uma curiosidade: "Pereba, il va falloir que j'attende le jour se lève et prendre de la cachaça, une poule morte et de la farofa de macumbeiros". Mesmo que a tradutora tenha interpretado como uma coordenação sintática e semântica, o resultado não parece o mais natural, já que o verbo "prendre" encontra-se no infinitivo, coordenado ao verbo "attendre", no subjuntivo. Além disso, numa consulta preliminar a gramáticas de usos da língua francesa, verifica-se que a conjunção "et" parece não desempenhar o papel de conectivo de finalidade, como em português.

Mais um trecho merece atenção especial:

Ele tá querendo comer restos de lemanjá, disse Pereba.

Brincadeira, eu disse. Afinal, eu e Zequinha tínhamos assaltado um supermercado no Leblon, não tinha dado muita grana, mas passamos um tempão em São Paulo na boca do lixo, bebendo e comendo as mulheres. A gente se respeitava.

A expressão, "brincadeira", em português equivale, nesse contexto, a "eu estou/estava brincando", pois foi o narrador que anteriormente sugeriu que comessem os restos de lemanjá. O valor pragmático da expressão parece não ter sido captado pela tradutora, pois observa-se, em francês, a troca do sujeito no ato conversacional:

II veut manger les restes de lemanjá, a dit Pereba.

II blague, que j'ai dit. Pour finir, Zequinha et moi, on a fait un casse dans un supermarché de Leblon, ça ne nous pas rapporté beaucoup de fric, mais on est reste pas mal de temps à São Paulo, dans la zone, à boire et à se taper des femmes. C'était la belle vie. 
Quanto às opções morfossintáticas, toma-se como exemplo a seguinte passagem:

Fumamos. Esvaziamos uma pitu.

traduzido por:

Cigarettes. Une bouteille de vidé.

Em nenhum momento fica claro, no original, que os personagens fumavam cigarros. O fato de o autor utilizar a forma verbal deixa justamente pairar a ambigüidade do que os personagens estão consumindo: cigarros ou maconha?

Quanto aos termos relativos ao ato sexual, esses têm seus correspondentes, mas são por vezes amenizados, mudando até mesmo do registro popular para o mais refinado, da norma culta, como quando estão falando de um outro companheiro, o Lambreta, e sua preferência por homens:

É mas dizem que ele dá o bozó, disse Zequinha.

Ouais, mais il paraît qu'il se fait sodomiser, a dit Zequinha.

Evidentemente, a expressão "se faire enculer", muito mais forte, aparece mais à frente.

Se, por um lado, o trecho citado nos parece "mais leve" do que o original, por outro, outro segmento ganhará na tradução.

Antes de saírem da casa chique, o narrador pergunta ao companheiro: "Não vais comer uma destas?". O primeiro declina, mas o segundo responde: "Acho que vou papar aquela moreninha". Em francês: "Tu ne vas pas te taper une de ces beautés ?... Je crois que je vais tirer un coup avec cette petite brune“.

Se, por um lado, "se taper" corresponde bem ao campo semântico conotativo da alimentação, em relação ao sexo, por outro, há perda do jogo paralelístico de "comer" e "papar", muito específico à língua portuguesa, e um novo par paralelo se instala: 
A garota tentou atrapalhar, mas Zequinha deu uns murros nos cornos dela, ela sossegou e ficou quieta, de olhos abertos, olhando para o teto, enquanto era executada no sofá.

em francês:

La fille a essayé de résister, mais Zequinha lui a flanqué une raclée, elle s'est clamée et est restée tranquille, les yeux grands ouverts, regardant le plafond pendant qu'elle était exécutée sur le sofa.

Além de manter a relação com o "executar" do original, de conotação sexual, cria-se o diálogo na língua francesa com a expressão "tirer un coup". Ambas podem ter significado próprio: atirar / executar = matar, como conotação sexual.

Esse é um bom exemplo de como a língua-alvo, com seu potencial, suas próprias imagens, pode enriquecer o original. Sabe-se, no entanto, que nem sempre é o caso, e muitas vezes expressões características são enfraquecidas pela falta de equivalência. É o que ocorre com a expressão "uma Thompson lata de goiabada", tantas vezes usada no texto. Em francês, utilizou-se "vieille Thompson" ou "vieille mitrailleuse", uma escolha facilitadora para a compreensão do leitor francês.

Vale mencionar outro recurso que visa esclarecer esse leitor. A tradutora optou pela manutenção em português de termos como "cachaça", "farofa de macumbeiros" e "babalaôs", explicitando a significação em nota de rodapé. O mesmo ocorreu com o nome "lemanjá". No entanto, a compreensão de outros nomes próprios que indicam localidades ficaram implícitos e a dedução ficou a cargo dos leitores: (hospital) Miguel Couto, (rio) Guandu. O contexto mostra que se ônus houve para o leitor, foi mínimo. A inserção de notas de rodapé em uma tradução corta o fluxo de leitura, pois se trata de um outro plano de discurso. Abusar desse recurso seria contrariar as opções do próprio escritor.

Até esse ponto, algumas expressões foram elencadas que, bem ou mal, correspondem ao texto original. Outras expressões, entretanto, marcadamente 
sociolingüísticas, destacam-se, comprometendo por vezes o aspecto social presente no original.

$\mathrm{Na}$ frase "já viu como as branquelas dançam?", temos subentendido um elemento social de suma importância na utilização do termo "branquelas". A parte da população brasileira mais pobre e marginalizada não são os brancos e provavelmente nossos personagens são mulatos ou negros, em contraposição às "branquelas". Em francês, temos "tu as vu comment elles dansent ces connasses?". Na passagem de "branquelas" para "connasses" (um xingamento bastante forte em francês), perde-se o aspecto social. Uma possível solução que mantivesse pelo menos parte do sentido de "branquela" seria a utilização de "pâlichonne", ainda que de uma pesquisa mais profunda pudesse surgir outro termo mais adequado.

Já a expressão "é um assalto" surge no conto quando os três pivetes adentram uma mansão onde ocorre a festa de ano novo, na intenção de roubar todos os convidados:

É um assalto, gritei bem alto, para abafar o som da vitrola.

Essa expressão, tão conhecida entre os brasileiros, será traduzida por Marguerite Wünscher como "c'est un cambriolage". "Cambriolage" aparece no dicionário Larousse como: "action de cambrioler", ou seja, originário do provençal cambro, que significa chambre, e equivale a "dévaliser (une maison, un appartement) par effraction, escalade, etc." Ou seja, cambrioler é o furto, sem a presença de vítimas ou, até mesmo, testemunhas. Para o francês, dificilmente há o roubo corpo a corpo, tal como ocorre no conto, não havendo hoje vocábulo que dê conta do que para o brasileiro é o "assalto". O termo "assaut", hoje mais utilizado de forma metafórica, também evidencia a surpresa de um ataque, mas não corresponde ao "assalto" brasileiro, além de não ser utilizado em discurso direto (expressão: "prendre d'assaut"). A língua francesa por vezes recorre até mesmo ao léxico inglês, utilizando a expressão "hold up" em casos de roubo na presença de várias pessoas e, de preferência, em um lugar público. Por sua vez, "Haut les mains" é ligeiramente arcaico (o nosso conhecido "mãos ao alto"). Em 
geral, opta-se por combinar essas duas últimas expressões: "Haut les mains, c'est un hold up!" - quando um grupo invade um lugar público para cometer um assalto.

\section{"Abril, no Rio, em 1970" I "Avril, Rio, 1970"}

Esse conto tem seu início com a sugestão de continuação de um batepapo:

Tudo começou quando o cara que sentou perto de mim na grama disse, olha só o cuspe do Gérson.

O narrador-personagem, Zé, intercala, inicialmente, detalhes de uma partida de futebol que presenciou, dois dias antes de um jogo no qual haverá um olheiro, o treinador do Madureira, Jair da Rosa Pinto, com elementos de sua vida pessoal com sua namorada. Dessa forma, os leitores acabam por conhecer e simpatizar com o Zé. Finalmente, chega o dia da partida e Zé conta também com detalhes o vexame de seu time, que perde, expressando sua decepção. Para os amantes de futebol, o conto mistura elementos reais à ficção. Jair da Rosa Santos realmente foi jogador, treinador do Madureira e seu apelido era Jajá da Barra Mansa. Zé presencia um treino da seleção de 1970 e se impressiona com os comentários de um outro espectador, Braguinha (houve realmente um jogador no Botafogo de nome Braguinha, seria ele? Ou seria o compositor Braguinha, também aficionado do futebol?), sobre o cuspe dos jogadores. A qualidade da saliva no cuspe dos jogadores seria um sinal de qualidade de jogo. Ao conversar com Braguinha, Zé procurava se enturmar, pois estava ali de "penetra":

O cara se chamava Braguinha. Olha o cuspe do Gérson, ele disse, no segundo tempo do treino. Braguinha tinha chegado no intervalo, todo mundo conhecia ele; diziam, ô Braguinha que que você está achando? E ele respondia, vamos estraçalhar os gringos. Eu balançava a cabeça e ria pra ele, concordando. Estava querendo me enturmar, eu era penetra e não queria ser posto para fora, era só olhar para mim que os caras viam que o meu lugar era outro, nem como repórter eu podia passar. 
Assim como se observa em "Feliz ano novo", há aqui na tradução um malentendido quanto ao sujeito de uma oração: "Estava querendo me enturmar". Pode parecer evidente para o leitor brasileiro - e surpreende que a tradutora tenha optado por colocar o Braguinha como sujeito de "se enturmar", reflexivo. Esse tipo de engano ocorre em razão do paralelismo de formas da conjugação da primeira e da terceira pessoa do singular na língua portuguesa: eu estava / ele estava; no entanto, o contexto e a regência verbal são esclarecedores. Além disso, a tradutora utilizou, incompreensivelmente, uma conjunção adversativa (mais), quando deveria ter utilizado uma consecutiva ou aditiva com função consecutiva (et):

II voulait me mettre dans le coup, mais moi j'avais resquillé et je ne voulais pas être mis en dehors, il n'y avait qu'à me regarder pour voir que ce n'était pas ma place, je ne pouvais même pas passer pour un journaliste.

Outra informação que Braguinha dá a Zé é que jogador não sai com mulher antes de jogo:

O Braguinha me contou que eles treinavam todos os dias e não viam mulher, nem as próprias; não tem nada de Rose não, Jairzinho não bota o pé na Mangueira, o Paulo César não passa na porta do Lebatô, os caras estão levando o negócio a sério. Mulher, nem a mãe.

Rose era a esposa de Pelé, Jairzinho era mangueirense e Paulo César Caju era um boêmio incorrigível, daí a menção à casa noturna carioca Lebatô. E aqui está um dos primeiros mal-entendidos na tradução desse conto:

Braguinha m'a dit qu'ils s'entraînaient tous les jours et qu'ils ne voyaient pas de femmes, même pas la leur ; pas question de Rose, ça non, Jairzinho ne met pas le nez dans le quartier de Mangueira, Paulo César ne sort pas de Lebaton, ils font ça sérieusement. Ni femme, ni mère.

A tradutora, não compreendendo que se tratava de um local, pensou tratarse de uma marca de carro: o Lebaton. 
Outro elemento a ser observado é a troca de uma preposição no parágrafo 23, que muda o sentido do que o narrador fez sua namorada "com" (com sentido sexual), para o que ele fez "por" ela:

\section{Português}

Fui, chateado. Cheguei na pensão, deitei, fiquei um tempo enorme curtindo o esporro que ela me tinha dado. Não me incomodava de ser chamado de mentiroso, nem de frouxo, ora bolas, depois de tudo que eu fiz com ela tinha graça ser chamado de frouxo, duvido que ela arranjasse outro com mais disposição do que eu, mas ser chamado de ignorante, pé rapado, isso doeu.
Francês

Je suis parti, très embêté. Arrivé à la pension, je me suis couché, et suis resté longtemps à repenser au savon qu'elle m'avait passé. Ça ne me gênait pas d'être traité de menteur ou de lâche, zut alors! Après tout ce que j'avais fait pour elle, c'était, c'était plutôt drôle d'^tre traité de lâche, cela m'aurait étonné qu'elle en trouve un mieux que moi, mais qu'elle me traite d'ignorant, de fauché, ça m'a fait mal.

No parágrafo 24 , houve um desmembramento inexplicável de parágrafo na tradução:

\section{Português}


Fiquei um tempo enorme acordado, sem poder imaginar coisas boas, pensando na chance, mas sem conseguir imaginar a coisa acontecendo, as jogadas sensacionais, o povo gritando gol. Se me chamassem eu treinava em qualquer time, do Rio, Belo Horizonte, topava o interior de São Paulo, Bahia, qualquer lugar; eu queria uma chance. A única vez que treinei num time profissional foi no São Cristóvão num dia de chuva, o campo estava um lamaçal. Quem já viu apoiador render na lama? Joguei dez minutos, dez minutos, tinha um monte de sujeitos esperando a vez na fila, só pro meio campo, todos na mesma aflição que eu. Depois do treino eu falei com o homem se ele queria que eu voltasse e ele disse calmamente, não, obrigado, sem se incomodar com o meu sofrimento, cagando pra mim.
J'ai mis un temps fou à m'endormir, sans réussir à m'imaginer ce qui m'arriverait de bom, j'essayais de penser que la chance me sourirait un jour, de me répresenter les attaques sensationnelles, et la foule qui crierait : but. Si on m'acceptait, je m'entraînerais dans n'importe quelle équipe de Rio, ed Belo horizonte, je ne refuserais pas d'aller au fin fond de l'État de São Paulo, à Bahia, n'importe où ; je voulais avoir ma chance. La seule fois où j'ai joué dans une équipe professionnelle, c'était au São Cristovão, un jour de pluie, le terrain était un vrai bourbier. Vous avez déjà vu en défenseur bien jouer dans la boue? J'ai joué dix minutes, dix minutes eulement, il y avait une foule de gars qui attendaient dans la queue, uniquement pour faire un essai de milieu de terrain, tous dans le même pétrin que moi.

Après l'entraînement, j'ai demandé au type s'il voulait que je revienne et il a répondu calmement, non merci, sans s'inquiéter de ce que j'éprouvais, il se foutait pas mal de moi.

A omissão de pequenos ou grandes textos também surge como solução para o tradutor, como ocorre no parágrafo 26 :

\section{Português}

Olha, quando você for, o Tiago fica, Gabiru vem buscar o jogo, ajudar o meio campo. Outra coisa, cuidado com o ponta de lança deles, o tal de Jeová. Se for preciso, cacete nele.

\section{Francês}

Bon, écoute-moi, quand tu pars en avant, Tiago reste en arrière, Gabiru vient chercher la balle. Autre chose, attention à leur avantcentre, un certain Jeova. Au besoin, il faut lui taper dessus.

\section{"Botando pra quebrar"I "Comment on devient casseur"}


O título desse conto merece de imediato um comentário. A expressão gíria "botar pra quebrar" tem conotação positiva e significa "fazer as coisas acontecerem", "agitar". No entanto, percebe-se, ao ler o conto, que ela é empregada em seu sentido denotativo, de "por abaixo", "destruir". O personagemnarrador, cujo nome não é conhecido, contará ao leitor um episódio de sua vida de duração aproximada de um dia, contextualizando-o. Durante esse dia, ocorrem diversos fatos humilhantes que o personagem vai reprimindo, até explodir. O leitor vai pouco a pouco conhecendo então o passado desse ex-presidiário e suas dificuldades para encontrar um emprego e manter o relacionamento com Mariazinha, com quem vive. Essa pede-Ihe permissão para se casar com outro homem que possa sustentá-la, e ele consente. Nesse mesmo dia, ele encontra um emprego de leão-de-chácara numa boate e, desgostoso da vida, depois de alguns conflitos, resolve provocar uma grande briga e acaba "botando pra quebrar", no sentido literal da expressão, a boate.

Não se pode dizer que haja "perda" na tradução do título ("Botando pra quebrar" > "Comment on devient casseur"), pois um "casseur" em francês é, dentre outras acepções, um depredador. Perde, no entanto, no jogo de palavras. Outra acepção em francês, mais popular, seria a de um arrombador, o que conduz a um jogo equivocado.

$\mathrm{Na}$ tradução, houve incorporação do parágrafo 7 ao 6 , dessa vez, sem maior ônus para a totalidade desse texto curto (no total, oito parágrafos no original, e sete na tradução).

Observa-se, mais uma vez, um mal-entendido relativo ao sujeito de uma oração quando o patrão vem pedir explicações ao leão-de-chácara por ele ter barrado a entrada de um travesti importante, ao passo que, na entrevista inicial, ele próprio dá a ordem de não deixar entrar "bicha louca, crioulo e traficante":

vê se usa um pouco de inteligência, só porque você é leão de chácara não precisa ser tão burro. Vamos ver se eu entendi, eu disse, piçudo porque tinha 
chamado aquele cagalhão de senhor enquanto ele tinha me chamado de burro...

Está bem claro que o conflito se passa entre os dois elementos da troca conversacional: o leão-de-chácara e o patrão. O personagem está inconformado de ter tratado o patrão, com quem discute, de "senhor", e de ter sido tratado de burro:

Essaie d'être un peu plus intelligent; ce n'est pas parce que tu es cerbère que tu dois être un âne. On va voir si j'ai compris, que j'ai dit, hors de moi, parce qu'il avait appelé cette crotte, Monsieur, alors qu'il m'avait traité d'âne...

Há uma confusão, atribuindo o tratamento de "senhor" do patrão ao cliente travesti e não a seu interlocutor.

Vale salientar que o conto é pontuado pela expressão "Puta merda", bem traduzida por "Bordel de Merde" que mantém o impacto do original.

\section{"Dia dos namorados" I "La Saint-Valentin"}

Paulo, mais conhecido como Mandrake, nos conta uma história ocorrida no dia dos namorados. De imediato, no primeiro parágrafo, ele introduz a história central, de como, em pleno dia dos namorados, o advogado Medeiros solicita os serviços do personagem para resolver um caso de chantagem:

Se há uma coisa que eu não engulo, é chantagista. Se não fosse isso, não sairia de casa naquele sábado, por dinheiro nenhum do mundo.

O relato será intercalado: a história da chantagem do travesti e a história de como Mandrake conheceu a loura grã-fina. Há, pois, um paralelo entre as figuras femininas, símbolos de extremos, da alta e da baixa sociedade. E se, por um lado, o leitor tem por completo a história do travesti, por outro, pode-se intuir qual seria a história que não ocorreu, a de Mandrake com a grã-fina, quando Mandrake anuncia "o que vai acontecer aqui, entre nós dois, será diferente de tudo que já 
aconteceu contigo, minha princesa". O leitor de Rubem Fonseca pode facilmente intuir a história escabrosa da qual a loura grã-fina escapou.

Quanto ao chantageado, J.J. Santos, um banqueiro mineiro, esse terá seu nome sempre citado de forma integral até descobrir o engodo (que a mulher que ele pegou na rua era um homem). Após o ocorrido, Rubem Fonseca opta por amputar o sobrenome ao personagem, por vezes abreviando-o, por outras, omitindo-o: J.J.S. ou J.J, por vezes substituindo-o pelo pronome il. A nosso ver, essa opção do autor tem um significado: retira-se do personagem parte de sua identidade, de sua virilidade. Esse constitui o primeiro mal-entendido na tradução, quando toma-se a liberdade de abreviar esse nome antes do "pédale", no parágrafo 27:

\section{Português}

Às oito horas J.J. Santos saiu da igreja, pegou o seu Mercedes e foi para a casa dos pais da noiva, em Ipanema. O apartamento estava cheio, J.J. Santos cumprimentou as pessoas, brincou com os noivos, e meia hora depois saiu sem ser notado

\section{Francês}

A huit heures, J.J. Santos sortit de l'église, prit as Mercédès et se rendit chez les parents de la mariée, à Ipanema. L'appartement était plein. J.J.S. salua tout le monde, plaisanta avec les nouvaux mariés, et une demie heure plus tard, sortit sans être remarqué.

Nos quatro contos há uma série de pequenas omissões, acréscimos, inversões que não chegam a comprometer a intenção original e que, apesar de repertoriados, não são aqui citados. No entanto, vale salientar aqui uma série de ocorrências que, comprometendo ou não a compreensão do texto, são reveladoras das liberdades tomadas pela tradutora:

\section{Português}

O altar estava coberto de flores. A noiva, acompanhada do pai, desfilou lentamente pela nave da igreja, ao som das vozes de um coro afinado. $O$ noivo como sempre, estava com cara de besta esperando pela noiva, no altar.

\section{Francês}

L'autel était couvert de fleurs. La mariée, au bras de son père, remontait lentement la nef de l'église, au son des voix d'un choeur angélique Le marié, selon la coutume, attendait la mariée à l'autel, avec un air idiot. 
O autor enfatiza que o habitual é o noivo estar com cara de besta, enquanto a inversão evidencia que o habitual é o noivo esperar no altar.

A título de curiosidade, vale citar um curioso acréscimo, que parece aqui incompreensível:

\section{Português}

Eu também ri. Estávamos os dois muito interessados um no outro. Sou fissurado em mulher rica.

\section{Francês}

Je me mis aussi à rire. Elle est comme moi, nous étions très attires l'un par l'autre. Je raffole des femmes riches.

Uma outra curiosidade também merece comentário após cotejo:

\section{Português}

Não vou, a mulher de J.J. Santos disse, você vai. Ela preferia ficar vendo televisão e comendo biscouto. Casados há dez anos, estavam naquele ponto em que você se conforma e morre encarcerado ou chuta a mulher pro alto e fica livre.

\section{Francês}

Je n'y vais pas, dit la femme de J.J. Santos, vas-y, toi. Elle préférait rester à regarder la télévision et à manger des petits gãteaux. Mariée depuis diz ans, ils en étaient au stade où l'on se dit, je m'y fais et je meurs dans cette galère, ou bien je me débarasse de ma femme et je suis libre.

Excetuando-se o erro em "Mariée" (provavelmente involuntário, correção: mariés), essa passagem de um trecho narrativo para uma tradução transformada em discurso direto revela como a tradutora toma a liberdade de utilizar os recursos característicos do autor em prol de uma produtividade na tradução. A nosso ver, trata-se de uma inteligente traição.

A omissão do parágrafo 50 , embora pareça tipicamente uma omissão involuntária da tradutora, compromete a totalidade do texto: 


\section{Português}

Afinal, qual o seu nome? Paulo, Mandrake, Picasso?

A pergunta não é essa, respondi. Você tem que me perguntar, afinal quem é você?

Afinal, quem é você?

Não sei, respondi.

A paranóia está atacando também a classe C!, disse a loura.

\section{Francês}

Finalement, comment t'appelles-tu? Paulo, Mandrake, Picasso ?

Ce n'est pas la bonne question, répondisje. Tu dois me demander, finalement, qui es-tu?

\section{OMISSÃO}

Je ne sais pas, répondis-je.

La paranoïa s'attaque aussi à la petite bourgeoisie, dit la blonde.

Para encerrar esta parte, atente-se para o fato de haver ocorrido adaptação em dois momentos. O primeiro na substituição da moeda, cruzeiro, pelo franco francês e, em seguida, do refrigerante "guaraná" pelo refrigerante francês "orangina". As opções de manutenção ou adaptação de elementos tipicamente brasileiros revelam-nos apenas a preocupação da compreensão pelo público-alvo.

No tocante à seleção lexical do vocabulário gírio e chulo dos quatro contos, o levantamento inicial dos palavrões e gírias é base de breves comentários acerca dos termos mais utilizados e de algumas das opções da tradutora, com o objetivo de esclarecer o contexto, quando necessário.

O vocabulário básico do malandro carioca dos anos 1970, que hoje pertence à gíria comum, tem correspondente em francês, sem maiores problemas: flic = tira; fric (quelques) sacs = grana (firme); nanas = mulherio; piquer = afanar, faucher une voiture = puxar um carro; piquer $=$ afanar; bagnole $=$ rodante . Bacana, uma gíria datada dos anos 1970, na maioria das vezes traduzida por chic ou bien: as lojas bacanas = les boutiques bien; uma casa bacana = une maison chic. Entretanto, às vezes, bacana é traduzido apenas por formidable, perdendo seu status de gíria, e outras vezes nem sequer é traduzido.

Quanto às palavras de baixo calão, com conotação sexual, escatológicas ou blasfêmias, em geral, há equivalência na tradução sem grande ônus do registro "chulo" para o leitor estrangeiro. Segue uma breve seleção: merde para merda; cochonnerie para bosta; putain para puta que pariu; mal foutu/foutu/dégueulasse para fudido; con para boceta; couilles para culhões; se branler para bater/tocar uma punheta, ou se taper une pignole para descascar uma bronha; enfant de 
putain para filha da puta; ${ }^{84}$ salaud para bunda suja, puto, sacana (embora, para puto, a opção da tradutora nem sempre seja salaud); baiser para foder; pédale para viado.

O termo porra aparece diversas vezes no texto, e em todas é traduzido por Nom de Dieu. Surpreende-nos a opção da tradutora, pois o termo de origem é de ordem sexual, enquanto o correspondente utilizado é uma blasfêmia. Em francês, as blasfêmias são expressões muito fortes, e Nom de Dieu poderia corresponder a porra, não fosse a possibilidade de se utilizar merde, expressão tão consagrada na França, de origem escatológica. ${ }^{85}$

Ao empregar, de forma ousada, vocábulos gírios e de baixo calão, Rubem Fonseca busca a fidelidade da transcrição de uma linguagem oral, construindo assim seus personagens no limite do possível da verossimilhança. Ao dar voz ao personagem-narrador, cria uma maior interação com seu leitor. O leitor acaba quase por compactuar com os marginais de "Feliz Ano Novo", condoer-se com Zé após a partida de futebol, exclamar "Puta merda!" com o leão de chácara e dividirse entre a aflição do banqueiro ou do travesti em "Dia dos Namorados" ! Ao pensamos no contexto de sua concepção, podemos ver aí uma reação à situação vigente no país nos anos 70 , onde só havia duas possibilidades de atitude: a "nossa" (dos oprimidos, do autor, do leitor de Rubem Fonseca) e a "deles" (do poder repressor). O autor chama a atenção para a violência "banal", cotidiana dos marginais, buscando implicitamente contrapô-la a uma violência maior, ao abuso de poder. Ao mesmo tempo, descreve de forma realista a miséria efetiva de uma classe social e a miséria moral dos mais privilegiados em contos-denúncia, espelhando uma reação literária marginal intencional.

\footnotetext{
${ }^{84}$ Embora haja outras possibilidades adotadas pelo tradutor Philippe Billé que talvez sejam mais freqüentes na oralidade atual francesa, como "fils de pute", "fils d'une pute", "fils de putain".

${ }^{85}$ Philippe Billé, por exemplo, o segundo tradutor de Rubem Fonseca na França, optou por "merde" para a tradução de "porra" nos romances por ele traduzidos.
} 


\section{O caso Morel I Le cas Morel}

O primeiro aspecto a chamar a atenção na tradução de $O$ caso Morel é a manutenção de certos nomes próprios como Zé, Roberto, Cristina, Joana, Lígia, e a tradução de outros como Monique, Diane, Guillaume, Dorothée, Ismène e Albert.

Ainda quanto a nomes próprios, dessa vez no que se refere a marcas de carros, a tradutora optou por adaptar a modelos mais conhecidos do público leitoralvo:

Página

31

"Meu carro é um Karman Ghia vermelho.

92 O banqueiro era um velho muito feio, que chegava de Galaxie, usava uma medalha de São Jorge no pescoço, um sujeito repugnante."
Francês

- Ma voiture est une Passat rouge.

Il était vieux, moche, il arrivait en Ford, il avait une médaille de Saint-Georges au cou, un type répugnant.
Página

38

112

No primeiro caso, não havia a necessidade de substituir o modelo Karman Ghia por um mais atualizado, pois ele foi um conhecido modelo esporte da Volkswagen, produzido de 1955 a 1974. Relíquia de colecionadores nos dias de hoje, o modelo foi sinônimo de esportividade e modernidade em sua época, e, por que não dizer, de virilidade. ${ }^{86}$

O mesmo pode se dizer do famoso Ford Galaxie ${ }^{87}$ (não confundir com o atual Galaxy) dos anos 1960-1970. Embora haja perda, o fato de citar a marca Ford ameniza os efeitos provocados pela solução precedente.

Outro aspecto a ser assinalado está presente nos diálogos travados entre o narrador, ainda criança, e o português Guimarães, com seu sotaque lusitano. Na passagem para a língua francesa, perde-se, evidentemente, o sotaque marcante na versão brasileira, evidenciado nas formas menos coloquiais de seu falar.

\footnotetext{
${ }^{86}$ Como pode ser observado no site: http://www.karmann-ghia.org/

${ }^{87} \mathrm{O}$ modelo pode ser apreciado no site:
} 


\begin{tabular}{|c|c|c|c|}
\hline Página & Português & Francês & Página \\
\hline 24 & $\begin{array}{l}\text { "És um menino magro, mas } \\
\text { és forte" }\end{array}$ & $\begin{array}{l}\text { - Tu es un garçon maigre, } \\
\text { mais tu es fort... }\end{array}$ & 29 \\
\hline 24 & $\begin{array}{l}\text { "Quanto é que ganhas na } \\
\text { oficina?" }\end{array}$ & $\begin{array}{l}\text { - Combien gagnes-tu à } \\
\text { l'atelier? }\end{array}$ & 30 \\
\hline 24 & "Pesa-te muito?" & - C'est lourd? & 30 \\
\hline 24 & $\begin{array}{l}\text { "Crês que podes carregá-la, } \\
\text { digamos, a manhã inteira?" }\end{array}$ & $\begin{array}{l}\text { - Tu crois que tu pourrais la } \\
\text { porter, disons... toute la } \\
\text { matinée? }\end{array}$ & 30 \\
\hline 25 & $\begin{array}{l}\text { "Deixe aí o mostruário, sabes } \\
\text { que só trabalhamos no } \\
\text { Centro." }\end{array}$ & $\begin{array}{l}\text { - Laisse la valise ici, tu sais } \\
\text { que nous travaillons } \\
\text { seulement au centre. }\end{array}$ & 30 \\
\hline 25 & "Vês aquele prédio?"... & - Tu vois cette maison? & 30 \\
\hline
\end{tabular}

Embora a tradutora, nos contos, tenha optado pela manutenção de alguns termos em português e inserido comentário em nota, compreende-se que esse procedimento não seja adotado constantemente em prol de uma leitura mais fácil para os franceses, como é o caso, a título de exemplo, para "guaraná" ou "cruzeiros":

\section{Página \\ Português \\ Francês \\ Página \\ $9 \quad$ Pedi um uísque. Ela só tinha coca ou guaraná. \\ Je lui demandai un whisky. \\ Elle n'avait que du coca-cola ou du soda. \\ $9 \quad$ Os duzentos cruzeiros? - Les deux cents balles? \\ Note-se, no segundo caso, que a tradutora de certa forma compensou a tradução de "cruzeiros" optando por um vocábulo gírio: "balles". Algo semelhante ocorre com passagens nas quais parece haver um tipo de reforço do linguajar chulo, quando não é o caso em português:}

$<$ http://www.allsportauto.com/modules.php?name=Sportphoto\&zl_idMD=1028>. 
Página Português Prancês Página

38 Pensei numa porção de J'essayai de penser à des $\quad 47$

libidinagens, sem efeito.feito. trucs porno, sans effect.

Os procedimentos compensatórios citados são muito mais raros que as eufemizações, cometidas em vários níveis, como se verifica a seguir:

Página Português Prancês Página

15 Caixas, objetos, montagens Boites, objets, montagesfotográficas, fazia coisas photo, je faisais ce genre de assim, pois na verdade eu choses parce qu'en réalité havia secado. j'étais sans inspiration. yeux marron de Cristina... os olhos castanhos de Cristina...

Um primeiro nível de eufemização ocorre nos dois exemplos citados quando uma expressão gíria é substituída por outra mais refinada, como no caso de "secar" ter seu equivalente em "estar sem inspiração", ou ainda, na substituição da imagem "camada líquida" pela denotação "lágrima". Pode-se considerar que essas opções, apesar de "traírem" o original, não comprometem elementos essencialmente sociais e o entendimento do leitor estrangeiro. No entanto, observe-se o segundo nível: 
Página

Português

Francês

Página

8 Ela tinha um sotaque de Elle avait un accent étranger, 10 gringa européia. européen.

18 ...respondeu ela, imitando o ...me répondit-elle, en imitant 23 tom de saco cheio da minha mon ton excédé.

voz.

70 Não, não tenho mais saco - Non, je n'ai plus le 86 para viver com uma mulher courage de recommencer à apenas, novamente. vivre avec une seule femme.

Os três exemplos citados mostram, nas opções da tradutora, uma amenização flagrante. O primeiro não comporta na tradução a carga pejorativa da palavra "gringa", conhecida pelos franceses. Nos segundo e terceiro exemplos, o nível de linguagem é completamente transformado, do coloquial para o refinado.

Em um terceiro nível, figuram dois exemplos extremos, o primeiro escatológico e o segundo sexual:
Página
Português
Francês
Págin
40 Faz xixi na minha mão.
- Fais pipi dans ma main.
49
58

...um artista decadente quer
comer uma grã-fina chata,
mas ela só dá para ele se for
apresentada a um astrólogo
chamado professor Khaiub.
...un artiste décadent veut
71 coucher avec une mondaine emmerdante, mais elle ne se donnera à lui que s'il la présente à un astrologue, un dénomné Khaiub.

Quando se sabe o contexto, chega a ser curiosa a solução da tradutora. Um casal está se excitando nas premissas de um ato sexual, quando o homem diz à mulher: "Faz xixi na minha mão". Não se entende por que a tradutora não utilizou o verbo "pisser" e optou por uma solução que parece remeter o leitor a uma conversa entre crianças. É que a expressão "fazer xixi" serve em português para ambos os contextos, embora possa se utilizar o verbo "mijar", mais agressivo. No entanto, em francês "faire pipi" está mais adequado a um registro infantil ou, alguns argumentarão, afetivo. No entanto, a cena é carregada de erotismo e forte 
linguagem sexual, revelando que a opção da tradutora, além de não se mostrar adequada ao contexto, eufemiza o roiginal.

No segundo caso, a elegante expressão francesa "se donner à" que corresponde a "entregar-se a" ameniza bastante o nível chulo presente no início do período. A opção por "coucher", no início do período, já é um elemento eufemizador, porém aceitável.

\section{As marcas sociais e culturais nas traduções em antologias e coletâneas}

A segunda abordagem consistiu em apreciar os contos presentes em antologias e coletâneas algumas das opções dos tradutores diante de marcas culturais e sociais presentes nos textos fonsequianos.

O quadro que segue apresenta a relação de contos dentre os elencados no Capítulo I, aos quais se teve acesso durante a pesquisa. Embora não representem a totalidade dos contos de Rubem Fonseca publicados em língua francesa, e mais especificamente na França, sua apreciação, como amostragem, fornece elementos para a presente reflexão.

\begin{tabular}{|l|c|c|c|}
\hline Conto & $\begin{array}{c}\text { Ano de } \\
\text { publicação } \\
\text { Brasil/França }\end{array}$ & Publicação & Tradutor \\
\hline
\end{tabular}




\begin{tabular}{|c|c|c|c|}
\hline "O outro" / "L'autre" & $1975 / 1982$ & $\begin{array}{c}\text { Europe, Revue Littéraire } \\
\text { Mensuelle }\end{array}$ & $\begin{array}{l}\text { Daisy da } \\
\text { Conceição Elísio } \\
\text { \& Mariangela dos } \\
\text { Santos Paulo }\end{array}$ \\
\hline "Gazela" / "Gazelle" & 1963/1991 & $\begin{array}{l}\text { Anthologie de la } \\
\text { nouvelle latino- } \\
\text { américaine }\end{array}$ & Lyne Strouc \\
\hline $\begin{array}{l}\text { "Relatório de ocorrência em que } \\
\text { qualquer semelhança é não mera } \\
\text { coincidência" / "Compte rendu de } \\
\text { circonstances où toute } \\
\text { ressemblance n'est pas pure } \\
\text { coïncidence". }\end{array}$ & $1967 / 1993$ & $\begin{array}{l}\text { Menaces - Anthologie } \\
\text { de la nouvelle noire et } \\
\text { policière latino- } \\
\text { américaine }\end{array}$ & $\begin{array}{l}\text { Jean-Claude } \\
\text { Vignol }\end{array}$ \\
\hline "O outro" / "L'autre" & $1975 / 1997$ & $\begin{array}{l}\text { Contes de Noël } \\
\text { Brésiliens }\end{array}$ & Jacques Thiériot \\
\hline $\begin{array}{l}\text { "O balão Fantasma" / "Le ballon } \\
\text { fantôme" }\end{array}$ & $1995 / 1998$ & Des nouvelles du Brésil & Philippe Billé \\
\hline $\begin{array}{l}\text { "Almoço na serra no domingo de } \\
\text { carnaval" / "Déjeuner à la } \\
\text { montagne un dimanche de } \\
\text { carnaval" }\end{array}$ & $1979 / 2005$ & $\begin{array}{l}\text { Europe, Revue Littéraire } \\
\text { Mensuelle }\end{array}$ & Florent Kohler \\
\hline
\end{tabular}

\section{Três versões de "L'autre" / "O outro"}

Ao observar o quadro citado, certos elementos atraem de imediato a atenção do leitor. Primeiramente, o fato de constarem duas traduções do conto "O outro". São, ao todo, três diferentes traduções do mesmo conto, ao incluir-se a antologia Feliz ano novo, traduzida e publicada em 1979 na França, juntamente com O caso Morel. Em 1982, Daisy da Conceição Elísio e Mariangela dos Santos Paulo foram as tradutoras do conto para a Revue Europe, organizada por Serge Bourjea. Em 1997, foi a vez de Jacques Thiériot traduzir o conto para a coletânea Contes de Noël brésliens.

Poucos elementos diferenciam as três versões. Cabe aqui ressaltar alguns elementos que possibilitam distinguir diferentes posições de tradutores diante do mesmo texto. 
O primeiro elemento a ser apontado é que a utilização de "francos" na versão de 1979 parece torná-la mais domesticadora que as outras duas versões que mantiveram a moeda brasileira da época, o "cruzeiro". Na versão de 1979, a mãe do pedinte se encontra apenas doente/malade. Nas duas outras versões mantém-se a informação de que a mãe está morrendo, e a versão de 1997 parece mais adequada, mais fluente, sobretudo se se considerar que a utilização mais atual do termo "remède" em francês equivale a "solução" e não a medicamentos, como se utiliza na versão 1982.

\begin{tabular}{|c|c|c|c|}
\hline Original & Versão 1979 & Versão 1982 & Versão 1997 \\
\hline $\begin{array}{l}\text { Na hora do } \\
\text { almoço o mesmo } \\
\text { sujeito } \\
\text { emparelhou } \\
\text { comigo, pedindo } \\
\text { dinheiro. "Mas } \\
\text { todo dia?", } \\
\text { perguntei. } \\
\text { "Doutor", ele } \\
\text { respondeu, } \\
\text { "minha mãe está } \\
\text { morrendo, } \\
\text { precisando de } \\
\text { remédio, não } \\
\text { conheço ninguém } \\
\text { bom no mundo, só } \\
\text { o senhor." Dei a } \\
\text { ele cem } \\
\text { cruzeiros. }\end{array}$ & $\begin{array}{l}\text { Á l'heure du déjeuner } \\
\text { le même individu } \\
\text { m'aborda et me } \\
\text { demanda de l'argent. } \\
\text { "Mais, tous les jours?", } \\
\text { lui demandai-je. } \\
\text { "Monsieur répondit-il, } \\
\text { ma mère est très } \\
\text { malade, elle a besoin } \\
\text { de médicaments, je } \\
\text { ne connais personne } \\
\text { de bon au monde, à } \\
\text { part vous." Je lui } \\
\text { donnai cinquante } \\
\text { francs. }\end{array}$ & $\begin{array}{l}\text { Á l'heure du déjeuner le } \\
\text { même individu est } \\
\text { apparu, à côté de moi, } \\
\text { de demandant de } \\
\text { l'argent. "Mais tous les } \\
\text { jours?", ai-je remarqué. } \\
\text { "Monsieur", a-t-il } \\
\text { répondu "ma mère est } \\
\text { en train de mourir, elle } \\
\text { a besoin de remèdes, } \\
\text { je ne connais personne } \\
\text { de généreux au monde, } \\
\text { sauf vous-même." Je lui } \\
\text { ai donné cent } \\
\text { cruzeiros. }\end{array}$ & $\begin{array}{l}\text { Á l'heure du } \\
\text { déjeuner le même } \\
\text { type m'a abordé et } \\
\text { a quémandé de } \\
\text { l'argent. "C'est } \\
\text { tous les jours } \\
\text { maintenant?" je lui } \\
\text { ai demandé, } \\
\text { "Monsieur", a-t-il } \\
\text { répondu "ma } \\
\text { mère est } \\
\text { mourante, elle a } \\
\text { besoin de } \\
\text { médicaments, je } \\
\text { ne connais } \\
\text { personne de bom } \\
\text { en ce monde, à } \\
\text { part vous." Je lui } \\
\text { ai donné cent } \\
\text { cruzeiros. }\end{array}$ \\
\hline
\end{tabular}

A versão de 1979 utiliza o passé simple, o que não ocorre nas outras versões. Muitos poderiam argumentar que o uso do passe composé nas versões de 1982 e 1997 torna o conto mais coloquial, o que é uma marca de Rubem Fonseca. No entanto, a opção pelo passé simple confere ao conto seu status de texto literário. 


\begin{tabular}{|c|c|c|c|}
\hline Original & Versão 1979 & Versão 1982 & Versão 1997 \\
\hline $\begin{array}{l}\text { De manhã fui } \\
\text { para o escritório e, } \\
\text { de certa forma, as } \\
\text { coisas } \\
\text { melhoraram um } \\
\text { pouco. Ao meio- } \\
\text { dia saí para dar a } \\
\text { minha volta. }\end{array}$ & $\begin{array}{l}\text { Le matin, je me } \\
\text { rendis au bureau et la } \\
\text { situation s'améliora un } \\
\text { peu. A midi, je sorti } \\
\text { faire ma promenade. }\end{array}$ & $\begin{array}{l}\text { Le matin suivant je suis } \\
\text { allé au bureau et, d'une } \\
\text { certaine façon, les } \\
\text { choses se sont un peu } \\
\text { améliorées. A midi, } \\
\text { comme d'habitude, je } \\
\text { suis sorti faire un tour. }\end{array}$ & $\begin{array}{l}\text { Le lendemain, au } \\
\text { bureau, les } \\
\text { choses d'une } \\
\text { certaine façon } \\
\text { s'étaient un peu } \\
\text { améliorées. À } \\
\text { midi, je suis sorti } \\
\text { pour ma } \\
\text { promenade. }\end{array}$ \\
\hline
\end{tabular}

Finalmente, há a omissão de um parágrafo nas versões mais recentes do conto. Muito provavelmente, existe uma versão em alguma publicação que suprime esse parágrafo na língua portuguesa e foi essa a fonte dos tradutores das versões de 1982 e de 1997. Essa explicação pode ser válida para a versão de 1982, mas não para a de 1997. Foram consultadas as duas possíveis fontes do tradutor, o original de Contos para um Natal brasileiro e Contos reunidos, que figura nas fontes à página 175 da edição francesa. Em ambas há o parágrafo que foi omitido.

\begin{tabular}{|l|l|l|l|}
\hline \multicolumn{1}{|c|}{ Original } & \multicolumn{1}{|c|}{ Versão 1979 } & Versão 1982 & Versão 1997 \\
\hline Resolvi parar de & $\begin{array}{l}\text { Je résolu d'arrêter de } \\
\text { travailler quelques temps. }\end{array}$ & & \\
trabalhar uns & $\begin{array}{l}\text { J'en parlai avec mes } \\
\text { tempos. Falei com } \\
\text { os meus colegas de } \\
\text { diretoria, que } \\
\text { concollègues, à la direction, ils } \\
\text { minha ausência a por } \\
\text { dois meses. }\end{array}$ & & \\
furent d'accord pour que je & prenne un congé de deux & & \\
mois. & & & \\
& & & \\
\hline
\end{tabular}

É surpreendente que esse conto tenha recebido três versões francesas. Sua temática, como já foi detalhado no Capítulo II, é bastante universalizante. O executivo que acredita estar sendo perseguido pelo mendigo não é um privilégio brasileiro. 
Perguntada sobre os critérios de seleção dos textos traduzidos na Revue Europe, Daisy da Conceição Elísio, atualmente professora e tradutora, uma das tradutoras do conto, relatou que era aluna de Português-Francês na Universidade do Rio de Janeiro na ocasião e que o professor Serge Bourjea convidou duas de suas alunas, Daisy da Conceição Elísio e Mariangela dos Santos Paulo para traduzirem o conto. ${ }^{88}$

A versão de $1997^{89}$ é de autoria de Jacques Thiériot, renomado tradutor de literatura brasileira. Atualmente instalado no Rio de Janeiro, Thiériot foi diretor de Alianças Francesas pela América do Sul (Equador, Peru e Brasil) antes de tornarse o diretor do Collège International des Traducteurs Littéraires em Arles, no sul da França. De todos os tradutores de Rubem Fonseca citados neste estudo, ele é seguramente o único que conseguiu se dedicar, como profissional, exclusivamente à tradução, durante parte de sua vida.

"Gazela" / "Gazelle"

O conto "Gazela" é um monólogo. O narrador está num bar e conta a um freguês, que não conhece, uma paixão da juventude. O leitor de Rubem Fonseca desconfia diante de uma história tão simples: dois jovens que se amavam e foram, num final de semana, para São Paulo, ao retornarem ao Rio de Janeiro, se separam.

Apenas uma incompreensível omissão na tradução desse conto merece aqui comentário. É notória a intertextualidade exacerbada de Rubem Fonseca, porém, o público francês é conhecedor de Ionesco. Não parece uma explicação plausível que a tradutora omitisse do texto o nome do autor romeno, que viveu quase toda sua vida em Paris, para facilitar a leitura de um francês.

\footnotetext{
88 Informação obtida via e-mail, em 19.1.2006, O contato com Jacques Thiériot, apesar de atualmente morando no Rio de Janeiro, foi mais difícil. Os demais tradutores citados mantêm contato via internet.

${ }^{89}$ Pertencente à Antologia Contes de Noel brésiliens, comentada no capítulo anterior.
} 


\section{Português}

Brindes são feitos para ocasiões festivas e eu estou no pior mood possível; não sou um homem de confidências, de contar tristezas, ou alegrias, de me abrir, para quem quer que seja, de fazer catarse com amigo ou padre, e no entanto aqui estou eu, colocando em cima da mesa todas as minhas dores e vergonhas para serem espiadas por um estranho que talvez não entenda o que está ouvindo. Muito obrigado. Não quero a sua compreensão. Ninguém entende ninguém: lonesco tem razão.

\section{Francês}

On trinque dans les fêtes, et moi, je suis dans la pire mood qui soit ; ça ne me ressemble pas de faire des confidences, de raconter mes peines ou mes joies, de m'ouvrir à qui que ce soit, de déballer mon linge sale devant un ami ou un prêtre, et pourtant je suis ici à exposer sur cette table toutes mes douleurs et mes hontes devant un étranger qui ne comprend peut-être même pas ce qu'il entend. Mais vous savez écouter, monsieur, et c'est ce qui compte, je vous en sais gré. Merci beaucoup. Je ne demande pas votre compréhension. Personne ne peut comprendre qui que ce soit.

A solução encontrada pela tradutora, contudo, para o erro de português que a amada cometeu é bastante própria:

\section{Português}

Eu estava gamado e tarado por essa garota, era como se ela fosse minha irmã, mãe, namorada e maior amigo, ao mesmo tempo. Eu gostava dela pra burro, o senhor entende? Um dia ela foi a Buenos Aires e me escreveu uma carta dizendo: viver sem você é dificel: com e.

Questionada se a seleção de "Gazela" para fazer parte da publicação fora por afinidade ao tema ou se havia outro critério, Lyne Strouc afirmou "Pour le
J'étais complètement baba devant cette fille, il me semblait qu'elle était tout à la fois ma soeur, ma mère, ma fiancée et mon meilleur ami. J'étais fou d'elle, vous comprenez ? Un jour, elle alla à Buenos Aires et m'envoya une lettre qui disait : 
choix, oui, c'était simplement par affinité". ${ }^{90}$ Lyne Strouc é jornalista, escritora e editora no sul da França, atualmente.

"Relatório de ocorrência em que qualquer semelhança não é mera coincidência"|"Compte rendu de circonstances ou toute ressemblance n'est pas pure coïncidence"

A tradução do conto por Jean-Claude Vignol é primorosa. Diretor da Aliança Francesa de Natal, Rio Grande do Norte, de 1975 a 1981. tradutor ocasional, é o responsável pelas traduções dos contos "O inimigo secreto", de Caio Fernando Abreu, e "A corrente de ouro", de Josué Guimarães, para a mesma publicação.

Indagado sobre os critérios de seleção dos contos, Vignol disse que não conhecia Rubem Fonseca até então, e que depois veio a ler Un été brésilien, na edição de bolso. A seleção foi feita pelo organizador, Olver Gilberto de Leon. ${ }^{91}$

No conto, uma vaca é atropelada por um ônibus numa estrada. Algumas pessoas morrem. Os habitantes do lugar se aproximam da vaca e começam a esquartejá-la e transportá-la para suas casas. A cobiçada carne da vaca morta é o centro do conto e das possíveis disputas: os homens com facões rivalizam na palavra o direito de pegarem uma parte.

\section{"O balão fantasma"/Le ballon fantôme"}

Este é o único conto traduzido por Philippe Billé, tradutor dos romances de Rubem Fonseca a partir de $A$ grande arte, em 1986, que foi efetivamente publicado.

"O balão fantasma" é um longo conto, considerado antiecológico, pois conta a história de policiais e balonistas no Rio de Janeiro, as personagens se dividem entre a fascinação e a consciência ecológica, seguindo um balão gigante que cairá no mar de Ipanema.

\footnotetext{
90 "Quanto à escolha, sim, foi apenas por afinidade". Informação obtida via e-mail em 31.3.2006.

91 Informação obtida via e-mail em 23.1.2006.
} 
Extenso e com um vocabulário bastante específico (dos baloeiros), esse conto não poderia ter tido melhor tradutor, pois Philippe Billé é quem talvez melhor conheça a narrativa fonsequiana na França. Vale salientar que ele mantém ao longo do conto o termo "baloeiros" em português. Não obstante sua experiência revelada nas traduções dos romances, Billé se equivoca ao traduzir o nome da personagem "Fodão", que no português, embora tome como origem um termo relacionado ao campo semântico sexual, teria o sentido gírio positivo "daquele que é considerado bom no que faz". Sua opção por "Enculé", ainda que no francês o termo também seja tomado do vocabulário sexual - "alguém que participa passivamente do coito anal", revela na verdade tratar-se, na linguagem chula, de "um pobre coitado", podendo, aliás, ser um xingamento. Atualmente, na França, o termo "enculé" é muito empregado em coro em campos de futebol, no exato momento da cobrança de um pênalti, pelos torcedores do time que tem a vantagem do pênalti prestes a fazer o gol. Em português, o termo francês sugere antes semelhança com o termo "Fodido" (no sentido de "enrabado"), antepondo-se ao "Fodão", no sentido de "expert".

Sobre a escolha do texto, declara Billé que "quant au contact pour 'Le ballon fantôme', je ne me souviens pas bien. Je sais que je n'ai fait aucune démarche puisque je n'étais pas au courant du projet d'anthologie, je pense que Madame Métailié m'a téléphoné". ${ }^{92}$

\section{"Almoço na serra no domingo de carnaval" / "Déjeuner à la montagne un dimanche de carnaval"}

O antropólogo Florent Kohler, docente em Estudos Brasileiros, no Instituto de Estudos Hispânicos e Portugueses da Universidade de Tours, traduziu esse conto, no qual o narrador conta seu retorno à casa onde viveu na serra carioca. Ele sobe a serra convidado para um almoço na casa da namorada. e é ao longo do conto que o leitor vai descobrindo que ele já fora morador daquela casa. No final do conto, ele estupra a namorada no jardim e vai embora.

\footnotetext{
92 "quanto ao contato para traduzir 'O balão fantasma', eu não me lembro muito bem. Sei que não tomei nenhuma iniciativa pois não estava a par do projeto de antologia, penso que a Senhora Métailié me telefonou".
} 
Ao ser questionado sobre os critérios de seleção do texto, Kohler respondeu, em português: "Quanto à escolha do texto, é porque era curto, eficiente, e me parecia dar uma idéia adequada do estilo de Rubem Fonseca, em termos de focalização, elipse, patologia, atritos sociais etc...". ${ }^{93}$

Tão direta e precisa quanto seu depoimento, a tradução de Kohler dispensa maiores comentários, apesar de optar pela supressão de pequenos trechos em vez de resolver alguns impasses, por exemplo quando omite elementos descritivos da maquiagem de um travesti que estava na estrada pedindo carona.

As respostas dos tradutores muitas vezes atribuíram a decisão da seleção aos editores. Elas permitem entrever que a subjetividade foi um dos fatores para a seleção dos contos: acesso às obras, indicações, afinidades pessoais. Por essa razão, manifesta-se no testemunho dos tradutores um inevitável componente aleatório. Apesar disso, a seleção de contos revela a superação de uma visão folclorizada do Brasil por meio de sua literatura. Um caráter universalizante permeia esses contos, cujas temáticas poderiam situar-se em qualquer região do planeta.

\section{Soluções apresentadas por Rubem Fonseca} ao tradutor Philippe Billé: correspondência inédita

O segundo tradutor de romances de Rubem Fonseca na França, como citado anteriormente, foi Philippe Billé, que iniciou uma longa correspondência, em português, com o escritor brasileiro, quando traduziu quatro de seus contos: "Teoria do consumo conspícuo", "Fevereiro ou março", "A matéria do sonho", "Relatório de ocorrência em que qualquer semelhança não é mera coincidência",

\footnotetext{
${ }^{93}$ Informação obtida via e-mail em 11.1.2006.
} 
no início de julho de 1985. Essas traduções de Billé nunca foram publicadas, segundo informação do próprio tradutor. ${ }^{94} \mathrm{O}$ último conto recebeu publicação, porém com a tradução de Jean-Claude Vignol. Na ocasião, em 1985, Philippe Billé estava sendo sondado para realizar a tradução de $A$ grande arte para a língua francesa e enviou os contos para a apreciação de Rubem Fonseca. No final de julho de 1985, Billé foi efetivamente escolhido pela editora Grasset para traduzir o referido romance. Rubem Fonseca colocou-se à sua disposição para esclarecer dúvidas. Iniciou-se assim uma colaboração entre autor e tradutor que duraria muitos anos e quatro traduções de romances. ${ }^{95}$

O contato com o tradutor para a realização deste estudo data de janeiro de 2004. Desde então, houve troca de informações com Philippe Billé, tanto via email quanto via correio. Alguns meses após o primeiro contato, Billé disponibilizou para este trabalho parte de seu material pessoal sobre as traduções que realizou de Rubens Fonseca para a língua francesa. O material abrange o período de julho de 1985 a fevereiro de 1996, e compreende: cartas de Philippe Billé a Rubem Fonseca, cartas de Rubem Fonseca a Philippe Billé, cartas da editora Grasset a Philippe Billé, e vice-versa, notas pessoais do tradutor e uma carta de Ricardo van Steen a Philippe Billé.

As sete primeiras cartas de Rubem Fonseca a Philippe Billé dizem respeito à tradução e publicação de $A$ grande arte na França, e os anexos das cartas n.3, 4 e 5 contêm verdadeiros glossários para os tradutores, que merecem estudo a parte. São documentos datilografados ou de próprio punho de Fonseca.

As cartas numeradas de 8 a 10 e seus anexos concernem a tradução e publicação de Bufo \& Spallanzani. Billé também incluiu anotações pessoais (n.11) As cartas de números 12 e 13 referem-se à tradução de Vastas emoções e pensamentos imperfeitos. Os anexos às cartas de número 14, 15 e 16 relacionamse à tradução de Agosto; e os de 17 a 19, à publicação em "livre de poche" de Agosto. Essas duas correspondências esclarecem, pelo menos parcialmente,

\footnotetext{
${ }^{94}$ Comentário de Philippe Billé manuscrito sobre carta de autoria de Rubem Fonseca, datada de 3 de julho de 1985: "Antes de traduzir romances, eu tinha submetido a RF quatro traduções de contos, que depois nunca foram publicados".
} 
quanto ao polêmico título que Agosto recebeu em língua francesa: Un été brésilien.

A carta de número 20 é uma carta sem relação com os documentos precedentes. Apresenta, porém, traços que confirmam o bom relacionamento entre o autor brasileiro e o tradutor francês. Dessa forma, considerou-se interessante citá-la e comentá-la. Eis um quadro recapitulativo:

\begin{tabular}{|c|c|c|}
\hline \multirow[t]{2}{*}{ DATA } & \multicolumn{2}{|c|}{ Natureza do documento } \\
\hline & Carta DE... & PARA... \\
\hline \multicolumn{3}{|l|}{ Material relativo a $\boldsymbol{A}$ grande arte } \\
\hline 1 - 3 de julho de 1985 & Rubem Fonseca & Philippe Billé \\
\hline $2-29$ de julho de 1985 & Rubem Fonseca & Philippe Billé \\
\hline $3-30$ de agosto de 1985 & Rubem Fonseca & Philippe Billé \\
\hline 4 - 9 de setembro de 1985 & Rubem Fonseca & Philippe Billé \\
\hline $5-27$ de setembro de 1985 & Rubem Fonseca & Philippe Billé \\
\hline $6-21$ de novembro de 1985 & Rubem Fonseca & Philippe Billé \\
\hline $7-31$ de julho de 1986 & Rubem Fonseca & Philippe Billé \\
\hline \multicolumn{3}{|c|}{ Material relativo a Bufo \& Spallanzani } \\
\hline 8 - 25 de dezembro de 1987 & Philippe Billé & Rubem Fonseca \\
\hline $9-6$ de janeiro de 1988 & Rubem Fonseca & Philippe Billé \\
\hline 10 - 29 de fevereiro de 1988 & Philippe Billé & Rubem Fonseca \\
\hline 11 - Fevereiro de 1988 & \multicolumn{2}{|c|}{ Notas pessoais - Philippe Billé } \\
\hline \multicolumn{3}{|c|}{ Material relativo a Vastas emoções e pensamentos imperfeitos } \\
\hline 12 - 30 de outubro de 1989 & $\begin{array}{l}\text { Grasset } \\
\text { Ariane Fasquelle }\end{array}$ & Philippe Billé \\
\hline $13-6$ de novembro de 1989 & Philippe Billé & $\begin{array}{l}\text { Grasset } \\
\text { Ariane Fasquelle }\end{array}$ \\
\hline \multicolumn{3}{|c|}{ Material relativo a Agosto (autor/tradutor) } \\
\hline 14 - 11 de novembro de 1991 & Philippe Billé & Rubem Fonseca \\
\hline 15 - 11 de novembro de 1991 & Rubem Fonseca & Philippe Billé \\
\hline 16 - 10 de dezembro de 1991 & Rubem Fonseca & Philippe Billé \\
\hline \multicolumn{3}{|c|}{ Material relativo a Agosto (autor/editora) } \\
\hline 17 - 18 de janeiro de 1996 & $\begin{array}{l}\text { Grasset } \\
\text { Jean-Pierre Decaens }\end{array}$ & Philippe Billé \\
\hline 18 - 26 de janeiro e 1996 & Philippe Billé & Grasset \\
\hline
\end{tabular}

95 Segundo Billé, não houve troca de correspondência para a realização da tradução de 0 selvagem da ópera. 


\begin{tabular}{|l|l|l|}
\hline $\mathbf{1 9}$ - 5 de fevereiro de 1996 & $\begin{array}{l}\text { Grasset Ariane } \\
\text { Fasquelle }\end{array}$ & Philippe Billé \\
\hline Material extra \\
\hline $\mathbf{2 0}-18$ de outubro de 1992 & Ricardo van Steen & Philippe Billé \\
\hline
\end{tabular}

O material a que se teve acesso é parcial e irregular. Por meio desse material, cedido por Philippe Billé, pode-se reconstituir parte da história das traduções dos romances de Rubem Fonseca na França, sobretudo das traduções de A grande arte, Bufo \& Spallanzani e Agosto. Também se podem encontrar, nas palavras do próprio autor brasileiro, indícios de como outras traduções para outras línguas foram tratadas.

As duas primeiras cartas de Rubem Fonseca a Philippe Billé são respostas do primeiro ao segundo e marcam o início da correspondência entre autor e tradutor. Fonseca confessa seu pouco domínio da língua francesa e satisfação com as traduções dos contos enviadas por Billé. Revela-nos ainda como vinham ocorrendo as traduções de $A$ grande arte para o espanhol e para o inglês. Já nos primeiros parágrafos, Rubem Fonseca revela a relação que mantém com seus tradutores e a importância que dá às traduções de suas obras:

Quando conheço bem a língua para a qual estou sendo traduzido, como o inglês e o espanhol, por exemplo, eu sempre incluo no contrato a exigência de que a tradução me seja submetida para aprovação. No momento estou revendo a tradução americana de A grande arte, feita por Ellen Watson. À medida em que (sic) ela vai traduzindo os capítulos, eles me são enviados.

Infelizmente o meu conhecimento do francês é um pouco deficiente. Eu leio com relativa facilidade, mas não domino a língua para poder dar uma opinião segura sobre a qualidade da tradução. De qualquer forma pude perceber que o ritmo do meu texto foi recriado por você, com fidelidade. Li as traduções com grande prazer. (Rio, 3 de julho de 1985)

Eis alguns trechos relevantes da segunda carta:

Acabo de receber o seu aerograma em que você me comunica que foi escolhido pela Grasset para traduzir a Grande Arte. A revisão deste livro, infelizmente, não foi bem feita e tem muitos erros, que só fui verificar ao fazer (ainda estou no meio) a revisão da tradução para o inglês. A tradução espanhola, que estou enviando para você em separado, também teve a minha colaboração e o texto dela está corrigido em muitos dos enganos, mas não todos. 
EU ESTOU À SUA INTEIRA DISPOSIÇÃO PARA QUALQUER DUVIDA QUE VOCÊ TENHA. É só me escrever que eu responderei imediatamente...

Como o meu conhecimento de francês é muitíssimo inferior ao meu conhecimento do inglês e do espanhol, não sei se vale a pena você fazer o que estes tradutores fizeram, isto é, me mandar todas as paginas da tradução à medida em que (sic) elas foram sendo feitas. Pense nisso e me diga, por favor, qual o método de trabalho que devemos utilizar para que a tradução saia o melhor possível.

Fico muito satisfeito de você ter sido escolhido para fazer a tradução do meu livro. É muito bom ter como tradutor uma pessoa que já conhece a sua literatura. (Rio, 29 de julho de 1985)

\section{A grande arte}

O documento 3 datado de 30 de agosto de 1985 é uma carta de Rubem Fonseca a Philippe Billé em resposta a algumas dúvidas do tradutor quanto à tradução de $\boldsymbol{A}$ grande arte. Fonseca se desculpa com o tradutor pela resposta tardia, explicando que estava terminando um romance, certamente trata-se de Bufo \& Spallanzani, lançado em 1986.

No final da carta, Fonseca diz não ter achado as perguntas do tradutor excessivas e coloca-se mais uma vez à disposição para quaisquer outros esclarecimentos, sublinhando essa parte: "Não achei as perguntas excessivas e estou à sua disposição para quaisquer outras que você quiser fazer. Para não perder tempo, vou remeter logo estas explicações. Vou ver se existe mais coisa, que a revisão que estou fazendo da tradução inglesa possa revelar, e escreverei em seguida para você".

Em 9 de setembro de 1985, Fonseca escreve (manuscrito) a Billé e envia um glossário (datilografado) que realizou com recomendações e esclarecimentos para os tradutores de língua francesa e espanhola de $A$ grande arte. Inclui ainda uma série de correções que pôde perceber na edição em português. Dentre essas recomendações, consta a manutenção de nomes próprios não-portugueses no original, o uso de aspas nos diálogos e não de travessão.

No final da carta, Fonseca informa Billé que a partir de outubro passaria dois meses na Alemanha: "Dia 6 de outubro vou passar dois meses e pouco na 
Alemanha. A Grande Arte recebeu o prêmio Goethe. Ainda não sei o meu endereço". ${ }^{96}$

Em 27 de setembro de 1985 há mais esclarecimentos sobre a tradução de A grande arte. O autor reforça que prefere o uso das aspas para os diálogos e não do travessão.

No final da listagem, Fonseca revela o nome de seu novo romance:

Meu novo romance chama-se Bufo \& Spallanzani, já está com a Editora Francisco Alves e deve sair em outubro, no final, durante a minha ausência. (O que não tem a menor importância pois não faço noites de autógrafos, não dou entrevistas nem promovo o livro de maneira alguma) Vou pedir que enviem o livro para você.

Fornece ainda datas de permanência e endereço na Alemanha (Berlim e Frankfurt) e encoraja Billé, mantendo-se, como sempre, à disposição do tradutor: "Estou com muita fé na sua tradução. Caso necessite qualquer outro esclarecimento, estou à sua disposição".

No dia 21 de novembro, já em Berlim, Fonseca escreve a Billé sugerindo um encontro na Alemanha.

A carta de 31 de julho de 1986 encerra a correspondência relativa à tradução de $A$ grande arte, já tratada como Du grand art pelo autor brasileiro. A carta contém justamente uma reflexão a propósito da mudança no título da obra tanto em inglês quanto em francês:

Ainda não recebi nenhum exemplar de DU GRAND ART. Provavelmente a Grasset enviou as cópias para a minha agência em Barcelona. A sucursal do Rio acaba de remeter um telex para a matriz pedindo esclarecimentos.

Quanto ao titulo, talvez a ambigüidade que eles buscaram com a modificação tenha algumas vantagens mercadológicas. Talvez.

A tradução inglesa, que já saiu nos Estados Unidos (Harper \& Row) também teve o titulo modificado. Eles preferiram HIGH ART, porque high (altura, força, forte, grande, poderoso, elevado, nobre, intenso, extremo, complexo, profundo, violento, etc. etc. etc.) Talvez seja uma palavra semanticamente mais rica do que great. (O sujeito em estado eufórico, devido a álcool ou droga, também está high). Enfim.

\footnotetext{
${ }^{96}$ Como já foi citado, entretanto, ambos se encontraram unicamente em março de 1987.
} 
Também nos revela que Billé leu Bufo \& Spallanzani e apreciou e já se viabilizava a tradução de Bufo para a língua francesa:

Fico satisfeito de você ter gostado do Bufo. Na Europa, por enquanto, só assinei contrato com a Piper, de Munique, para edição traduzida desse livro. (Em alemão, é claro). Não sei como está, e nem mesmo se existe, negociação com a Grasset, ou outra editora francesa, para a tradução do Bufo.

Seria um prazer continuar a ter você como meu tradutor. Pode propor, como sugeriu, a qualquer editora francesa, as traduções dos meus contos, ou mesmo do Bufo. Talvez a prioridade devesse ser da Grasset. As negociações contratuais teriam que ser feitas através da Carmen Balcells.

\section{Bufo \& Spallanzani}

O primeiro documento relativo à tradução de Bufo \& Spallanzani aqui apresentado é a cópia de uma carta do tradutor Philippe Billé a Rubem Fonseca (documento 8). Nela, o tradutor informa o escritor brasileiro que foi contratado pela editora Grasset para traduzir o livro em questão e que o rascunho da tradução já estava pronto. Restando algumas dúvidas, Billé envia uma lista de palavras e nomes, pedindo ajuda ao autor brasileiro.

A resposta de Rubem Fonseca (documento 9) esclarece as dúvidas do tradutor e reitera sua confiança no trabalho do tradutor francês. ${ }^{97}$

Recebi sua carta do dia 25 de dezembro, com as perguntas referentes ao Bufo e Spallanzani. Antes de mais nada quero dizer que fiquei muito satisfeito com o fato da Grasset ter escolhido você para traduzir mais esse livro meu. Sei que você irá fazer um belo trabalho.

Na segunda carta, quase dois meses depois da primeira, Billé agradece a resposta à sua primeira carta e a ajuda de Fonseca em suas dúvidas ("Muito obrigado por sua resposta do mês passado, que me ajudou") e assinala ainda uma série de erros de ordem tipográfica no original em português ("Acabei com o trabalho e vou mandá-lo para Grasset hoje ou amanhã. Mando-lhe esta carta para avisar de algumas correções ou modificações que fiz, e de erros tipográficos que encontrei: pode ser útil para aperfeiçoar a impressão de novas edições em 
português ou para tradução em outras línguas"). No final, Billé solicita a aprovação de Fonseca para suas correções antes da impressão final pela editora:

Daqui a um mês ou dois, Grasset deve me mandar as provas do livro, para pedir uma última releitura e meu imprimatur. Portanto, caso você quiser corrigir algo que deixei, ou caso contrário, se não concordar, porque também considero a possibilidade de eu me ter equivocado, ainda é tempo. Estou à sua inteira disposição.

O documento 10 consiste em anotações do tradutor a respeito da tradução de Bufo \& Spallanzani. Esse documento foi provavelmente enviado à editora antes da publicação da tradução (1989). Não há indicações de haver passado pelo crivo de Rubem Fonseca.

\section{Vastas emoções e pensamentos imperfeitos}

O primeiro documento que se refere a essa tradução é uma carta da editora Ariane Fasquelle ao tradutor (documento 12). Nela, a editora agradece dois exemplares da tradução que lhe foram enviados por Billé e comunica ter encontrado Rubem Fonseca em Grenoble:

Merci pour les deux exemplaires de votre traduction qui est vraiment très bien. J'ai vu Rubem Fonseca à son retour de Grenoble où il était invité au Festival du roman noir. II m'a remis une page de corrections (ci-jointe). J'en profite pour vous signaler quelques points de détail (cf. pages manuscrit). ${ }^{98}$

A editora comenta alguns itens que Ihe pareceram estranhos na tradução de Philippe Billé e pede esclarecimentos.

No encerramento da carta, nota-se que a publicação da tradução é iminente:

\footnotetext{
${ }^{97}$ Essas duas cartas serão alvo de comentário ao final da apresentação da correspondência.

98 "Obrigado pelos dois exemplares de sua tradução que é verdadeiramente muito boa.

Vi Rubem Fonseca em seu retorno de Grenoble, onde ele foi convidado para o Festival do romance 'noir'. Ele me entregou uma página de correções (em anexo). Aproveito para apontar alguns detalhes (cf. páginas manuscrito)."
} 
J'attends de vos nouvelles pour donner le manuscrit au service de fabrication. Je risque de m'absenter quelques semaines vers le 15 novembre et j'aurais aimé, si cela était possible, que ces questions soient résolues avant. ${ }^{99}$

A essa carta da editora, responde Philippe Billé, em 6 de novembro de 1989:

Bonjour. De retour de la campagne, j'ai trouvé ce matin votre lettre du 30 octobre et, comme vous me demandez de faire vite, je réponds sans tarder à vos questions. ${ }^{100}$

O tradutor desculpa-se ainda pelos mal-entendidos da tradução, esclareceos, e coloca-se à disposição da editora:

Je regrette tout à fait les malencontreuses paronomases qui se sont glissées dans le texte de ma traduction de Vastas Emoções, aux pages .....du manuscrit. Je vous propose les solutions suivantes...

Voilà. J'espère que cette lettre vous parviendra avant votre départ. N'hésitez pas à m' en parler, si vous trouvez d'autres problèmes. ${ }^{101}$

Não se teve acesso a nenhuma correspondência direta entre o autor brasileiro e seu tradutor francês relativa à tradução de Vastas emoções e pensamentos imperfeitos. No entanto, a carta de Billé a Ariane Fasquelle nos esclarece sobre alguns itens que o tradutor achou por bem corrigir ou omitir, por repetições e incoerências semânticas no texto original (por exemplo, um "coronel" que seis linhas à frente é chamado de "general"). O anexo à primeira carta aqui comentada, de Ariane Fasquelle a Philippe Billé, contém sugestões de

\footnotetext{
99 "Espero notícias suas para entregar o manuscrito ao setor de produção. Corro o risco de me ausentar algumas semanas por volta do 15 de novembro e eu gostaria, se for possível, que essas questões sejam resolvidas antes."

100 "Bom dia. De volta do interior, encontrei esta manhã sua carta de 30 de outubro e, como me pede que não me demore, respondo imediatamente a suas questões."

101 "Lamento sinceramente as aborrecidas paranomásias que se introduziram no texto de minha tradução de Vastas Emoções, nas páginas .... do manuscrito. Eu lhe proponho as seguintes soluções...

Aí está. Espero que esta carta chegue antes de sua partida. Não hesite em me falar se encontrar outros problemas."
} 
modificações conseqüentes, como substituições de grandes trechos no capítulo 3 da parte "II Manuscrito", que foram realmente efetuadas pelo tradutor. ${ }^{102}$

\section{Agosto (I)}

No final de 1991, Philippe Billé entra novamente em contato com Rubem Fonseca, dessa vez a propósito da tradução de Agosto:

O senhor sabe, talvez, que fui contratado pela editora Grasset para traduzir seu romance Agosto. Já acabei com o rascunho da tradução e comecei a bater o manuscrito, que deve ser entregado (sic) até o fim de dezembro. Apesar de muita pesquisa, algumas palavras ficam misteriosas para mim. Me ajudaria se você pudesse esclarecer para mim o sentido das palavras cuja lista segue...

Sem tardar (no mesmo dia via internet) Rubem Fonseca responde a Philippe Billé:

Fiquei satisfeito em saber que a Grasset havia contratado você para fazer a tradução do Agosto. Não tenho dúvidas de que mais uma vez você fará um belo trabalho. Agora suas dúvidas...

Espero que você tenha ficado satisfeito com as respostas. Estou aguardando a publicação da edição francesa com muito interesse.

A lista de Philippe Billé aponta 24 dúvidas de tradução. Em razão do teor histórico de Agosto, ligado à política brasileira dos anos 1940, é normal que um número considerável de dúvidas seja com relação a siglas. Outro tipo de dúvida paira sobre vocabulário gírio, e um terceiro tipo pode ser identificado como especificamente local, como se verá mais à frente no cotejo das dúvidas e na resposta de Rubem Fonseca.

Ainda em novembro, Billé escreve a Fonseca (não houve acesso a essa carta), provavelmente comentando que se baseou na primeira edição original de

\footnotetext{
${ }^{102}$ Pela falta de certas cartas que poderiam ser esclarecedoras, não se pode aqui avaliar mais
} 
Agosto. Ao que o autor brasileiro responde elencando uma série de erros a serem corrigidos:

Recebi sua carta de 27 de novembro. É uma pena que a agência C. Balcells não tenha enviado, como parece, a segunda edição do Agosto para você. Aqui vão os erros que você deve corrigir:...

Rubem Fonseca relaciona dezenove erros do original em português, da primeira edição, que deveriam ser e que foram efetivamente corrigidos pelo tradutor na passagem para a edição francesa.

\section{Agosto (II)}

A publicação tanto de Du grand art (1995) como de Un été brésilien em formato "livre de poche", em 1996, ou seja, três anos após sua publicação, pode ser, como comentado anteriormente, um indício do sucesso dos romances na França. Na ocasião dessa última publicação, o tradutor foi consultado sobre eventuais correções na última edição do texto.

La parution de l'ouvrage référencé ci-dessus étant prévue au Livre de Poche, nous vous prions de bien vouloir nous faire savoir si vous souhaitez y apporter des corrections par rapport à la dernière édition. ${ }^{103}$

Em nota de página, figura igualmente a questão da atualização da página do autor: "Voir également s'il faut réactualiser la page du même auteur".

A resposta de Philippe Billé esclarece-nos um grande mal-entendido na publicação de Agosto na França. Eis a íntegra de sua carta à editora:

En réponse à votre lettre du 18, concernant le projet de reparution en Livre de poche du Roman de Rubem Fonseca, Un été brésilien: j'aimerais que l'on change à cette occasion le titre de ce livre. L'intitulé Un été brésilien, choisi par Ariane Fasquelle, ne convient pas bien, quoique l'action se déroule en août,

profundamente essa parte.

103 "Como está prevista a publicação no Livre de Poche da obra em referência acima, nos lhe pedimos a gentileza de nos comunicar se desejaria acrescentar correções em relação à última edição.” 
car les saisons étant inversées dans l'hémisphère austral, août au Brésil est en pleine hiver. Dans mon manuscrit j'avais traduit simplement le titre original Agosto par Août. Je me rappelle avoir corrigé à l'époque un jeu d'épreuves portant le titre provisoire Août 54, qui me semble mieux convenir.

Je vous pris de veiller à ce que l'on tienne compte de mes remarques à ce sujet, et à ce que je sois informé de l'option revenue.

Veuillez croire, cher Monsieur, à l'expression de mes sentiments les meilleurs. ${ }^{104}$

Em geral, os teóricos da tradução e a crítica especializada só têm olhos para os erros dos tradutores. Isso é normal ao se pensar que quanto melhor a tradução, mais "apagado" se encontra o tradutor. Nenhum epitexto relacionado ao título de Agosto em francês foi encontrado, além das cartas aqui mencionadas. Seu conteúdo exime o tradutor da responsabilidade de tal façanha, que recai sobre a equipe editorial e merece destaque nas reflexões finais deste estudo.

Quanto à tradução do romance O selvagem da ópera, Billé afirma não ter mantido nenhum contato com o autor. Dessa feita, considerou-se adequado não incluí-lo no presente corpus.

A relação autor/tradutor entre Rubem Fonseca e Philippe Billé pode ser facilmente apreciada por meio da correspondência à qual se teve acesso. Por diversas vezes, o autor brasileiro reitera sua confiança na competência de Philippe Billé como tradutor. Esse documento vem confirmar o teor desse relacionamento:

Em correspondência de 18 de outubro de 1992, o cineasta Ricardo van Steen se apresenta, declara sua intenção de realizar um filme com contos de Romance negro, na época a mais recente publicação de Fonseca no Brasil. Ricardo explica como chegou ao tradutor, solicitando a Philippe Billé a tradução dos contos:

\footnotetext{
104 "Em resposta a sua carta do dia 18, relativa ao projeto de publicação do Romance de Rubem Fonseca 'Un été brésilien', eu gostaria que fosse alterado, nessa ocasião, o título desse livro. Esse título, 'Un été brésilien', escolhido por Ariane Fasquelle, não é muito adequado, embora a ação ocorra em agosto, como as estações são inversas no hemisfério austral, agosto no Brasil é em pleno inverno. Em meu manuscrito eu havia simplesmente traduzido o título original, Agosto, por Août. Lembro-me de ter corrigido na época, um jogo de provas que levava o título provisório de Août 54, que me parece ser mais conveniente.

Peço-lhe a gentileza de cuidar para que se leve (sic) em conta minhas observações a esse respeito e para que eu seja informado da opção a que se chegou.

Aceite minhas cordiais saudações."
} 
Telefonei para minha mãe, Edla van Steen (não sei se o senhor a conhece) e pedi que ela entrasse em contato com o Rubem e o colocasse a par das minhas intenções. Se ele me autorizaria a traduzir o conto e se poderia sugerir o nome do tradutor. E voilá. Ele disse que o senhor seria a única pessoa gabaritada para o trabalho e me deu as suas coordenadas.

Philippe Billé manuscreve no final do documento "traduzi para ele este conto que não deu em nenhum filme que eu saiba".

Foram selecionados, à guisa de análise, por meio de amostragem do material contido na correspondência, dois momentos em que o tradutor francês questiona o autor brasileiro. Rubem Fonseca responde, esclarece as dúvidas de Billé e sugere soluções na maioria das vezes. Em seguida, procedeu-se ao exame entre as sugestões de Fonseca e as opções do tradutor no texto francês.

O primeiro quadro se refere a questões constantes das cartas trocadas durante a tradução de Bufo \& Spallanzani. A segunda listagem faz parte do material de tradução relacionado ao romance Agosto.

\section{Questionamentos do tradutor e sugestões do autor}

Ao se observar o questionamento do tradutor a seguir relacionado, pode-se notar que suas dúvidas estão em consonância com os aspectos problemáticos repertoriados e analisados na primeira parte deste capítulo: marcas nacionais, 
culturais, vocabulário gírio e de época, jogo de palavras que muitas vezes perdem sua força original.

\begin{tabular}{|c|c|c|}
\hline $\begin{array}{c}\text { Carta } \\
\text { Philippe Billé/Rubem } \\
\text { Fonseca (25.12.1987) }\end{array}$ & $\begin{array}{c}\text { Carta } \\
\text { Rubem Fonseca/Philippe } \\
\text { Billé (6.1.1988) }\end{array}$ & Texto em francês \\
\hline p.14: butesin & $\begin{array}{l}\text { p.14: picrato de butesin. } \\
\text { Butesin é o nome } \\
\text { comercial de uma } \\
\text { substância química } \\
\text { sintética (para-amino- } \\
\text { benzoil-butanol) } \\
\text { desenvolvida e } \\
\text { patenteada pelo } \\
\text { laboratório americano } \\
\text { Abbot. Talvez exista aí } \\
\text { na França. Picrato de } \\
\text { butesin é um ungüento } \\
\text { com ação anestésica, } \\
\text { analgésica e antiséptica, } \\
\text { muito usado em } \\
\text { queimaduras aqui no } \\
\text { Brasil. }\end{array}$ & \begin{tabular}{|l} 
Même avec le corps \\
|barbouillé de pommade \\
antibrûlure. (p.4)
\end{tabular} \\
\hline $\begin{array}{l}\text { p.14: minete (talvez o } \\
\text { francês minette?) }\end{array}$ & $\begin{array}{l}\text { p.14: minete. } \\
\text { Coito oral, praticado com } \\
\text { a aplicação da boca } \\
\text { sobre a genitália } \\
\text { feminina. Palavra } \\
\text { introduzida no Brasil } \\
\text { pelas prostitutas } \\
\text { francesas ou que se } \\
\text { diziam francesas (muitas } \\
\text { eram polonesas). }\end{array}$ & \begin{tabular}{|l} 
Dans les moments libres, \\
je lui lisais de la poésie, \\
elle aimait \\
particulièrement un \\
poème de Baudelaire qui \\
parle de cunnilingus, \\
« la très-chère était nue, \\
et, connaissant mon \\
cœur* », etc. (p.5)
\end{tabular} \\
\hline p.16: as raias do revólver & $\begin{array}{l}\text { p.16: raias de revólver. } \\
\text { São as estrias no interior } \\
\text { do cano, que servem } \\
\text { para orientar o projétil. }\end{array}$ & $\begin{array}{l}\text { ses rainures n'étaient } \\
\text { pas très résistantes, mais } \\
\text { pour Guedes cela n'avait } \\
\text { pas d'importance, il } \\
\text { espérait se servir le } \\
\text { moins possible de son } \\
\text { revolver. (p.7) }\end{array}$ \\
\hline & p.21: (ESSA & Je lui ai montré les \\
\hline
\end{tabular}




\begin{tabular}{|c|c|c|}
\hline & \begin{tabular}{|l|} 
CORREÇÃO É MINHA) \\
presença de leucoblastos \\
- mieloblastos e \\
linfoblastos. \\
Favor suprimir \\
leucoblastos e \\
linfoblastos. \\
A frase ficaria assim: \\
"presença de \\
mieloblastos que \\
permitiam", etc.
\end{tabular} & \begin{tabular}{|l|} 
résultats de l'examen, \\
ceux que vous avez entre \\
les mains : présence de \\
myéloblastes qui \\
autorisaient qu'un seul \\
diagnostic. (p.20)
\end{tabular} \\
\hline & \begin{tabular}{|l|} 
p.79: (ESSA \\
CORREÇÃO É MINHA) \\
safra 1981 \\
Favor corrigir para safra \\
1961. \\
Gustavo Flávio menciona \\
acontecimentos de \\
muitos anos antes. Não \\
pode ser 1981.
\end{tabular} & $\begin{array}{l}\text { Il y avait une bouteille } \\
\text { avec um reste de vin } \\
\text { français, du sanit-émilion } \\
\text { de 1961, un reste de } \\
\text { fromage. (p.66) }\end{array}$ \\
\hline $\begin{array}{l}\text { p.91: hiponga (e p.214: } \\
\text { hiponguice) }\end{array}$ & $\begin{array}{l}\text { p.91: Hiponga. } \\
\text { Gíria para hippie. (Ver } \\
\text { tambèm pg. 214) }\end{array}$ & \begin{tabular}{|l} 
Elle était habillée à la \\
|mode hippie, une jupe \\
Iongue, une chevelure \\
hérissée, des sandales, \\
un sac de toile en \\
bandoulière et elle sentait \\
une agréable odeur \\
d'aisselles. (p.76)
\end{tabular} \\
\hline p.92: zerada & \begin{tabular}{|l} 
p.92: zerada \\
reduzida a zero, nula, \\
sem nada (e portanto \\
sem dinheiro)
\end{tabular} & $\begin{array}{l}\text { Mais c'est toi qui payes, } \\
\text { parce que je suis } \\
\text { fauchée. (p.76) }\end{array}$ \\
\hline p.92: alto astral & $\begin{array}{l}\text { p.: alto astral } \\
\text { algo positivo, bom. }\end{array}$ & $\begin{array}{l}\text { À proximité de cette } \\
\text { |accumulation de livres } \\
\text { qui lui procurait un } \\
\text { sentiment de sécurité. } \\
\text { XXX (p.77) Omissão }\end{array}$ \\
\hline p.97: Xerife Lobo (é & \begin{tabular}{|l} 
p.97: xerife Lobo \\
Personagem de série \\
americana de Tv
\end{tabular} & $\begin{array}{l}\text { Laurence Olivier et le } \\
\text { shérife Lobo. (p.80) }\end{array}$ \\
\hline p.98: despirocado & $\begin{array}{l}\text { p.98: despirocado } \\
\text { sujeito que perdeu o } \\
\text { controle. } \\
\text { Havia desbunde, } \\
\text { desbundado, desbundar. }\end{array}$ & $\begin{array}{l}\text { Elle a dit que tu avais } \\
\text { perdu la tête }[\ldots . . .] \text { une } \\
\text { zonarde. (p.82) }\end{array}$ \\
\hline
\end{tabular}




\begin{tabular}{|c|c|c|}
\hline & $\begin{array}{l}\text { Foi criado despirocado e } \\
\text { despirocar. Bunda X } \\
\text { Piroca (pênis). } \\
\text { Despirocado è mais forte } \\
\text { que desbundado. }\end{array}$ & \\
\hline $\begin{array}{l}\text { p.107: Quem vê rosto } \\
\text { não vê pesadelo }\end{array}$ & $\begin{array}{l}\text { p.107: Quem vê rosto } \\
\text { não vê pesadelo. } \\
\text { Há um ditado que diz: } \\
\text { quem vê cara não vê } \\
\text { coração. Gustavo Flávio } \\
\text { está fazendo uma } \\
\text { paráfrase desse } \\
\text { aforismo. }\end{array}$ & $\begin{array}{l}\text { A voir son visage, on } \\
\text { ne pouvait deviner ses } \\
\text { cauchemars. (p.88) }\end{array}$ \\
\hline $\begin{array}{l}\text { p.115: Não ponho minha } \\
\text { mão em cumbuca }\end{array}$ & $\begin{array}{l}\text { p.115: Não pondo minha } \\
\text { mão em cumbuca. } \\
\text { |Outro ditado, que diz: } \\
\text { macaco não põe a mão } \\
\text { em cumbuca. Isto è, } \\
\text { macaco não se arrisca } \\
\text { temerariamente. Minolta } \\
\text { gosta de falar dessa } \\
\text { maneira. }\end{array}$ & $\begin{array}{l}\text { Je ne veux pas me } \\
\text { fourrer dans un } \\
\text { guêpier. (p.94) }\end{array}$ \\
\hline p.118: silânimes & $\begin{array}{l}\text { p.118: silânimes } \\
\text { deve ser pusilânimes: } \\
\text { medrosos, covardes. }\end{array}$ & \begin{tabular}{|l} 
Je pris congé de Ceresso \\
par des remerciements \\
timides et serviles. \\
(p.96)
\end{tabular} \\
\hline $\begin{array}{l}\text { p.126: banho de } \\
\text { descarrego }\end{array}$ & \begin{tabular}{|l|} 
p.126: banho de \\
descarrego \\
banho feito com sal \\
grosso para \\
"descarregar", isto é, \\
extrair ou retirar o mau- \\
olhado, ou qualquer outro \\
feitiço. Superstição ligada \\
aos ritos afro-brasileiros.
\end{tabular} & $\begin{array}{l}\text { Avant que je boive lê } \\
\text { liquide, Mariazinha me fit } \\
\text { prendre une douche } \\
\text { libératrice. (p.103) }\end{array}$ \\
\hline p.157: telha de coxa & $\begin{array}{l}\text { p.157: Telha de coxa } \\
\text { Telhas antigas, feitas } \\
\text { sobre a perna, de } \\
\text { formato irregular. }\end{array}$ & \begin{tabular}{||l|} 
Le toi, en tuiles \\
grossières, $n$ 'était \\
probablement pas aussi \\
vieux qu'il le paraissait. \\
(p.127)
\end{tabular} \\
\hline $\begin{array}{l}\text { p.158: relacionados (= } \\
\text { que tem relação } \\
\text { ecológica entre si?) }\end{array}$ & $\begin{array}{l}\text { p.158: relacionados } \\
\text { Arrolados, inventariados, } \\
\text { classificados. }\end{array}$ & $\begin{array}{l}\text { D'après le feuillet, des } \\
\text { milliers d'espèces } \\
\text { animales et végétables }\end{array}$ \\
\hline
\end{tabular}




\begin{tabular}{|c|c|c|}
\hline & & $\begin{array}{l}\text { vivaient dans la région, et } \\
\text { nombre d'entre elles } \\
\text { étaient inventoriées. } \\
(\text { p.127) }\end{array}$ \\
\hline p.161: tilápias & $\begin{array}{l}\text { p.161: tilápias } \\
\text { peixe teleósteo, } \\
\text { actinopterígio, da ordem } \\
\text { dos percomorfos, família } \\
\text { dos ciclìdeos. Peixe de } \\
\text { água doce, comum na } \\
\text { América do Sul, Ásia e } \\
\text { África. Alimenta-se de } \\
\text { vegetais e detritos. } \\
\text { Podem ser criadas em } \\
\text { viveiros. }\end{array}$ & $\begin{array}{l}\text { Les animaux - } \\
\text { chevreaux, lapins, } \\
\text { poulets - étaient mangés } \\
\text { le jour même où on les } \\
\text { abattai ; les poissons- } \\
\text { truites tilapias et carpes } \\
\text { - étaient pris dans les } \\
\text { réservoir et les étangs } \\
\text { respectifs où ils étaient } \\
\text { élévés, le jour même où } \\
\text { on les faisait frire. (p.130) }\end{array}$ \\
\hline $\begin{array}{l}\text { p.172: "surgiram logo } \\
\text { depois do Devoniano": o } \\
\text { problema aqui é que, } \\
\text { segundo aprendi, } \\
\text { Spallanzani vivia no } \\
\text { século XVIII e não podia } \\
\text { falar em devoniano, } \\
\text { palavra surgida em } 1837 \\
\text { quando houve pesquisas } \\
\text { geológicas no distrito de } \\
\text { Devon, na Inglaterra. } \\
\text { Existem duas soluções: } \\
\text { suprimir esta frase ou } \\
\text { transformá-la. }\end{array}$ & $\begin{array}{l}\text { p.172: período } \\
\text { Devoniano. } \\
\text { Vamos suprimir a frase. }\end{array}$ & Suprimiu \\
\hline p.177: hubris & \begin{tabular}{|l|} 
p.177: hubris \\
eu tenho a mania de \\
grafar essa palavra à \\
maneira inglesa. O certo \\
e escrevê-la em grego, já \\
que não existe em \\
português. Em grego, \\
usando nosso alfabeto,
\end{tabular} & $\begin{array}{l}\text { « Hybris, c'est um beau } \\
\text { cliché hellénique. Les } \\
\text { lecteurs adorent ça. » } \\
\text { (p.143) }\end{array}$ \\
\hline
\end{tabular}




\begin{tabular}{|c|c|c|}
\hline & $\begin{array}{l}\text { seria HYBRIS. Vamos } \\
\text { pois escrever hybris. } \\
\text { Significa: insolência, } \\
\text { arrogância, resultante de } \\
\text { excessivo orgulho ou } \\
\text { paixão. }\end{array}$ & \\
\hline $\begin{array}{l}\text { p.189: lei Opiana (deve } \\
\text { existir uma tradução } \\
\text { francesa mas não sei a } \\
\text { que se refere) }\end{array}$ & \begin{tabular}{|l|} 
p.189: Lei Opiana \\
Lei romana, que taxava \\
e/ou proibia o uso de \\
verstuário muito rico. Não \\
sei se foi feita por Catão, \\
creio que sim. Como \\
estou respondendo com \\
muita pressa, somente \\
verei isso depois, caso \\
você ache necessário \\
maiores explicações. \\
\end{tabular} & $\begin{array}{l}\text { Je delirai: la loi Oppia } \\
\text { avait été promulguée } \\
\text { contre elle, Oppius devait } \\
\text { penser à une femme } \\
\text { comme elle quand il avait } \\
\text { critiqué l'extravagance } \\
\text { féminine devant le Sénat } \\
\text { romain. (p.151) }\end{array}$ \\
\hline $\begin{array}{l}\text { p.189: tinturas de Tiro } \\
\text { (mesmo pb) }\end{array}$ & $\begin{array}{l}\text { p.189: Tinturas de Tiro. } \\
\text { Tintura especial de } \\
\text { tecidos, muito apreciada } \\
\text { pelas patrícias romanas. }\end{array}$ & $\begin{array}{l}\text { Elle certainement } \\
\text { posséder un vêtement } \\
\text { pourpre, coloré avec de } \\
\text { la teinture de Tyr, dans } \\
\text { |sa valise en beau cuir (p. } \\
\text { 151) }\end{array}$ \\
\hline $\begin{array}{l}\text { p.223: a prostituta das } \\
\text { provas (aí entendo as } \\
\text { palavras mas não vejo a } \\
\text { que se referem) }\end{array}$ & \begin{tabular}{|l|} 
p.223: A prostituta das \\
provas. \\
Há um velho brocardo, \\
originário se não me \\
engano do direito \\
italiano, que diz que "o \\
testemunho é a prostituta \\
das provas", isto è, o \\
testemunho è uma prova \\
na qual não se pode \\
confiar, por vários \\
motivos.
\end{tabular} & $\begin{array}{l}\text { La Prostituée des } \\
\text { preuves (p.179) }\end{array}$ \\
\hline $\begin{array}{l}\text { p.225: Dec Concílio (= } \\
\text { décimo?) }\end{array}$ & $\begin{array}{l}\text { p.225: Dec. Concílio de } \\
\text { Trento } \\
\text { O Concílio de Trento na } \\
\text { verdade é um serie de } \\
\text { conferências realizadas } \\
\text { pela Igreja Católica entre } \\
1545 \text { e 1563. O nosso è } \\
\text { o décimo. }\end{array}$ & $\begin{array}{l}\text { Encore enfant, il avait } \\
\text { cessé d'aller se } \\
\text { confesser ; il trouvait } \\
\text { humiliant, et dans une } \\
\text { certaine mesure absurde, } \\
\text { de s'agenouiller ainsi } \\
\text { devant un autre homme } \\
\text { pour rapporter ses }\end{array}$ \\
\hline
\end{tabular}




\begin{tabular}{|c|c|c|}
\hline & & $\begin{array}{l}\text { péchés, affirmer son } \\
\text { repentir, et être remis de } \\
\text { ses fautes (v. X } \mathbf{X}^{\mathrm{E}} \text { concile } \\
\text { de Trente, section XIV, } \\
\text { chap. 1à 9) (p.181) }\end{array}$ \\
\hline $\begin{array}{l}\text { p.233: Maraca } \\
\text { (=Maracanã) }\end{array}$ & $\begin{array}{l}\text { p.233: maraca } \\
\text { Abreviatura muito usada } \\
\text { |de Maracanã. }\end{array}$ & $\begin{array}{l}\text { "je pense que je ne suis } \\
\text { pas près de recevoir ma } \\
\text { bonne Mangueira en } \\
\text { |piste, dit Agenor, les } \\
\text { yeux humides. Ni le } \\
\text { Vasco au Maracanã. } \\
\text { (p.187) }\end{array}$ \\
\hline p.233: na passarela & \begin{tabular}{|l|} 
p.233: passarela \\
Pista de desfile de \\
escolas de Samba, na \\
rua Marques de Sapucaí, \\
no centro do Rio de \\
Janeiro. Atualmente \\
existem lá arquibancadas \\
de cimento e camarotes, \\
sendo o local conhecido \\
também como \\
Sambódromo.
\end{tabular} & $\begin{array}{l}\text { "je pense que je ne suis } \\
\text { pas près de recevoir ma } \\
\text { bonne Mangueira en } \\
\text { piste, dit Agenor, les } \\
\text { yeux humides. Ni le } \\
\text { Vasco au Maracanã. } \\
\text { (p.187) }\end{array}$ \\
\hline p.234: bundão & $\begin{array}{l}\text { p.234: bundão } \\
\text { sujeito frouxo }\end{array}$ & $\begin{array}{l}\text { 2) Caïd de la cellule, bien } \\
\text { que soit une lavette. } \\
\text { (p.188) }\end{array}$ \\
\hline $\begin{array}{l}\text { p.241: puseram os } \\
\text { xerifes de cela (= Fora de } \\
\text { cela?) }\end{array}$ & $\begin{array}{l}\text { p.241: Xerife de cela } \\
\text { Bandido que controla, } \\
\text { informalmente, a } \\
\text { |disciplina dentro do } \\
\text { xadrez. Quase sempre } \\
\text { são os mais corajosos e } \\
\text { violentos. }\end{array}$ & $\begin{array}{l}\text { 2) Caïd de la cellule, } \\
\text { bien que soit une lavette. } \\
\text { (p.188) }\end{array}$ \\
\hline p.242: uma teresa & $\begin{array}{l}\text { p.242: teresa } \\
\text { |corda feita com tiras de } \\
\text { lençóis, para fuga de } \\
\text { presos. }\end{array}$ & $\begin{array}{l}\text { Et ils feront une boule } \\
\text { avec de vieilles chemises } \\
\text { ou un drap. (p.194) }\end{array}$ \\
\hline $\begin{array}{l}\text { P,261-262: o último } \\
\text { parágrafo do capítulo (de } \\
\text { "Sei que falo muito etc" a } \\
\text { "...digo, prognóstico, ele } \\
\text { é.") é impossível de } \\
\text { traduzir. Não temos em } \\
\text { francês palavras que } \\
\text { permitam criar um jogo }\end{array}$ & \begin{tabular}{||l|} 
p.261-262: \\
Pernóstico/prognóstico \\
Um problema para você. \\
Não sei como te ajudar a \\
resolvê-lo.
\end{tabular} & $\begin{array}{l}\text { Omissão do último } \\
\text { parágrafo na íntegra } \\
\text { (p.210) }\end{array}$ \\
\hline
\end{tabular}




\begin{tabular}{|c|c|c|}
\hline $\begin{array}{l}\text { de palavras equivalente a } \\
\text { pernóstico/prognóstico. }\end{array}$ & & \\
\hline \multirow{3}{*}{$\begin{array}{l}\text { p.265: eu pensava em } \\
\text { substituir "anteontem" } \\
\text { (Esteve com ela } \\
\text { anteontem) por "ontem": } \\
\text { o cap } 2 \text { (p 263) da parte } \\
\text { V - a maldição, retoma o } \\
\text { relato interrompido p 222, } \\
\text { no final da parte III - O } \\
\text { Refúgio do Pico do } \\
\text { Gavião, assim Suzy deve } \\
\text { ter sido morta no dia } \\
\text { imediatamente anterior à } \\
\text { visita do delegado de } \\
\text { Pereiras. } \\
\end{array}$} & $\begin{array}{l}\text { p.265: ontem } \\
\text { ok }\end{array}$ & $\begin{array}{l}\text { - Vous avez été en sa } \\
\text { compagnie hier, le jour } \\
\text { de sa mort ? (p.212) }\end{array}$ \\
\hline & $\begin{array}{l}\text { p.268: (EMENDA } \\
\text { MINHA) } \\
\text { suprimir "o perito". Quem } \\
\text { sai da sala é um dos } \\
\text { tiras. }\end{array}$ & $\begin{array}{l}\text { Finalement, l'un des } \\
\text { flics sortit du bureau } \\
\text { pour appeler Trindade. } \\
\text { (p.214) }\end{array}$ \\
\hline & $\begin{array}{l}\text { p.275: Corrigir a frase em } \\
\text { alemão para: } \\
\text { Luftsaulenraum, Akustik } \\
\text { und Geigenbau. } \\
\text { (Correção feita pela } \\
\text { tradutora para o alemão) }\end{array}$ & $\begin{array}{l}\text { Le mien, c'est um } \\
\text { guadagnini, de 1780, um } \\
\text { objet précieux. Si je } \\
\text { perdais mon violon, je } \\
\text { pense que j'en mourrais } \\
\text { de dépit, dit Orion. Mais, } \\
\text { pour en revenir à Jazen, } \\
\text { il a écrit un livre, } \\
\text { Luftsäulenraum, } \\
\text { Akustik und } \\
\text { Geigenbau... (p.220) }\end{array}$ \\
\hline p.281: D. Candinha & \begin{tabular}{|l|} 
p.281: D. Candinha \\
Mulher que fala mal da \\
vida alheia. Maledicente.
\end{tabular} & $\begin{array}{l}\text { Reconter des histoires, } \\
\text { n'importe quelle } \\
\text { commère y arrive. } \\
\text { (p.225) }\end{array}$ \\
\hline p.314: um CTI & $\begin{array}{l}\text { p.314: CTI } \\
\text { |Centro de Tratamento } \\
\text { Intensivo ou UPI, } \\
\text { Unidade de Tratamento } \\
\text { Intensivo. }\end{array}$ & $\begin{array}{l}\text { Em plus, il lui a tiré trois } \\
\text { Même s'il avait fait ça à } \\
\text { l'intérieur d'une unité de } \\
\text { soins intensifs, avec les } \\
\text { médecins autour et prêts } \\
\text { |à intervenir, Agenor était } \\
\text { baisé. La femme a eu de } \\
\text { la chance. (p.250) }\end{array}$ \\
\hline
\end{tabular}




\begin{tabular}{|c|c|c|}
\hline $\begin{array}{l}\text { p.315: E os moradores } \\
\text { de qq forma não } \\
\text { transportariam etc }\end{array}$ & $\begin{array}{l}\text { p.315: Os moradores de } \\
\text { qualquer forma, etc. } \\
\text { Pode suprimir a frase. }\end{array}$ & $\begin{array}{l}\text { D'après Bráulio, le couple } \\
\text { devait s'apprêter à entrer } \\
\text { dans le motel; cet endroit } \\
\text { |ne se prêtait pas à ce } \\
\text { qu'on s'y débarrasse de } \\
\text { personnes tuées } \\
\text { ailleurs.(Suprimiu) Le } \\
\text { couple devait s'apprêter } \\
\text { à entrer, et non à sortir; } \\
\text { (p.251) }\end{array}$ \\
\hline $\begin{array}{l}\text { p.329: os presídios do } \\
\text { Rio de Janeiro (= os } \\
\text { cárceres?) }\end{array}$ & $\begin{array}{l}\text { p.329: Presídios } \\
\text { Estabelecimentos penais } \\
\text { onde os condenados } \\
\text { |ficam detidos ou } \\
\text { reclusos. }\end{array}$ & $\begin{array}{l}\text { Le milliardaire Eugênio } \\
\text { Delarme avait engagé le } \\
\text { tueur à gages Agenor da } \\
\text { Silva, appartenant à la } \\
\text { bande de truands qui } \\
\text { contrôlait les prisons de } \\
\text { Rio de Janeiro (p.263) }\end{array}$ \\
\hline \multicolumn{3}{|l|}{ Outros problemas: } \\
\hline $\begin{array}{l}\text { O nome do bailarino } \\
\text { Sílvio está escrito muitas } \\
\text { vezes sem acento no } \\
\text { primeiro i, vou adotar } \\
\text { sistematicamente a grafia } \\
\text { com acento. }\end{array}$ & \multirow[t]{2}{*}{$\begin{array}{l}\text { Pode uniformizar o Sílvio } \\
\text { e o Agenor, como achar } \\
\text { melhor. }\end{array}$} & $\begin{array}{l}\text { Je pris l'adresse de } \\
\text { Roma et Sílvio; (p.243) }\end{array}$ \\
\hline $\begin{array}{l}\text { O nome do falso } \\
\text { assassino é às vezes } \\
\text { Agenor da Silva, outras } \\
\text { vezes Agenor Silva, sem } \\
\text { da. Se se trata de um } \\
\text { erro involuntário dos } \\
\text { tipógrafos, posso } \\
\text { escrevê-lo sempre com } \\
\text { da. }\end{array}$ & & $\begin{array}{l}\text { Le milliardaire Eugênio } \\
\text { Delarme avait engagé le } \\
\text { tueur à gages Agenor da } \\
\text { Silva (p.263) }\end{array}$ \\
\hline $\begin{array}{l}\text { A Sociedade Brasileira } \\
\text { de Proteção ao Anfíbio a } \\
\text { que pertence Ceresso, } \\
\text { aparece uma só vez } \\
\text { denominada de } \\
\text { Associação etc (p.84). Se } \\
\text { não é voluntário, vou } \\
\text { restabelecer Sociedade. }\end{array}$ & & $\begin{array}{l}\text { Ils me donnèrent le } \\
\text { numéro de téléphone } \\
\text { d'une autre maison et, } \\
\text { après plusieurs appels, je } \\
\text { parvins À obtenir celui } \\
\text { d'une Société } \\
\text { brésilienne de } \\
\text { protection des }\end{array}$ \\
\hline
\end{tabular}




\begin{tabular}{||l||l||l||}
\hline \multicolumn{1}{|c||}{} & amphibiens. (p.70) \\
\hline as.258: tentei reproduzir & p.259: na nota de pé-de- & Jane Eyre, Brontë \\
romances não franceses & página: & (p.208) \\
que você cita tais como & Preconceita, Orgulho e & \\
foram traduzidas nas & Colocar Jane Eyre, & \\
edições francesas, mas a a & Bronte; & \\
citação de Austen & Foi esse erro que eu lhe & \\
(Orgulho e Preconceito) & mencionei quando & \\
não coincide & estivemos juntos em & \\
absolutamente com o & Paris. & \\
que encontrei e me & & \\
perguntei se se tratava & & \\
mesmo deste romance & & \\
ou doutro. Talvez fora & & \\
esse o erro de que você & & \\
me falou quando nos & & \\
encontrámos em Paris & & \\
em março, mas & & \\
infelizmente eu não me & & \\
lembro. & & \\
\hline
\end{tabular}

Embora não se pretenda neste estudo esgotar as possibilidades de análise, algumas das soluções merecem desde já comentários mais detalhados.

Para o termo "hiponga", por exemplo, houve solução satisfatória, porém os franceses têm uma gíria para os hippies: "babacool", atribuída aos hippies da geração de 68. Tivesse o tradutor utilizado esse termo, sua opção tenderia a uma solução mais domesticadora. Dessa forma, o "à la mode hippie" torna-se uma solução bastante neutra.

Perde-se na opção do termo "boule" para "teresa", que de fato é uma corda, assim como se perde o jogo com o provérbio "Quem vê cara, não vê coração", em "Quem vê rosto não vê pesadelo", na solução dada pelo tradutor "A voir son visage, on ne pouvait deviner ses cauchemars". Contudo, "não ponho minha mão em cumbuca", foi bem solucionado por "Je ne veux pas me fourrer dans un guêpier".

Pode-se igualmente relacionar algumas eufemizações como "il a perdu la tête" para "ele está despirocado" e "pusilânime" por "timide".

A solução para o "banho de descarrego", apesar de bastante criativa: "douche libératrice", não garante a comprrensão do leitor francês. 
Talvez encorajado pelas sugestões em suprimir alguns trechos de sua lista, o tradutor tenha optado muitas vezes pela omissão, como na frase "Livro é alto astral", que foi retirada por sua dificuldade em encontrar correspondente para "alto astral".

As omissões e mal-entendidos, no entanto, não comprometem o entendimento dos períodos. Vale salientar, entretanto, que alguns itens listados pelo tradutor dizem respeito ao seu conhecimento geral, seu escopo cultural, e revelam a necessidade de maior pesquisa de sua parte.

Para contrastar com a primeira lista aqui apresentada, elegeu-se parte da correspondência relativa à tradução de Agosto, muito mais específica e plena de referências históricas.

\begin{tabular}{|c|c|c|c|}
\hline Texto original & $\begin{array}{l}\text { Carta de Philippe } \\
\text { Billé a Rubem } \\
\text { Fonseca } \\
\text { (11.11.1991) }\end{array}$ & $\begin{array}{l}\text { Carta de Rubem } \\
\text { Fonseca a Philippe } \\
\text { Billé (11.11.1991) }\end{array}$ & Texto traduzido \\
\hline $\begin{array}{l}\text { Em julho, a canalha } \\
\text { udenista, sempre com } \\
\text { propósitos golpistas... } \\
\text { (p.09) }\end{array}$ & $\begin{array}{l}\text { UDN: (suponho que é } \\
\text { União Democrática } \\
\text { Nacional) }\end{array}$ & $\begin{array}{l}\text { UDN. Sim, é o partido } \\
\text { político União } \\
\text { Democrática Nacional }\end{array}$ & $\begin{array}{l}\text { En juillet, la canaille } \\
\text { de l'UDN }{ }^{1} \text { avait } \\
\text { inventé, toujours afin } \\
\text { de justifier un coup } \\
\text { d'Etat... (p.11) } \\
\text { 1. UDN: União } \\
\text { Democrática } \\
\text { Nacional. } \\
\text { (N.d.T) }\end{array}$ \\
\hline $\begin{array}{l}\text { "Ouvindo o Lacerda, } \\
\text { doutor? O mar de lama } \\
\text { cada vez aumenta mais. } \\
\text { Viu a palavra que o } \\
\text { homem inventou? } \\
\text { Kakistocracia - } \\
\text { governo pelo piores } \\
\text { elementos da } \\
\text { sociedade..." (p.10) }\end{array}$ & $\begin{array}{l}\text { p.10: kakistocracia } \\
\text { (vou deixar } \\
\text { kakistocratie, mas } \\
\text { sabe qual é a } \\
\text { etimologia da } \\
\text { palavra?) }\end{array}$ & $\begin{array}{l}\text { p.10 - kakistocracia. A } \\
\text { palavra é grega, } \\
\text { composta de kákisto, } \\
\text { superlativo de kákos, } \\
\text { que significa mau + } \\
\text { cracia, ou seja, } \\
\text { governo das piores } \\
\text { pessoas. O termo é } \\
\text { usado na Inglaterra e } \\
\text { nos USA e consta dos } \\
\text { principais dicionários }\end{array}$ & $\begin{array}{l}\text { Vous écoutez } \\
\text { Lacerda, commisaire. } \\
\text { L'océan de boue } \\
\text { grossit sans arrêt. } \\
\text { Vous avez entendu le } \\
\text { mot qu'il a inventé? } \\
\text { La kakistocratie - le } \\
\text { gouvernement par les } \\
\text { pires éléments de la } \\
\text { société... (p.12) }\end{array}$ \\
\hline
\end{tabular}




\begin{tabular}{|c|c|c|c|}
\hline & & $\begin{array}{l}\text { da língua inglesa. } \\
\text { Provavelmente existe } \\
\text { também em algum } \\
\text { dicionário de língua } \\
\text { francesa. Os } \\
\text { dicionários de } \\
\text { português que possuo } \\
\text { (Aurélio, Caldas } \\
\text { Aulete, Candido } \\
\text { Figueiredo, } \\
\text { Melhoramentos) não } \\
\text { incluem essa palavra. } \\
\text { Mas ela foi usada pelo } \\
\text { jornalista Carlos } \\
\text { Lacerda, em artigos } \\
\text { escritos no jornal } \\
\text { TRIBUNA DA } \\
\text { IMPRENSA. }\end{array}$ & \\
\hline $\begin{array}{l}\text { Como sempre fazia } \\
\text { quando estava nervoso, } \\
\text { rodou no dedo o anel } \\
\text { de formatura (...) (p.21) }\end{array}$ & $\begin{array}{l}\text { p.21: anel de } \\
\text { formatura }\end{array}$ & $\begin{array}{l}\text { p.21 - anel de } \\
\text { formatura. É o mesmo } \\
\text { que anel de grau, que } \\
\text { os indivíduos que se } \\
\text { "formavam", isto é, } \\
\text { completavam um } \\
\text { curso superior, } \\
\text { usavam. O anel dos } \\
\text { "formados" em direito } \\
\text { é como aquele que } \\
\text { descrevi no livro; os } \\
\text { que se formavam em } \\
\text { medicina usavam um } \\
\text { anel de pedra verde, } \\
\text { etc. Hoje são poucos } \\
\text { os que ostentam um } \\
\text { desses anéis, sendo o } \\
\text { seu uso considerado } \\
\text { pouco elegante. }\end{array}$ & $\begin{array}{l}\text { Comme chaque fois } \\
\text { qu'il était indécis et } \\
\text { nerveux, il fit tourner } \\
\text { sur son doigt sa } \\
\text { bague honorifique. } \\
\text { (p.22) }\end{array}$ \\
\hline $\begin{array}{l}\text { “É sobre a licença da } \\
\text { Cexim. (p.21) }\end{array}$ & $\begin{array}{l}\text { p.21 e sq: } \underline{\text { Cexim }} \\
\text { (deve ser Caixa de } \\
\text { alguma coisa...) }\end{array}$ & $\begin{array}{l}\text { p.21 - CEXIM. } \\
\text { Carteira de } \\
\text { Exportação e } \\
\text { Importação, uma } \\
\text { seção do Banco do } \\
\text { Brasil que controlava } \\
\text { as exportações e } \\
\text { importações no país } \\
\text { inteiro. }\end{array}$ & $\begin{array}{l}\text { C'est au sujet de la } \\
\text { licence de la Cexim1. } \\
\text { (p.22) } \\
\text { 1.Cexim: Carteira de } \\
\text { Exportação e } \\
\text { Importação: sorte de } \\
\text { caisse pour l'import- } \\
\text { export. (N.d.T) }\end{array}$ \\
\hline O filme é O diabo ri por & p.24: filme o diabo ri & p.24-O diabo ri por & Le film s'appelle Plus \\
\hline
\end{tabular}




\begin{tabular}{|c|c|c|c|}
\hline último. (p. 24) & $\begin{array}{l}\text { por último: de quem é } \\
\text { esse filme? (para eu } \\
\text { ver se encontro o } \\
\text { título francês já } \\
\text { existente) }\end{array}$ & $\begin{array}{l}\text { último. Um filme } \\
\text { americano produzido } \\
\text { em 1953, com o título } \\
\text { original de BEAT THE } \\
D E V I L \text {, dirigido por } \\
\text { John Huston, com } \\
\text { Humphrey Bogart, } \\
\text { Jennifer Jones, Gina } \\
\text { Lollobrigida. } \\
\text { Curiosidade: o roteiro, } \\
\text { baseado no romance } \\
\text { de James Helvick, } \\
\text { pseudônimo de Claud } \\
\text { Cockburn, é do } \\
\text { Truman Capote. É um } \\
\text { dos mais fracos filmes } \\
\text { do John Huston. } \\
\text { Bogart disse que o } \\
\text { filme era uma porcaria } \\
\text { e que somente os } \\
\text { farsantes gostavam } \\
\text { dele. }\end{array}$ & $\begin{array}{l}\text { fort que le diable. } \\
\text { (p.26) }\end{array}$ \\
\hline $\begin{array}{l}\text { Mattos ouvira falar no } \\
\text { influente senador do } \\
\text { PSD. (p.28) }\end{array}$ & $\begin{array}{l}\text { PSD: (Partido Social } \\
\text { Democrata?) }\end{array}$ & $\begin{array}{l}\text { PSD - Sim, Partido } \\
\text { Social Democrático. }\end{array}$ & $\begin{array}{l}\text { Mattos avait entendu } \\
\text { parler de cet influent } \\
\text { sénateur du } \text { PSD }^{1} \text {. } \\
\text { (p.29) } \\
\text { 1. PSD: Partido Social } \\
\text { Democrático. (N.d.T) }\end{array}$ \\
\hline $\begin{array}{l}\text { (...) face trapezoidal, } \\
\text { perfil ortognático, } \\
\text { parietais desviados, } \\
\text { crânio em quilha, } \\
\text { constituição pícnica } \\
\text { (...) (p.35) }\end{array}$ & $\begin{array}{l}\text { p.35: constituição } \\
\text { pícnica: (conhece a } \\
\text { etimologia ou um } \\
\text { sinônimo?) }\end{array}$ & $\begin{array}{l}\text { p.35 - Constituição } \\
\text { Pícnica. Um psiquiatra } \\
\text { alemão chamado } \\
\text { Krestschmer } \\
\text { (1888/1964), inventou } \\
\text { uma tipologia muito } \\
\text { em moda até os anos } \\
\text { cinqüenta, que } \\
\text { estabelecia uma } \\
\text { correspondência entre } \\
\text { constituição física e }\end{array}$ & $\begin{array}{l}\text { (...) face trapézoïdale, } \\
\text { profil orthognathe, } \\
\text { pariétaux dévies, } \\
\text { crâne en quille, } \\
\text { constituition } \\
\text { pycnique }(. . .)(\text { (p.35) }\end{array}$ \\
\hline
\end{tabular}




\begin{tabular}{|c|c|c|c|}
\hline & & $\begin{array}{l}\text { temperamento. Os } \\
\text { tipos eram atlético, } \\
\text { picnico e } \\
\text { leptosomático. Ao } \\
\text { pícnco, de tipo } \\
\text { corporal baixo, } \\
\text { troncudo, membros } \\
\text { curtos, correspondia o } \\
\text { temperamento } \\
\text { ciclotímico, que se } \\
\text { caracteriza, segundo } \\
\text { o alemão, por } \\
\text { variações cíclicas } \\
\text { pendulares entre } \\
\text { alegria e tristeza. Não } \\
\text { lhe é dada, hoje, } \\
\text { importância científica, } \\
\text { mas lembro-me de ter } \\
\text { lido o Krestschmer } \\
\text { com algum prazer } \\
\text { literário. }\end{array}$ & \\
\hline $\begin{array}{l}\text { "Aquele colarinho de } \\
\text { dois dedos e um } \\
\text { Steinhager, para lhe } \\
\text { dar espírito," disse } \\
\text { Emílio. (p.52) }\end{array}$ & $\begin{array}{l}\text { p.52: colarinho de dois } \\
\text { dedos: tipo de } \\
\text { cerveja? } \\
\text { p.52: Steinhager: que } \\
\text { tipo de bebida é? }\end{array}$ & $\begin{array}{l}\text { p.52 - Steinhager. } \\
\text { Aguardente feita com } \\
\text { bagaço de uva. }\end{array}$ & $\begin{array}{l}\text { - En même temps que } \\
\text { ce faux-col, donne- } \\
\text { moi une eau-de-vie } \\
\text { Steinhager, pour lui } \\
\text { donner de l'esprit", dit } \\
\text { Emílio. (p.51) }\end{array}$ \\
\hline $\begin{array}{l}\text { Saltou na porta do } \\
\text { restaurante SAPS. } \\
\text { (p.73) }\end{array}$ & p.73: SAPS & $\begin{array}{l}\text { p.73 - SAPS. Serviço } \\
\text { de Alimentação da } \\
\text { Previdência Social } \\
\text { (Estou citando de } \\
\text { memória) Restaurante } \\
\text { popular, mantido pelo } \\
\text { governo, que servia } \\
\text { refeições de baixo } \\
\text { custo. }\end{array}$ & 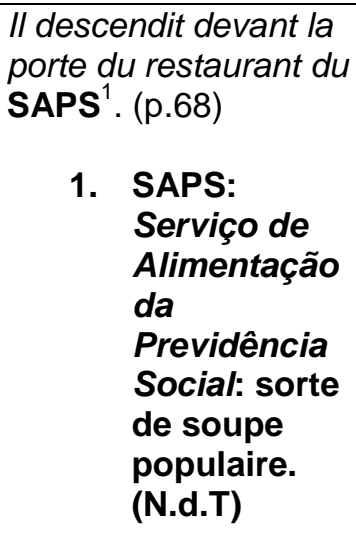 \\
\hline $\begin{array}{l}\text { Os congregados } \\
\text { estavam pissudos com } \\
\text { a reportagem. (p.78) }\end{array}$ & p.78: pissudo & $\begin{array}{l}\text { p.78 - Pissudos. O } \\
\text { certo seria PIÇUDOS, } \\
\text { de piça, palavra chula } \\
\text { que designa o pênis. } \\
\text { Por falar em enganos } \\
\text { espero que você não } \\
\text { esteja usando a } \\
\text { primeira edição do } \\
\text { Agosto, tem erros de } \\
\text { datas e grafia errada } \\
\text { de certas palavras. }\end{array}$ & $\begin{array}{l}\text { Les membres de la } \\
\text { congrégation étaient } \\
\text { en colère à cause de } \\
\text { ce reportage. (p.73) }\end{array}$ \\
\hline
\end{tabular}




\begin{tabular}{|c|c|c|c|}
\hline & & $\begin{array}{l}\text { Por favor, se estiver } \\
\text { usando a primeira } \\
\text { edição me escreva } \\
\text { para eu lhe dar as } \\
\text { correções importantes } \\
\text { que devem ser feitas } \\
\text { no texto original. }\end{array}$ & \\
\hline $\begin{array}{l}\text { O filho nunca quis saber } \\
\text { dos anauês dos verdes } \\
\text { (...) (p.79) }\end{array}$ & p.79: anauês & $\begin{array}{l}\text { p.79 - Anauês. O } \\
\text { gesto de saudação } \\
\text { levantando o braço a } \\
\text { maneira fascista e } \\
\text { nazista, usado pelos } \\
\text { membros da Ação } \\
\text { Integralista Brasileira, } \\
\text { um partido político de } \\
\text { direita chefiado por } \\
\text { Plínio Salgado. }\end{array}$ & $\begin{array}{l}\text { Les fils n'a jamais rien } \\
\text { voulu savoir des } \\
\text { "verts" (...) (p.74) }\end{array}$ \\
\hline $\begin{array}{l}\text { "Ele precisava trazer } \\
\text { seu catamito?" (p.92) }\end{array}$ & p.92: catamito & $\begin{array}{l}\text { p.92 - Catamito. O } \\
\text { Aurélio não registra } \\
\text { mas está no Caldas } \\
\text { Aulete e no dicionário } \\
\text { da Melhoramentos. } \\
\text { Homossexual jovem. } \\
\text { Do latim catamitus, } \\
\text { vindo do etrusco } \\
\text { catmite e do grego } \\
\text { ganymédes. Não sei } \\
\text { como não existe essa } \\
\text { palavra no francês. }\end{array}$ & $\begin{array}{l}\text { - Il avait besoin } \\
\text { d'amener son } \\
\text { mignon? (p.84) }\end{array}$ \\
\hline $\begin{array}{l}\text { Não dá tempo para os } \\
\text { funcionários rubricarem } \\
\text { as cédulas fabricadas } \\
\text { pelas guitarras da Casa } \\
\text { da Moeda, American } \\
\text { Bar e Thomas de la } \\
\text { Rue. (p. 93) }\end{array}$ & $\begin{array}{l}\text { p.93: Thomas de la } \\
\text { rue: nome de algum } \\
\text { instituto? }\end{array}$ & $\begin{array}{l}\text { p.93 - Thomas de La } \\
\text { Rue. Firma inglesa } \\
\text { que fabricava o papel } \\
\text { moeda no Brasil na } \\
\text { época. }\end{array}$ & $\begin{array}{l}\text { Les fonctionnaires } \\
\text { n'ont pas le temps de } \\
\text { parapher toute la } \\
\text { monnaie qui sort des } \\
\text { planches à billes de la } \\
\text { Maison de la monnaie, } \\
\text { de l'American Bank } \\
\text { Note et de l'institut } \\
\text { Thomas de la Rue. } \\
\text { (p.85) }\end{array}$ \\
\hline $\begin{array}{l}\text { Salete pediu um } \\
\text { churrasco misto com } \\
\text { farofa e guaraná. } \\
\text { (p.103) }\end{array}$ & $\begin{array}{l}\text { p.103: guaraná: suco } \\
\text { de fruta? }\end{array}$ & $\begin{array}{l}\text { p.103 - Guaraná. } \\
\text { Arbusto nativo cuja } \\
\text { semente é usada de } \\
\text { várias maneiras; em } \\
\text { refrigerantes } \\
\text { industrializados muito } \\
\text { populares em todo o } \\
\text { país, ou então em pó, } \\
\text { dissolvido depois na } \\
\text { água, maneira em que } \\
\text { ele é consumido pelos }\end{array}$ & $\begin{array}{l}\text { Salete commanda une } \\
\text { viande grillée, avec } \\
\text { une garniture et un } \\
\text { verre de guaraná }{ }^{1} \text {. } \\
\text { (p.93) } \\
\begin{array}{l}\text { 1. Boisson tirée de la } \\
\text { plante du même } \\
\text { nom. (N.d.T) }\end{array}\end{array}$ \\
\hline
\end{tabular}




\begin{tabular}{|c|c|c|c|}
\hline & & \begin{tabular}{|l|} 
fanáticos da \\
alimentação natural \\
que acreditam, como \\
os índios maues que o \\
usaram pela primeira \\
vez, que a substância \\
tem fortes poderes \\
medicinais.
\end{tabular} & \\
\hline $\begin{array}{l}\text { Freitas imaginou o } \\
\text { sucesso das frases } \\
\text { candentes de Lacerda } \\
\text { na grande reunião do } \\
\text { Clube da Lanterna, } \\
\text { marcada para aquela } \\
\text { noite na ABI.(p.156) }\end{array}$ & p.156: $\underline{A B \mid}$ & $\begin{array}{l}\text { p.156 - ABI. } \\
\text { Associação Brasileira } \\
\text { de Imprensa. }\end{array}$ & $\begin{array}{l}\text { Freitas imagina le } \\
\text { succès qu'auraient les } \\
\text { propos enflammés de } \\
\text { Lacerda à la grande } \\
\text { réunion du Club de la } \\
\text { Lanterne, prévue pour } \\
\text { ce soir-là, dans le } \\
\text { locaux de } \\
\text { l'Association } \\
\text { brésilienne de } \\
\text { presse (...) (p.139) }\end{array}$ \\
\hline $\begin{array}{l}\text { Sei. Uma das minhas } \\
\text { cambonas me disse. } \\
\text { Fiquei muito triste. Ele } \\
\text { era uma boa pessoa. } \\
\text { (p.205) }\end{array}$ & p.205: cambona & $\begin{array}{l}\text { p.205 - Cambona. } \\
\text { Ajudante de pai-de- } \\
\text { santo; este, sacerdote } \\
\text { das macumbas e } \\
\text { candomblés, cultos } \\
\text { fetichistas afro- } \\
\text { brasileiros. }\end{array}$ & $\begin{array}{l}\text { - Oui. Une de mes } \\
\text { assistantes me l'a dit. } \\
\text { Ça m'a fait beaucoup } \\
\text { de peine. Il était gentil. }\end{array}$ \\
\hline $\begin{array}{l}\text { O investigador que } \\
\text { comanda a guarnição é } \\
\text { um seboso. Diz que } \\
\text { fizeram um flagrante. } \\
\text { (p.208) }\end{array}$ & p.208: seboso (ruim?) & $\begin{array}{l}\text { p.208 - Seboso. No } \\
\text { caso, o mesmo que } \\
\text { metido a sebo, isto é, } \\
\text { acreditando-se } \\
\text { importante e vaidoso } \\
\text { por isso. }\end{array}$ & $\begin{array}{l}\text { - L'inspecteur qui } \\
\text { commandait la } \\
\text { patrouille se prend au } \\
\text { sérieux.. Il dit que } \\
\text { c'est un flagrant délit. }\end{array}$ \\
\hline $\begin{array}{l}\text { (...) Arinos declarou que } \\
\text { a polícia procura elidir a } \\
\text { validade das provas } \\
\text { através de um processo } \\
\text { de 'desmilingüização'. } \\
\text { (p.213) }\end{array}$ & $\begin{array}{l}\text { p.213: } \\
\text { desmilinguização } \\
\begin{array}{l}\text { (como é formada a } \\
\text { palavra?) }\end{array}\end{array}$ & $\begin{array}{l}\text { p.213 - } \\
\text { Desmilingüização. } \\
\text { Gíria significando } \\
\text { enfraquecimento, } \\
\text { debilitação, perda do } \\
\text { vigor. Creio que a } \\
\text { origem é } \\
\text { onomatopéica. }\end{array}$ & $\begin{array}{l}\text { Arinos a mis en cause } \\
\text { l'enquête policière et a } \\
\text { prétendu que la police } \\
\text { essayait de discréditer } \\
\text { les preuves } \\
\text { existantes. OMISsÃo } \\
\text { (p.187) }\end{array}$ \\
\hline $\begin{array}{l}\text { "É. Mas os dois } \\
\text { trabalham como } \\
\text { apontadores de bicho } \\
\text { para o seu llídio, } \\
\text { quando a punga está } \\
\text { ruim." (p.221) }\end{array}$ & $\begin{array}{l}\text { p.221 e outras: } \\
\text { apontadores do bicho }\end{array}$ & $\begin{array}{l}\text { p.221 - Apontadores } \\
\text { de bicho. Pessoas } \\
\text { que, em mesas nas } \\
\text { calçadas, anotam a } \\
\text { apostas feitas no jogo } \\
\text { do bicho, um jogo feito } \\
\text { em números. Hoje há } \\
\text { mulheres também } \\
\text { anotando o jogo, coisa } \\
\text { inimaginável nos anos } \\
\text { 1950. } \\
\end{array}$ & $\begin{array}{l}\text { - Oui. Mais ils } \\
\text { travaillent tous deux } \\
\text { comme vendeurs du } \\
\text { bicho, pour monsieur } \\
\text { Ilídio, quand la fauche } \\
\text { est maigre. (p.195) }\end{array}$ \\
\hline
\end{tabular}




\begin{tabular}{|c|c|c|c|}
\hline $\begin{array}{l}\text { Vamos ver como os } \\
\text { jornais do Chatô se } \\
\text { comportam daqui pra } \\
\text { frente. (p.262) }\end{array}$ & $\begin{array}{l}\text { p.262: os jornais do } \\
\text { Chatô }\end{array}$ & $\begin{array}{l}\text { p.262 - Os jornais do } \\
\text { Chatô. Chatô era o } \\
\text { apelido pelo qual era } \\
\text { conhecido por todos } \\
\text { os brasileiros o } \\
\text { jornalista Assis } \\
\text { Chateaubriand } \\
\text { Bandeira de Mello } \\
\text { (1891/1968), também } \\
\text { político, empresário, } \\
\text { embaixador do Brasil } \\
\text { na Inglaterra no } \\
\text { governo Kubitscheck, } \\
\text { membro da Academia } \\
\text { Brasileira de Letras, } \\
\text { fundador do Museu de } \\
\text { Arte de São Paulo, } \\
\text { etc. Uma } \\
\text { personalidade } \\
\text { interessante. Um } \\
\text { amigo meu está } \\
\text { escrevendo a } \\
\text { biografia dele. Na } \\
\text { época do livro era um } \\
\text { dos homens mais } \\
\text { importantes do Brasil. }\end{array}$ & $\begin{array}{l}\text { - On va voir comment } \\
\text { les journaux de } \\
\text { Chateaubriand se } \\
\text { comportent, } \\
\text { dorénavant. (p.230) }\end{array}$ \\
\hline $\begin{array}{l}\text { "Eu tenho que ir. } \\
\text { Coloquei bastante } \\
\text { dinheiro na tua conta do } \\
\text { Boavista." (p.281) }\end{array}$ & $\begin{array}{l}\text { p.281: tua conta do } \\
\text { Boavista (nome de um } \\
\text { banco?) }\end{array}$ & $\begin{array}{l}\text { p.281 - Boavista. } \\
\text { Nome de um banco, } \\
\text { que existe até hoje. }\end{array}$ & $\begin{array}{l}\text { - Il faut que j'y aille. } \\
\text { J'ai versé pas mal } \\
\text { d'argent sur ton } \\
\text { compte à la banque } \\
\text { Boavista. (p.249) }\end{array}$ \\
\hline $\begin{array}{l}\text { Então vou lhe dar o } \\
\text { serviço, mesmo porque } \\
\text { esse Pedro lomagno é } \\
\text { um sujeito rico metido a } \\
\text { besta. (p.293) }\end{array}$ & p.293: metido a besta & $\begin{array}{l}\text { p.293 - Metido a } \\
\text { besta. Pretensioso, } \\
\text { pedante, presunçoso. } \\
\text { Mais ou menos o } \\
\text { mesmo que seboso } \\
\text { (Ver acima). }\end{array}$ & $\begin{array}{l}\text { Alors je vais vous } \\
\text { aider, surtout que ce } \\
\text { Pedro Lomagno est } \\
\text { un richard } \\
\text { prétentieux. (p.259) }\end{array}$ \\
\hline $\begin{array}{l}\text { Eu desconfio que ele } \\
\text { fazia meia com o } \\
\text { Chicão. (p.294) }\end{array}$ & p.294: fazia meia & $\begin{array}{l}\text { p.294 - Alternância de } \\
\text { posição na realização } \\
\text { do coito anal por } \\
\text { homossexuais, ora } \\
\text { passivamente, ora } \\
\text { ativamente. }\end{array}$ & $\begin{array}{l}\text { Je crois bien qu'il } \\
\text { s'envoyait en l'air } \\
\text { avec Chicão. }\end{array}$ \\
\hline $\begin{array}{l}\text { Desde o princípio ele } \\
\text { não esperava um apoio }\end{array}$ & $\begin{array}{l}\text { p. 319: comborça } \\
\text { (motim?) }\end{array}$ & $\begin{array}{l}\text { p.319 - Comborça. } \\
\text { Comborça no seu }\end{array}$ & $\begin{array}{l}\text { Dès le début, il ne } \\
\text { s'était pas attendu à }\end{array}$ \\
\hline
\end{tabular}




\begin{tabular}{|c|c|c|}
\hline $\begin{array}{l}\text { sólido para lutar; } \\
\text { conhecia a natureza } \\
\text { humana, participara em } \\
\text { sua carreira política, de } \\
\text { conchavos, revoltas, } \\
\text { comborças, golpes, } \\
\text { revoluções. (p.319) }\end{array}$ & $\begin{array}{l}\text { significado vernacular } \\
\text { significa "aquela que é } \\
\text { amante de um } \\
\text { homem, em relação à } \\
\text { mulher ou a outra } \\
\text { amante do homem." } \\
\text { Durante algum tempo } \\
\text { a palavra "comborça", } \\
\text { como gíria, significou } \\
\text { "infâmia, patifaria". } \\
\text { Assim como } \\
\text { aconteceu com o } \\
\text { termo "sacanagem" } \\
\text { que atualmente quer } \\
\text { dizer entre outras } \\
\text { coisas, zombaria, } \\
\text { malandragem, vileza } \\
\text { etc. e antes } \\
\text { significava apenas } \\
\text { devassidão e } \\
\text { libidinagem. Hoje } \\
\text { ninguém mais faz uso } \\
\text { da palavra comborça, } \\
\text { no sentido usado no } \\
\text { livro, e antes não } \\
\text { eram muitos os que o } \\
\text { faziam. Nunca foi } \\
\text { dicionarizada, como } \\
\text { giria. Sua situação é } \\
\text { pior ainda que a do } \\
\text { desmilingüir, que o } \\
\text { Aurélio registra. Eu } \\
\text { pretendo numa edição } \\
\text { futura tirar a palavra } \\
\text { comborça do livro. } \\
\text { Você pode tirá-la da } \\
\text { tradução. }\end{array}$ & $\begin{array}{l}\text { recevoir beaucoup de } \\
\text { soutien pour se battre; } \\
\text { il connaissait la nature } \\
\text { humaine, ayant } \\
\text { participé, tout au long } \\
\text { de sa carrière } \\
\text { politique, à des } \\
\text { complots, des } \\
\text { révoltes, des } \\
\text { émeutes, des coups } \\
\text { d'État, des } \\
\text { révoulutions. (p.280) }\end{array}$ \\
\hline
\end{tabular}

Em razão das referências históricas e da utilização de siglas e serviços governamentais específicos, em vários momentos o tradutor valeu-se do recurso explicativo "Nota do tradutor" para esclarecer o leitor. "Chateaubriand" mereceria uma nota esclarecedora, para não haver ambigüidades. Observe-se que Billé utilizou o mesmo recurso quanto ao termo "guaraná", tornando sua tradução mais estrangeirizadora, embora fosse mais apropriado utilizar na explicação "bebida extraída da fruta da planta do mesmo nome". 
Percebe-se novamente a ocorrência de eufemização na opção de "Les membres de la congrégation étaient en colère à cause de ce reportage" para "Os congregados estavam pissudos com a reportagem."

Mais uma vez reforça-se a sugestão de que o conjunto da correspondência, embora desfalcado de inúmeras peças, merece consideração especial em futuros trabalhos a este relacionados. A apresentação de alguns fragmentos neste estudo visa complementar algumas das reflexões acerca tanto das dificuldades em se traduzir Rubem Fonseca para a língua francesa como das estratégias editoriais relativas à sua publicação na França.

As correspondências foram esclarecedoras em alguns pontos. Se é verdade que Rubem Fonseca se mostra avesso à mídia, o mesmo não se pode dizer da sua relação com os tradutores que o solicitam. Atencioso e minucioso, o autor brasileiro, além de esclarecer as dúvidas de Philippe Billé, organiza e fornece verdadeiros glossários a seus tradutores.

Embora em suas cartas Fonseca enfatize a preferência pelo uso de aspas no lugar do travessão, nenhum dos romances de Rubem Fonseca obedeceu a essa pontuação.

O fator mais importante diz respeito aos títulos dos romances $A$ grande arte e Agosto.

Rubem Fonseca comenta a modificação para Du grand art, que traz uma ambigüidade e talvez "vantagens mercadológicas". Em um primeiro momento, o DU seria lido em francês como artigo partitivo: C'est du grand art! Porém, o DU pode também, em uma segunda instância, ser lido como preposição indicando $D u$ grand art et d'autres moins grands... Assim como há no romance a arte do "percor", da utilização da faca, e a arte da investigação, da astúcia.

Questionado sobre a mudança no título de Agosto, Philippe Billé comentou apenas que Rubem Fonseca compreendeu não ser ele o responsável por tal equívoco. Se uma pequena mudança em $A$ grande arte merece comentários de Rubem Fonseca, pode-se imaginar o efeito ao saber o título que recebeu Agosto em francês: Un été brésilien [Um verão brasileiro]! 


\section{Considerações finais}


Antes de tornar-se o romancista internacionalmente conhecido que é hoje, Rubem Fonseca foi um dos mais produtivos contistas brasileiros das décadas de 1960-1970, durante o regime militar, no Brasil. Seu estilo mordaz foi sua arma para enfrentar a ditadura, subvertendo a linguagem e desafiando a literatura dita elevada. Embora esse tenha sido provavelmente um dos motivos que levaram os franceses a se interessarem por sua literatura nos anos 1970, foi antes como literatura de entretenimento que sua obra achou espaço para ser traduzida e publicada na França, sobretudo seus romances, a partir dos anos 1980.

A crítica especializada, como observado no Capítulo I, explora tanto a vertente ideológica, social dos textos fonsequianos quanto a tendência ao "polar", muitas vezes considerada mais literatura de entretenimento do que experimento da poética pós-moderna. A crítica francesa, no entanto, recebe bem o autor brasileiro e estimula o leitor a descobrir a obra de Rubem Fonseca.

Os critérios de seleção do material fonsequiano a ser traduzido e publicado em francês obedecem a estratégias ofensivas, criando a demanda e contentando o mercado especializado. Pode-se observar que, nesse sentido, os projetos editoriais contemplaram a tradução e a publicação de romances do autor em detrimento de seus contos, apesar do esforço da tradutora Marguerite Wünscher em acoplar Feliz ano novo ao romance $O$ caso Morel.

Conforme apreciação de testemunhos, a tradução de Bonne et heureuse année / Le cas Morel foi fruto de grande pesquisa e de uma vontade editorial, correspondendo a um projeto editorial que não vingou. As traduções de Du grand art a Le sauvage de l'opéra parecem corresponder a uma outra estratégia mercadológica, ligada à valorização do romance como gênero, e mais precisamente à exploração de literatura considerada de entretenimento.

A análise do material paratextual, no Capítulo II, foi também bastante reveladora do posicionamento das editoras, sobretudo da Grasset, que buscou transmitir na parte visual o exotismo brasileiro e, nos textos de acompanhamento, a importância de Rubem Fonseca no contexto brasileiro, porém, não sem explorar ao máximo a tendência a um certo biografismo, e muitas vezes reforçando o apelo ao gênero de romance policial. 
Nesse sentido, uma conseqüência flagrante da publicação de Fonseca na França foi abrir o caminho a seus discípulos, como Patrícia Melo e Luiz Alfredo Garcia-Roza. A primeira, assim como Fonseca, goza de status privilegiado, pois tanto a crítica quanto sua editora hesitam entre a categoria de romancista policial e crítica social. Essa é a ambigüidade que assegura às obras de Patrícia Melo e Rubem Fonseca a possibilidade de circular entre mãos e sob olhos de leitores com distintas expectativas.

No que concerne à publicação dos contos em antologias, a seleção, mesmo que conduzida por critérios subjetivos, acaba contemplando contos que tratam de temas mais universalizantes do que exóticos, contrariando tendências do mercado editorial francês. Os assuntos desenvolvidos em "O outro", "Gazela", "Relatório de ocorrência em que qualquer semelhança não é mera coincidência", "O balão fantasma" e "Almoço na serra no domingo de carnaval" relacionam-se ao ser humano em geral, suas paixões, suas angústias. Fonseca mostra que todos nós somos de certa forma marginalizados, pois somos de alguma maneira sobreviventes em sociedades cruéis, um mundo multifacetado da poética fonsequiana como bem compreendeu e descreveu Luiz Costa Lima (1981). Os leitores franceses que puderam apreciar esses contos certamente conheceram, como reza a crítica brasileira, o melhor ângulo de Rubem Fonseca, graças ao gosto literário de tradutores e editores, e muitas vezes ao acaso.

No Brasil, Fonseca é freqüentemente criticado por manter uma produtividade constante, suprindo as necessidades dos consumidores e de sua editora. O livro é sem dúvida um veículo tradicional da cultura. Rubem Fonseca participa já há algumas décadas dessa batalha mercadológica, assegurando a presença de escritores brasileiros no exterior.

Estudos de recepção visam esclarecer a maneira pela qual o Brasil participa desse fluxo e de que forma a literatura brasileira é recebida nos países de referência cultural. Este estudo teve por objetivo explorar o tema sem generalizá-lo. O caso de Rubem Fonseca é bastante particular e convida o pesquisador a se questionar se houve evolução histórica na maneira pela qual os franceses viam os brasileiros quando começaram a se interessar por sua 
literatura, e o modo como vêem os brasileiros nas últimas décadas. Alguns elementos, como a publicação eventual dos contos de Fonseca em antologias, indicam que, mesmo lentamente, pode haver mudança na forma de os franceses olharem para os brasileiros, sem o clichê do "bom selvagem" ou do "homem cordial". Em uma época em que o exotismo ganha uma nova face, a da violência, da fome, dos sobreviventes tanto do Primeiro quanto do Terceiro mundos, as narrativas de Fonseca tendem a agradar mais de um tipo de público.

A tradução de literatura envolve muito mais do que os aspectos lingüísticos. O desafio dos tradutores corresponde talvez ao fator mais intransponível em tradução. É a alteridade. É o jeito de um/outro ser, fazer, viver submetido a fatores históricos.

O homem, desde sempre, traduz. Traduz para comunicar suas experiências, seus medos, seus questionamentos, num movimento de dentro (de si) para fora. Traduz também para compreender as experiências, os medos e os questionamentos do OUTRO, num movimento do exterior para sua compreensão interior, de fora para dentro. Uma das motivações do ato tradutório é indubitavelmente a necessidade de se compreender o outro e, dessa forma, vivenciar as experiências do outro. Pela tradução, os homens se identificam com modelos ou os rejeitam. Traduzir é um ato social. E apesar de o homem desde sempre ter praticado o ato tradutório, nunca se traduziu tanto como nos dias de hoje.

Ao contemplar o tradutor de Rubem Fonseca e seu horizonte de expectativa, no Capítulo III, elementos freqüentemente extraliterários definem a maneira pela qual esse tradutor leu o texto e o Brasil e se situou como importante intermediário cultural. O contato com os textos e com os tradutores, por meio de seus depoimentos, mostra que cada texto tem sua história própria.

A primeira tradutora de Rubem Fonseca na França, Marguerite Wünscher, viveu por três anos no Brasil. Não manteve, porém, o contato direto com o autor brasileiro, mas sim por intermédio de Estela dos Santos Abreu, também tradutora. Já o segundo tradutor, Philippe Billé, manteve uma profícua correspondência com Rubem Fonseca e passou apenas um mês e meio no Brasil. Inicia-se neste 
trabalho a apreciação da correspondência entre o autor e o tradutor. Os primeiros passos desse exame confirmam que o acesso do pesquisador à "correspondência entre autor e tradutor, entre criador e re-criador, não tem apenas o mérito de recompor um momento histórico em que se lançam as bases da fortuna literária universal de um texto", mas contribuem igualmente para se "recuperar informações fundamentais para a crítica genética" (Aubert, 2003, p.17). Dessa forma, pode-se ter acesso e se apreciar, por exemplo, o que de fato ocorreu com a transformação do título de $A$ grande arte e Agosto para o francês.

A análise de parte do material textual, por meio do cotejo entre obra original e obra traduzida, auxilia parcialmente a reflexão sobre uma certa forma de se ler tanto a obra de um autor quanto sua cultura, mas não se revela, no caso das traduções de Rubem Fonseca para a língua francesa, totalmente esclarecedora a respeito de sua recepção naquele país. As opções dos tradutores para solucionar "problemas" de ordem lexical, no que se refere às marcas culturais e orais, apontam para tendências que, em diferentes graus, ora reforçam as normas existentes e assimilam a literatura traduzida no universo literário de chegada, adequando a obra a esse sistema, ora incorporam o texto ao sistema, tornando-o mais leve, tirando dele o elemento transgressor, original, presente em sua poética. Essas transformações, que podem ser consideradas pequenas antropofagias tradutórias, transfiguram, alteram a poética narrativa, mas não parecem ser, no caso de Rubem Fonseca, determinantes de sua fortuna, seu sucesso ou fracasso editorial, na França.

Embora tenha sido realizado o levantamento de alguns pontos problemáticos na tradução dos textos para a língua francesa, não cabe aqui mensurar a qualidade dessa tradução, mas sim lançar alguns questionamentos. Os mal-entendidos apontados não chegam a corromper o texto de chegada arriscando a boa recepção literária. As opções dos tradutores não comprometem a compreensão do texto pelo público francês, mas são facilitadoras de seu entendimento. Nesse sentido, há uma tendência para a eufemização em diferentes graus. O conto "Feliz ano novo", por exemplo, significou, em 1975, no 
Brasil, um grito de protesto e de revelação de que a violência não é gerada pela pobreza em si, mas sim pelas desigualdades sociais.

Se os leitores franceses não conseguem desfrutar da obra fonsequiana em sua plenitude, por que traduzir Rubem Fonseca para a língua francesa? Vislumbram-se aqui algumas razões para que os franceses continuem a traduzir e a ler Rubem Fonseca, que se complementam: uma afinidade ideológica característica do povo francês, inspirado pelos ideais revolucionários que até hoje norteiam a mentalidade desse povo, destaca-se o interesse pela produção de povos em momentos de repressão e de cunho social; a curiosidade diante de um tipo de "exotismo" que representa e sempre representou o Brasil no imaginário europeu e que hoje se reveste de elementos mais universalizantes; e, finalmente, o que define a literatura de Rubem Fonseca em "tempos de paz": um bom escritor de romance policial, se assim desejar o leitor francês, já que a França possui um grande interesse e uma tradição nesse tipo de literatura, e que, segundo José Paulo Paes (1990), é lendo literatura considerada de "entretenimento" que se conduz o leitor a outras leituras.

\section{Bibliografia}

\section{Rubem Fonseca}




\section{Obras em língua portuguesa}

FONSECA, J. R. O homem de fevereiro ou março. Rio de Janeiro: Artenova, 1973. . Feliz ano novo. Rio de Janeiro: Artenova, 1975. . Os prisioneiros. Rio de Janeiro: Codecri, 1978. . Vastas emoções e pensamentos imperfeitos. São Paulo: Companhia das Letras, 1989a. . Agosto. São Paulo: Companhia das Letras, 1991a. . Romance negro e outras histórias. São Paulo: Companhia das Letras, 1992.

. A grande arte. São Paulo: Companhia das Letras, 1994a.

. Contos reunidos. Org. Boris Schnaiderman. São Paulo: Companhia das Letras, 1994b.

. O outro. In: Contos para um natal brasileiro. Rio de Janeiro: RelumeDumará: IBASE, 1996.

. Histórias de amor. São Paulo: Companhia das Letras, 1997a.

. Do meio do mundo prostituto só amores guardei ao meu charuto. São Paulo: Companhia das Letras, 1997b.

. Feliz ano novo. São Paulo: Companhia das Letras, 1999a.

. O selvagem da ópera. São Paulo: Companhia das Letras, 1999b.

. O cobrador. São Paulo: Companhia das Letras, 1999c.

. O doente Molière. São Paulo: Companhia das Letras, 2000.

. A coleira do cão. São Paulo: Companhia das Letras, 2001a.

. Lúcia McCartney. São Paulo: Companhia das Letras, 2001b.

. O buraco na parede. São Paulo: Companhia das Letras, 2001c.

. Confraria dos espadas. São Paulo: Companhia das Letras, 2002a.

. Bufo \& Spallanzani. São Paulo: Companhia das Letras, 2002b.

. Pequenas criaturas. São Paulo: Companhia das Letras, 2002c.

. Secreções, excreções e desatinos. São Paulo: Companhia das Letras, 2002d.

. O caso Morel. Rio de Janeiro: O Globo, 2003a. 
. Diário de um fescenino. São Paulo: Companhia das Letras, 2003b.

\section{Rubem Fonseca}

\section{Obras traduzidas para a língua francesa}

FONSECA, J. R. Le cas Morel suivi de Bonne et heureuse année. Trad. Marguerite Wünscher. Paris: Flammarion, 1979.

. Du grand art. Trad. Philippe Billé. Paris: Grasset, 1986.

. Bufo \& Spallanzani. Trad. Philippe Billé. Paris: Grasset, 1989b.

- Vastes émotions et pensées imparfaites. Trad. Philippe Billé. Paris:

Grasset, 1990.

. Un été brésilien. Trad. Philippe Billé. Paris: Grasset, 1993a.

. Du grand art. Trad. Philippe Billé. Paris: Librairie Générale

Française/Grasset, 1995b. (Collection Le Livre de Poche, n.13694)

. Un été brésilien. Trad. Philippe Billé. Paris: Librairie Générale

Française/Grasset, 1996. (Collection Le Livre de Poche, n.13969)

. Le sauvage de l'opéra. Trad. Philippe Billé. Paris: Grasset, 1998a.

\section{Rubem Fonseca}

\section{Antologias em tradução para a língua francesa}

FONSECA, J. R. L'autre. Trad. Daisy da Conceição Elísio \& Mariangela dos Santos Paulo. Europe, Revue littéraire Mensuelle. Paris: Europe, 1982.

. La force humaine. In: Dérives. Trad. Pierre Germain Clemens. Montréal: Nouvelles Brésiliennes, 1983.

. Gazelle. In: Anthologie de la nouvelle latino-américaine. Trad. Lyne Strouc. Paris: Delfond, 1991b.

. Compte rendu de circonstances où toute ressemblance n'est pas pure coïncidence. In: LÉON, O. G. de (Org.) Menaces - Anthologie de la nouvelle noire 
et policière latino-américaine. Trad. Jean-Claude Vignol. Nantes: L'Atalante, 1993b.

. L'autre. In: Contes de Noël brésiliens. Trad. Jacques Thiériot. Paris: Albin Michel, 1997c.

. Le ballon fantôme. In: Des nouvelles du Brésil. Trad. Philippe Billé. Paris:

Editions Métailié, 1998b.

. Confeitaria Colombo. In : Le goût de Rio de Janeiro. Trad. Philippe Billé.

Paris : Mercure de France, 2004.

. Déjeuner à la montagne un dimanche de carnaval. Trad. Florent Kohler.

In: Europe, Revue littéraire Mensuelle. Paris: Europe, 2005.

\section{Rubem Fonseca}

Fortuna crítica na França

ARMEL, A. Rubem Fonseca, amour et douleur. Magazine Littéraire, Paris, mars 1998.

CHARPENTIER, B. Mandrake à Rio. Figaro Litéraire, Paris, 16 juin 1986.

CORTANZE, G. De. Le Brésil sans folklore. Magazin Littéraire, Paris, avril 1979.

DURAND, D. Glouglous baroques à Rio. Le Canard Enchaîné, Paris 5 avril 1989.

FOGEL, J.-F. Meurtre à deux visages: Bufo \& Spallanzani. Le Point, Paris, 23 janvier 1989.

FONSECA, R. Pourquoi écrivez-vous? Libération. Numéro hors série - mars 1985, p.25.

KECHICHIAN, P. Le chaos Rubem Fonseca. Le Monde, Paris, 27 janvier 1989.

LORIOT, N. Du Grand Art, par Rubem Fonseca. L'Express, Paris, 1 août 1986.

NOUEL, E. e J.-C. R. Polar sous les tropiques. Le Monde des Livres, Paris, 20 mars 1998.

NOURRY, P. Fonseca: les bas-fonds de Rio. Le Point, Paris, 23 juin 1986.

RAILLARD, A. Le Brésil des années 70. La Quinzaine Littéraire, Paris, 1-15 juin 1979. 
REROLLE, R. Un livret sans musique. Le Monde, Paris, 20 mars 1998.

\section{Fundamentação teórica}

\section{Tradução geral - Tradução e Literatura Comparada}

ALVAREZ, R.; VIDAL, M. C.-A. Translation Power Subversion. Topics in Translation, Great Britain, n.8, 1996.

ALVES, I. C. Modalidades de tradução: uma avaliação de modelo proposto por Vinay e Darbelnet. São Paulo, 1983. Dissertação (Mestrado) - Faculdade de Letras, Pontifícia Universidade Católica.

AUBERT, F. H. Etapas do ato tradutório. Tradução e Comunicação, São Paulo, V.1, 1981.

- Descrição e quantificação de dados em tradutologia. Tradução e Comunicação, São Paulo, v.4, 1984.

- A tradução literal: impossibilidade, inadequação ou meta? Ilha do Desterro, Florianópolis, 1987.

. Prefácio. In: BUSSOLOTTI, M. A. F. M. (Org. e notas) João Guimarães Rosa, correspondência com seu tradutor alemão Curt Meyer-Clason (1958-1967). Trad. Erlon José Paschoal. Rio de Janeiro: Nova Fronteira, Academia Brasileira de Letras; Belo Horizonte: Editora da UFMG, 2003.

- Translational contamination of target languages: a risk to language integrity? An introductory essay. Tradução \& Comunicação, Revista Brasileira de Tradutores, São Paulo, n.13, 71-81, maio 2004.

BALLARD, M. Ambigüité et traduction. In: CUERTIS, J.-L. La traduction plurielle. Lille: Presses universitaires de Lille, 1990. . (Org.) Oralité et traduction. Arras: Artois Presses Université, 2001.

BARBOSA, H. G. Procedimentos técnicos da tradução: uma nova proposta. Campinas: Pontes, 1990.

BASSNETT, S., LEFEVERE, A. Constructing Cultures on Literary Translation. Topics in Translation, Great Britain, n.11, 1998. 
BEJNAMIN, W. A tarefa - renúncia do tradutor. Trad Susana K. Lages. In: HEIDERMAN, W. (Org.) Clássicos da teoria da tradução. Florianópolis: UFSC, 2001. p.188-215.

BERMAN, A. La traduction et la lettre ou L'Auberge du lointain. Paris: Seuil, 1995a.

. Pour une critique des traductions: John Donne. Paris: Gallimard, 1995b.

- A prova do estrangeiro: cultura e tradução na Alemanha romântica.

Trad. Maria Emília Pereira Chanut. Bauru: Edusc, 2002.

BRUNEL, P.; PICHOIS, C.; ROUSSEAU, A. M. Que é literatura comparada? São Paulo: Perspectiva, 1990.

CAMARGO, D. de C. Contribuição para uma tipologia da tradução: as modalidades de tradução no texto literário. São Paulo, 1993. Tese (Doutoramento) - Faculdade de Filosofia, Letras e Ciências Humanas, Universidade de São Paulo. CANDIDO, A. A. Literatura comparada. In: . Recortes. São Paulo: Companhia das Letras, 1993. p.211-5.

CARELLI, M. Culturas cruzadas. Intercâmbios culturais entre França e Brasil. Trad. Nícia A. Bonatti. Campinas; Papirus, 1994.

CARVAlHAL, T. F. Literatura comparada. São Paulo: Ática, 1992. (Série Princípios)

1993.

. A tradução literária. Organon/UFRGS, Instituto de Letras, v.7, n.20, CATFORD, J. C. A Linguistic Theory of Translation. London: Oxford University Press, 1965.

. Uma teoria lingüística da tradução. Trad. Centro Especializado de Tradutores da Pontifícia Universidade Católica de Campinas. São Paulo: Cultrix/Universidade Católica de Campinas, 1980.

COUTINHO, E. F., CARVALHAL, T. F. (Org.) Literatura comparada: textos fundadores. Rio de Janeiro: Rocco, 1994.

CHEVREL, Y. La littérature comparée. Paris: PUF, 1995.

DARIN, L. Translation modalities in the comparison of English and Portuguese Analysis of excerpts taken from C. Castañeda's novel "The Teachings of D. Juan" or "A Erva-do-Diabo". Exeter, 1986. Dissertação (Mestrado) - University of Exerter. 
DERRIDA, J. Torres de Babel. Trad. Junia Barreto. Belo Horizonte: Editora da UFMG, 2002.

EVEN-ZOHAR, I. The position of translated literatura within the literary polysystem. In: HOLMES, J. S.; LAMBERT, J.; BROECK, R. V. D. (Ed.) Literature and Translation: New Perspectives in Literary Studies. Leuven: ACCO (Academic Publishing Company), 1978.

. Universals of literary contacts. In: COPPIETERS, F. ; GOYVAERTS, D. L. (Ed.) Functional Studies in Language and Literature. Ghent, Antwerp \& Brussels: E. Story-Scientia P.V.B.A. Scientific Publishers, 1978.

. The textemic status of signs in a literary text and its translation. In:

CHATMAN, S.; ECO, H.; KLINSBENBERG, J.-M. (Ed.) A Semiotic Landscape:

Procedings of the First Congress of the International Association for Semiotic Studies. Mila, June. 1974/ Panorama Sémiotique: Actes du premier congrès de l'Association Internationale de Sémiotique. Milan, Juin 1974. The Hague, Paris, New York: Mouton Publishers, 1979. (Approches to Semiotics - 29)

. Translation theory today. Poetics today. The Porter Institute for Poetics and Semiotics - Tel Aviv University, v.2, n.4, p.1-7, summer/autumn 1982.

DESLILE, J.; WOODSWORTH, J. (Org.) Os tradutores na história. Trad. Sérgio Bath. São Paulo: Ática, 1998. (Col. Múltiplas Escritas)

GENETTE, G. Palimpsestes. Paris: Seuil, 1982.

. Seuils. Paris: Seuil, 1987.

GENTZLER, E. Contemporary Translation Theories. Translation Studies. USA, Canada: Routledge, 1993.

GRAF, M. (Org.) L'écrivain et son traducteur: en Suisse et en Europe. CarougeGenève: Zoé, 1998.

GUIMARÃES, E. A articulação do texto. São Paulo: Ática, 1997.

HERMANS, T. Translatyion in Systems: Descriptive and Systemic Approaches Explained. St. Jerome: Manchester, 1999.

JAKOBSON, R. Aspectos lingüísticos da tradução. In: Lingüística e comunicação. Trad. Izidoro Blikstein e José Paulo Paes. São Paulo: Cultrix, 1972. 
LADMIRAL, J. R. A tradução e seus problemas. Lisboa: Edições 70, 1980. (Col. Signos 29)

. La communication interculturelle. Paris: Armand Colin, 1995. . Traduire: Théorèmes pour la traduction. Paris: Gallimard, 1994.

LARANJEIRA, M. Poética da tradução: do sentido à significância. São Paulo: Editora da Universidade de São Paulo, 1993. (Criação e Crítica, 2)

LARBAUD, V. Sob a invocação de São Jerônimo: ensaios sobre a arte e as técnicas de tradução. Trad. Joana Angélica d'Avila Melo. Trad. do grego e do latim João Ângelo Oliva. São Paulo: Mandarim, 2001.

LEFEVERE, A. Translation, Rewriting, and the Manipulation of Literary Fame. Translation Studies. USA, Canada: Routledge, 1992.

LEENHARDT, J.; JÓZSA, P. Lire la lecture. Essai de sociologie de la lecture. Paris: Le Sycomore, 1982.

MESCHONNIC, H. Pour la poétique. Paris : Gallimard, 1970. v.1, . Pour la poétique. Paris : Gallimard, 1973. v.2 e v.3.

MILTON, J. A tradução literária e a literatura comparada. In: Anais do $2^{\circ}$ Congresso ABRALIC: Literatura e Memória Cultural. Belo Horizonte: ABRALIC, 1991. p.57-61.

. O poder da tradução. São Paulo: Ars Poetica, 1993. (Col. Ensaio, 5) . Tradução: teoria e prática. São Paulo: Martins Fontes, 1998.

. Tradução e a teoria dos polissistemas. Miscelânea - Revista de PósGraduação em Letras: Teoria Literária, Literatura Comparada e Literaturas de Língua Portuguesa (Assis), v.3, p.175-81, 1998.

MOUNIN, G. Os problemas teóricos da tradução. Trad. Heloysa de Lima Dantas. São Paulo: Cultrix, 1975. . Les belles infidèles. Lille: Presses Universitaires de Lille, 1994.

NEWMARK, P. Approaches to translation. Oxford: Pergamon, 1984. . A Textbook of Translation. New York: Prentice-Hall International, 1988. NIDA, E. A. ; TIBER, C. R. Theory and Practice of Translation. Leiden: United Bible Societies, 1982. 
NIDA, E. A. Toward a Science of Translating: With Special Reference to Principles and Procedures Involved in Bible Translating. Leiden: E.J. Brill, 1964.

NITRINI, S. M. Literatura comparada. São Paulo: Edusp, 1997.

. (Org.) Aquém e além mar, relações culturais: Brasil e França. São Paulo: Hucitec, 2000.

PAGEAUX, D.-H. La littérature générale comparée. Paris: Armand Colin, 1994. (Coll. Cursus)

PEREIRA, H. B. C. Poesia brasileira na belle époque francesa. In: PEREIRA, H. B. C.; ATIK, M. L. G. Intermediações culturais: Brasil-França. São Paulo: Scortecci, 2005. p.85-97.

RIVAS, P. Encontro entre literaturas: França, Portugal, Brasil. São Paulo: Hucitec, 1995.

. Diálogos interculturais. São Paulo: Hucitec, 2005.

ROBINSON, D. Construindo o tradutor. Trad. Jussara Simões. Bauru: Edusc, 2002.

RODRIGUES, C. C. Tradução e diferença. São Paulo: Editora Unesp, 2000.

SCHLEIERMACHER, F. Sobre os diferentes métodos de tradução. Trad. Margarete von Mühlen Poll. In: HEIDERMAN, W. (Org.) Clássicos da teoria da tradução. Florianópolis: UFSC, 2001. p.26-85.

SILVA, M. G. G. V. As modalidades de tradução aplicadas ao conto "O cobrador". São Paulo, 1992. Dissertação (Mestrado) - Faculdade de Filosofia, Letras e Ciências Humanas, Universidade de São Paulo.

TELES, G. M. Retórica do silêncio I - Teoria e prática do texto literário. Rio de Janeiro: José Olympio, 1989.

TOURY, G. In Search of A Theory of Translation. The Porter Institute for Poetics and Semiotics - Tel Aviv: Tel Aviv University, 1980.

. Descriptive Translation Studies and Beyond. Amsterdam/Philadelphia:

John Benjamins Publishing, 1995.

VENUTI, L. (Org.) Rethinking translation: Discourse, Subjectivity, Ideoloy. USA, Canada: Routledge, 1992. 
. The translator's invisibility: A History of translation. London: Routledge, 1995.

. Escândalos da tradução: por uma ética da diferença. Trad. Laureano Pelegrin, Lucinéia Marcelino Villela, Marileide Dias Esquerda e Valéria Biondo; revisão técnica Stella Tagnin. Bauru: Edusc, 2002.

VINAY, J.-P. ; DARBELNET, J.-L. Stylistique comparée du français et de l'anglais: Méthode de traduction. Paris: Didier, 1977.

\section{Bibliografia geral}

ABIGRAF. Revista da Associação Brasileira da Indústria Gráfica. Edição Especial "Paris, França: Salão do Livro' 98". Fundação Biblioteca Nacional/Departamento Nacional do Livro. Março, 1998.

ABREU, E. dos S. Ouvrages brésiliens traduits en France/Livros brasileiros traduzidos na França - $2^{\text {ème }}$ édition augmentée. Bureau du Livre. Rio de Janeiro: Consulat Général de France, 1990.

. Ouvrages brésiliens traduits em France - Livros brasileiros traduzidos na

França. 5.ed. atualizada. Rio de Janeiro: Edições Biblioteca Nacional, 2004.

BAKHTIN, M. Marxismo e filosofia da linguagem. 2.ed. São Paulo: Hucitec, 1981. . Questões de literatura e de estética (A teoria do romance). São Paulo: Editora Unesp/Hucitec, 1993.

. Estética da criação verbal. São Paulo: Martins Fontes, 2000.

BILLÉ, P. Poèmes listes. Bordeaux: Pierre Mainard, 2001. (Coll. Prose v.1)

. RIO MÊME - souvenirs d'un voyage au Brésil. Bordeaux: Pierre Mainard, 2002. (Coll. Prose v.4)

BOURJEA, S. Une littérature sur les tropiques. Revue Mensuelle fondée em 1923. Paris, n.640-1, p.3-9, Aôut.-Sept., 1982.

CALVET, J.-L. L'argot en 20 leçons, ou comment ne pas en perdre son français. Paris: Payot/Rivages, 1993. . L'Argot. Paris: PUF, 1994. (Coll. "Que sais-je" 700) 
CANDIDO, A. Formação da literatura brasileira: momentos decisivos. São Paulo: Livraria Martins Editora, 1959. 2v.

CASANOVA, P. La republique mondiale des lettres. Paris : Seuil, 1999.

CHEREM, L.P. Um olhar estrangeiro sobre a obra de Clarice Lispector: leitura e recepção da autora na França e no Canadá (Quebec). São Paulo, 2003. Dissertação (Mestrado) - Faculdade de Filosofia, Letras e Ciências Humanas, Universidade de São Paulo.

COELHO, M. Les bons et les méchants. Revue Mensuelle fondée em 1923. Paris, n.919-20, p.45-63, Nov.-Déc., 2005

COSTA, W. Un roman brésilien en français. Questions de traduction à propos de Grande sertão: veredas de J. Guimarães Rosa. Leuven, 1980. Dissertação (Mestrado) - Katholieke Universiteit van Leuven.

COUTINHO, A. O erotismo na literatura (O caso Rubem Fonseca). Rio de Janeiro: Cátedra, 1979.

CUNHA, T. D. C. da. As obras de Mário de Andrade traduzidas na França: história, concepção e crítica. Rio de Janeiro, 1999. Dissertação (Mestrado) - Faculdade de Letras, Universidade Federal do Rio de Janeiro.

DERRIDA, J. Anne Dufourmantelle convida Jacques Derrida a falar Da Hospitalidade. Trad. Antonio Romane; revisão técnica Paulo Ottoni. São Paulo: Escuta, 2003.

DÉSIRAT, C. I.; TRISTAN, H. La Langue française au XXe siècle. Paris: Bordas, 1976. (Coll. Études série langue française dirigée par J. Batany)

ECO, U. Lector in fabula. São Paulo: Perspectiva, 1979.

ESCARPIT, R. Le littéraire et le social. Paris: Flammarion, 1970.

EUROPE. Revue Mensuelle fondée em 1923. Paris, n.599, Mars 1979.

. Revue Mensuelle fondée em 1923. Paris, n.640-1, Août-Sept. 1982.

. Revue Mensuelle fondée em 1923. Paris, n.919-20, Nov.-Déc., 2005.

FARIA, A. Literatura de subtração - A experiência urbana na ficção contemporânea. Rio de Janeiro: Papel \& Virtual, 1999.

FIGUEIREDO, V. L. F. de. Os crimes do texto - Rubem Fonseca e a ficção contemporânea. Belo Horizonte: Editora da UFMG, 2003. 
FIORIN, J. L. Linguagem e ideologia. São Paulo: Ática, 2003.

GADET, F. Le Français populaire. Paris: PUF, 1992. (Coll. "Que Sais-Je?” 1172)

GANCHO, C. V. Discurso. In: __ Como analisar narrativas. São Paulo: Ática, 1993. p.33-40.

GARDIN, B. ; MARCELLESI, J. B. Introduction à la sociolinguistique, la linguistique sociale. Paris: Larousse, 1974.

GASPARI, E. A ditadura envergonhada. São Paulo: Companhia das Letras, 2002a.

. A ditadura escancarada. São Paulo: Companhia das Letras, 2002b. . A ditadura derrotada. São Paulo: Companhia das Letras, 2003.

GOMES, R. C. Todas as cidades, a cidade - literatura e experiência urbana. Rio de Janeiro: Rocco, 1994.

ISER, W. O ato da leitura. Uma teoria do efeito estético. Trad. Der Akt des Lesens. São Paulo: Editora 34, 1996. v.1.

JAUSS, H. R. A história da literatura como provocação à teoria literária. Trad. Sérgio Tellaroli. São Paulo: Ática, 1994.

LE CANARD ENCHAINÉ. Les dossiers du Canard. Tant qu'il y aura des tomes... Enquête sur le petit monde des livres et les nouveaux pontes de l'édition. Paris, oct. 2004.

JOHNSON, C. Derrida: a cena da escritura. Trad. Raul Fiker. São Paulo: Editora Unesp, 2001.

KIRSCH, G. F Poética da tradução e recepção estética: Nove novena na França e na Alemanha. São Paulo, 1998. Tese (Doutorado) - Faculdade de Filosofia, Letras e Ciências Humanas, Universidade de São Paulo.

LEITE, L. C. M. O foco narrativo. São Paulo: Ática, 1985.

LIMA, L. C. O cão pop e a alegoria cobradora. In: . Dispersa demanda. Rio de Janeiro: Francisco Alves, 1981.

. (Org.) A literatura e o leitor. Textos da estética da recepção. Rio de Janeiro: Paz e Terra, 2002.

MAINGUENEAU, D. Análise de textos de comunicação. São Paulo: Cortez, 2001. 
MORAES, E. R. Topographie du risque. Revue Mensuelle fondée em 1923. Paris, n.919-20, p.102-12, Nov.-Déc., 2005

MULLER, B. Le français aujourd'hui. Paris: Klincksieck, 1985.

OLIVEIRA, M. T. I. de. L'oeuvre de Jorge Amado en France: réception critique. Grenoble, 1977. Tese (Doutorado) - Université de Grenoble.

PAES, J. P. Por uma literatura brasileira de entretenimento (ou: O mordomo não é o único culpado). In: . A aventura literária. Ensaios sobre ficção e ficções. São Paulo: Companhia das Letras, 1990.

PINTO, M. da C. Panorama de la prose brésilienne. Revue Mensuelle fondée em 1923. Paris, n.919-20, p.29-44, Nov.-Déc., 2005.

PEREIRA, M. A. Signos em trânsito: A grande arte de Rubem Fonseca. In: PEREIRA, M. A.; SANTOS, L. B. (Org.) Seis escritores latino-americanos contemporâneos. Belo Horizonte: Atlântica, 1999.

. No fio do texto - A obra de Rubem Fonseca. Belo Horizonte: Faculdade de Letras da UFMG, 2000.

PETROV, P. O realismo na ficção de José Cardoso Pires e Rubem Fonseca. Lisboa: Algés, 2000.

PRETI, D. A gíria e outros temas. São Paulo: Edusp, 1984.

. (Org.) Análise de textos orais. São Paulo: Humanitas, 1993.

. Usos e abusos de algumas palavras bem brasileiras. Jornal da USP. São Paulo, 1995. p.14.

. A gíria na cidade grande. Revista da Biblioteca Mário de Andrade, n.54, p.139-43, jan./dez. 1996.

- Oralidade e narração literária. Revista da ANPOLL, n.4, p.81-96, jan./jun. 1998a.

. A gíria na sociedade contemporânea. In: VALENTE, A. C. (Org.) Língua, lingüística e literatura - uma integração para o ensino. Rio de Janeiro: Eduerj, 1998b. p.119-27.

- Transformações do fenômeno sociolingüístico da gíria. Revista da ANPOLL, n.9, p.213-26, jul./dez. 2000a. 
- A gíria na língua falada e na escrita: uma longa história de preconceito social. In: . (Org.) Fala e escrita em questão. São Paulo: Humanitas, FFLCH/USP, 2000b. p.241-57.

. Dino Preti e seus temas: oralidade, literatura, mídia, ensino. São Paulo: Cortez, 2001.

REIS, C.; LOPES, A. C. M. Dicionário de teoria da narrativa. São Paulo: Ática, 1988.

RIAUDEL, M. Le périple transatlanque. Le Monde, Paris, 20 mars1998.

RIBEIRO, G. P. O olho e o discurso - Uma leitura de Rubem Fonseca. Juiz de Fora: Universidade Federal de Juiz de Fora, 2000.

ROCHA, J. C. de C. Le dialectique de la "marginalité" et la violence dnas la culture brésilienne. Revue Mensuelle fondée em 1923. Paris, n.919-20, p.64-73, Nov.Déc., 2005.

ROUAYRENC, C. Les gros mots. Paris : PUF, 1996. (Coll. "Que Sais-Je?" 1597)

SILVA, D. da. Um novo modo de narrar. São Paulo: Livraria Cultura, 1979.

. O caso Rubem Fonseca - Violência e erotismo em Feliz ano novo. São Paulo: Alfa-Ômega, 1983.

. Nos bastidores da censura - Sexualidade, literatura e repressão pós-64.

São Paulo: Estação Liberdade, 1984.

. Rubem Fonseca. Rio de Janeiro: Relume-Dumará/RioArte, 1996. (Col.

Perfis do Rio)

SILVERMAN, M. Rubem Fonseca. In: Moderna ficção brasileira 2. Rio de Janeiro: Civilização Brasileira/MEC, 1981.

TORRES, M.-H. C. Variations sur l'étranger dans les lettres: cent ans de traductions françaises des lettres brésiliennes. Arras: Artois Presses Université, 2004.

STAUT, L. M. V. Duas traduções francesas de Memórias póstumas de Brás Cubas: por uma estilística da tradução. São Paulo, 1982. Dissertação (Mestrado) Faculdade de Filosofia, Letras e Ciências Humanas, Universidade de São Paulo. 
- Recepção da obra machadiana na França: um estudo crítico-estilístico das traduções de quatro romances. São Paulo, 1991. Tese (Doutorado) Faculdade de Filosofia, Letras e Ciências Humanas, Universidade de São Paulo.

VENTURA, Z. 1968 - o ano que não terminou. Rio de Janeiro: Nova Fronteira, 1988.

VIDAL, A. J. Roteiro para um narrador: uma leitura dos contos de Rubem Fonseca. São Paulo: Ateliê Editorial, 2000.

VIEGAS, A. C. C. Literatura e consumo: o caso Rubem Fonseca. Rio de Janeiro: Ágora da llha, 2002

VILLON, F. Le Testament / O Testamento. In: LEITE, S.U. (Tradução, organização e notas). François Villon - poesia. São Paulo: Edusp, 2000.

ZAND, N. Les brésiliens arrivent... Le Monde, 33 mars 1987, p.14

ZILBERMAN, R. Estética da recepção e história da literatura. São Paulo: Ática, 1989.

\section{Dicionários}

CADEREC, F. N'ayons pas peur des mots: dicitionnaire du français argotique et populaire. Paris: Larousse, 1989.

EDOUARD, R. Dictionnaires des injures: les 9.300 gros mots de la langue française. Paris: Tchou, 1979.

GREVISSE, M. Le bon usage. Paris, Gembloux: Duculot, 1980.

GURGEL, J. B. S. e. Dicionário de gíria - Modismo lingüístico, o equipamento falado do brasileiro. Brasília: JB Serra e Gurgel, 1990.

MAUBOURGUET, P. (dir. ed.) Le Petit Larousse illustré en couleurs - Dictionnaire encyclopédique. Paris: Larousse, 1995.

MERLE, P. L'argus des mots. Montréal: Éditions de l'Archipel, 1997.

SOUTO MAIOR, M. Dicionário do palavrão e termos afins. 3.ed. Recife: Guararapes, 1980.

XATARA, C. M. Dicionário de provérbios, idiotismos e palavrões: francêsportuguês / português-francês / Claudia Xatara, Wanda Leonardo de Oliveira. São Paulo: Cultura, 2002. 


\section{ANEXOS}

Considerou-se oportuno fazer constar deste

trabalho parte do material coletado e analisado durante a pesquisa. Optou-se por incluir os textos traduzidos e publicados em antologias e coletâneas, repertoriados na segunda parte do Capítulo III. 


\section{ANEXOS}

\section{Traduções em antologias e coletâneas}

1 - Três versões de "L'autre" I "O outro"

2 - "Gazelle"

3 - "Compte rendu de circonstances où toute ressemblance n'est pas pure coïncidence"

4 - "Le ballon fantôme"

5 - "Déjeuner à la montagne un dimanche de carnaval" 